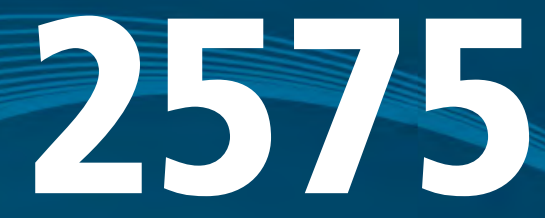

\title{
COMPRAS PÚBLICAS CENTRALIZADAS EM SITUAÇÕES DE EMERGÊNCIA E CALAMIDADE PÚBLICA
}

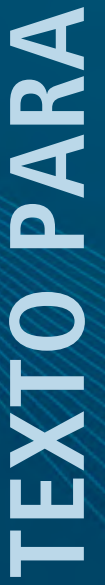

\section{Eduardo P. S. Fiuza Felippe Vilaça Loureiro Santos Virginia Bracarense Lopes Bernardo Abreu de Medeiros \\ Franklin Brasil Santos}





\section{TEXTO PARA DISCUSSÃO}

Brasília, agosto de 2020

\section{COMPRAS PÚBLICAS CENTRALIZADAS EMM SITUAÇÕES DE EMERGÊNCIIA E CALAMIDADE PÚBLICA ${ }^{1}$}

Eduardo P. S. Fiuza ${ }^{2}$

Felippe Vilaça Loureiro Santos ${ }^{3}$

Virginia Bracarense Lopes ${ }^{4}$

Bernardo Abreu de Medeiros ${ }^{5}$

Franklin Brasil Santos ${ }^{6}$

1. Este Texto para Discussão é a versão completa do trabalho que foi sumarizado na Nota Técnica de Fiuza et al. (2020), recém-publicada. Agradecemos a colaboração de Lucas Benevides e equipe, a valiosa assistência de Nicolas Monteiro da Silva e a excelente revisão e comentários de André Rauen, decisivos para o aperfeiçoamento do texto. A todos eximimos de responsabilidade pelos erros remanescentes, que são exclusivamente nossos. As opiniões aqui exaradas não são necessariamente endossadas pelos nossos superiores e são de nossa inteira responsabilidade.

2. Técnico de planejamento e pesquisa na Diretoria de Estudos e Políticas Setoriais de Inovação e Infraestrutura (Diset) do Ipea. 3. Técnico em assuntos educacionais da Defensoria Pública da União (DPU), atualmente cedido como chefe de serviço de compras e contratos na Empresa Brasileira de Serviços Hospitalares (Ebserh).

4. Especialista em políticas públicas e gestão governamental do Ministério da Economia (ME), atualmente cedida como assessora na Secretaria de Estado de Planejamento e Gestão (Seplag) de Minas Gerais.

5. Técnico de planejamento e pesquisa na Diretoria de Estudos e Políticas do Estado, das Instituições e da Democracia (Diest)//pea.

6. Auditor da Controladoria-Geral da União (CGU). 


\section{Governo Federal \\ Ministério da Economia \\ Ministro Paulo Guedes}

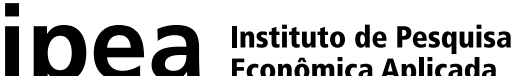 Econômica Aplicada}

Fundação pública vinculada ao Ministério da Economia, o Ipea fornece suporte técnico e institucional às ações governamentais - possibilitando a formulação de inúmeras políticas públicas e programas de desenvolvimento brasileiros - e disponibiliza, para a sociedade, pesquisas e estudos realizados por seus técnicos.

\section{Presidente}

Carlos von Doellinger

Diretor de Desenvolvimento Institucional

Manoel Rodrigues Junior

Diretora de Estudos e Políticas do Estado, das Instituições e da Democracia

Flávia de Holanda Schmidt

\section{Diretor de Estudos e Políticas}

Macroeconômicas

José Ronaldo de Castro Souza Júnior

Diretor de Estudos e Políticas Regionais, Urbanas e Ambientais

Nilo Luiz Saccaro Júnior

Diretor de Estudos e Políticas Setoriais de Inovação e Infraestrutura

André Tortato Rauen

Diretora de Estudos e Políticas Sociais

Lenita Maria Turchi

Diretor de Estudos e Relações Econômicas

e Políticas Internacionais

Ivan Tiago Machado Oliveira

\footnotetext{
Assessora-chefe de Imprensa

e Comunicação

Mylena Fiori

Ouvidoria: http://www.ipea.gov.br/ouvidoria

URL: http://www.ipea.gov.br
}

\section{Texto para Discussão}

Publicação seriada que divulga resultados de estudos e pesquisas em desenvolvimento pelo Ipea com o objetivo de fomentar o debate e oferecer subsídios à formulação e avaliação de políticas públicas.

(C) Instituto de Pesquisa Econômica Aplicada - ipea 2020

Texto para discussão / Instituto de Pesquisa Econômica Aplicada.- Brasília : Rio de Janeiro : Ipea, 1990-

ISSN 1415-4765

1.Brasil. 2.Aspectos Econômicos. 3.Aspectos Sociais. I. Instituto de Pesquisa Econômica Aplicada.

CDD 330.908

As publicações do Ipea estão disponíveis para download gratuito nos formatos PDF (todas) e EPUB (livros e periódicos).

Acesse: http://www.ipea.gov.br/portal/publicacoes

As opiniões emitidas nesta publicação são de exclusiva e inteira responsabilidade dos autores, não exprimindo, necessariamente, o ponto de vista do Instituto de Pesquisa Econômica Aplicada ou do Ministério da Economia.

É permitida a reprodução deste texto e dos dados nele contidos, desde que citada a fonte. Reproduções para fins comerciais são proibidas. 


\section{SUMÁRIO}

SINOPSE

ABSTRACT

1 INTRODUÇÃO 7

2 MOTIVAÇÃO

3 EXPERIÊNCIA INTERNACIONAL DE COMPRAS CONJUNTAS EM GERAL E PARA SAÚDE. .24

4 MEDIDAS DE ENFRENTAMENTO À COVID-19 E A CONSTRUÇÃO DE ARCABOUÇO LEGAL PARA UM NOVO SISTEMA DE COMPRAS COORDENADAS (ACORDO-MARCO).

5 PROPOSTAS PARA O ACORDO-MARCO .52

6 CONSIDERAÇÕES FINAIS. 66

REFERÊNCIAS 69

APÊNDICE A .77

ANEXO A 128 



\section{SINOPSE}

A pandemia da Covid-19 expôs ao mundo a fragilidade dos arranjos institucionais de suprimentos e suscitou a concorrência predatória entre compradores. Neste contexto, a racionalizaçáo da demanda e do uso dos insumos hospitalares e a gestáo centralizada dessas aquisiçôes são estratégias recomendadas, e transpô-las para o cenário brasileiro requer uma apreciação dos desafios e das oportunidades disponíveis para os gestores públicos. As compras colaborativas ou conjuntas são um dos instrumentos mais efetivos para reduzir custos em sistemas de saúde, mas nem a redução de custos deve ser o único objetivo, nem a mera agregação de compras é condição necessária para tal redução. O estado de calamidade pública instituído em fevereiro de 2020 propiciou o rápido surgimento de um direito provisório com vistas a suprir mais rápida e eficazmente as urgentes necessidades de aquisiçôes e contrataçôes, entre as quais destacamos a previsão de utilizaçáo da dispensa de licitaçáo para seleção de fornecedores para atas de registro de preços, a ampliação do uso do regime diferenciado de contrataçóes, o pagamento antecipado de despesas contratadas, e o aumento temporário do limite de valor de dispensa de licitaçáo. Contudo, os avanços podem não ser ainda suficientes e aparenta ser necessário estruturar uma sistemática inovadora para as contrataçôes públicas, como a adoção dos acordos-quadro multifornecedores. Neste trabalho, traçamos três estratégias para viabilizá-los, além de oferecermos três cenários operacionais de implantação, de acordo com a plataforma a ser utilizada (Siasg/Comprasnet ou marketplace ou ambos). A pandemia pode ser uma ótima oportunidade de acelerarmos a convergência para essas compras coordenadas.

Palavras-chave: compras públicas; licitaçóes e contratos; Covid-19; compras coordenadas; comércio eletrônico; registro de preços; acordos-quadro; complexo industrial de saúde.

\section{ABSTRACT}

The Covid-19 pandemic exposed the fragility of institutional supply arrangements to the world and sparked predatory competition among buyers. In this context, the rationalization of demand and use of medical inputs and the centralized management of these acquisitions are recommended strategies, and transposing them to the Brazilian scenario requires an appreciation of the challenges and opportunities available to public managers. Collaborative or joint purchases are one of the most effective instruments to reduce costs in healthcare systems, but neither cost reduction should be the sole objective, nor is the mere aggregation of purchases a necessary condition for such reduction. 
The state of public calamity instituted in February 2020 led to the rapid emergence of a provisional Law with a view to meeting more quickly and effectively the urgent needs for acquisitions and contracts, among which we highlight the provision for the use of bidding waivers in awarding frame contracts (Brazilian Price Registration System), the expansion of the use of the (more flexible) Differentiated Contracting Regime, introduction of advanced payments, and the temporary increase of the upper value threshold of the bidding waiver. However, progress may not be sufficient yet and it appears necessary to structure an innovative system for public procurement, such as the adoption of multi-supplier framework agreements. In this article, we outline three strategies to render them feasible, in addition to offering three operational deployment scenarios, according to the platform to be used (Siasg/Comprasnet or marketplace or both). The pandemic can be a great opportunity to accelerate convergence for these coordinated purchases

Keywords: public procurement; public tenders; Covid-19; pooled procurement; e-commerce; framework agreements; healthcare inputs; medical supplies. 


\section{INTRODUÇÃO}

A pandemia da Covid-19 expôs ao mundo a fragilidade dos arranjos institucionais de suprimentos para os sistemas de saúde mundiais. De uma hora para a outra, o principal fornecedor de equipamentos de proteção individuais (EPIs) do planeta, a China, viu-se com a sua produção paralisada em consequência do próprio esforço de isolamento social decorrente do espalhamento do vírus. Em seguida, a explosão de casos de contaminação ao redor do mundo resultante do alto poder de contágio do vírus, associada a políticas lenientes de contenção, acelerou a demanda pelos EPIs de tal maneira que os países afetados com produção própria suspenderam suas exportaçóes e os não autossuficientes tiveram de disputar entregas, que muitas vezes sofriam mudança de destino ainda prestes a serem embarcadas. ${ }^{1}$ Semelhantes escassezes ocorreram no mercado de respiradores artificiais e higienizantes/saneantes, com diferentes elasticidades de oferta diante dos choques de demanda. ${ }^{2}$

Até dentro de um mesmo país, o grau de fragmentação de seu sistema de saúde pode ensejar comportamentos fraticidas, em que um sistema de saúde público local começa a tomar medidas para proteger seu fornecimento de possíveis interrupçóes e, no limite, prejudicar ou mesmo inviabilizar o fornecimento a outros sistemas públicos ou a privados. ${ }^{3}$ Matéria do jornal $O$ Estado de São Paulo, ${ }^{4}$ de 27 de março de 2020, informava que ao menos seis estados, além de diversas prefeituras, haviam editado atos administrativos para requisitar insumos e produtos, como respiradores, durante a pandemia, levando a União a reagir na Justiça e a defender uma centralização das compras desses produtos.

1. Ver, por exemplo: <https://edition.cnn.com/2020/04/16/politics/ppe-price-costs-rising-economy-personal-protective-equipment/index.html>; <https://www.theguardian.com/world/2020/apr/03/mask-wars-coronavirus-outbidding-demand>; $<$ https://www.cbsnews.com/news/china-ppe-us-buyers-knock-offs-price-gouging/>; e <https://www.ft.com/content/ a94aa917-f5a0-4980-a51a-28576f09410a>.

2. Ver, por exemplo: <https://www.bbc.com/portuguese/internacional-52166245>.

3. Algumas notícias sobre confiscos: <https://blogs.ne10.uol.com.br/jamildo/2020/03/23/bolsonaro-tentou-confiscar-ventiladores-pulmonares-comprados-pelo-recife-trf5-barrou-iniciativa>; <https://exame.abril.com.br/negocios/justica-manda-prefeitura-de-cotia-devolver-35-respiradores-confiscados/>; e

<https://valor.globo.com/empresas/noticia/2020/03/30/governos-disputam-confisco-de-respiradores.ghtml>.

4. Disponivel em: <https://saude.estadao.com.br/noticias/geral,confisco-de-luvas-a-respiradores-no-brasil-opoe-uniao-a-estados, $70003249899>$. 
Além do conflito entre União, estados e municípios, a configuração peculiar do sistema de saúde brasileiro, com uma camada pública (Sistema Único de Saúde - SUS) e outra privada (saúde suplementar), impóe ainda outras áreas de conflito. A Associação Nacional de Hospitais Privados (ANAHP) realizou reunióes no dia 3 de abril com o Supremo Tribunal Federal (STF) e o Ministério da Saúde (MS) e em seguida entregou um ofício ao presidente da Corte cobrando açôes para resolver a escassez de equipamentos e insumos necessários para o combate ao novo coronavírus nos hospitais. Apontando o "confisco" dos materiais realizado por alguns estados e municípios, a falta de estoque e o bloqueio na compra dos produtos da China feito pelos Estados Unidos, a ANAHP previu um colapso no setor, impossibilitando a prestaçáo de serviço, e pediu a intervençáo do STF para evitar abuso de autoridade dos estados e municípios. O presidente da ANAHP pediu que eventuais requisiçôes fossem feitas dentro de uma "visão sistêmica, [com] balizamento adequado e de forma fundamentada e menos gravosa possível”. Também a Confederação das Santas Casas de Misericórdia, Hospitais e Entidades Filantrópicas (CMB), uma das instituiçôes que assina o ofício, disse que os EPIs estáo chegando apenas nos hospitais públicos, o que estaria desequilibrando os serviços de saúde. A instituição representa 2.172 hospitais sem fins lucrativos em todo o país (sendo que 1.704 atendem o SUS) e responde por $50 \%$ de todo o atendimento da saúde pública. Os hospitais filantrópicos também são responsáveis por $60 \%$ dos tratamentos complexos do SUS (rádio e quimioterapia, por exemplo). Por fim, a Confederação Nacional de Saúde (CNS), outra entidade representante de hospitais privados entrou com uma ação direta de inconstitucionalidade (ADI) no Supremo, pedindo que todas as requisiçóes administrativas (chamadas pelos hospitais de "confisco") de materiais e serviços da rede particular passassem pelo crivo do MS: "todas as requisiçôes administrativas projetadas para serem exercidas por gestores de saúde estaduais ou municipais sejam submetidas ao prévio exame e autorização do Ministério da Saúde para serem, só depois disso, implementadas". Na visão da entidade, a lei de quarentena teria dado poder excessivo aos estados e municípios para requerer bens e serviços mediante o pagamento posterior de indenização justa, abrindo brecha para que gestores locais adotassem medidas sem controle prévio da Uniāo. ${ }^{5}$

Esse conflito deixou as primeiras páginas dos jornais, dando lugar a outro problema: as irregularidades nas compras de respiradores. Até o fechamento deste Texto para Discussão, já havia investigaçóes em onze estados e no Distrito Federal sobre irregularidades

5. Para mais informações, ver: <https://www.poder360.com.br/coronavirus/hospitais-privados-cobram-do-governo-materiais-de-protecao-contra-covid-19/>; e <https://noticias.uol.com.br/saude/ultimas-noticias/redacao/2020/04/04/hospitais-privados-acionam-stf-e-dizem-que-governo-esta-confiscando-epis.htm>. 
em compras relacionadas à pandemia, gerando 410 procedimentos preliminares ${ }^{6,7}$ e operaçóes ostensivas da Polícia Federal, tais como Placebo (RJ), Ragnarok (Consórcio Nordeste), Para Bellum (PA) e $\mathrm{O}_{2}$ (SC). Tais operações, com atuação também dos Ministérios Públicos e Tribunais de Contas, buscam apurar as negociaçóes feitas entre administração e fornecedores, cuja gravidade salta aos olhos frente a fatos como a não entrega, até o momento, de quase metade dos quase 7 mil respiradores comprados pelos estados, bem como pela discrepância entre os valores de aquisição, que variam entre R\$ 40 mil e R\$ 226 mil. $^{8}$

Esses problemas não são, no entanto, exclusividade do Brasil. Na Itália, por exemplo, Albano (2020) relata que o Departamento de Proteção Civil escolheu a Consip como agência executora para os procedimentos centralizados de aquisiçóes de 4 mil respiradores e EPIs - incluindo 13 milhóes de máscaras. Ocorreu, no entanto, de aparecerem outros compradores públicos que começaram a competir um com o outro, gerando-se um verdadeiro leilão, que contribuiu para uma alta dramática dos preços. Numa etapa seguinte, houve um planejamento de uma produção nacional de máscaras para a satisfação parcial das necessidades e, por fim, chegou-se a um preço máximo de $€ 0,50$ por máscara cirúrgica.

Nesse contexto de ruptura da cadeia de suprimentos e de concorrência predatória entre compradores, a Organização Mundial da Saúde (OMS) recomenda, além da racionalização da demanda e do uso dos insumos hospitalares, a gestão centralizada dessas aquisiçôes, contribuindo para o esforço de coordenação do abastecimento das unidades de saúde, evitando excessos e quebras de estoques (WHO, 2020). A transposição dessa reflexão para o cenário brasileiro requer uma apreciação dos desafios e das oportunidades de aperfeiçoar os mecanismos de agregação de demandas e as sistemáticas de compras

6. Para mais detalhes, ver: <https://politica.estadao.com.br/noticias/geral,compras-emergenciais-durante-pandemia-sao-investigadas-em-11-estados-e-no-df,70003298606>.

7. Cumpre reiterar que a possibilidade de compras de equipamentos de má qualidade ou inadequados para as necessidades prementes atuais - possibilidade esta verificada em várias das compras investigadas - seria mitigada ou até extinta se fosse observada a sugestão de Servo et al. (2020), que enfatizaram a necessidade de se obrigar a prestação de informações completas sobre os equipamentos, incluindo registro, ainda que simplificado, na Agência Nacional de Vigilância Sanitária (Anvisa). Os procedimentos que sugerimos na seção 5 pressupõem um mínimo de adequação dos bens adquiridos aos requisitos de funcionalidade e qualidade demandados pelos profissionais da linha de frente dos serviços de saúde. É importante saber a origem dos equipamentos oferecidos pela iniciativa privada, para se evitarem compras fora das especificações indicadas para os tratamentos a que se destinam.

8. Disponível em: <https://g1.globo.com/bemestar/coronavirus/noticia/2020/06/26/estados-compram-7-mil-respiradores-mas-menos-da-metade-e-entregue-valor-de-cada-equipamento-varia-de-r-40-mil-a-r-226-mil-no-pais.ghtml>. 
conjuntas disponíveis para os gestores públicos envolvidos no enfrentamento da emergência de saúde pública da Covid-19.

Em suma, os fatos relatados são as evidências recentes mais eloquentes da disfuncionalidade do sistema de compras governamentais brasileiro: entes compradores não se coordenam, e essa falta de articulação os deixa em posição desvantajosa frente aos vendedores; essa desvantagem se acentua em momentos de restrição de oferta como a atual; as sistemáticas existentes de compras coordenadas e de meios de pagamento não são nem flexíveis nem ágeis o suficiente para lidar com flutuaçôes de mercado, em particular, durante crises de abastecimento; e o controle de qualidade das compras é incapaz de prevenir compras de equipamentos fora das especificaçôes. ${ }^{?}$

Este texto tem o objetivo de reunir elementos para propor um novo modelo concertado, ágil e flexível de compras públicas voltado para situaçóes como a presente, com maior colaboração entre os entes públicos e o possível envolvimento de entes privados que atendam majoritariamente pacientes do SUS, ao mesmo tempo em que se preservam a transparência e a accountability, e se facilita a fiscalização. Para viabilizar tal modelo, algumas alterações legais e procedimentais são necessárias, algumas inclusive no nível mais geral das compras e contrataçóes, o que não desnatura a proposta de sua implementação em caráter experimental, uma vez que se limita às questóes relacionadas à Covid-19. Todavia, há que se considerar que, alcançando resultados satisfatórios, a proposta pode se tornar definitiva e, inclusive ser expandida para outros contextos (objetos de contratação, modalidades, poderes e entes).

O desafio de se alcançar um nível de colaboração entre os entes é grande, como ocorreu em países menores - Austrália, Nova Zelândia e Irlanda - ou em países maiores, como Itália, Coreia e Alemanha. Em todos esses países e na União Europeia como um todo, uma liderança institucional forte, dando orientaçóes coerentes, possibilitou uma ação coordenada das instituiçôes para resolver problemas sérios como cadeias de valor esgarçadas, disputa entre compradores e altas de preços (OCDE, 2020a). As ideias trazidas neste estudo, por sua vez, refletem o estado da arte do Brasil e buscam desenvolver as soluções mais viáveis com os instrumentos legais e institucionais de que dispomos.

9. Não se trata, portanto, de simplesmente obter preços baixos, mas sim de comprar melhor, com mais eficiência, e obtendo confiabilidade no abastecimento (seção 3). 
Este estudo tem mais seis seções além desta introdução. Na próxima, fazemos uma motivação para um arcabouço de compras centralizadas em saúde. Em seguida, varremos algumas experiências internacionais de compras centralizadas e o que tem sido feito no Brasil a respeito. As seçôes seguintes detalham, então, o arcabouço legal para se implementar um sistema de registro de preços de emergência, que chamamos de acordo-marco, e um leque de propostas de implementação para esse sistema. A última seção consolida as considerações finais.

\section{MOTIVAÇÃO}

Compras conjuntas de órgãos públicos no Brasil seguem o modelo do Sistema de Registro de Preços (SRP). Ele tem um vício de origem: os diversos custos administrativos envolvidos na organização do certame licitatório não são devidamente precificados (não há nenhum tipo de remuneração ou compensação dos esforços ao órgão gestor da Ata de Registro de Preços), gerando uma provisão subótima de bons registros de preços. De fato, os estímulos para o órgão gestor em montar uma boa compra advêm tâo somente do poder coercitivo de seus superiores e dos órgáos de controle, e aquele não se percebe como um ator fundamental e determinante para o sucesso das compras, nem como representante dos demais participantes ou beneficiados pelo instrumento frente ao mercado. Apesar disso, o que salta mais aos olhos de quem se debruça sobre os dados de compras públicas parece ser justamente o contrário: uma enorme gama de compras na mesma esfera administrativa. Fiuza e Medeiros (2014) mostraram que, nas compras federais de medicamentos com registro de preços, o número médio de unidades participantes era de 2,7, o que evidenciava uma baixíssima concentração de compras no serviço público federal.

E como está a situação atual? Para respondermos, fizemos uma extração de dados de compras de produtos do Complexo Industrial da Saúde no Data Warehouse Comprasnet, da seguinte maneira: primeiro, reproduzimos a lista de categorias de materiais utilizada na Nota Técnica do Ipea no 63/2020 (Servo et al., 2020), que permeia vinte 
padróes descritivos de mercadorias (PDMs) e 244 códigos de materiais (Catmat). ${ }^{10}$ A eles acrescentamos a classe de materiais 16505, que compreende 1.205 PDMs e 4.674 Catmats.

Selecionamos, então, com base nesse filtro, todos os itens de compra com classificação em um dos 4.918 Catmats. Tabulamos o número de itens de compras, o número de unidades participantes em cada item de compra, o número de fornecedores para cada item de compras, o valor empenhado e o valor total homologado por ano e a unidade responsável pela compra, de 2014 a 2020 (até março). ${ }^{11}$

Também tabulamos o valor empenhado por unidade compradora, as quantidades solicitadas e as efetivamente compradas. Diferentemente da amostra utilizada em Servo et al. (2020), não foi possível uniformizar a unidade de medida de cada Catmat (lá referida como Código BR), portanto a agregação das quantidades solicitadas e compras, mesmo em um mesmo Catmat, pode ser uma informação distorcida do tamanho das compras, razão pela qual não reportamos essas duas variáveis, ainda que tenham sido coletadas.

10. As compras e contratações da administração pública seguem descrições de itens que estão dispostos no Catálogo de Materiais (Catmat) e no de Serviços (Catser) do Sistema Integrado de Administração de Serviços Gerais (Siad). Tais catálogos estão organizados conforme uma hierarquia, indo do menor ao maior nível de agregação, que são: i) item: objeto especificado de forma completa, com todas as características necessárias para sua identificação e que o tornam único. Assim, será utilizado nos processos de compra e contratação (exemplo: curativo, tipo: hidrogel, revestimento: ácidos graxos essenciais); ii) padrão descritivo de material (PDM): conjunto de características consideradas básicas, agrega vários itens que possuem a mesma finalidade ou função (exemplo: curativo); iii) classe: nível de organização orientado para a finalidade específica que agrega os PDMs que atendem a uma função comum (exemplo: materiais cirúrgicos para curativos); iv) grupo: maior nível de agregação, representando, de forma genérica, um conjunto de materiais ou serviços que possuem alguma afinidade entre si (exemplo: equipamentos e artigos para uso médico, dentário e veterinário). Em particular, na classe de drogas e medicamentos, tipicamente o PDM delimita um princípio ativo e dentro dele cada Catmat define uma mesma concentração e forma farmacêutica, e eventualmente alguma associação (quando a associação não define um PDM em separado) - exemplo: o policresuleno é um PDM (18773), e dentro dele existem Catmats com o princípio ativo puro (313591 e 313592) ou em associação com a chinchocaína (313595, 367725 e 396356); outras associações sem um princípio ativo principal formam PDMs específicos, como multivitaminas (15398) e vacinas (15458).

11. 0 valor total homologado mede o valor adjudicado ao fornecedor selecionado, e é o produto do preço vencedor (valor unitário homologado) pela quantidade solicitada pelas unidades compradoras (que podem ser muitas, em caso de registro de preços). No caso do SRP, esse valor pode ser executado por completo ou em parte por cada uma das unidades. No outro sistema, o de preços praticados, ou o valor todo é executado ou a compra é cancelada. Antes da compra, o valor precisa ser empenhado, por isso o valor empenhado é uma métrica mais confiável da real atividade de compra. 0 empenho pode acontecer em até um ano (caso extremo do SRP), havendo um prazo para pagamento do empenho de trinta dias após o recebimento do bem. Para facilitar a comparação, agregamos as compras sempre pelo ano da data de referência da compra, que concerne os procedimentos licitatórios. 
TABELA 1

Composição da amostra

\begin{tabular}{|c|c|c|c|}
\hline Nome da classe de materiais & Código da classe & Número de PDMs & $\begin{array}{l}\text { Número de } \\
\text { Catmats }\end{array}$ \\
\hline Equipamento para segurança e salvamento & 14240 & 2 & 16 \\
\hline Drogas e medicamentos & 16505 & 1.205 & 4.674 \\
\hline Instrumentos, equipamentos e suprimentos médicos e cirúrgicos & 16515 & 6 & 75 \\
\hline Vestuário hospitalar e cirúrgico e itens correlatos de finalidades especiais & 16532 & 6 & 62 \\
\hline Produtos químicos & 16810 & 1 & 3 \\
\hline Sacos e bolsas & 18105 & 2 & 20 \\
\hline Sabonetes, artigos para barbear e dentifrícios & 18520 & 1 & 5 \\
\hline Artigos de papel para higiene & 18540 & 2 & 63 \\
\hline Total & 8 & 1.225 & 4.918 \\
\hline
\end{tabular}

Fonte: DW Comprasnet.

Elaboração dos autores.

As vendas dos fornecedores agregadas por Catmat e ano também foram tabuladas, e calculadas as participaçóes de mercado de cada um nas diversas classes, notando que, em algumas classes, as categorias amostradas são bem poucas, chegando a duas apenas. Como os fornecedores tipicamente náo atendem a todas as categorias de uma mesma classe, mas se especializam em alguns nichos, isso significa que é muito mais fácil encontrar uma maior concentraçáo nas classes com menos categorias, e menor concentraçáo na classe 16505 , com o maior número de Catmats da amostra (tabela 1).

Diante do exposto, as principais conclusóes a que chegamos ao analisarmos esses números, até o momento, e que serão exploradas nos próximos tópicos são:

- grande concentração do fornecimento em poucas empresas;

- as compras nas classes de materiais estudados são concentradas em poucos ministérios e órgãos, mas dentro deles há uma grande pulverização entre as unidades compradoras; e

- há correlaçôes negativas entre valores das compras e número de propostas recebidas.

\subsection{Grande concentração do fornecimento em poucas empresas}

Ao selecionarmos os vinte maiores fornecedores por valor homologado em cada classe, notamos que esse número é suficiente para atender de $90 \%$ a $100 \%$ do valor homologado em seis das sete classes, baixando para $58 \%$ a $88 \%$ na classe 16505 (gráfico 1). Note-se que a classe de medicamentos, que já era a menos concentrada no início da série, foi também a que mais se desconcentrou ao longo do período, ainda que com uma significativa reversão em 2019. Outra queda notável da concentração, ainda que 
também parcialmente revertida em 2019, foi a do segmento de vestuário hospitalar (que engloba aventais, luvas, máscaras e gorros). A queda no segmento de artigos de papel (toalhas e lenços descartáveis) também foi significativa, mas foi totalmente revertida no fim do período.

\section{GRÁFICO 1}

Participação dos vinte maiores fornecedores no valor homologado total de cada classe ou segmento (2014-2019)

$$
(\mathrm{Em} \%)
$$

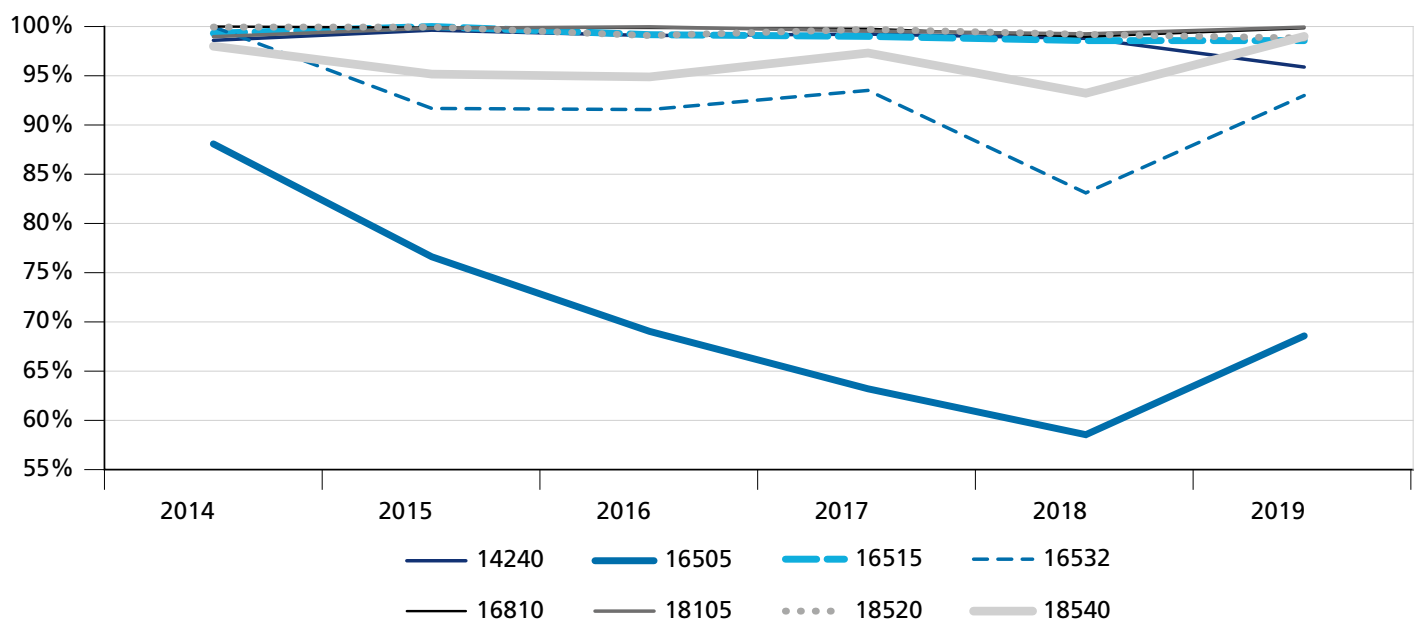

Fonte: DW Comprasnet. Elaboração dos autores.

Tomando como métrica o valor empenhado, o padrão foi diferente. Enquanto as classes de vestuário hospitalar e artigos de papel se desconcentraram ao longo do período, revertendo a primeira parcialmente e a segunda totalmente em 2019, a concentração na classe de medicamentos subiu. Ainda que os patamares sejam mais altos que os de valor homologado (entre $68 \%$ e $89 \%$ ), há mais classes no piso do intervalo. As concentraçóes comparativamente mais baixas em cada uma das três classes apontadas indicam que empresas fornecedoras que arremataram os maiores nacos das compras públicas federais nesses segmentos não viram converter-se as suas expectativas de vendas (valor homologado) em vendas efetivas (valor empenhado) (gráfico 2). 


\section{GRÁFICO 2}

Participação dos vinte maiores fornecedores no valor empenhado total de cada classe ou segmento (2014-2019)

$$
\text { (Em \%) }
$$

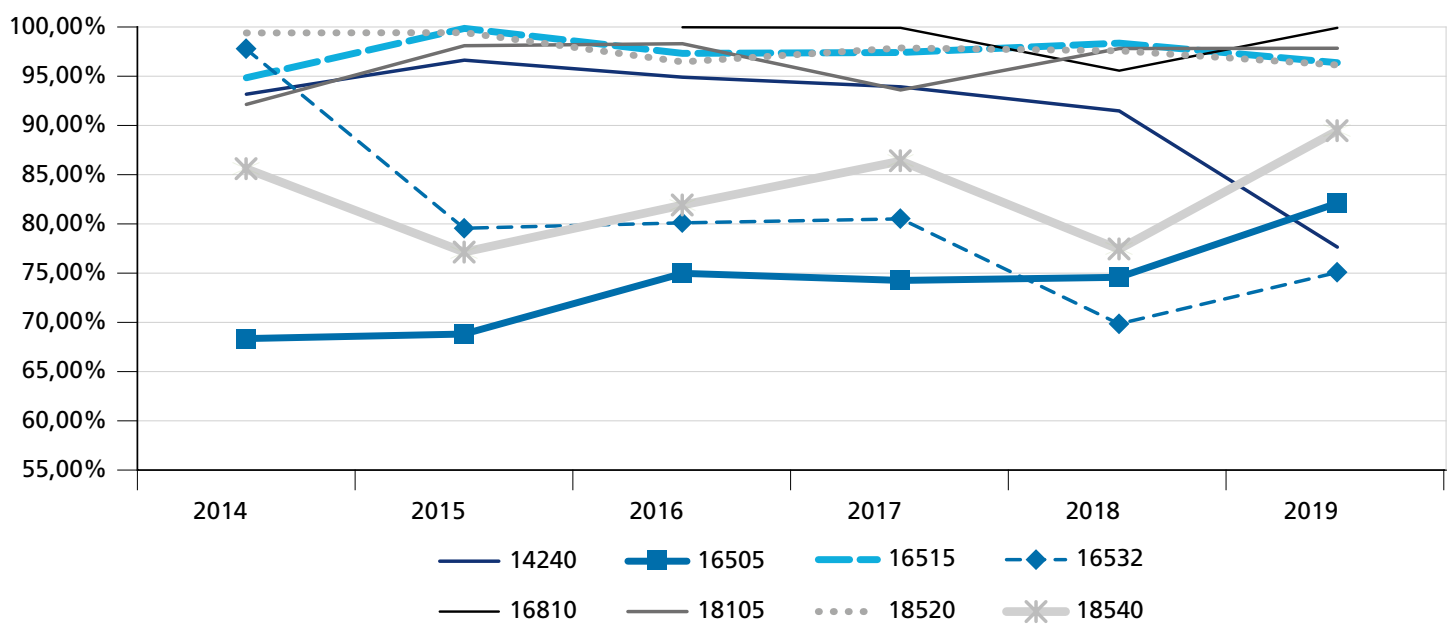

Fonte: DW Comprasnet.

Elaboração dos autores.

ACHADO 1: os vinte maiores fornecedores por valor homologado em cada classe selecionada (restrita aos Catmats listados) respondem por $90 \%$ a $100 \%$ do valor homologado em seis das sete classes, baixando para $58 \%$ a $88 \%$ na classe 16505 . Tomando como métrica o valor empenhado, o padrão foi diferente. Enquanto as classes de vestuário hospitalar e artigos de papel se desconcentraram ao longo do período, revertendo a primeira parcialmente e a segunda totalmente em 2019, a concentraçãa na classe de medicamentos subiu. Ainda que os patamares sejam mais altos que os de valor homologado (entre $68 \%$ e $89 \%$ ), há mais classes no piso do intervalo.

\subsection{Concentração das compras nas classes de materiais de interesse}

As classes de materiais estudadas têm comportamentos bem diferentes entre si, nas categorias incluídas, mas, na maioria dos casos, esse comportamento não tem tido muitas alteraçóes ao longo dos anos, razão pela qual descrevemos alguns indicadores separando-os apenas por classe.

Comecemos pela participação dos órgãos nos principais indicadores de atividade de compras: quantidade de itens de compra e valor empenhado. No caso do valor empenhado, essa participação pode ser medida pela ótica da unidade compradora que pertence ao órgáo, ou pela ótica da unidade responsável pela compra que pertence ao órgão. No caso do valor homologado, a agregação mais segura é pelo órgão responsável pela compra. 
No primeiro indicador (figura A.1, apêndice A), notamos uma dominância clara dos ministérios da Defesa e da Educação como órgãos compradores nas classes de equipamentos de segurança e vestuário, seguidos um pouco mais de longe, pelo MS - que só alcança participaçóes um pouco mais expressivas nas categorias de drogas e medicamentos; instrumentos cirúrgicos; equipamentos para segurança e salvamento; e vestuário hospitalar. Isso pode refletir uma maior multiplicidade de unidades administrativas nestes ministérios, ${ }^{12}$ até porque o MS organiza muitos registros de preços que reúnem unidades administrativas de outras esferas, como governos e secretarias estaduais e municipais (que são eliminadas de nossa amostra, por não podermos rastrear os empenhos delas no Sistema Administrativo de Serviços Gerais, o Siasg). Aparecem outros órgãos além do MS nas outras posições do ranking, como os ministérios da Previdência Social, Economia e Justiça, a Empresa Brasileira de Pesquisa Agropecuária (Embrapa) e a Justiça Eleitoral.

No indicador de valor empenhado por órgão comprador (figura A.2), há uma pequena alteração no ordenamento das distribuiçôes entre os órgãos. A classe de drogas e medicamentos tem o predomínio quase absoluto do MS, que, no pacto tripartite do SUS, é responsável exclusivo pela aquisição e distribuição de alguns produtos de maior custo, como os antirretrovirais, vacinas, soros, imunoglobulinas, hemoderivados (Componente Estratégico da Assistência Farmacêutica). Este ministério tem também maior proeminência nas categorias de instrumentos cirúrgicos e produtos químicos (em que alterna o primeiro lugar com a Educação, deixando a Defesa em terceiro), e de vestuário hospitalar (dominado pela Educação, Saúde e Defesa nesta ordem). Nas demais categorias, o domínio numérico de Educação e Defesa é mais pronunciado. Esse padrão praticamente se repete quando agregamos o valor empenhado ou o valor total homologado segundo o órgão superior da unidade responsável pela compra (figuras A.3 e A.4).

É interessante notar que essa grande concentração das compras e dos empenhos de produtos de saúde em três grandes ministérios não significa que as compras sejam necessariamente grandes. Como comentamos antes, há algumas dezenas, na verdade, milhares de unidades compradoras com registros no período: 2.456 no total, espalhadas em 93 órgãos. Em números de unidades participantes, também existe uma grande concentração: 95\% delas fica em apenas vinte órgãos, sendo quatorze ministérios, três

12. No caso da Defesa, cada destacamento com unidade de logística própria conta como uma unidade compradora separada. No Ministério da Educação, instituições federais de ensino médio e superior e hospitais universitários federais executam, cada uma, suas próprias compras, ainda que como meros participantes de atas de registro de preços organizadas por uma central, como, neste caso, a Ebserh (subseção 5.2). 
ramos da Justiça, Embrapa, Presidência da República e Ministério Público da União (MPU). Os quatro primeiros (Educação, Defesa, Saúde e Economia) respondem por $70 \%$ das unidades compradoras).

Pois bem, com tamanha pulverização de compras, o número de itens de compras conjuntas tem distribuiçóes acumuladas com grande concentração no valor um, ${ }^{13}$ como podemos ver na figura A.5. Ela mostra que, com exceção das categorias de drogas e medicamentos e vestuário hospitalar, um número significativo de compras de um mesmo código de material, tem sido, cada uma, para apenas uma unidade compradora no ano. Nas exceções, aparentemente há um grande número de itens de compra no mesmo ano e código de material comprados em conjunto. Isso mostra como a maioria das categorias estudadas sofre de pouca agregação de compras. Quanto ao valor empenhado, seja agregando pela unidade compradora, seja pela unidade responsável pela compra, as distribuiçóes acumuladas apontam, no geral, para uma grande concentraçáo dos valores nas grandes compras, com as pequenas respondendo por fatias mínimas do bolo, naquelas distribuiçôes mais parecidas com um L espelhado. Esses grandes valores também variam bastante em ordem de grandeza entre as classes. Distribuiçóes com trechos mais inclinados indicam uma maior variedade de valores empenhados, reduzindo a concentração do montante total (ver a agregação por unidade responsável pela compra na figura A.6).

Outras interessantes distribuiçóes acumuladas são obtidas na agregação dos valores totais homologados por código de material (Catmat) e unidade responsável pela compra. Nota-se uma dispersão maior dos valores nas várias classes de materiais em comparação com as distribuiçóes de valores empenhados por unidade compradora.

ACHADO 2: ao tabularmos as distribuições do valor das compras e da quantidade de itens de compra por órgão (seja o órgão superior da unidade compradora, seja o da unidade responsável pela compra), notamos um predomínio do MS nos valores homologado e empenhado, enquanto os ministérios da Defesa e Educação predominam nas quantidades de itens, seguidos mais de longe pela Saúde. Isso reflete a divisão de compras de medicamentos entre União, estados e municípios, bem como a pulverização de unidades compradoras nos respectivos órgãos.

A semelhança entre as distribuições nos indica que as compras centralizadas e organizadas por uma unidade responsável cobrem majoritariamente (em valor) outras unidades participantes do mesmo órgão, ou seja, parece haver especialização e/ou pouca coordenação entre eles.

Assim, qualquer coordenação bem-sucedida das compras de insumos de saúde no âmbito federal requer 0 alinhamento das estratégias de compras entre esses três ministérios e idealmente deveria por esse alinhamento começar.

Um exemplo que pode nos inspirar é o da Colômbia, onde foi implantada a central

13. Como a escala do eixo $X$ é logarítmica, valores zero na abscissa correspondem à quantidade um, que é o antilogaritmo do zero. 
de compras Colombia Compra Eficiente (CCE). Diferente da central de compras brasileira, ela verdadeiramente centralizou todas as compras no nível nacional e boa parte das compras subnacionais, pois a adesão aos seus acordos-marco tornou-se obrigatória (box 1). Maior centralização também tem sido uma estratégia em alguns países que efetuaram fusōes de centrais de compras, como a Suécia (que, em 1995, reuniu as centrais de compras nacional e dos municípios numa só empresa, a SKI): ${ }^{14}$ Portugal que em 2012 criou a Entidade de Serviços Partilhados da Administração Pùblica (eSPap) a partir da consolidação das missóes e atribuiçôes de compras dos anteriores Instituto de Informática (II) do Ministério das Finanças, da Empresa de Gestão Partilhada de Recursos da Administração Pública, E.P.E. (GeRAP) e da Agência Nacional de Compras Públicas, E.P.E. (ANCP) ${ }^{15}$ a Índia recentemente anunciou a fusão de seu marketplace GeM com o Portal Central de Compras Públicas $(\mathrm{CPPP})^{16}$ ainda para o presente ano; ou o Reino Unido, que possui uma história com sequência de fusóes e incorporações: ${ }^{17}$

- em 1991, foi criada a Buying Agency;

- em 2000, a Buying Agency foi incorporada ao Office of Government Commerce (OGC) como uma agência executiva;

- em 2001, o OGC foi fusionado com a Divisão de Serviços Administrados da Agência Central de Computação e Telecomunicaçóes para formar a OGC Buying Solutions, uma agência do Tesouro Britânico.

- em 2009, a agência foi renomeada como Buying Solutions e absorveu a responsabilidade pelas compras náo clínicas do Serviço Nacional de Saúde (NHS).

- em 2011, a Buying Solutions foi renomeada Government Procurement Service (GPS); e

- em 2014, o Crown Commercial Service (CCS) reuniu o GPS, as funçóes comerciais do Gabinete, e as compras de bens e serviços comuns dos departamentos (equivalentes aos nossos ministérios).

14. Ver OCDE (2000, p.12).

15. Disponível em: <https://www.espap.gov.pt/noticias/Paginas/noticia.aspx?nid=1225>.

16. Disponível em: <https://economictimes.indiatimes.com/news/economy/policy/government-to-merge-central-public-procurement-portal-with-gem/articleshow/74504572.cms>.

17. Disponível em: <https://bit.ly/2E390Co>. 


\section{BOX 1 \\ Estudo de caso: Colombia Compra Eficiente}

"Todos os três estudos internacionais sobre compras na Colômbia - o Relatório de Avaliação de Compras do País (CPAR) de 2000 do Banco Mundial , o CPAR de 2005 do Banco Mundial e Banco Interamericano de Desenvolvimento e o Status da Reforma de Compras Públicas na Colômbia, do Banco Mundial e Banco Interamericano de Desenvolvimento em 2009 - recomendaram a consolidação, a unificação e a harmonização das regras de compras, a criação de uma agência central de compras públicas e a criação de uma plataforma de compras eletrônica (grifo nosso). Os três principais pontos fracos da Colômbia foram encontrados nos três estudos, não na estrutura legal da Colômbia, mas na organização e operação de compras e na integridade e transparência do sistema.

Em resposta a essas recomendações, e com base em seus planos nacionais, o governo da Colômbia estabeleceu a agência central de compras Colombia Compra Eficiente em 2012, por meio da implementação do Decreto-lei no-4.170/2011. A Colombia Compra Eficiente é responsável por estabelecer acordos-quadro, atualizar e supervisionar a plataforma de compras eletrônicas, coordenar e assessorar a política de compras e auxiliar as entidades compradoras e fornecedores nas práticas de compras."

As principais tarefas e desafios atribuídos à central Colombia Compra Eficiente estão no quadro 1.

QUADRO 1

Matriz de desafios e ações propostas pela Colombia Compra Eficiente

\begin{tabular}{|c|c|c|}
\hline Desafio principal & Ações de curto prazo & Ações de longo prazo \\
\hline $\begin{array}{l}\text { Estabelecer o papel da CCE como um centro } \\
\text { para capacitação e expertise em compras. }\end{array}$ & $\begin{array}{l}\text { Lançar uma campanha de divulgação dos } \\
\text { serviços da CCE. }\end{array}$ & $\begin{array}{l}\text { Organizar treinamento pela CCE para outros } \\
\text { agentes de compras. }\end{array}$ \\
\hline $\begin{array}{l}\text { Abordar as disparidades de compras entre } \\
\text { os níveis central e subcentral e entre os } \\
\text { níveis subcentrais. }\end{array}$ & $\begin{array}{l}\text { Prover um help-desk e ferramentas práticas } \\
\text { em como usar acordos-quadro. }\end{array}$ & $\begin{array}{l}\text { Harmonizar práticas e procedimentos de } \\
\text { compras. }\end{array}$ \\
\hline $\begin{array}{l}\text { Profissionalizar a força de trabalho de } \\
\text { compras. }\end{array}$ & $\begin{array}{l}\text { Criar postos de trabalho específicos em } \\
\text { compras, com habilidades claras e planos } \\
\text { de carreira para a CCE. }\end{array}$ & $\begin{array}{l}\text { Desenvolver uma estratégia comercial } \\
\text { para a CCE, com atendimento dedicado } \\
\text { para clientes. }\end{array}$ \\
\hline $\begin{array}{l}\text { Aprimorar a plataforma de compras } \\
\text { eletrônicas. }\end{array}$ & $\begin{array}{l}\text { Lançar a implementação dos recursos de } \\
\text { leilão eletrônico da nova plataforma de } \\
\text { compras eletrônicas. }\end{array}$ & $\begin{array}{l}\text { Treinar funcionários públicos e fornecedores } \\
\text { nos recursos e no potencial da plataforma } \\
\text { de compras eletrônicas. }\end{array}$ \\
\hline $\begin{array}{l}\text { Aprimorar os recursos de business intelligence } \\
\text { da plataforma eletrônica. }\end{array}$ & $\begin{array}{l}\text { Coletar dados de participação e adjudicações } \\
\text { em compras e realizar análises estatísticas } \\
\text { com eles. }\end{array}$ & $\begin{array}{l}\text { Desenvolver políticas nacionais para } \\
\text { aperfeiçoar os procedimentos de compras } \\
\text { ou perseguir objetivos secundários (verdes/ } \\
\text { outros) com base em evidências coletadas. }\end{array}$ \\
\hline $\begin{array}{l}\text { Padronizar a variedade, a qualidade e o } \\
\text { preço dos produtos e serviços comumente } \\
\text { adquiridos. }\end{array}$ & $\begin{array}{l}\text { Desenvolver especificações para acordos- } \\
\text { quadro com base em análise de necessidades } \\
\text { e pesquisa de mercado adequadas. }\end{array}$ & $\begin{array}{l}\text { Garantir um diálogo regular com } \\
\text { potenciais fornecedores para acompanhar } \\
\text { o desenvolvimento dos mercados em um } \\
\text { banco de dados. }\end{array}$ \\
\hline
\end{tabular}

Fonte: OCDE (2013, anexo B) 


\subsection{Correlações negativas entre valores das compras e número de propostas recebidas}

Por fim, vale a pena apresentar alguns gráficos de dispersáo (scatter plots). Na figura 3, vemos a relação estatística entre, de um lado, o valor total homologado ${ }^{18}$ por Catmat $\mathrm{e}$ ano, e o número total de propostas recebidas (quantidade de itens-fornecedor, que conta o número de empresas que submeteram propostas e, eventualmente, lances, ${ }^{19} \mathrm{em}$ cada item de compra e ano, podendo ser contados várias vezes se oferecerem propostas em vários itens, ainda que numa mesma compra). $\mathrm{O}$ que mais chama a atenção é a aparente correlação negativa entre as duas variáveis. Esse comportamento merece uma análise mais aprofundada, levando-se em conta outras variáveis explicativas, mas a primeira impressão é que as compras com escala muito grande não atraem empresas pequenas, que não têm capacidade de atendimento para oferecer a quantidade solicitada, ou sequer possam atender critérios de qualificação financeira. Outra explicação plausível é o efeito da Lei Complementar $n^{\circ}$ 147, que modificou o Estatuto da Micro e Pequena Empresa (Lei Complementar no 123 ), obrigando as unidades compradoras a destacar lotes (itens) de compras separados para micro e pequenas empresas (MPEs). ${ }^{20}$ Esse resultado se mantém quando dividimos o valor total homologado e as quantidades de itens-fornecedor pela quantidade de itens de compra para obtermos os valores médios por item de compra daquele Catmat/ano (figura 4).

18. 0 ideal seria usarmos o valor estimado da compra, que pode ser obtido na época da licitação pelos participantes, mas esta métrica não é documentada em casos de compra direta. Ademais, não é irrazoável admitir que os licitantes tenham alguma expectativa do valor total a ser homologado, mesmo antes do certame, dada a quantidade estimada (solicitada).

19. Na nossa amostra não houve nenhum filtro por modalidade. Note que em contratações diretas (dispensa, inexigibilidade, convite, tomada de preço e concorrência), só é registrada no sistema a proposta vencedora. Nos pregões, mesmo que a empresa licitante não submeta lance na fase aberta, ela é contada nesta métrica de quantidade de itens-fornecedor, em cada item de compra onde ela submeter uma proposta, ainda que seja desclassificada.

20. Art. 48. Para o cumprimento do disposto no art. 47 desta Lei Complementar, a administração pública:

I - deverá realizar processo licitatório destinado exclusivamente à participação de microempresas e empresas de pequeno porte nos itens de contratação cujo valor seja de até $\mathrm{R} \$ 80.000,00$ (oitenta mil reais);

(...)

III - deverá estabelecer, em certames para aquisição de bens de natureza divisível, cota de até $25 \%$ (vinte e cinco por cento) do objeto para a contratação de microempresas e empresas de pequeno porte. 
FIGURA 3

Valor total homologado versus quantidade de itens-fornecedor (2014-2019)

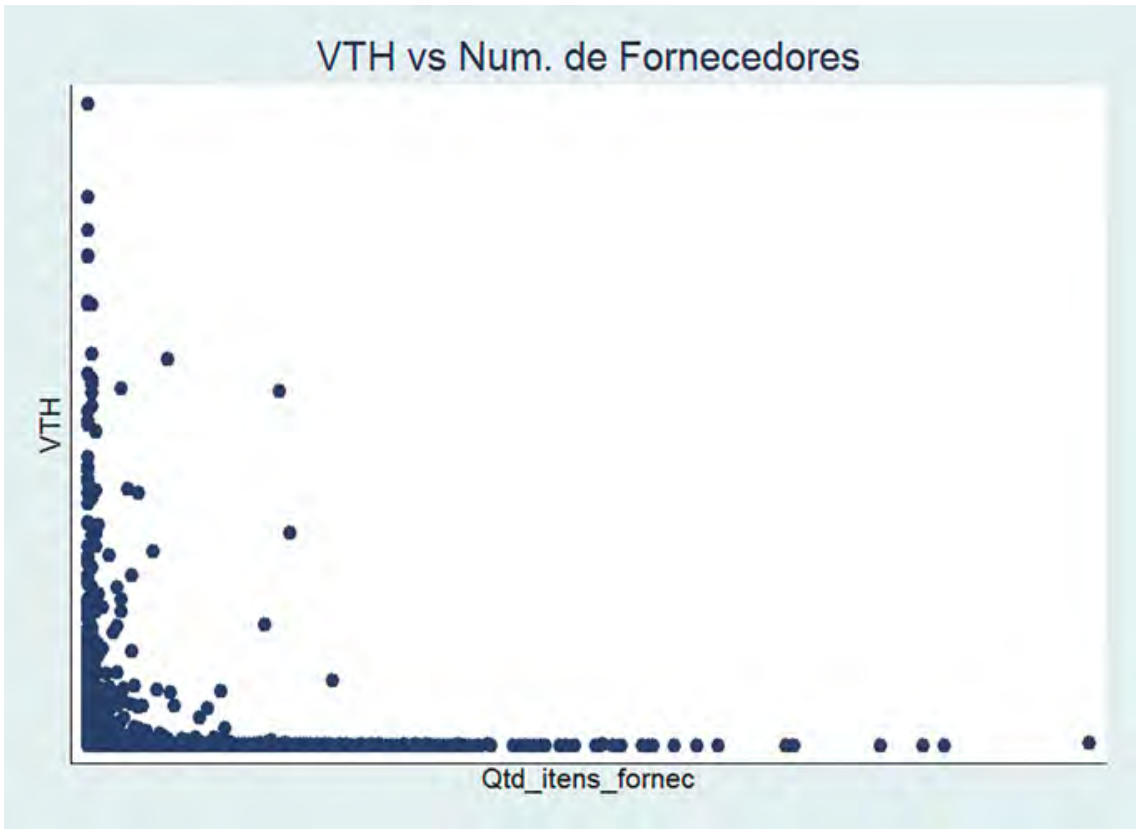

Fonte: DW Comprasnet.

Elaboração dos autores.

FIGURA 4

Valor total homologado médio por item de compra versus número médio de fornecedores por item de compra (2014-2019)

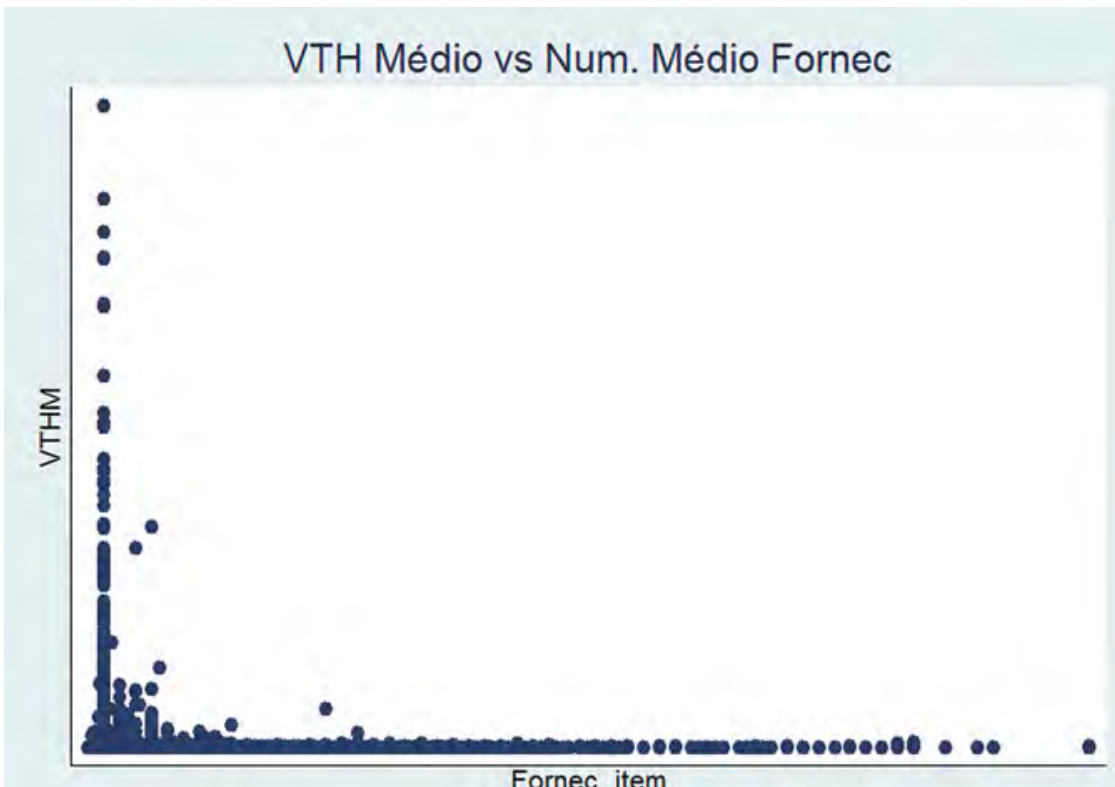

Fornec_item 
A correlaçáo parcial entre o número de compradores (tanto o absoluto do ano como a média por item de compra) e o número de fornecedores (quantidade de itens-fornecedor no Catmat/ano e a razão entre esta e a quantidade de itens de compra) aparenta ser semelhante à anterior. Além da quantidade de compradores no item ter alguma correlação com o valor total homologado, há que se lembrar que, quanto maior o número de compradores, maior a dispersão de custos de transporte e maiores os riscos de inadimplência e intercorrências contratuais com algum dos compradores, o que pode também contribuir para espantar potenciais fornecedores (figuras 5 e 6 ).

O que se poderia deduzir dessa impressão inicial? Que o uso do Sistema de Registro de Preços como acontece atualmente eleva a escala de operação mínima para um licitante atender às encomendas de grupos grandes de compradores, que normalmente se juntam nas atas de registro de preços. Os licitantes menores são, nessas compras, alijados da disputa, pois não têm condiçóes de atender à quantidade estimada total se as encomendas acontecerem de uma só vez. Isso porque o modelo de registro de preços é eminentemente unifornecedor: só são adjudicados mais de um fornecedor na ata se o primeiro colocado ofertar uma quantidade menor que o total estimado, e mesmo assim o segundo colocado só será convocado a vender se o primeiro atingir sua quota.

FIGURA 5

Quantidade de itens de compra das unidades participantes total do Catmat/ano versus quantidade de itens-fornecedor total do Catmat/ano (2014-2019)

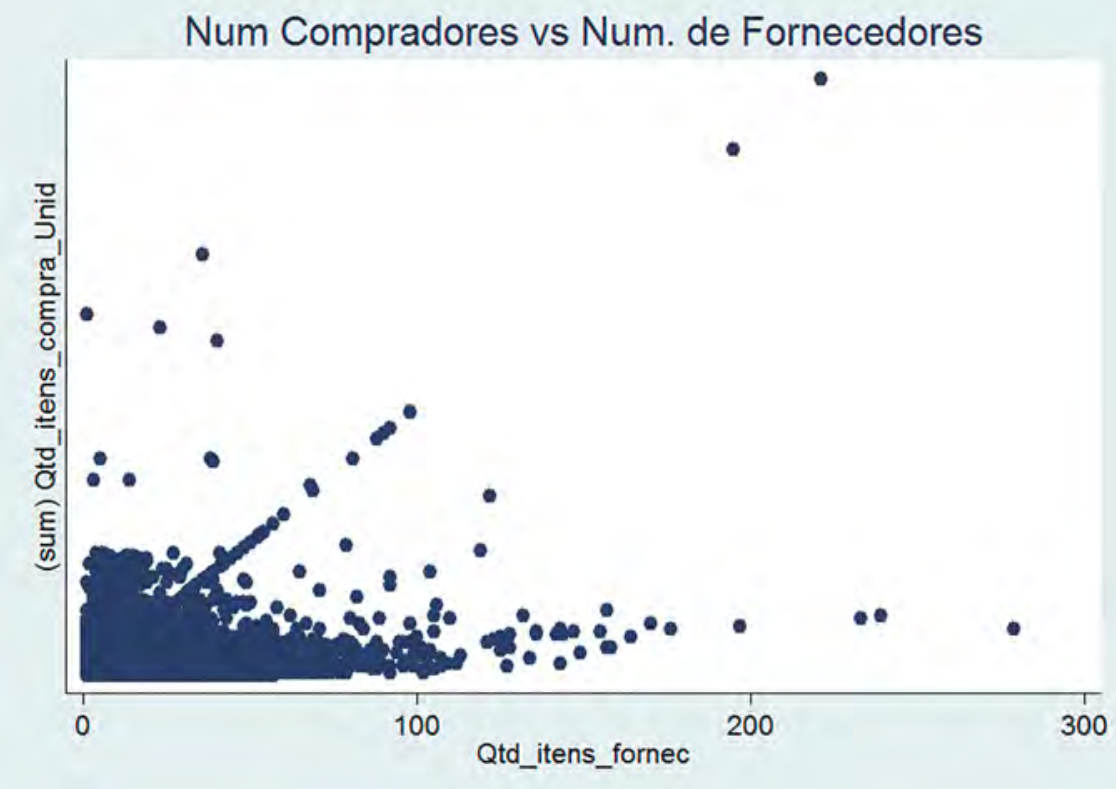


FIGURA 6

Número médio de unidades compradoras por item de compra versus número médio de fornecedores por item de compra (2014-2019)

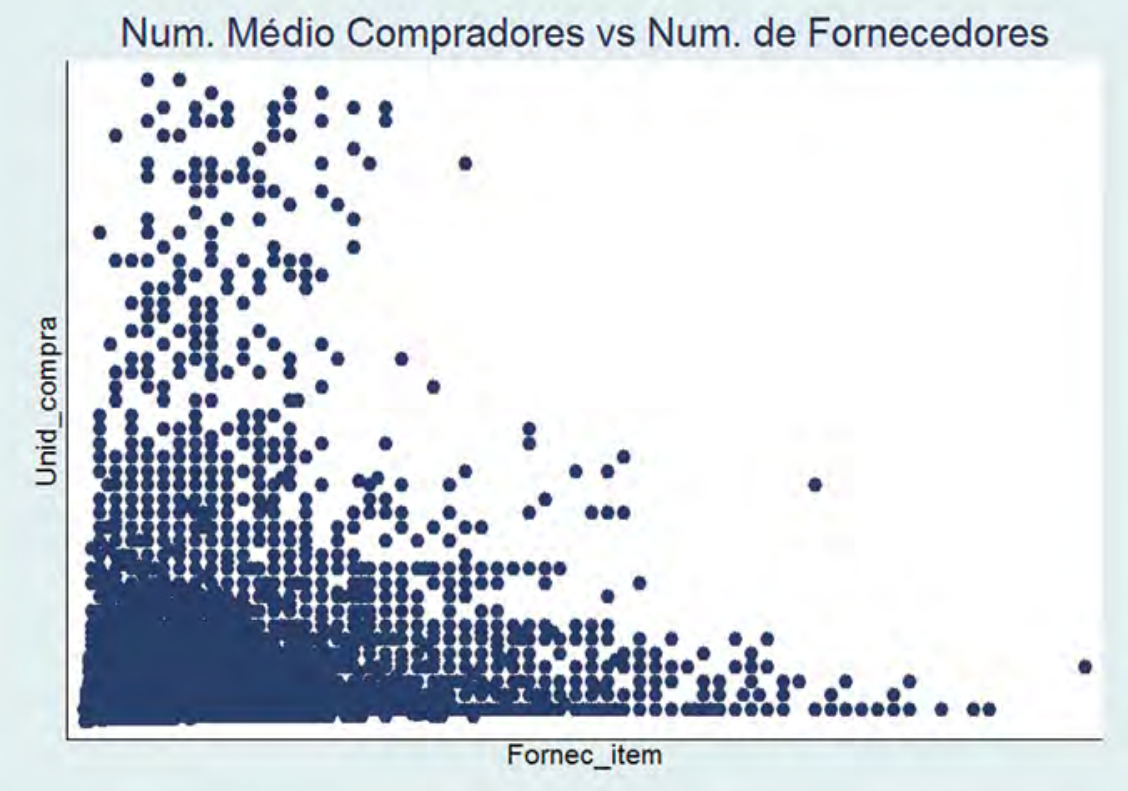

Fonte: DW Comprasnet.

Elaboração dos autores.

Assim, a legislação em favor das microempresas (ME) e empresas de pequeno porte (EPP) veio apenas como um remendo para esse problema de exclusão, não o solucionando por completo. Como mencionamos anteriormente, a Lei Complementar no 147 modificou o Estatuto Nacional da Microempresa e da Empresa de Pequeno Porte para obrigar os compradores públicos a separar itens de compra (isto é, lotes) para ME/EPP. Essa solução é parcial: primeiro, porque beneficia apenas as micro e pequenas, deixando as médias de fora; segundo, porque, no máximo, dobra o número de fornecedores potenciais de um Catmat para quatro. ${ }^{21}$

Esse problema de escala excessiva para os pequenos fornecedores foi apontado na Itália, que criou em 2004 o MePA (mercado eletrônico de compras públicas), um marketplace que facilita e barateia o acesso das PMEs ao mercado público (OCDE, 2018, p. 67-68). Também na Irlanda o relatório anual de 2014 do Escritório de Compras

21. Tipicamente, quando o fornecedor mais bem colocado na licitação não oferta o total da quantidade solicitada, o segundo colocado é convocado e incluído na ata de registro de preço. São raríssimos os casos em que mais de dois fornecedores são incluídos numa ata, daí podermos asseverar que a divisão de um item em dois pode alcançar, no máximo, quatro fornecedores. 
Governamentais, a central de compras do país, apontou que, dos 122 acordos-quadro em vigor, 67\% dos adjudicados eram pequenas e médias empresas, e 63\% dos acordos tinham múltiplos lotes, facilitando o acesso das PMEs (OCDE, 2018, p. 173). No Chile, Burr-Ortuzar et al. (2017, apud EBRD, 2017) também encontraram que a probabilidade de participação de pequenas e médias empresas caía à medida que o valor da compra subia.

Assim, parece haver um delicado balanceamento a fazer entre a obtenção de ganhos de escala e o fomento à participação e competição nos certames licitatórios. Sabemos que a definição de lotes (ou itens) é uma arte (Grimm et al., 2006), e que os ganhos de escala e estruturas de oferta variam de mercado para mercado. Mas deve-se atentar às novas possibilidades que uma compra coordenada com ata de registro de preço multifornecedor traria. Voltaremos a esse tema nas próximas seçôes.

ACHADO 3: As correlações negativas entre, de um lado, valores das compras ou números de compradores (médios ou totais) e, do outro lado, o número de propostas obtidas (média ou total), sugerem que compras com escala muito grande não atraem empresas pequenas, as quais não têm capacidade de atendimento para oferecer a quantidade solicitada, atender critérios de qualificação financeira ou cobrir as localidades para entrega às várias unidades participantes. Uma análise mais detalhada esclareceria ou confirmaria essas conjeturas. Sabemos que muitas compras pequenas advêm do particionamento de lotes para a formação de lotes exclusivos para MPEs, conforme manda a lei.

\section{EXPERIÊNCIA INTERNACIONAL DE COMPRAS CONJUNTAS EM GERAL E PARA A SAÚDE}

As compras colaborativas ou conjuntas são um dos instrumentos mais efetivos para reduzir custos em sistemas de saúde. A lógica, segundo Huff-Rousselle (2012) é que muitos dos insumos de saúde têm suas estruturas de oferta bastante concentrada nos mercados mundiais, em torno de grandes empresas multinacionais. A consolidação de poder de compra de vários países, bem como de organizaçóes dentro de um mesmo país, é um meio de atacar esse desequilíbrio. Nos modelos de compras conjuntas que consolidam compras extrafronteiras, os benefícios incluem: i) reduçóes de preços unitários; ii) maior garantia de qualidade; iii) redução ou eliminação de corrupção em compras; iv) escolha racionalizada por meio de seleção e padronização bem informadas; $v$ ) maior equidade entre membros; vi) maior utilidade prática no papel desempenhado pela instituição gestora do sistema; e vii) maior acesso a produtos médicos essenciais dentro de cada país participante. A autora acrescenta que muitas barreiras à implementação de um sistema de compras conjuntas multinacionais são eliminadas quando o mecanismo é estabelecido dentro de uma instituição internacional ou regional, especialmente quando os 
países-membros são vistos (e se veem) como clientes/membros da instituição, de modo que eles tenham algum senso de propriedade do mecanismo de compras.

Das quatro áreas de gerenciamento de ciclos de suprimento (seleção, compra, distribuição e uso), a compra eficiente fornece a maior oportunidade de economia de custos (Burnett, 2003). ${ }^{22}$ Porém, segundo a OMS, a compra eficiente envolve mais que simplesmente obter o menor preço - trata-se de criar um mercado saudável em que produtos de alta qualidade estão disponíveis no tempo certo por preços acessíveis e na quantidade certa. A compra estratégica compreende todas as atividades que objetivam aumentar a eficiência da compra. Elas incluem, por exemplo, atividades que minimizem compras repetitivas de baixo valor para aumentar as economias de escala e reduzir custos de transporte (WHO, 2016).

A compra estratégica colaborativa por um grupo de países compreende vários níveis de colaboração, como mostra a figura 7 . O mesmo se aplica a um sistema de saúde descentralizado como o brasileiro. No primeiro nível, em que a compra é apenas "informada", os participantes compartilham informações sobre preços e fornecedores e, numa ação mais coordenada, fazem pesquisas de mercado conjuntas, definem padróes e especificaçóes também em conjunto e monitoram os preços e o desempenho dos fornecedores. Uma ação de compras coordenadas leva, primeiro, a uma negociação conjunta e, num estágio mais avançado ou extremo, à criação de um organismo centralizado que realiza as licitações e adjudicação de contratos em favor dos seus membros.

Nesse arcabouço, podemos dizer que, no Brasil, há situações tanto de compartilhamento de informações e fornecedores como de compras conjuntas de produtos e serviços para a saúde com ou sem uma central de compras.

1. Compartilhamento de informaçôes: conforme descrito em Servo et al. (2020), o Banco de Preços de Saúde (BPS) serve para compartilhar informaçóes acerca de fornecedores e preços, e usa uma classificação comum de produtos. Os fornecedores são incluídos com seus CNPJs. Mas existem falhas de cobertura: nem todas as compras de saúde são registradas no banco. Apenas medicamentos têm

22. Tomemos o exemplo do serviço nacional de saúde britânico (NHS). Em relatório de 2013, o subsecretário de Saúde britânico calculava que o NHS gastasse mais de 20 bilhões de libras anuais em bens e serviços que respondiam por $30 \%$ dos custos operacionais de cada hospital, e que nenhum negócio conseguiria sobreviver sem um controle rigoroso de uma parcela tão substancial dos custos. As reformas então em curso já tinham conseguido economias de $€$ 1,5 bilhão com a redução de burocracia e em 2011 o Escritório Nacional de Auditoria (NAO) estimava um potencial extra de $€ 500$ milhões em economia por adoção de melhores práticas em contratações (NHS, 2013). 
registro compulsório. Além disso, o desempenho dos fornecedores não é compartilhado entre os membros, seja para ocorrências ruins (faltas ou atrasos de entrega, por exemplo), seja para uma execução irretocável dos pedidos e/ou contratos.

2. Contratação conjunta, também conhecida como compra coordenada: através do registro de preços, a União, os estados e os municípios, ou entidades destas esferas, podem comprar em conjunto numa só licitaçáo uma lista de produtos divididos em itens de compra. Em cada item, um produto bem definido (por exemplo, hipoclorito de sódio, solução aquosa, teor de $1 \%$ de cloro ativo) pode ter várias entidades compradoras (também chamadas de unidades participantes da compra ou da ata de registro de preços) com quantidades máximas solicitadas e consolidadas pelo gestor da ata, que é também o responsável pela compra (e, portanto, publica o edital, organiza o certame pregão ou concorrência e homologa o resultado, adjudicando o objeto ao vencedor ou vencedores). O gestor da ata é responsável também por sua eventual prorrogação e pela autorização do ingresso de novos membros que não participaram desde o edital, os chamados caronas.

Vimos que centralizar compras não visa necessariamente baixar preços para o serviço público. Na verdade, também não necessariamente a centralização conduz a essa redução de preços. Dubois, Lefouili e Straub (2019) resenham vários artigos teóricos que mostram em que condiçóes o preço pode ser afetado positiva ou negativamente pela formação de um pool de compradores. Por exemplo, num arcabouço com um único fornecedor, Chipty e Snyder (1999) e Inderst e Wey (2007) encontram que o pool obtém preços mais baixos se a curva de custos do fornecedor for convexa, mas os preços são maiores se essa curva for côncava. Jeon e Menicucci (2017) também encontram que o formato da curva de custo do fornecedor afeta o impacto da compra conjunta sobre preços num modelo que estende o arcabouço de agência comum (Bernheim e Whinston, 1986) para múltiplos fornecedores. Mas, diferentemente dos artigos anteriores, eles encontram que o pool não afeta preços quando os custos são côncavos. Eles demonstram ainda que, quando o custo é convexo, o efeito sobre os preços pode ser positivo ou negativo, dependendo de qual equilíbrio é selecionado. 
FIGURA 7

Níveis de colaboração

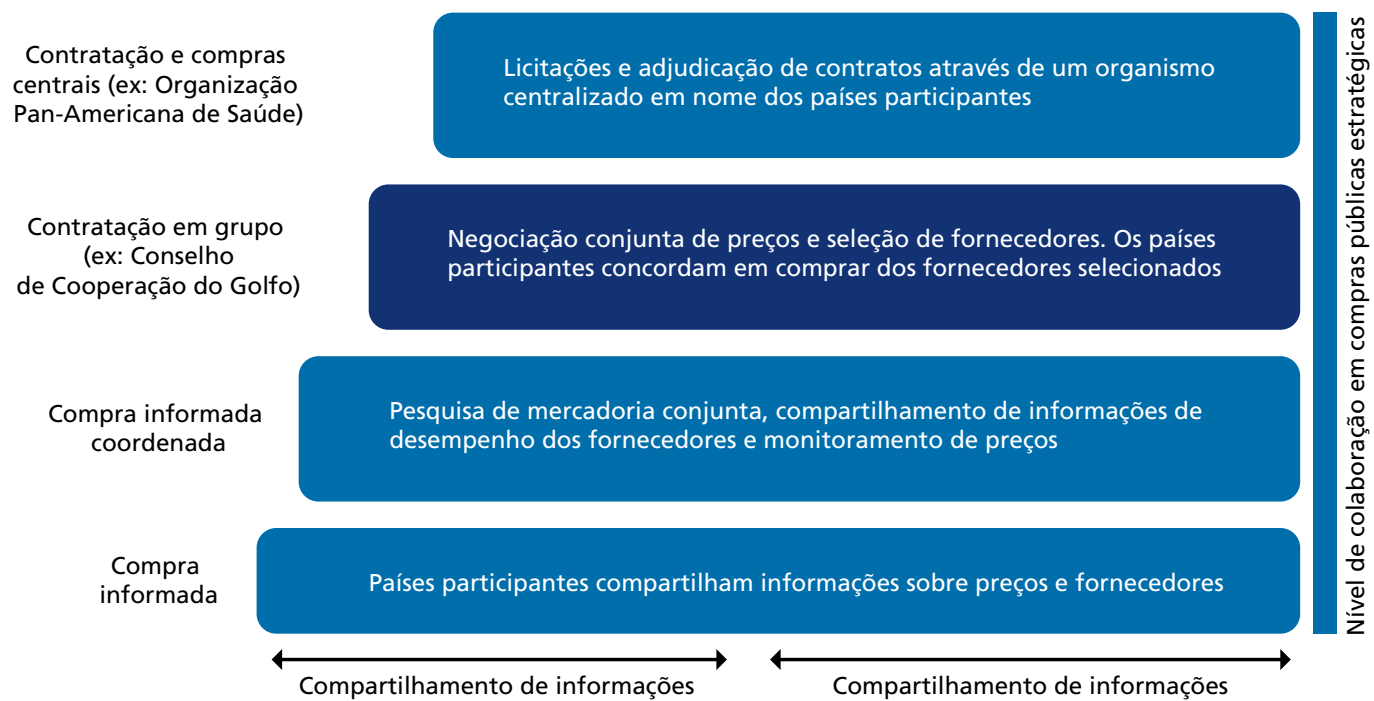

Fonte: WHO (2016)

Outro mecanismo pelo qual um pool pode não levar sempre a preços mais baixos é investigado por Inderst e Montez (2019). Neste modelo, múltiplos fornecedores e compradores se envolvem em negociações bilaterais, e os preços são determinados pela capacidade dos compradores de realocar compras entre fornecedores e pela capacidade dos fornecedores de realocar vendas entre compradores (no caso, um desacordo bilateral). Ainda neste modelo, um aumento no tamanho do comprador (por exemplo, a formação de um pool de compras) aumenta a dependência mútua entre o comprador e os fornecedores ao piorar suas opçóes de ajuste do comércio no caso de um desacordo. Essa mudança gera efeitos tanto positivos como negativos nos preços e conduz a uma previsão ambígua em relação ao impacto líquido de um pool de compradores.

Na prática, as experiências de compras centralizadas também têm efeitos variados. $\mathrm{Na}$ área de saúde, são dignas de nota experiências como as do Serviço de Medicamentos do Leste Caribenho (ECDS) no fim dos anos 1980, com nove pequenas ilhas do Caribe (Huff-Rousselle e Burnett, 1996); o Programa de Compras em Grupo do Conselho de Cooperação do Golfo (Bahrain, Kuwait, Oman, Qatar, Arábia Saudita e Emirados Árabes Unidos) - GCC/GPP; e o Fundo Estratégico da Organização Pan-Americana de Saúde (Opas), que agrupa dezessete países para a compra de vacinas. Outros arranjos multinacionais semelhantes são o Plano de Emergência do Presidente dos Estados Unidos para Combate à AIDS (PEPFAR) e o Fundo Global de Combate à AIDS, Tuberculose e Malária. 
Barbosa (2015) também cita diversas outras iniciativas de compras conjuntas ao redor do mundo. Nos Estados Unidos, a partir de 1999, quando foram aprovadas leis estaduais e ordens executivas para compras conjuntas entre diversos órgãos e governos, foram surgindo os chamados bulk buying pools, como o National Medicaid Pooling Initiative (NMPI) - onze estados mais o Distrito Federal, 2003 -, o Top Dollar Program (TOP) - cinco estados, 2005 -, o Sovereign States Drug Consortium (SSDC) - sete estados, 2005 -, o Northwest Prescription Drug Consortium (NPCD) - dois estados, 2007 -, a Minnesota Multistate Contracting Alliance for Pharmacy (MMCAP), agências e clínicas de 45 estados, fim dos anos 1990.

Espín et al. (2016) também relatam várias experiências de consórcios de compras transfronteiriços. O BeNeLuxA, por exemplo, é um consórcio reunindo Bélgica, Países-Baixos, Luxemburgo e Áustria, criado para a negociação conjunta de preços de medicamentos para doenças raras. Seus objetivos foram expandidos para uma colaboração mais ampla em prospecção e avaliação de tecnologias de saúde, intercâmbio de informaçóes sobre os mercados, preços e registros sanitários farmacêuticos para doenças específicas, bem como apreçamento e reembolso, visando assegurar acesso a drogas inovadoras, inicialmente drogas órfãs. O grupo foi posteriormente alargado pela entrada da Irlanda, ${ }^{23} \mathrm{em} 2018$. Embora houvesse bastante esperança na eficácia desse arranjo para aumentar o poder de barganha, O’Mahony (2019) aponta que divergências significativas entre os métodos de avaliação de tecnologias de saúde (ATS) entre os membros do BeNeLuxA surge como um impedimento à barganha coletiva de preços comuns e reconhecimento mútuo das ATS.

Outras iniciativas foram a dos países da Europa Centro-Oriental e Sul-Oriental, criada em 2016 e reunindo dez países para negociação conjunta, e a Romena-Búlgara para a realização de certames conjuntos. Por fim, o Acordo de Parcerias Bálticas reúne as três ex-repúblicas soviéticas do mar Báltico desde 2012 para compras conjuntas, principalmente de vacinas. Outras iniciativas são a Colaboração FINOSE, o Conselho Nórdico, o Fórum Nórdico de Farmacêuticos, o Grupo Nórdico de Apreçamento e Reembolso (NPT), ${ }^{24}$ o Grupo da Declaração de Sófia e o Grupo da Declaração de Valletta. Segundo Grubert (2018), não menos de 29 países participam dessas colaboraçôes, muitos em duas ou três alianças.

23. Disponível em: <https://beneluxa.org/about_pr>. Acesso em: 8 maio 2020.

24. Segundo Grubert (2018), o Fórum Nórdico de Farmacêuticos (NLF) foi estabelecido em 2015 pelo serviço dinamarquês de compras farmacêuticas (Amgros) e suas contrapartes da Islândia, Noruega e Suécia estão nele representadas. O NLF trabalha em estreita parceria com o NPT, que é uma colaboração informal entre as autoridades nacionais de apreçamento e reembolso. NLF e NPT compartilham conhecimento e se reúnem ao menos uma vez por ano para discutir interesses comuns. 
Ainda no contexto europeu, merece destaque a iniciativa adotada no enfrentamento de outra pandemia - a do H1N1 - que acabou por formatar um instrumento jurídico que viabiliza a coordenação e centralização de esforços para aquisição de insumos médicos. Trata-se do Joint Procurement Agreement (JPA), analisado por Araújo e Montenegro (2020). Seu objetivo é, de um lado, evitar a disputa entre potenciais compradores signatários e, de outro, coordenar as operaçóes de aquisição de insumos médicos - tanto em nível nacional como supranacional - centralizando-as na Comissão Europeia, a quem compete efetivar as compras. Para tanto, há a possibilidade de celebração de contratos diretos, com duração e quantidades já preestabelecidas, ou a contratação a partir de acordos-quadro (framework agreements). Nesse último caso, cabe à Comissão Europeia gerenciar esta celebração até que as partes interessadas firmem contratos específicos. ${ }^{25}$

As diferentes abordagens em relação às compras de produtos para a Saúde consideradas mais efetivas para aumentar a competição por preços e o acesso dos pacientes foram resenhadas no quadro 2 .

25. 0 JPA foi adotado e entrou em vigor em 2014 com a assinatura dos primeiros 18 Estados-Membros da União Europeia - em abril de 2020 já contava com 37 Estados-participantes, incluindo países ainda não pertencentes à União Europeia, como Sérvia, Albânia e Montenegro. Os objetivos do mecanismo eram garantir que vacinas e outras medidas médicas de combate a pandemias estivessem disponíveis em quantidades suficientes e com acesso garantido a todos os membros. Durante a pandemia de gripe A (H1N1), vários Estados Membros da União Europeia experimentavam dificuldades com acesso a vacinas e antivirais para a pandemia. Os problemas determinantes estavam relacionados a preço, confiabilidade, confidencialidade e flexibilidade para ajustar quantidades encomendadas para as reais necessidades de compras de vacinas e antivirais. Esses problemas também foram vistos como principais gatilhos para que o Conselho e o Parlamento Europeus pedissem à Comissão Europeia que criasse um mecanismo de compras conjuntas de vacinas, em vista do risco de uma potencial pandemia futura (Azzopardi-Muscat et al, 2016). 
QUADRO 2

Práticas de compras com maior probabilidade de levar a preços mais competitivos e maior acesso para pacientes

\begin{tabular}{|c|c|}
\hline Práticas de compras públicas & Países que utilizam a respectiva prática \\
\hline $\begin{array}{l}\text { Um órgão centralizado para negociar preços de medica- } \\
\text { mentos patenteados. }\end{array}$ & $\begin{array}{l}\text { Dinamarca, França, Grécia, Itália, Noruega, Malta, México, Espanha e } \\
\text { Reino Unido. }\end{array}$ \\
\hline Análise do mercado e produtos. & Dinamarca, França, Itália, Noruega, Espanha e Reino Unido. \\
\hline Agregação de volume em diferentes níveis. & $\begin{array}{l}\text { Brasil, Bulgária, Chipre, Croácia, Dinamarca, Inglaterra (Rei- } \\
\text { no Unido), Finlândia, Geórgia, Grécia, Hungria, Islândia, Itália, } \\
\text { Cazaquistão, Quirguízia, Letônia, Lituânia, Malta, Polônia, Portugal, } \\
\text { Moldávia, Bósnia e Herzegovina, Romênia, Rússia, Sérvia, Eslovênia, } \\
\text { Espanha (várias regiões), Tajiquistão, Ucrânia, Reino Unido. }\end{array}$ \\
\hline $\begin{array}{l}\text { Envolvimento do corpo clínico no processo de aquisição } \\
\text { para garantir que os produtos adquiridos estejam em } \\
\text { consonância com as necessidades clínicas e desenvolvi- } \\
\text { mento de novas orientações clínicas antes da introdução } \\
\text { dos novos produtos. }\end{array}$ & Dinamarca, Itália, Noruega, Escócia (Reino Unido) e Suécia. \\
\hline Utilização de acordos-quadro com fornecedores. & $\begin{array}{l}\text { Bélgica, Bulgária, Croácia, Tchéquia, Dinamarca, Finlândia, } \\
\text { França, Grécia, Hungria, Islândia, Itália, Noruega, Portugal, Bósnia e } \\
\text { Herzegovina, Romênia, Eslovênia, Espanha, Reino Unido e Estados Unidos. }\end{array}$ \\
\hline $\begin{array}{l}\text { Licitação no nível } 4 \text { da ATC (classificação anatômico- } \\
\text {-terapêutica) - concorrência de análogos. }\end{array}$ & $\begin{array}{l}\text { Bélgica, Bulgária, Chipre, Dinamarca, França, Hungria, Lituânia, Noruega, } \\
\text { Polônia, Eslovênia, Reino Unido. }\end{array}$ \\
\hline Contratos de preço-volume para medicamentos caros. & Dinamarca, França, Itália, Lituânia e Espanha. \\
\hline Agências internacionais de compras. & $\begin{array}{l}\text { GDF, Programa das Nações Unidas para o Desenvolvimento (PNUD), } \\
\text { Fundo das Nações Unidas para a Infância (UNICEF), Agência das Nações } \\
\text { Unidas para os Refugiados da Palestina no Oriente Próximo (UNRWA). }\end{array}$ \\
\hline
\end{tabular}

Fonte: WHO (2016).

Por fim, um relatório relativamente recente da OMS resenhou as evidências empíricas do efeito do uso de licitaçóes em compras de medicamentos (WHO, 2016). O estudo alerta, no entanto, que não é trivial a comparação dos achados sobre o impacto dos diferentes métodos de compras, devido, por exemplo, à variedade de objetivos, foco geográfico e terapêutico, período estudado e métodos de análise presentes nos estudos. Essa resenha, baseada numa busca exaustiva por palavras-chave e classificadores $\mathrm{MeSH}$ (usados na base PubMed), foi por nós complementada para incluir estudos sobre preços de dispositivos médicos, e também atualizada. Além disso, reforçamos alguns achados 
dos estudos já resenhados. ${ }^{26} \mathrm{O}$ resultado com o total de 26 estudos encontra-se no quadro A.1 (apêndice A).

O que esses estudos nos mostram?

\section{1) Efeitos da centralização/coordenação em preços:}

Em primeiro lugar, pode-se dizer que a expectativa de que o alto volume seja pré-requisito para a obtenção de preços mais baixos nem sempre se confirma.

a) menores preços: nos estudos de 5 a 10 e 16 a 19, encontrou-se que a agregação de compras contribuía para menores preços;

b) preços mais competitivos, mesmo em encomendas de volumes relativamente baixos (estudo 11). A explicação levantada pela WHO (2016) era a que outros fatores (variáveis omitidas) estariam afetando os resultados de compras além do volume e poderiam modificar o efeito do volume sobre preços;

c) efeito negativo do volume nos preços é mais pronunciado em produtos de referência (estudo 8 sobre ARVs);

d) correlaçáo insignificante entre preços e volumes de vacinas na Itália (estudo 12) e ARVs em vários países (estudo 25): no último caso, menores preços advindos da formação de consórcios de compras. O estudo 25 utiliza dados do Global Fund Purchase, da OMS e do Global Price Reporting Mechanism (GPRM), com 7.253 transaçôes de doze antirretrovirais em 24 formas diferentes de dosagens, mostrou que os consórcios trouxeram aos compradores menores preços, porém foi constatada uma fraca associação entre baixo preço pago e alta quantidade comprada (isto é, a elasticidade de preço não é estatisticamente significante). A conclusão foi que potenciais reduçóes de preços advindas de um sistema de compras conjuntas podem ser bastante limitadas e não compensar os custos de implantação do sistema.

A hipótese levantada pela WHO (2016) para a insignificância da relação entre preço e volume era a que outros fatores (variáveis omitidas) estariam afetando os resultados de compras além do volume e poderiam modificar o efeito do volume sobre preços;

26. Nota-se que os estudos resenhados pela OMS estavam reunidos em tabelas diferentes, de acordo com o efeito que estava sendo resenhado. Como muitos deles traziam mais de um efeito, a cada efeito que o documento compilava, eram repetidas as referências com novas numerações. Neste estudo, objetivando uma síntese mais apertada, consolidamos as várias tabelas numa só, mas, devido a essa multiplicidade de efeitos em alguns estudos, seria impossível ordenarmos esses estudos por um único critério, razão pela qual achamos contraproducente refazer essa ordenação, mesmo após acrescentarmos nossas próprias resenhas. Ressalte-se que as próprias citações originais da OMS não seguiam uma única sequência por causa dessa citação de efeitos múltiplos analisados em alguns artigos. 
e) mitigado pela presença de maus pagadores no pool. Seria o caso do estudo 10, que explora a presença de estados em atas de registro de preços como indicadores de maus pagadores, aumentando o prêmio de risco dos fornecedores e, portanto, os preços de reserva e os resultantes preços de equilíbrio obtidos nas licitaçóes;

f) o requisito de pré-qualificação é crucial para atrair fornecedores internacionais e, assim, baixar preços (estudos 1 e 26);

g) negativo, mesmo com produtos patenteados, por meio das negociações centralizadas (estudos 7 e 23). No México (estudos 7 e 23), a agregação de compras estudada foi de medicamentos patenteados, por meio de uma negociação centralizada, e os efeitos negativos sobre preços e gastos foram significativos;

h) preços de Central-Armazém são menores que os obtidos no marketplace e menores ainda que os obtidos nas licitaçôes descentralizadas; a diferença é maior quanto maior a concentraçáo da oferta do produto (maior o grau de monopolizaçáo) - estudo 17.

No Chile, há uma central de compras e abastecimento no Ministério da Saúde, a Cenabast, que respondia no início da década de 2010 por cerca de $50 \%$ das compras de saúde do país. Com toda essa escala de compras, os preços obtidos pela Cenabast eram menores que os das licitaçóes descentralizadas e que os das compras feitas por Convênio Marco (um sistema de acordos-quadro com algumas semelhanças ao SRP brasileiro). ${ }^{27}$ Os compradores públicos podem, portanto, fazer seus pedidos diretamente à Cenabast se tivessem uma demanda firme e, assim, obter menores preços, ou, se houver necessidade imediata do medicamento, podem recorrer ao marketplace dos convênios marcos, o chamado Mercado Público. Náo estando o produto desejado disponível no marketplace, ele pode então fazer sua própria licitação ou, se ela for deserta, fazer uma contratação direta (tracto direto) (figura 8).

O estudo 17 mostra ainda que os preços da Cenabast são menores que os obtidos no Mercado Público e menores ainda que os obtidos nas licitaçóes descentralizadas, e essa diferença é maior quanto maior a concentração da oferta do produto (maior o grau de monopolização). Não está claro se os fretes da Cenabast estão computados nesta comparação. Também não entram nessa comparação os custos de manutençáo de estoque do comprador individual quando ele compra por meio da Cenabast. Mas, abstraindo esses custos possivelmente não computados, note-se que o funcionamento dos convênios marcos já foi criticado pela Organização para a Cooperação e Desenvolvimento Econômico - OCDE (2017), pois eles são multifornecedores, aceitam uma quantidade excessiva de fornecedores no

27. Discutiremos mais profundamente o atual Sistema de Registro de Preços brasileiro na seção 5. 
primeiro estágio e não procedem certames de segundo estágio; consequentemente náo há suficiente concorrência no primeiro estágio e muito menos no segundo. A padronização das compras, numa visão geral (não restrita a medicamentos) foi considerada insuficiente pela OCDE. Esse arcabouço institucional não favorece, portanto, a obtenção de preços baixos no âmbito do Mercado Público;

i) compras semicentralizadas tiveram sinal ambíguo: redução de preço (estudo 16) ou aumento (estudo 21). Bons compradores têm pouco ou nada a ganhar com agregação de compras em um nível centralizado ou semicentralizado.

O modelo de centralização de compras de saúde é discutido nos estudos 16 e 21 . No primeiro estudo, comparam-se três modelos: um centralizado, um descentralizado e um híbrido; o primeiro e o último modelos dominam em eficiência o segundo. Assim como nos estudos 13 e 15, comenta-se que a qualidade institucional é de suma importância para o êxito nas compras independentes de cada órgáo, de modo que bons compradores têm pouco ou nada a ganhar com a agregação de compras em um nível centralizado ou semicentralizado. $\mathrm{O}$ estudo 21 também compara um modelo centralizado com um semicentralizado em dois estados indianos; o sistema semicentralizado estudado apresentou bastantes fragilidades nas regras dos leilóes e no controle das ordens de compras; e

j) efeitos de licitações eletrônicas: o estudo 6 avaliou o impacto das licitaçóes eletrônicas nos preços de medicamentos no Chile. Uma das suas hipóteses era que os preços de medicamentos e dispositivos médicos diminuíam com um aumento do número de licitantes. Como a plataforma ChileCompra atrai mais fornecedores aos certames, isso leva a uma economia indireta. $\mathrm{O}$ estudo encontrou que a maior agregação de encomendas levou a preços mais baixos em $2,8 \%$, e que assim mais licitantes resultaram em preços menores, mas também encontrou que o número de licitantes parou de crescer depois de 2004, ano em que o uso da plataforma se tornou obrigatório. Esse estudo foi o único encontrado a indicar a existência de um efeito benéfico específico da plataforma.

\section{2) Efeitos da centralização/coordenação em despesas:}

a) menor despesa em comparação às compras com preços de atacado pagos pelas farmácias (estudos 4 e 22) ou às despesas previstas (estudo 24). É importante, no entanto, notar que a introdução de estruturas de compra centralizada no Chipre, na Dinamarca e na Grécia foi associada a outras reformas na organização das licitaçôes, seleção de medicamentos etc., que provavelmente contribuíram para a baixa despesa; e

b) negativo, mesmo com produtos patenteados, por meio das negociaçóes centralizadas (estudos 7 e 23). 


\section{3) Efeitos da centralização/coordenação em estoques:}

O estudo 8 também investigou o impacto da agregação de volume de vários municípios sobre o nível de estoques. Foi constatado que o número de itens em falta nos estoques por pelo menos um dia caiu aproximadamente 12\% de 2007 a 2008 (ano em que o consórcio começou a ser formado) e 48\% em 2009. O número de medicamentos indisponíveis por mais de noventa dias decresceu de onze para três em 2008 e dois em 2009.

4) Chaves para o sucesso de compras de dispositivos (estudos 13 e 15):

a) qualidade institucional do órgão comprador; e

b) relação entre pessoal administrativo e pessoal de linha de frente

Os estudos 13 e 15 analisaram determinantes institucionais para o sucesso de compras de dispositivos médicos com variados graus de complexidade e tecnologia na Itália (no estudo 5, comparou-se a decisão de licitar com a decisão de compra direta). A qualidade institucional do órgão comprador e a relação entre o pessoal administrativo/financeiro e o pessoal de linha de frente (equipe médica) são apontados como determinantes nos dois estudos.

\section{5) Efeitos das regras de leilões sobre os preços:}

a) regras de leilóes também foram comparadas no estudo 20. Neste e nos estudos $2 \mathrm{e}$ 3 , confirmou-se empiricamente a predição teórica de que o aumento do número de competidores diminui os preços (estudos 2 a 4);

b) impacto negativo da licitação sobre preços obtidos, de medicamentos, tanto patenteados como fora de patente: o estudo 4 limitou-se a analisar o impacto negativo da licitação sobre os preços obtidos de medicamentos, tanto patenteados como fora de patente.

\section{FIGURA 8}

Prioridade de compra para compradores públicos no Chile
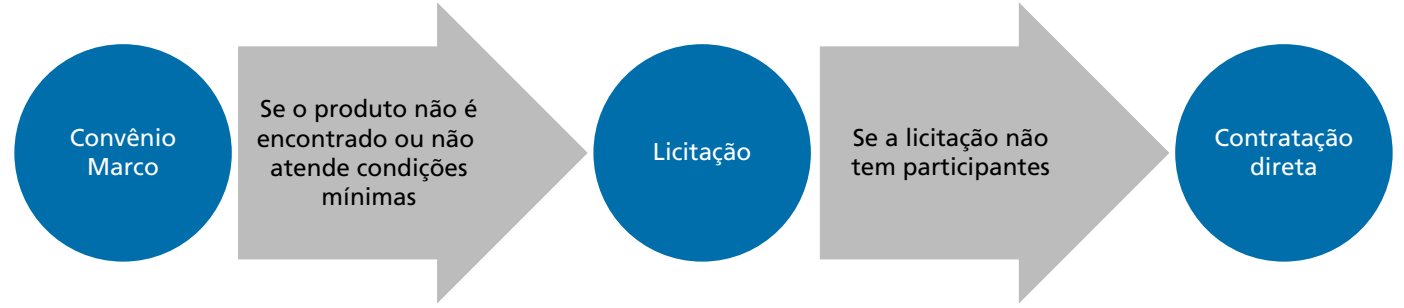
Para o que propomos mais adiante, esses resultados empíricos e a resenha da experiência internacional reforçam nossa percepção de que o foco de uma articulação institucional para as compras coordenadas não deve ser tanto a redução de preços, que depende não só do volume, mas de vários fatores institucionais. Coordenar compras significa criar um ambiente seguro e harmônico para que o sistema público de saúde garanta o suprimento confiável e tempestivo de seus insumos, fazendo estoques e centralizando logística apenas dos insumos mais estratégicos, e facilitando que os compradores tenham acesso a fornecedores com agilidade, e com a burocracia reduzida ao mínimo. A centralização excessiva pode ser deletéria se concentrar demais o mercado. A aquisiçáo de medicamentos e insumos de saúde com alto grau de complexidade exigem um corpo técnico qualificado, e a discricionariedade dada aos profissionais de compras é proporcional à sua qualidade e integridade. De fato, Bosio et al. (2020) postulam que a regulação é eficaz em países com baixa capacidade do setor público, e danosa em países com alta capacidade do setor público, porque inibe o exercício ótimo da discricionariedade. Eles encontram evidências largamente consistentes com essa predição: a regulação das compras públicas melhora os resultados dessa atividade, mas somente nos países com capacidade baixa do setor público. Dentro de países, a importância da capacidade técnica e da integridade também explica diferentes resultados (Decarolis et al., 2020).

Desse modo, falar em compras coordenadas implica buscar os melhores profissionais, colocá-los em órgáos, agências ou empresas autônomas e com mandato para coordenar as compras. Esses profissionais devem ser alinhados com os devidos incentivos e a eles devem ser dadas as devidas ferramentas para compras bem-feitas, rastreáveis, transparentes e ágeis. Resguardada essa transparência e a accountability, a busca do resultado deve superar a preocupação com o processo. Ademais, o êxito dessa coordenação de compras para as partes envolvidas requer o esforço de articulação e orquestraçáo de cada uma delas (órgãos, entes, poderes, unidades de compras etc.).

É necessário, portanto, um arcabouço misto e flexível, permitindo diferentes graus de centralização e agregação, algo que o SRP não nos oferece atualmente e não há perspectiva de oferecer no novo arcabouço de compras públicas previsto no Projeto de Lei no 1.292/1995, em tramitação no Congresso Nacional (Fiuza e Rauen, 2019) - ver também seção 5 . 


\section{MEDIDAS DE ENFRENTAMENTO À COVID-19 E A CONSTRUÇÃO DE ARCABOUÇO LEGAL PARA UM NOVO SISTEMA DE COMPRAS COORDENADAS (ACORDO-MARCO)}

\subsection{A sistemática vigente para dispensa de licitações e compras emergenciais}

Como regra geral, toda contratação efetivada pela administração pública no Brasil deve ser precedida de regular procedimento licitatório. É o que dispóe a Constituição Federal em seu art. 37, inciso XXI. A contratação direta é, portanto, medida excepcional, admitida apenas nas hipóteses previstas em lei.

A legislação geral de licitaçóes e contratos prevê expressamente a hipótese de dispensabilidade do procedimento regular licitatório na hipótese de ocorrência de calamidade ou emergência pública. Dispóe o inciso IV do art. 24 da Lei Federal no 8.666/1993, aplicável às três esferas de governo:

É dispensável a licitação:

IV - nos casos de emergência ou de calamidade pública, quando caracterizada urgência de atendimento de situaçáo que possa ocasionar prejuízo ou comprometer a segurança de pessoas, obras, serviços, equipamentos e outros bens, públicos ou particulares, e somente para os bens necessários ao atendimento da situação emergencial ou calamitosa e para as parcelas de obras e serviços que possam ser concluídas no prazo máximo de 180 (cento e oitenta) dias consecutivos e ininterruptos, contados da ocorrência da emergência ou calamidade, vedada a prorrogação dos respectivos contratos;

É importante notar que, para que ocorra a contratação direta, por dispensa de licitação, é necessária a ocorrência concomitante de alguns fatores, sendo estes requisitos necessários para celebração do ajuste contratual. $\mathrm{O}$ primeiro diz respeito à demonstração da imprescindibilidade e essencialidade das contrataçóes, que devem ser justificadas a partir da caracterização da situação emergencial, calamitosa ou de grave e iminente risco à segurança pública que justifique a dispensa. Em segundo lugar, no que se refere à abrangência, a contratação poderá servir somente para o atendimento da situação emergencial ou calamitosa e para etapas ou parcelas de obras e serviços que possam ser concluídas no prazo máximo de 180 dias consecutivos e ininterruptos, contados da ocorrência da emergência ou calamidade, não se permitindo, pela lei, renovaçóes. Finalmente, há que se observar também os requisitos formais previstos no art. 26 da mesma lei, que incluem 
a explicitaçáo da razão da escolha do prestador de serviço e a justificativa do preço e a publicação do ato de dispensa na imprensa oficial.

Além dos requisitos legais previstos na Lei no 8.666/1993, o Tribunal de Contas da União (TCU) tem firmado entendimentos relevantes à administração pública no tocante a esta matéria. Se, por um lado, tem adotado postura flexibilizadora em relaçáo ao prazo máximo de 180 dias (por exemplo, no Acórdáo nº 3.238/2010-Plenário); por outro, tem ampliado as exigências para caracterização da situação de dispensa, com caráter normativo. Dois julgados são emblemáticos. Na Decisão no 347/1994-Plenário, firmou-se o entendimento de que a situaçáo adversa, dada como de emergência ou de calamidade pública, não pode ter se originado, total ou parcialmente, da falta de planejamento, da desídia administrativa ou da má gestão dos recursos disponíveis, ou seja, que ela náo possa, em alguma medida, ser atribuída à culpa ou dolo do agente público que tinha o dever de agir para prevenir a ocorrência de tal situação. O entendimento foi significativamente alterado no Acórdáo oㅗ 1.876/2007, quando o tribunal afirmou que a situação prevista no art. 24, VI, da Lei no $8.666 / 1993$ não distingue a emergência real, resultante do imprevisível, daquela resultante da incúria ou inércia administrativa, sendo portanto cabível, em ambas as hipóteses, a contratação direta, desde que devidamente caracterizada a urgência de atendimento da situação que possa ocasionar prejuízo ou comprometer a segurança de pessoas, obras, serviços, equipamentos e outros bens, públicos ou particulares. No entanto, para caracterização da incúria ou inércia administrativa, não se pode falar de situaçôes genéricas, sendo necessária a individualização da culpa, em relação ao comportamento individual de determinado agente público.

Além das decisões anteriores que apresentam formas distintas da Corte de Contas considerar justificativas quanto à causa da situaçáo emergencial, a Decisão no 627/1999 (Plenário) também é de grande relevância, pois trouxe detalhamentos significativos para a escolha do fornecedor, de especial interesse para este texto. São eles os seguintes.

1) Justificativa fundamentada da escolha do fornecedor ou executante, conforme o art. 26, parágrafo único, inciso II, da Lei no 8.666/1993, sempre que possível com base em elementos que demonstrem que esse: $i$ ) possui capacidade técnica compatível com a complexidade e o porte do objeto a ser contratado e atende aos requisitos relacionados à habilitação jurídica e à qualificação econômico-financeira; e ii) encontra-se em situação de regularidade com a Seguridade Social, nos termos da Decisão nº 705/1994 Plenário.

2) Justificativa do preço, de acordo com o art. 26, parágrafo único, inciso III, da Lei $\mathrm{n}^{\mathrm{o}}$ 8.666/1993), mediante a verificação da conformidade de orçamento do fornecedor 
ou executante, juntado ao processo de dispensa de licitação, com os preços correntes no mercado ou fixados por órgão oficial competente ou ainda com os constantes do sistema de registro de preços, devendo também no caso específico de compras, ser dada a publicidade de que trata o art. 16 da mencionada lei.

Portanto, o TCU firmou entendimento segundo o qual, embora seja possível a dispensa do procedimento licitatório, a escolha do fornecedor e a justificativa do preço devem seguir critérios análogos, em alguma medida, aos procedimentos gerais licitatórios regulares. Nesse ponto, são relevantes as inovações trazidas pela Lei Federal n ${ }^{\circ}$ 13.979/2020, que dispóe sobre medidas excepcionais para o enfrentamento da emergência em saúde decorrente da Covid-19, e suas alteraçóes posteriores.

\subsection{As inovações trazidas pelas medidas de enfrentamento à Covid-19 (Lei $\mathrm{n}$ - 13.979/2020 e alterações posteriores)}

No dia 30 de janeiro de 2020, a OMS declarou emergência em saúde pública de importância internacional e, logo na sequência, ato do governo federal brasileiro reconheceu mesma situação em âmbito nacional. ${ }^{28}$ Poucos dias depois, em 6 de fevereiro, foi sancionada a Lei $\mathrm{n}^{-}$13.979, dispondo sobre as medidas para enfrentamento da emergência de saúde pública. Além de disciplinar medidas como isolamento social e quarentena, a legislação já tratava de alteraçôes das regras gerais de contratação para o enfrentamento da pandemia. A ela se sucederam diversas inovaçóes normativas, seja por meio de medidas provisórias (MPs) que alteraram o texto da Lei no 13.979 , como as MPs $\mathrm{n}^{\text {os }} 926$ e 951, seja por MP que alterou outros normativos relacionados às compras públicas, como a MP n⿳0 961, que autorizou pagamentos antecipados nas licitaçóes e nos contratos, aumentou os limites de dispensa de licitação em razão do valor e ampliou o uso do Regime Diferenciado de Contrataçóes Públicas (RDC) durante o estado de calamidade. Até Emenda Constitucional (EC) tratando do tema foi promulgada. A EC no 106, de 7 de maio de 2020, dentre outras medidas referentes ao regime extraordinário fiscal, dispensou a demonstração de regularidade com a Seguridade Social para contrataçóes com o poder público durante o período de calamidade.

Necessária se faz, portanto, uma análise destas alterações para o objeto deste texto. Primeiramente, apesar de se tratar de lei federal, a Lei no ${ }^{\circ}$ 13.979/2020 é uma regra cogente aplicável às pessoas jurídicas de direito público interno, federal, estadual, distrital e municipal, e aos entes privados e às pessoas naturais, conforme art. $2^{\circ}$ do Decreto $\mathrm{n}^{\circ}$

28. Portaria do Ministério da Saúde № 118, de 3 de fevereiro de 2020. 
10.282/2020 que a regulamenta. Ou seja, tem abrangência nacional no que se refere a contrataçôes públicas, tal qual a Lei no 8.666/1993.

Em seu art. 4ํㅜㄹ a Lei no 13.979/2020, com a redação dada pela MP no 926/2020, prevê uma nova hipótese de dispensabilidade de licitação, temporária e específica, aplicando-se apenas enquanto perdurar a emergência de saúde pública decorrente da Covid-19. Trata-se de uma simplificaçấo do procedimento de dispensa visando dar a celeridade necessária ao enfrentamento da crise. Dentre as inovaçôes em relação ao regime do art. 24, IV da Lei no 8.666/1993, destaca-se inicialmente que alguns de seus requisitos autorizadores encontram-se legalmente presumidos. São eles: a ocorrência de situação de emergência; a necessidade de pronto atendimento da situação de emergência, a existência de risco à segurança de pessoas, obras, prestaçáo de serviços, equipamentos e outros bens, públicos ou particulares; e a limitação da contratação à parcela necessária ao atendimento da situaçáo de emergência. Estes requisitos encontram-se presumidamente atendidos, independente de demonstração específica em cada caso.

Adicionalmente, se a autoridade competente verificar restrição de fornecedores ou prestadores de serviço, poderá, mediante justificativa, dispensar a apresentação da documentação relativa à regularidade fiscal e trabalhista ou, ainda, o cumprimento de um ou mais requisitos de habilitação. Será possível ainda a contratação de fornecedora de bens, serviços e insumos de empresas que estejam com inidoneidade declarada ou com o direito de participar de licitação ou contratar com o poder público suspenso, quando se tratar, comprovadamente, de única fornecedora do bem ou serviço a ser adquirido.

O termo de referência ou projeto básico poderão ser simplificados. As estimativas dos preços poderão ser obtidas por meio de, no mínimo, um dos seguintes parâmetros:

- portal de compras do governo federal;

- pesquisa publicada em mídia especializada;

- sítios eletrônicos especializados ou de domínio amplo;

- contrataçóes similares de outros entes públicos; ou

- pesquisa realizada com os potenciais fornecedores

No entanto, excepcionalmente, essa estimativa de preços poderá ser dispensada mediante justificativa. A existência de estimativas de preços, todavia, náo impede a contratação pelo poder público por valores superiores, decorrentes de oscilaçóes ocasionadas pela variação de preços, desde que também justificadas. 
As alterações trazidas pela MP n 926/2020 trouxeram ainda a figura de um "pregão simplificado", sujeito a regras distintas das estipuladas pela Lei no 10.520 , com prazos previstos reduzidos pela metade e dispensabilidade da realização de audiência pública.

No que se refere ao prazo, os contratos terão prazo de duração de até seis meses prorrogáveis por períodos sucessivos, enquanto perdurar a necessidade de enfrentamento dos efeitos da situação de emergência de saúde pública. Além disso, está prevista também a possibilidade de alteração unilateral quantitativa, isto é, a administração pública poderá prever que os contratados fiquem obrigados a aceitar, nas mesmas condiçóes contratuais, acréscimos ou supressôes ao objeto contratado, em até $50 \%$ do valor inicial atualizado do contrato, inovando assim nesse aspecto quantitativo.

A grande novidade, no que se refere ao âmbito deste texto, das medidas referentes ao enfretamento à Covid-19 veio com a alteração seguinte no ordenamento das compras públicas. No dia 15 de abril de 2020, foi editada nova MP alterando a Lei no 13.979 : a MP no 951/2020. A principal inovação foi a permissão da utilização do SRP nas contrataçôes feitas por dispensa regidas pela lei. De acordo com a redação atual, caso a contratação direta interesse a mais de um órgão ou entidade, o SRP poderá ser utilizado. Nesse caso, se o ente federativo não dispuser de regulamento específico, poderá adotar a regulamentação federal da matéria - o Decreto Federal no 7.892/2013. Ainda, caberá ao gerenciador da compra estabelecer prazo, de dois a quatro dias úteis, contados da data de divulgação da intenção de registro de preço, para que outros órgãos e entidades manifestem interesse em participar do SRP. A mudança permite, assim, que as compras compartilhadas entre órgãos e entidades públicos ganhem nova dimensão. Finalmente, ainda de acordo com as alteraçóes feitas pela MP no 951/2020, as referidas operaçóes, realizadas por meio do SRP, serão consideradas compras nacionais, tais quais definidas na seção anterior, o que traz relevantes consequências na sistemática e nos limites quantitativos a elas aplicável. Em suma, a MP no 951/2020 constrói uma importante ponte entre o SRP e a dispensabilidade de licitaçóes, ampliando ainda o potencial dos pregóes para registro de preços, mas não trata os pontos nevrálgicos dessa sistemática, mencionados anteriormente. Antes de explorarmos esse ponto, convém repassar de forma sucinta a evolução do SRP em nosso ordenamento jurídico, previsto expressamente com esse nome no direito brasileiro em 1986, mas já existente desde o início do século passado.

\subsection{Histórico do SRP no ordenamento brasileiro}

O Código de Contabilidade da Uniāo, consubstanciado no Decreto n 4.536 de 1922, já trazia, em seu art. 52, a possibilidade da efetivação de um cadastro de negociantes 
na contabilidade dos ministérios e demais repartiçôes interessadas, com o objetivo de fornecimento de bens de consumo habitual, a partir de preços preestabelecidos, com validade não inferior a quatro meses. ${ }^{29}$

Posteriormente, com a ediçáo do Decreto-Lei no 2.300/1986, diploma que passou a reger à época as licitaçóes, o SRP foi previsto de maneira expressa, destacando-se, porém, o critério de conveniência e oportunidade da administração pública em sua utilização. ${ }^{30}$ O normativo foi regulamentado pelo Decreto no 449/1992, que criou o Sistema Integrado de Registro de Preços (Sirep), o qual deveria orientar o gestor na verificação da compatibilidade da proposta com os preços praticados no mercado.

Com o advento da Lei de Licitaçóes e Contratos, Lei no 8.666/1993, o SRP não só foi mantido como lhe foi dado um caráter de compulsoriedade. Sempre que possível, deveria ser utilizado, desaparecendo assim do texto legal a menção à conveniência do gestor. ${ }^{31}$ Noutras palavras, não se trata de uma faculdade do gestor, pois sempre que for cabível - e as hipóteses de cabimento são aquelas previstas no regulamento - ele deverá ser aplicado. Entretanto, o sistema, como se verá adiante, não obriga a administração a contratar aquele que registrou o preço, garantindo, apenas, a preferência em igualdade de condiçóes, tendo por objetivo facilitar contrataçóes futuras. Assim, a compulsoriedade da adoção do SRP, sempre que possível, não se confunde com a obrigatoriedade de a administração contratar o vencedor.

29. Decreto no 4.536/1922, art. 52. Para os fornecimentos ordinarios ás repartições publicas, poderá o Governo estabelecer o regimen de concurrencias permanentes, inscrevendo-se, nas contabilidades dos Ministerios e nas repartições interessadas nos fornecimentos, os nomes dos negociantes que se propuzerem a fornecer os artigos de consumo habitual, com a indicação dos preços offerecidos, qualidade e mais esclarecimentos reputados necessarios.

$\S 1$ 1A inscripção far-se-á mediante requerimento ao chefe da repartição ou ao Ministro, conforme determinação regulamentar, acompanhado das informações necessarias ao julgamento da idoneidade do proponente, indicação dos artigos e preços dos fornecimentos pretendidos.

$\S$ 2 Julgada dentro de 10 dias a idoneidade do proponente, será ordenada a sua immediata inscripção si este se subordinar ás condições exigidas para o fornecimento.

§ 3o Os preços offerecidos não poderão ser alterados antes de decorridos quatro mezes da data da inscripção, sendo que as alterações communicadas em requerimento só se tornarão effectivas após 15 dias do despacho, que ordenar a sua annotação.

§ 4ㅇ 0 fornecimento de qualquer artigo caberá ao proponente que houver offerecido preço mais barato, não podendo, em caso algum, o negociante inscripto recusar-se a satisfazer a encommenda, sob pena de ser excluido o seu nome ou firma do registro ou inscripção e de correr por conta delle a differença. (texto original).

30. Decreto Lei no 2.300/1986, art. 14. As compras, sempre que possível e conveniente, deverão: (...) II - ser processadas através de sistema de registro de preços (grifo nosso).

31. Lei no 8.666/1993, art. 15. As compras, sempre que possível, deverão:

II - ser processadas através de sistema de registro de preços. 
Inicialmente foi regulado pelo Decreto no $2.743 / 1998$, e, a partir de 2001, pelo Decreto n 3.931. A inovação trazida pelo Decreto federal no 3.931/2001 foi a possibilidade de adesão à ata de registro de preços, tema que evolui cercado de muita controvérsia. Hoje segue regulamentado pelo atual marco legal do SRP, o Decreto Federal no 7.892/2013.

O Decreto n⿳ 7.892 define o SRP como um “conjunto de procedimentos para registro formal de preços relativos à prestação de serviços e aquisição de bens, para contrataçôes futuras". Uma divergência inicial que suscitou foi quanto ao seu âmbito de abrangência. A lei fala apenas em "compras"; já o decreto previu sua aplicação para "contratações de serviços e a aquisição de bens". Di Pietro (2018, p. 472) sustenta que, ao ampliar a utilizaçáo do SRP, o decreto exorbitou o previsto em lei, em afronta ao princípio da legalidade. O entendimento dominante, no entanto, é da aplicabilidade do SRP para contratação de serviços, que já estava prevista no Decreto no $3931 / 2001$. Nesse sentido, Justen Filho (2005, p. 148) corrobora que, ainda que a Lei no 8.666/1993 tenha se reportado apenas às compras, o diploma legal não tornou incompatível o SRP para os serviços.

As grandes controvérsias, no entanto, e as consequentes limitaçóes à sua utilização se referiram, sem dúvida nenhuma, às possibilidades de adesão tardia à ata de registro de preços. Esta ata não se consubstancia num contrato propriamente, nem se confunde com a ata de licitação na qual se relatam os acontecimentos do certame. Como definido no art. $2^{\circ}$ do Decreto $n^{-}$7.892/2013, cuida-se de um instrumento vinculativo e obrigacional, constituindo-se, assim, em um pacto para futura contratação, em condiçôes preestabelecidas, uma vez verificada a oportunidade e conveniência do órgáo público em fazê-la.

Os sujeitos participantes do SRP podem ser definidos em três grupos: órgão gerenciador, órgão participante e órgão não participante, também conhecido como "carona”, como referido anteriormente. O primeiro é aquele que possui funçóes destinadas ao controle dos procedimentos e à administração do sistema, responsabilizando-se pelo regular andamento da licitação, isto é, a condução do conjunto de procedimentos para registro de preços e gerenciamento da ata de registro de preços dele decorrente. $\mathrm{O}$ órgão participante é aquele que participa dos procedimentos iniciais do SRP e integra a ata de registro de preços. Por fim, o órgão não participante é aquele que, não tendo participado dos procedimentos iniciais da licitação, atendendo aos requisitos da norma, faz adesão à ata de registro de preços já vigente. 
Sob a lógica do Decreto federal no 3.931/2001, o aderente poderia contratar até $100 \%$ do quantitativo consignado na ata de registro de preços e não havia limites para as adesôes, gerando um número potencial ilimitado de contrataçóes. O TCU, ao analisar a matéria, expressou sua discordância em relação a essa possibilidade ilimitada de contrataçôes no Acórdão no 1.487/2007, determinando ao governo federal a revisão das normas do regulamento com a adoção de limites. Dada a inação do Executivo federal, o TCU retornou ao tema no Acórdáo no 1.233/2012, impondo, ele próprio, limites à adesão. $\mathrm{O}$ tribunal estabeleceu que todos os contratos decorrentes da ata de registro de preços não poderiam exceder a quantidade originalmente licitada e consignada em ata, isto é, globalmente considerados, gerenciador, participantes e todos os eventuais aderentes não poderiam contratar em conjunto quantidade superior à que foi licitada $\mathrm{e}$ inicialmente registrada. Desta forma, a adesão só seria possível no caso de desinteresse da entidade que promoveu a licitaçáo de adquirir todo o quantitativo registrado.

Após um pedido de reexame por parte do governo federal, o TCU permitiu que os novos limites para a adesão à ata de registro de preços somente valessem a partir de 2013, e neste ínterim, editou o Decreto no 7.892, publicado em 23 de janeiro de 2013, com um capítulo específico dedicado a regular a utilizaçáo da ata de registro de preços por órgão ou entidades não participantes. No entanto, a limitação prevista no decreto não era aquela estipulada pelo TCU, mas um limitante equivalente a cinco vezes, na totalidade das contrataçóes, do quantitativo registrado originalmente em ata.

Ainda assim, o novo decreto representou limitaçóes relevantes à carona, uma vez que estipulou que ela precisa ser autorizada pelo edital, pela entidade que promoveu a licitaçáo, justificada pelo aderente e ainda limitada a $100 \%$ do quantitativo registrado na ata para cada aderente e respeitado o limite global do quíntuplo do quantitativo previsto em ata. Alteraçáo relevante na sistemática do Decreto no 7.892 foi trazida no ano seguinte à sua edição, como a inclusão da figura da "compra nacional" pelo Decreto no ${ }^{\circ} 8.250 / 2014$. Como será visto na subseção 4.4, as compras nacionais têm o objetivo de atender às necessidades dos entes federados em programas e projetos de execuçáo descentralizada pelo governo federal. Ademais, o decreto simplificou a figura do cadastro de reserva.

Passados os anos e, percebendo-se que o "carona" ainda era uma figura a ter seu contexto de atuação reduzido, pois, muitas vezes, evidenciava uma fragilidade no planejamento das aquisiçóes e deficiência nas justificativas para solicitar adesóes pelos órgãos interessados, o Poder Executivo editou, em 2018, outro normativo impondo novas barreiras. 
O Decreto federal nำ 9.488/2018, alterou o Decreto ํㅜ․ 7.892 para prever que cada aderente somente possa contratar $50 \%$ do registrado na ata e a soma de todas as adesóes não ultrapasse o dobro do registrado na ata, ressalvada a figura da "compra nacional", que manteve os limites quantitativos anteriormente previstos. Além disso, passou-se a exigir que os órgáos e as entidades elaborassem estudos nos quais fossem demonstrados o ganho de eficiência, a viabilidade e a economicidade para a administração pública da utilização tardia da ata de registro de preços e os submetessem aos gerenciadores da ata, que deveriam aprová-los como condiçáo à autorização da carona. Importante destacar que tal exigência guardava coerência também com o Acórdáo no 311/2018, do TCU, que passou a demandar que a previsáo no edital de adesôes à ata de registro de preços fosse motivada pela entidade responsável pela licitação, não cabendo motivação genérica de economia de escala, alterando assim os incentivos dos atores do SRP. Se antes a adesão não trazia vantagens ao órgão gerenciador, também não lhe trazia desvantagens. Com este novo entendimento, cria-se um desincentivo ao órgão solicitante da carona e ao gerenciador ao exigir fundamentação e consequentemente sujeitá-lo a eventuais sançôes, reforçando assim objeções já apresentadas em se tratar o registro de preços como bem público (Barbosa, 2015). Assim, em grande medida, o Decreto no 9.488/2018 representou um significativo desestímulo à prática da adesão, ao impor obrigaçóes e responsabilidades ao gerenciador ainda maiores do que as previstas pelo TCU no acórdão de 2018. O desincentivo à entidade promotora da licitação em prever a possibilidade de adesão no edital está, de um lado, na obrigação decorrente de formular uma justificativa para tanto, e, de outro, em analisar e julgar as justificativas dos aderentes, estando passível de responsabilização por parte dos órgáos de controle por este julgamento. Por outro lado, o Decreto ㄲo 9.488/2018 ressalvou das novas restriçôes quantitativas as já referidas compras nacionais.

Por fim, nesse breve repasso da evolução do SRP em nosso ordenamento, cumpre registrar duas previsóes de SRP criadas em paralelo àquela prevista pela Lei Geral de Licitaçóes e Contratos. A primeira se refere ao SRP vinculado ao Regime Diferenciado de Contrataçóes Públicas (RDC). Esta figura está prevista no art. 32 da Lei do RDC (Lei no 12.462/2011) regulamentada nos arts. 87 a 108 do Decreto no 7.581/2011. A sistemática do SRP/RDC repetiu em muitos pontos a sistemática geral do SRP, trouxe peculiaridades inerentes aos modos de disputa do RDC e previu inovaçóes especialmente sobre limitaçōes aos caronas que vieram a ser repetidas no regulamento geral do Decreto no 7.892 em 2013. A segunda previsão em paralelo de SRP que merece registro é aquela presente na Lei das Estatais (Lei no 13.303/2016), que estipula em seu art. 66 a figura de um SRP especificamente destinado às licitaçóes por ela regidas. 
Como vemos, ao longo de sua história, o SRP tem funcionado com bastante limitaçóes. Por ter sido sempre regulamentado por decreto, haveria uma oportunidade neste momento crítico para ampliar o seu escopo, na linha do que já foi proposto em Fiuza, Pompermayer e Rauen (2019) e Fiuza e Rauen (2019). Lá se destacou que a proposta para o registro de preços contemplada na nova legislação de licitaçóes e contratos fica muito aquém do que já é empregado em outros países, notadamente os da OCDE, destacando-se o seguinte:

1) Com a exceção do que foi recém-introduzido em caráter temporário pela MP no 951/2020, o registro de preços requer procedimento licitatório, seja concorrência, seja pregão; em particular, se um produto é monopolizado, cada órgão comprador tem que fazer seu próprio processo de inexigibilidade, o que, é um contrassenso, pois deixa cada órgão sozinho à mercê de um único vendedor, em vez de os órgãos negociarem em conjunto. ${ }^{32}$

2) A adjudicaçáo de mais de um fornecedor só acontece quando o ofertante do menor preço não oferece toda a quantidade solicitada na ata.

3) O único critério de adjudicação é o menor preço, que fica fixado durante toda a vigência da ata.

4) Todas as condiçôes contratuais e especificaçōes dos bens ou serviços comuns são rigorosamente iguais para todas as unidades compradoras, tanto as que são originalmente membros da ata, como as que aderem depois (os "caronas").

5) A gestão da ata não é uma atividade remunerada, pelo contrário, enseja encargos e submete o gestor ao risco de várias penalidades.

A falta de um dispositivo que coordene as compras de produtos semelhantes dá origem a atas que concorrem entre si, frustrando, ainda que em parte, o objetivo de agregar compras e ganhar escala para o governo. A própria figura do carona é sinal de mau planejamento e também mina o poder de compra do governo, pois a quantidade licitada é menor do que a real. Ao mesmo tempo, o comportamento caronista cria conflitos derivados do fato de que náo se reconhece todos os custos de transação e o ônus administrativo e jurídico incorrido na atividade de gestão de atas.

32. Fiuza, Pompermayer e Rauen (2019) e Fiuza e Rauen (2019) manifestaram-se contra a extensão do registro de preços a casos de dispensa, como previsto no texto atual do projeto de lei de licitações (PL no 1.292/1995 aprovado pela Câmara dos Deputados). Diante das circunstâncias da pandemia, admitimos que alguns casos de dispensa são passíveis de uso do SRP, nomeadamente os casos de emergência e calamidade pública. 
Toda essa discussão ganha ainda maior amplitude quando observamos que parcela significativa de gastos governamentais frente ao produto interno bruto (PIB) dos países se refere a compras públicas. No Brasil, esse volume chegou a a12,6\% do PIB na média de 2006 a 2016 (Ribeiro e Inácio Júnior, 2019) considerando todos os entes federativos, sendo 7,1 pontos percentuais (p.p da União, 2,2 p.p. dos estados e 3,2 p.p. dos municípios.

Tais números fortalecem as discussóes acerca do potencial das compras governamentais como instrumento de política pública e melhoria do gasto público, seja otimizando processos administrativos, avaliando a vantajosidade das relaçóes de compra e fornecimento, seja fomentando práticas inovadoras ou buscando alternativas que viabilizem redução de custos e/ou ganhos de escala. Porém, ainda falta um elemento que promova tal orquestraçáo de interesses, necessidades e soluçôes, criando contextos mais colaborativos e de relação de ganha-ganha entre os diferentes entes, bem como entre os setores públicos e privados, abordagem que passamos a tratar na sequência. Essa dificuldade de coordenação entre órgáos e entidades, bem como entre entes federados e poderes, poderia ser contornada com a centralização de compras sob uma perspectiva institucional, ou seja, com uma, ou poucas, unidades criadas dedicadas a realizar licitaçóes e contrataçóes para os demais e, assim, ter uma percepção do todo demandado e orquestrar as atas de registro de preços e demais instrumentos que atendam a propósito similar. Tal iniciativa náo é uma novidade, datando de um período até bem antigo em nossa história, como veremos a seguir.

\subsection{As novas possibilidades para um sistema de compras coordenadas}

A coordenação ou centralização de compras pode ser observada sob duas dimensôes. A primeira delas condiz com o compartilhamento de compras, que no nosso direito administrativo pode ser materializado no procedimento de SRP, que permite, como mencionado antes, que o órgão gerenciador e responsável pela licitação, assim como os participantes e caronas, usufruam de benefícios como a padronização das especificaçóes, a economia de escala e o diálogo com o mercado fornecedor. A segunda refere-se ao arranjo administrativo-institucional que suporta a função compras, a partir da concentração dos esforços para licitar e contratar em uma ou em algumas poucas unidades administrativas, criando-se espaços especializados na temática, com servidores profissionalizados e dedicados e, assim, reduzindo a replicação dessas estruturas nos órgãos e nas entidades.

No caso do SRP, muitos são os órgãos e as entidades que adotam essa prática, tanto em nível federal quanto estadual e municipal, mesmo que existam as dificuldades e necessidades de melhoria antes expostas. Merece destaque no uso do desse procedimento 
a atuação do Fundo Nacional de Desenvolvimento da Educação (FNDE), autarquia que já centralizava o Programa Nacional do Livro Didático e, em 2007, passou a licitar, de maneira consolidada, as demandas de estados e municípios para o transporte e mobiliário escolar, padronizando especificaçôes e aproveitando ganho de escala, além de fomentar novas tecnologias e mercados. Tal arranjo viria dar forma ao que, em 2014, foi incorporado ao regulamento como compra nacional, por meio da qual entes subnacionais passaram a adquirir bens e serviços a partir das atas de registro de preços formalizadas pelo FNDE para execução de verbas descentralizadas pelo ente federal, reforçando o comportamento de cooperação interfederativa.

Quanto à dimensão administrativo-institucional de centralização de compras, essa já data de período ainda mais antigo em nossa história, apesar de pouco lembrado, em dois movimentos durante os governos de Getúlio Vargas, entre 1931 e 1945, marcadas por limitaçóes e resistências (Fernandes, 2015).

Décadas depois, o Ministério do Planejamento retomou iniciativas de compras de demandas agregadas na área de tecnologia da informação, ensaiando os passos de uma política de centralização que se materializou, em 2014, com a criação da Central de Compras federal, com a missão de racionalizar processos, pensar modelos de forma estratégica, fomentar práticas inovadoras, garantir qualidade nas compras e promover reduçáo de custos, fundamentada em transparência, agilidade, eficiência e sustentabilidade. A Central de Compras tem apresentado resultados expressivos, amealhando prêmios de excelência (Brasil, 2015), podendo-se destacar os projetos de compra direta de passagens aéreas, que viabilizou a compra de bilhetes diretamente das companhias aéreas nacionais, com uma economia média anual da ordem de 15\% entre 2015 e 2017 (Miranda, 2018); e o TáxiGov, que implementou um novo conceito de transporte de servidores por meio do uso de aplicativos, trazendo uma reduçáo de 60\% nessa despesa (Olaik, 2018).

Na mesma esteira, a centralização de compras tem sido experimentada, em diversos graus de intensidade e formatos, por governos subnacionais, em busca de otimizar processos e aumentar eficiência. Há relatos sobre experiências na maior parte dos estados (Santos, 2019). Fazem parte desse cenário iniciativas de agregação de demandas por meio de compras compartilhadas em consórcios públicos, especialmente na área da saúde.

A figura 9 ilustra a cronologia geral da centralização de compras no governo federal.

Verifica-se que a centralização das compras tem se mostrado tendência crescente no setor público, em especial por conta da adoçáo intensa do SRP realizado por meio de 
pregão eletrônico, assim como outras ferramentas que representam forte incremento de uso da tecnologia da informação nos processos de trabalho, garantindo gestão de informaçóes mais efetiva, em contraposição aos enormes obstáculos operacionais do passado.

FIGURA 9

Linha do tempo da centralização de compras públicas no governo federal

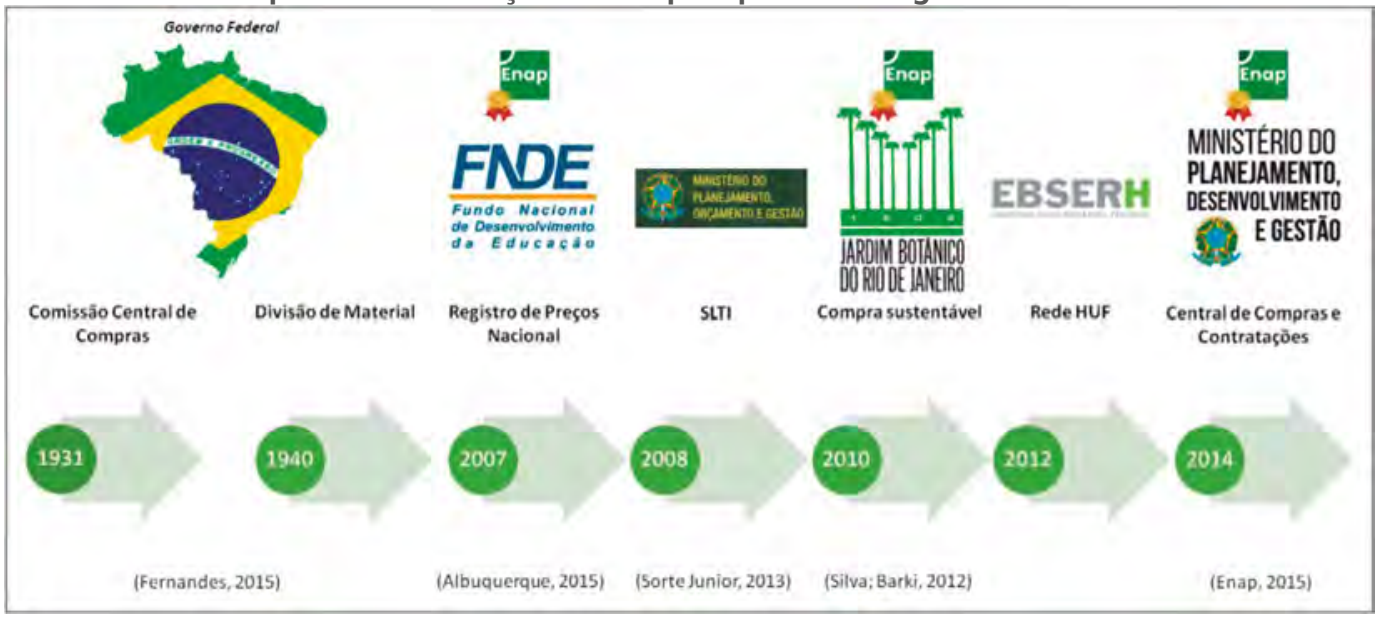

Fonte: Santos (2019, p. 62)

Corroborando esse cenário de fortalecimento das compras centralizadas, o PL no 1.292, de 1995, aprovado na Câmara dos Deputados no fim de 2019, que busca renovar substancialmente as regras de licitaçóes e contratos da administração pública, determina expressamente no art. 19, inciso I, que a centralização deve ser adotada como medida preferencial na aquisição e contratação de bens e serviços, bem como dispóe, no art. 181, que os entes federativos deverão instituir centrais de compras ou consórcios públicos, "com o objetivo de realizar compras em grande escala, para atender a diversos órgãos e entidades sob sua competência" (Brasil, 2020). Merecem registro os casos de unidades centrais de compras estaduais, em alinhamento ao que o PL pretende dar caráter obrigatório, existentes em estados como Rio Grande do Sul (Central de Licitaçôes, da Secretaria de Estado de Planejamento, Orçamento e Gestão; Sergipe (Superintendência Geral de Compras Centralizadas, da Secretaria de Estado de Administração), Mato Grosso do Sul (Superintendência de Gestão de Compras e Materiais, da Secretaria de Estado de Administração e Desburocratização); Minas Gerais (Superintendência Central de Compras Governamentais, da Secretaria de Estado de Planejamento e Gestão), Distrito Federal (Subsecretaria de Compras Governamentais, da Secretaria de Economia); Rio de Janeiro (Coordenadoria de Compras Centralizadas, da Secretaria de Estado da Casa Civil e Governança); e Santa Catarina (Diretoria de Gestão de Licitações e Contratos, da Secretaria de Estado de Administração). 
Se o mecanismo de coordenaçáo de compras por excelência no arcabouço regulatório brasileiro é o SRP, de utilização ampla pela administração pública brasileira, e ele traz graves deficiências já apontadas na seção 2 e na subseção 4.3, a discussão que se coloca como chave para resolver as deficiências de coordenação no enfrentamento à pandemia da Covid-19 passa pelo aperfeiçoamento desse mecanismo, além do aprimoramento do aparato governamental que opera as compras. Vamos, entáo, com a figura 10, entender como se insere o SRP no arcabouço mundial de compras centralizadas ou coordenadas (centralized or pooled procurement).

\section{FIGURA 10}

Tipos de acordos-quadro

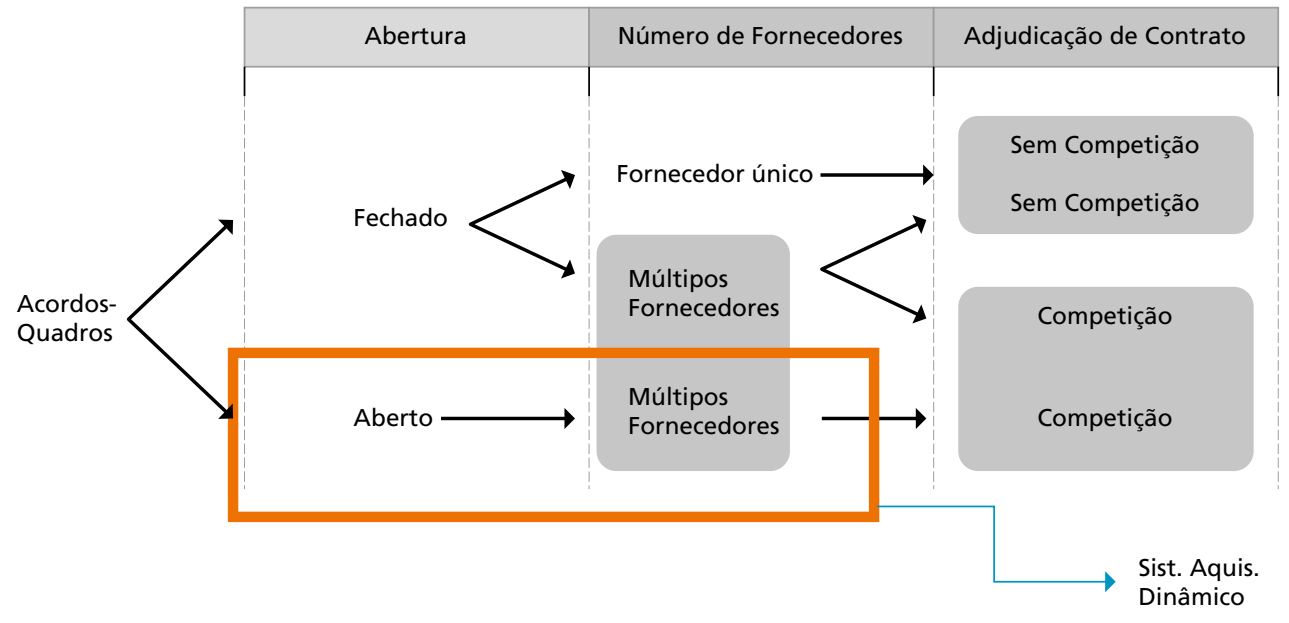

Fonte: Adaptado de Albano e Nicholas (2016).

$\mathrm{Na}$ figura 10, vemos que há no mundo uma grande variedade de práticas de compras coordenadas reunidas sob um arcabouço comum chamado acordos-quadro. Em comum, essas práticas permitem a uma ou mais entidades compradoras celebrarem um acordo guarda-chuva estabelecendo com um ou mais fornecedores a parte ou o todo das obrigaçôes contratuais de fornecimento de um bem ou serviço a qualquer momento em um prazo determinado, com ou sem diferenças nas condiçóes para essas entidades. Havendo mais de um fornecedor, o matching entre o comprador e o fornecedor a cada ordem de compra pode se dar de maneiras diferentes, que são previstas no acordo ou por algum estatuto legal ou regulatório, e definidas no acordo-quadro.

As variações principais entre os acordos-quadro são, portanto (Albano e Nicholas, 2016; Uncitral, 2011): 
- Se há restrição ao número de fornecedores admitidos ao acordo-quadro quando ele é concluído, seja por regulação, seja na prática. Isso define se o acordo será aberto ou fechado:

- fechado: uma vez celebrado o acordo-quadro, não se admitem novos fornecedores; ou

- aberto: outros fornecedores podem ser admitidos ao longo da duração do acordo.

- Quão completo é o acordo-quadro:

- completo: todos os termos e as condições para o fornecimento de bens ou serviços concernentes são estabelecidos no acordo;

- incompleto: nem todos os termos e as condiçóes para o fornecimento de bens ou serviços concernentes são estabelecidos no acordo.

- Se o uso do acordo-quadro é opcional ou obrigatório para os órgãos compradores participantes.

- Se o acordo-quadro contém ou não um compromisso vinculativo de adquirir uma quantidade mínima ou fixa.

- Se os fornecedores estão comprometidos a atender aos pedidos sob o acordo-quadro, ou a fornecer quantidades até um limite definido.

- Se são admitidos ao acordo-quadro apenas um ou mais de um fornecedor (unifornecedor versus multifornecedor, respectivamente).

A Uncitral define ainda um acordo-quadro limitado como aquele em que o número de licitantes adjudicados ou a lista de variáveis de decisão do segundo estágio são pré-definidos.

Diante de tantas possibilidades ficam algumas questôes: por que interessaria às entidades compradoras celebrar um acordo-quadro incompleto? E em que situaçóes seria interessante concluir um acordo-quadro com um único fornecedor (acordos de fornecedor único) ou com muitos fornecedores (acordos de múltiplos fornecedores)?

Quanto à primeira indagação, um acordo-quadro incompleto pode ser interessante, porque, embora seja factível (isto é, não excessivamente custoso) definir os termos principais, governando os contratos do segundo estágio no próprio texto do acordo-quadro, o órgão contratante pode decidir não o fazer para alguns elementos porque antecipa que suas necessidades variarão ao longo da duração desse acordo-quadro.

Já os acordos-quadro de um único fornecedor provavelmente serão atraentes para os fornecedores, devido à relativa certeza de que o vencedor receberá uma boa quantidade de pedidos de compra e, portanto, poderá resultar em preços competitivos. 
Por sua vez, os acordos-quadro multifornecedores dáo, em princípio, uma maior segurança de fornecimento aos compradores, uma vez que, se um fornecedor não responde a um pedido de compra, pode ser solicitado a outro fornecedor. Além disso, os acordos de multifornecedores não vinculam as autoridades contratantes (ACs) a um determinado fornecedor, mas permitem que elas façam a escolha entre diferentes fornecedores com base em procedimentos ou critérios pré-acordados específicos. Os acordos também podem ser construídos para permitir a adiçáo ou remoçáo de fornecedores ao longo do tempo.

Quando o acordo-quadro é multifornecedor, a entidade compradora, num segundo estágio, pode utilizar um minicertame com os fornecedores "credenciados" no acordo - e, diante do histórico de pouca transparência e percepção de baixo desempenho no controle da corrupção, ${ }^{33}$ a ocorrência de alguma nova concorrência é altamente recomendável e desejável. Assim, podem-se usar, em tese, todas as combinaçóes de critérios de julgamento nos dois estágios entre menor preço e técnica e preço. Pode ser o mesmo critério nos dois estágios, ou menor preço no primeiro e técnica e preço no segundo, ou vice-versa, mas a combinação de dois critérios diferentes pode trazer incentivos perversos (Albano e Nicholas, 2016).

Acordos-quadro multiadjudicados e incompletos situam-se em posição intermediária entre um contrato-quadro e um contrato simples, do ponto de vista de padronização do contrato-mestre. Isso sugere que o principal objetivo de um acrodo-quadro stricto sensu deveria ser resolver o trade-off entre padronização da demanda e eficiência processual, de um lado, e flexibilidade e eficiência alocativa, de outro.

Em outras palavras, o objetivo principal do acordo-quadro multifornecedor incompleto é agilizar o processo para compras repetidas, alocando uma porção grande do esforço geral requerido no primeiro estágio, embora deixando algum espaço para customização e mais concorrência no segundo estágio, quando as necessidades reais e suas principais características são mais bem conhecidas. Isso tem se mostrado efetivo nas centrais de compras (CPAs) que celebram os acordos-quadro para definir características básicas qualitativas ou condiçôes de preço-teto para contratos de diferentes órgãos: GSA (Estados Unidos), CCS (Reino Unido), BBG (Áustria), SKI (Dinamarca) e Hansel (Finlândia).

33. Segundo os indicadores globais do Banco Mundial, a nota do Brasil em controle de corrupção estava em 46,63 em 2018, bem abaixo da mediana mundial e da mediana latino-americana (ambas as notas em torno de 60); note-se que 0 desempenho do indicador brasileiro, anteriormente bastante próximo da mediana regional, começou a descolar-se em 2014, quando ambos os indicadores estavam em torno de 52. Também foi em 2014 que, pela primeira vez em quinze anos, a nota do Brasil deixou de ficar bem acima das medianas mundial, regional e dos países de renda média-alta, ao despencar dez pontos. Disponível em: <https://govdata360. worldbank.org/indicators/hf0ef1ed3? country=BRA\&indicator=369\&viz= line_chart\&years=1996,2018>. 
Como já se percebeu, o SRP é um caso bem particular de acordo-quadro: unifornecedor, completo e fechado. Além disso, como apontado, só admite a adjudicação do contrato mediante processo licitatório, ou seja, só contamos com a fração de uma dentre quatro possíveis combinaçóes de dimensóes de acordo-quadro. Vamos, portanto, explorar na próxima seção as possibilidades que esse arcabouço nos oferece, dentro da realidade institucional brasileira.

\section{PROPOSTAS PARA O ACORDO-MARCO}

Como vimos na seção anterior, o arcabouço institucional brasileiro só previa, até o advento da MP n⿳⺈ 951/2020, a compra de quantidades indefinidas com entrega indefinida (indefinite delivery, indefinite quantity - IDIQ, ou seja, o nosso registro de preços) junto a fornecedores selecionados por meio de concorrência, ${ }^{34}$ pregão ${ }^{35}$ ou RDC. ${ }^{36}$ A MP no 951/2020 permitiu que uma quarta modalidade de compra fosse usada: a dispensa de licitação prevista na Lei $\mathrm{n}^{-}$13.979, art. 4ํㅡ. Além disso, definiu que essas compras seriam consideradas compras nacionais.

Vale lembrar que o Decreto n⿳0 10.024/2019 atualizou a regulamentação do pregão eletrônico e previu também, no art. 51, a regulamentação da dispensa eletrônica por meio de ato normativo do secretário de Gestão da Secretaria Especial de Desburocratização, Gestão e Governo Digital do Ministério da Economia, que, no entanto, ainda não foi editado.

Por fim, vale notar que a Lei n⿳⼈ㅜㄹ 13.303/2016 (Lei de Responsabilidade das Estatais) conferiu aos gestores de compras das empresas estatais maior discricionariedade para assimilar e pôr em prática novos modelos de contratação pública. Esta lei trouxe inovações

34. Lei no 8.666/1993: art. 15. § 3ㅇ O sistema de registro de preços será regulamentado por decreto, atendidas as peculiaridades regionais, observadas as seguintes condições:

I - seleção feita mediante concorrência;

35. Lei no 10.520: art. 11. As compras e contratações de bens e serviços comuns, no âmbito da União, dos Estados, do Distrito Federal e dos Municípios, quando efetuadas pelo sistema de registro de preços previsto no art. 15 da Lei no 8.666, de 21 de junho de 1993, poderão adotar a modalidade de pregão, conforme regulamento específico.

36. Lei no 12.462: art. 29. São procedimentos auxiliares das licitações regidas pelo disposto nesta Lei:

I - pré-qualificação permanente;

II - cadastramento;

III - sistema de registro de preços; e

IV - catálogo eletrônico de padronização.

Parágrafo único. Os procedimentos de que trata o caput deste artigo obedecerão a critérios claros e objetivos definidos em regulamento. 
em matéria de compras vistas como tendências para o tema no cenário brasileiro (Heckert, Fernandes e Fenili, 2019).

A Lei de Responsabilidade das Estatais buscou aprimorar a governança das aquisiçóes no âmbito das empresas estatais brasileiras, concedendo inclusive liberdade de elaboração de regulamentos internos de contrataçóes capazes de inovar em suas licitaçóes e contratos, desde que não vislumbrada incompatibilidade com o disposto na lei. Assim, verifica-se a possibilidade de resolução interna desse desafio, viabilizando uma possível aplicação prática dos acordos-quadro de forma célere, com dependência exclusiva de evolução do regulamento interno das empresas para viabilizar essa assimilação, especialmente para ampliar a transparência do instrumento inovador.

Temos, portanto, três abordagens/estratégias legais-regulamentares possíveis, que não são mutuamente exclusivas.

1) Emendar o Decreto $n^{-} 10.024$ de modo que a regulamentação das dispensas eletrônicas se aplique também às dispensas previstas na Lei $n^{0} 13.979$.

Com esta estratégia, as dispensas com registro de preços, introduzidas na Lei no 13.979 pela MP no 951/2020, podem ser feitas eletronicamente. Associa-se a esse instrumento também um credenciamento prévio de fornecedores, nos moldes propostos por Fiuza e Rauen (2019, seção 6). A dispensa eletrônica passaria a ser, portanto, o segundo estágio do Sistema de Aquisiçóes Dinâmico, que é um caso particular dos acordos-quadro.

2) Atualizar o Decreto $n^{\circ} 7.892$ com uma regulamentação completamente nova para $o$ $S R P$ - neste caso, é necessário manter o nome de registro de preços para continuar regido pelo art. 15 da Lei no 8.666/1993 e pelo art. 11 da Lei no 10.520 no primeiro estágio e se implementar na prática o SRP previsto na Lei no 12.462 .

Com essa estratégia, se pode refazer completamente o SRP, ainda que seja com uma duração determinada e com aplicação aos eventos de calamidade e emergência. O fio condutor dessa proposta está na redação proposta para o PL no 1.292/1995 por Fiuza e Rauen (2019, seção 5). A dispensa eletrônica pode ser incorporada ao segundo estágio, de preferência com um certame simplificado semelhante à cotação eletrônica, que tem apenas uma fase de proposta (em última análise, um leilão de envelopes fechados).

3) Adotar um novo acordo-marco por meio de regulamento especifico de empresas estatais com esta atribuição, como a Ebserh, ou que venham a ganhá-la.

Esta estratégia não exige mudança em lei, mas, como depende de cada empresa estatal implementar em seu próprio regulamento e só nelas teria eficácia (a menos 
que a cada uma delas seja delegada a organização de compras para as administrações direta e indireta), tem menor alcance. Ainda assim, poderia servir de piloto para as contrataçóes públicas de bens e serviços de saúde, e inspirar a adoção das estratégias 1 e ou 2 mais à frente. $\mathrm{O}$ modelo para o acordo-marco seria, também, a redação proposta para a estratégia 2 .

Em todas as três estratégias, o comprador final terá ao seu dispor um cadastro de fornecedores pré-qualificados e prontos para atender suas ordens de compra, e poderá fazer um procedimento bastante simplificado de cotação (nas estratégias 1 e 2, uma dispensa eletrônica ou convite; na estratégia 3, um certame de primeiro preço com envelopes fechados, que também poderia se assemelhar à modalidade convite, mas restrito aos credenciados), mas preservando a transparência e a accountability.

Vale notar que esse procedimento em dois estágios foi implementado em vários países no formato de loja eletrônica, ou marketplace. Nesse tipo de arranjo, há uma plataforma, ou mercado de dois lados, mantido por um agente que intermedeia compradores e vendedores de bens e serviços. Exemplos cotidianos de plataformas no setor privado como essas são Amazon Marketplace, Uber, iFood, AirBnB, Booking.com, Alibaba e várias grandes redes de varejo que conectam compradores a fornecedores $(\mathrm{B} 2 \mathrm{C}-\mathrm{Business}$ to Consumer). Essas plataformas mantêm índices de aprovação (rating) dos fornecedores pelos consumidores, e também fazem o screening do crédito dos consumidores (recebem os pagamentos e os repassam aos fornecedores, cobrando desses uma taxa, e ou conferem a validade e segurança de seus cartóes de pagamentos). Plataformas B2B (Business to Business) têm funcionamento semelhante, sendo que as posiçóes de contratante e contratado podem se inverter, dependendo da transação mediada.

Governos também podem valer-se de marketplaces através da construção de plataformas públicas próprias ou da contratação de plataformas privadas (Nóbrega e Torres, 2020). Exemplos de marketplaces públicos também existem em países como Itália (MePA, em: <https://www.acquistinretepa.it/opencms/opencms/vetrina_iniziative.html?filter $=\mathrm{ME}>$ ), Chile (ChileCompra Express, em: $<$ https://www.mercadopublico.cl>), Índia (Government eMarketplace, em: $<$ https://gem.gov.in>) e Reino Unido (Crown Commercial Service eMarketplace, em: <https://www.crowncommercial.gov.uk/help-and-support/emarketplace/>). As experiências e limitações dos dois primeiros exemplos já foram discutidas nas seções 2 e 3, respectivamente. A entrada de cada fornecedor no catálogo de cada produto ou categoria é precedida do primeiro estágio do acordo-marco ou SRP, e sua saída decorre da expiração da ata ou de seu descredenciamento por insuficiência de desempenho, ou ainda por mútuo acordo ou mesmo falência da empresa. 
O uso das plataformas eletrônicas pode agilizar as compras de pequenos órgãos públicos de todas as esferas e ainda ser estendido a entidades filantrópicas a serviço do Estado. Essa agilidade pode ser estendida também aos pagamentos. A MP no 961/2020 introduziu os pagamentos antecipados nas compras feitas para o enfrentamento à Covid-19, buscando incentivar a participação dos fornecedores nas aquisiçóes públicas, considerando o cenário concorrencial

A caracterização desse cenário ganhou destaque na mídia brasileira, com relatos sobre as dificuldades nas aquisiçóes públicas de equipamentos de suporte à vida, como respiradores pulmonares, essenciais no combate à crise de saúde pública. ${ }^{37}$ Nesse contexto, um dos mecanismos para atrair potenciais fornecedores é o pagamento antecipado de despesas, respaldado pelo arcabouço normativo nacional em situaçóes excepcionais, conforme instrução da Orientação Normativa AGU no 37/2011 (Brasil, 2011b). ${ }^{38}$

As principais recomendações dessa orientação jurídica foram positivadas na legislação pátria, ainda que sob dependência de posterior validação pelo Poder Legislativo, por intermédio da MP no 961 . É o caso de ser o pagamento antecipado uma condição necessária ao sucesso da compra ou promova economia significativa de recursos; haver previsão dessa dinâmica nos instrumentos balizadores da contratação, permitindo a ciência dessa opção pelos potenciais fornecedores; e terem sido adotadas garantias para manter o resguardo do erário público caso haja uma inexecução contratual, somadas ao compromisso de restituição de eventuais recursos pagos de forma adiantada.

Dessa forma, esse mecanismo de incentivo ao mercado fornecedor teve seu uso fortalecido, tendo impulsionado reflexóes sobre a necessidade de alterar o mindset do

37. Ver como exemplo: <https://g1.globo.com/bemestar/coronavirus/noticia/2020/04/02/33percent-das-cidades-brasileiras-tem-no-maximo-10-respiradores-mecanicos-entenda-por-que-aparelho-e-essencial-no-combate-ao-coronavirus.ghtml>. 38. A redação original da Lei no $8.666 / 1993$, tal qual aprovada pelo Congresso Nacional, previa expressamente a possibilidade de pagamento antecipado em seu art. $55 \S 1$ :

Art. 55, $\$ 1 \div$. Os contratos de obras, de fornecimento para entrega futura de bens ou de serviços, especialmente os de serviços técnicos especializados que utilizem mão-de-obra intensiva, poderão prever adiantamentos de pagamentos, desde que não superiores ao valor da etapa em que se subdividir a sua execução, e desde que seja prestada garantia numa das modalidades previstas no art. 56 desta Lei, sem o limite estabelecido no $\$ 2^{\circ}$ daquele artigo.

Ocorre que o dispositivo foi vetado pelo presidente da República, persistindo na legislação brasileira vedações a tal prática, como a da Lei no 4.320/1964 (art. 62) ou ainda da própria Lei no 8.666/1993 (art. 65, II, "c"). No entanto, em âmbito federal, um decreto de 1986 contempla tal permissivo em caráter excepcional, o que embasa o posicionamento tanto da AGU quanto do TCU sobre o tema:

Decreto nำ93.872, de 1986: art. 38. Não será permitido o pagamento antecipado de fornecimento de materiais, execução de obra, ou prestação de serviço, inclusive de utilidade pública, admitindo-se, todavia, mediante as indispensáveis cautelas ou garantias, o pagamento de parcela contratual na vigência do respectivo contrato, convênio, acordo ou ajuste, segundo a forma de pagamento nele estabelecida, prevista no edital de licitação ou nos instrumentos formais de adjudicação direta. 
comprador público brasileiro (Fortini e Picinin, 2020; Pedra, Oliveira; e Torres, 2020), de forma a propiciar um olhar mais empático em relação aos desestímulos enfrentados pelo mercado ao firmar parcerias com o governo, como pagamentos realizados com prazos muito elásticos.

Apesar de ser uma prática com potencial para atrair fornecedores, subjazem à previsão da antecipação do pagamento as preocupaçôes com: $i$ ) a finalização rápida da compra para garantir a entrega; e ii) a liquidez das empresas. Quanto à primeira preocupação, a antecipação de pagamento não parece ser suficiente, pois mesmo as garantias previstas na $\mathrm{MP}$ no 961 não parecem ter impedido o inadimplemento contratual dos fornecedores - num tempo de pandemia, mais importante que reaver as garantias prestadas, quando isso acontece - é obter a entrega de um insumo escasso e urgente.

Quanto à segunda preocupação, entendemos que uma melhor solução seria ampliar o uso dos cartôes de pagamento. Essa solução poderia, inclusive, ser mantida após a pandemia em um reordenamento mais amplo do arcabouço institucional de compras públicas; diferentemente do que foi estatuído provisoriamente pela MP no 961, que, no longo prazo, seria um procedimento de alto risco para o gestor público.

De fato, é prática comum nas compras em marketplaces que os administradores da plataforma medeiem o processo de pagamento, pois consolidam as informaçóes cadastrais e do histórico de pagamento dos compradores, de um lado, e do histórico de desempenho dos vendedores participantes da plataforma. Essa mediação permite à plataforma agilizar o matching entre a entrega do produto ou serviço e o seu pagamento. Como dissemos anteriormente, nas compras governamentais, o órgão pode levar trinta dias para pagar o empenho liquidado. Isso para um fornecedor com problemas de liquidez pode ser mortal, pois não existe nem nunca existiu no Brasil um mercado desenvolvido de recebíveis oriundos do setor público na forma de notas de empenhos, mas uma administradora de cartão de crédito poderia tranquilamente fazer operaçóes de crédito lastreada em recebíveis assim que o marketplace governamental confirmasse junto ao órgáo a entrega do produto adquirido e liberasse junto à administradora do cartão o pagamento do fornecedor. ${ }^{39}$

Ou seja, os meios eletrônicos de pagamento são uma prática comum nas plataformas eletrônicas, em especial nas relaçóes privadas, enquanto um mecanismo que viabiliza

39. A taxa de juros, por sua vez, poderia ser parte do critério de adjudicação do contrato entre o marketplace e a administradora de cartão de crédito. 0 lance dos candidatos a administradores de cartão de crédito do marketplace poderia ser, por exemplo, o valor de uma taxa de desconto em relação a uma taxa de mercado, como a Selic ou a CDI. 
celeridade às transaçôes, controle e segurança às operações, e tal realidade não pode se fazer estranha à administração pública, que deve buscar constantemente, dado o contexto de limitação fiscal e obrigação de ofertar serviços públicos de qualidade, alternativas de adquirir e contratar bens e serviços em condiçôes cada vez mais próximas às do âmbito privado, seja em preço e em tempestividade de disponibilização, garantindo o cumprimento dos princípios constitucionais e legais de promover o máximo de competitividade entre os potenciais fornecedores, estimular práticas inovadoras, desenvolver mercados regionais e fomentar pequenas empresas.

Em verdade, já há instrumento no âmbito federal que promove essa aproximação público-privado na forma de pagamento, porém ele ainda é timidamente explorado: o Cartão de Pagamento do Governo Federal (CPGF), regulamentado atualmente pelo Decreto no $5.355 / 2005$. A sua utilizaçáo é prevista para pagamento de pequenas despesas, conhecidas como suprimento de fundos (para fazer frente a contrataçóes/aquisiçóes esporádicas e imprevisíveis, sujeitas a um rigoroso processo de prestaçáo de contas e transparência dos gastos) e pode ter sua utilização estendida para outras despesas. Isso já aconteceu com a compra direta de passagens aéreas, modelo de êxito, premiado e reconhecido pelos órgãos de controle (interno e externo), operado entre 2014 e 2018 no Poder Executivo do governo federal. Os procedimentos de compra de passagens aéreas nacionais pelo governo federal eram similares aos utilizados por qualquer cidadáo na aquisição de passagens aéreas; ou seja, diretamente das companhias aéreas transportadoras e por meio da comunicação via web. Além da economicidade (do valor dos bilhetes e da redução de rotinas de trabalho), a compra direta também trouxe transparência para os gastos, pois as pesquisas, escolhas e compras de viagens eram todas realizadas por meio eletrônico, inclusive o pagamento, e ficam armazenadas para posterior consulta, auditoria e verificação.

E essa foi só uma experiência que se materializou, sendo possível adotar o cartão de pagamento como instrumento de pagamento eletrônico para outros bens e serviços, propiciando à administração pública mais agilidade, transparência, controle e modernidade na gestão de recursos financeiros, facilitando o dia a dia da máquina administrativa nas rotinas de compras e pagamentos. Dentre os benefícios agregados pelo uso desse meio eletrônico de pagamento, percebidos no caso concreto da compra direta de passagens e facilmente extrapolados para outros contextos, destacam-se os seguintes.

1) Maior controle financeiro, com simplificação do processo de compra e pagamento, uma vez que cada portador possui limite de utilizaçáo autorizado pelo ordenador de despesa da unidade gestora e os dados do cartão podem ser inseridos em sistemas, observando políticas de segurança dos dados, tanto no armazenamento quanto na transmissão. 
2) Mais transparência, controle, automatização e otimização do uso da força de trabalho da administração.

3) Agilidade, pois sua utilização como meio garantidor do pagamento possibilita que a operação de compra seja realizada instantaneamente.

4) Fomento à atividade empresarial, inclusive das micro e pequenas empresas, em razão da atratividade do fornecimento de bens e serviços à administração pública federal incrementada pela facilidade e baixo custo operacional nos procedimentos de faturamento e a tempestividade e assertividade do recebimento do pagamento devido pelo fornecimento de bens e serviços.

5) Aumento do universo de interessados nos certames licitatórios para os casos em que esteja previsto o pagamento por meio de cartão eletrônico, por sua atratividade.

6) Ganho em economicidade, proporcionado pelo incremento na competitividade nos certames licitatórios.

Para alcançar tais benefícios, foi (e continua sendo) necessário realizar alteração normativa, uma vez que os órgáos e as entidades públicos estáo obrigados, nos pagamentos de seus fornecedores, a realizar a retenção na fonte de tributos como imposto sobre a renda, contribuição social sobre o lucro líquido, Contribuição para Seguridade Social (Cofins) e contribuição para o PIS/Pasep (art. 64 da Lei no 9.430, de 1996).

A rotina de retenção tributária na fonte para aquisições com uso de cartão como meio de pagamento, especialmente as realizadas de forma eletrônica pela web, é prática atualmente inexistente e se revela medida complexa e inviável de ser implementada no curto e médio prazo, pois exigiria significativas alteraçóes nos sistemas das instituiçóes envolvidas, bem como mudanças nos sistemas e processos contábeis e de vendas dos fornecedores. Uma alteração legal quanto a isso apenas estabeleceria que a obrigação de pagar os tributos incidentes sobre os pagamentos realizados pelo setor público com o cartão de pagamentos do governo federal se mantivesse integral, direta e exclusivamente sob a responsabilidade dos fornecedores de bens e serviços (contribuintes) contratado, não sendo caracterizada renúncia ou isenção fiscal.

Portanto entendemos que o uso ampliado do CPGF e outros cartóes de pagamentos de governos subnacionais, sem retenção tributária, poderia ser uma alternativa melhor para resolver falhas de mercado do que a antecipação pura e simples presente na MP no 961. 
É fato que a implantação da sistemática dos acordos-quadro via SRP ou acordo-marco pode requerer o uso adaptado do Siasg/ComprasNet, enquanto as rotinas de seleção de fornecedores, de emissáo de notas de empenho e de pagamento ocorrerem no sistema governamental. Caso a hipótese de contratação e pagamento via CPGF fosse validada, o cenário seria simplificado, demandando o uso do Siasg/ComprasNet somente caso a seleção do fornecedor ainda ocorresse pelo sistema oficial de compras do governo federal.

É possível expor, no quadro 4, a interação entre ferramentas e essas etapas da contratação, de acordo com diversos cenários de maturidade da sistemática.

No cenário 1, há, inicialmente, uma adaptação do Siasg/ComprasNet para realizar o primeiro estágio de seleção dos fornecedores, com uso de ferramentas básicas para conduzir o segundo estágio, como correio eletrônico e o portal da instituição na internet. No caso da estratégia 3, esse uso do Siasg/ComprasNet para o primeiro estágio pode ser substituído por um chamamento público de propostas fechadas, conduzido como uma espécie de licitação nos moldes do regulamento de licitaçóes e contratos da empresa estatal (subseção 5.1).

De qualquer modo, o cenário 1 introduz um modelo da rápida implantação, mas com carga operacional maior para manter o funcionamento da sistemática e a transparência das contratações efetivadas.

A formalização dos acordos-marco ocorreria pela assinatura de uma ata, espécie de pré-contrato centralizado, estimativo, contendo as regras para participação do segundo estágio. Esses contratos seriam decorrentes de pregáo eletrônico ou de RDC, se utilizado o Siasg/ComprasNet para promover a disputa do primeiro estágio, ou de uma simulação de compra direta, no caso do chamamento público.

Em qualquer desses casos, a efetivação das contrataçóes seria viabilizada pela emissão de notas de empenho com os fornecedores vencedores dos segundos estágios, por intermédio de execução descentralizada dos contratos no Siasg. Os pagamentos seguiriam a rotina atualmente vigente para organizaçóes públicas que utilizam esse sistema governamental.

Tecemos mais algumas consideraçôes sobre o uso da dispensa neste cenário na subseção 5.1 . 
O cenário 2 é uma evolução que agrega uma ferramenta de marketplace contendo os produtos credenciados e os fornecedores pré-contratados e dispondo dos preços máximos obtidos no primeiro estágio e outras condiçôes contratuais com uma performance mínima, que servem de limitadores para as ofertas a serem submetidas no segundo estágio. A transparência dos atos se tornaria mais automatizada, por componente de socialização dos dados na internet, diretamente.

Por fim, o cenário 3 traz à tona outra dinâmica, mais próxima dos marketplaces encontrados nas experiências internacionais. Ao incluir as etapas de contratação e de pagamento diretamente na ferramenta, mediante autorizaçáo para uso do CPGF com essa finalidade, torna-se possível agregar também o momento de primeiro estágio de seleçáo dos fornecedores, diante da independência em relaçáo ao Siasg/ComprasNet. Nesse cenário, os compradores utilizariam somente o mercado eletrônico para efetivar as contrataçóes via acordo-marco, otimizando os procedimentos e racionalizando esforços, mantendo os requisitos de transparência das açóes conduzidas. A sua utilização não impede, porém, que as estatais e as administraçóes direta e indireta continuem executando outros tipos de compras, mas náo existiria mais a concorrência por atas, pois um ou mais marketplace se especializaria, no máximo, por mercado coberto ou por esfera administrativa; num mundo ideal, todos os marketplaces existentes deveriam ter uma coordenação comum para tornar mais eficazes os mecanismos de agregação de compras.

Essa integração e alinhamento entre poucos portais reduziria também os custos de buscas dos fornecedores, que, hoje em dia, têm que recorrer a empresas especializadas em coletar avisos de licitação para informarem-se de todas as oportunidades de vendas à administração pública nas várias esferas de governo Brasil adentro. Um portal integrado reduziria as barreiras à entrada, fomentando assim a participação das empresas menores e ou sem experiência em vendas ao setor público. ${ }^{40}$

40. Vale citar um dos relatórios mencionado no box 1, sobre as compras públicas na Colômbia, em particular o CPAR de 2005 do Banco Mundial e do BID, que recomendava ao governo colombiano: "Fortalecer o Portal Único de Contratações, logrando a adesão e publicação de informação da totalidade de entidades públicas" e "tendente a uma unificação com o Sistema de Informação da Contratação Estatal". 0 relatório acentuava também que "a iniciativa do Portal Único de Contratação é um primeiro passo que merece ser potencializado, exigindo para as entidades a emissão de informações e definindo o PUC como único ponto de acesso à informação de compras públicas da Colômbia" (Banco Mundial e BID, 2005, p. 14, 15 e 39). 


\section{QUADRO 4}

Ferramentas informatizadas destinadas à operacionalização das estratégias 1 a 3, por etapa da contratação e por cenário de maturidade da sistemática

\begin{tabular}{|c|c|c|c|}
\hline Etapa & $\begin{array}{l}\text { Cenário } 1 \\
\text { ComprasNet }\end{array}$ & $\begin{array}{l}\text { Cenário } 2 \\
\text { Marketplace + ComprasNet }\end{array}$ & $\begin{array}{l}\text { Cenário } 3 \\
\text { Marketplace + Cartão de Pagamentos } \\
\text { do Governo Federal }\end{array}$ \\
\hline $\begin{array}{l}\text { Seleção dos } \\
\text { fornecedores } \\
\text { (primeiro } \\
\text { estágio) }\end{array}$ & $\begin{array}{l}\text { Simulação de pregão eletrônico ou de } \\
\text { RDC }{ }^{1} \text { para ranquear os fornecedores } \\
\text { ou realização de chamamento } \\
\text { público de propostas fechadas } \\
\text { (dispensa eletrônica?). Formalização } \\
\text { de acordos-marco no Siasg, com } \\
\text { natureza pré-contratual, para permitir } \\
\text { a emissão de notas de empenho a } \\
\text { cada efetivação de contratação. }\end{array}$ & $\begin{array}{l}\text { Simulação de pregão eletrônico } \\
\text { ou de RDC para ranquear os } \\
\text { fornecedores ou realização de } \\
\text { chamamento público de propostas } \\
\text { fechadas (dispensa eletrônica?). } \\
\text { Formalização de acordos-marco no } \\
\text { Siasg, com natureza pré-contratual, } \\
\text { para permitir a emissão de notas } \\
\text { de empenho a cada efetivação de } \\
\text { contratação. }\end{array}$ & $\begin{array}{l}\text { Procedimento simplificado do tipo } \\
\text { envelopes fechados para credenciar } \\
\text { os fornecedores, registrando seus } \\
\text { scores - que serão utilizados no } \\
\text { segundo estágio. } 0 \text { critério de } \\
\text { julgamento pode ser menor preço, } \\
\text { maior desconto ou técnica e preço. }\end{array}$ \\
\hline $\begin{array}{l}\text { Seleção dos } \\
\text { fornecedores } \\
\text { (segundo } \\
\text { estágio) }\end{array}$ & $\begin{array}{l}\text { Convite e envio de propostas por } \\
\text { mensagem eletrônica, transparência } \\
\text { pelo portal da organização } \\
\text { contratante. }\end{array}$ & $\begin{array}{l}\text { Convite, envio de propostas e } \\
\text { transparência pelo marketplace. }\end{array}$ & $\begin{array}{l}\text { Coleta de propostas, que serão } \\
\text { avaliadas levando-se em conta no } \\
\text { score final, como parte da fórmula, } \\
\text { o ranqueamento original do } \\
\text { primeiro estágio. }\end{array}$ \\
\hline Contratação & $\begin{array}{l}\text { Emissão de nota de empenho via } \\
\text { Siasg. }\end{array}$ & $\begin{array}{l}\text { Emissão de nota de empenho via } \\
\text { Siasg. }\end{array}$ & $\begin{array}{l}\text { Via marketplace, com adaptação de } \\
\text { um meio de pagamento por cartão } \\
\text { de crédito, para uso do CPGF. }\end{array}$ \\
\hline Pagamento & Via Siasg. & Via Siasg. & $\begin{array}{l}\text { Pré-autorizado no momento da } \\
\text { contratação. Efetivado contra } \\
\text { confirmação de entrega. }\end{array}$ \\
\hline
\end{tabular}

Elaboração dos autores.

Nota: ${ }^{A} \mathrm{~A}$ modalidade concorrência padece do problema que a fase de habilitação precede a abertura das propostas, o que propicia comportamentos defensivos de impugnação generalizada de concorrentes antes mesmo de se saber da competitividade de suas propostas, daí não ser uma modalidade indicada para essa fase ou qualquer outra. A maior prova da desvantagem dessa modalidade é o predomínio avassalador da modalidade pregão nas licitações com registro de preços.

Note-se que todos e cada um dos cenários podem ser implementados por qualquer uma das estratégias 1 a 3 - a diferença estaria no teor da regulamentação exarada em cada uma delas. Em outras palavras, cada estratégia envolve uma abordagem legislativa-regulatória diferente. Além disso, a etapa 3 pode correr em paralelo à estratégia 1 ou à estratégia 2, pelo seu caráter experimental. $\mathrm{O}$ cenário 1 é o mais simples e o 2 pode ser visto como uma evolução do primeiro. O cenário 3 é o mais sofisticado de todos.

Em suma, há espaço para adotar de forma imediata acordos-quadro, seja com o rótulo de SRP, seja com o rótulo de acordo-marco, como instrumento de centralização de compras, inaugurando seu uso no cenário brasileiro de compras públicas, inicialmente para otimizar as contrataçôes em prol do enfrentamento da emergência da Covid-19, mas certamente se solidificando como sistemática atualizada de aquisiçóes governamentais, contribuindo para catalisar a implementação de políticas públicas. 
A maior flexibilidade dos acordos-marco geridos por empresas estatais permite, também, o emprego de ferramentas de marketplace de forma mais imediata e alinhada com as formas flexíveis de contratação.

\subsection{Usando a dispensa nos cenários 1 e 2}

Como abordado, são bastante claros os objetivos das inovaçóes trazidas pela legislação de enfrentamento à Covid-19. A exposição de motivos da referida MP n⿳0-926/2020 deixa-os explícitos: desburocratizar procedimentos, simplificar e agilizar os processos de contratação, especialmente por dispensa. Para enfrentamento da crise, o importante é ser efetivo, sem formalismo que possa dificultar a obtenção dos suprimentos necessários. Entretanto, essa disposição excepcional, com todas suas implicaçôes, exige mais que o permissivo legal. Exige inovação prática. Nas palavras da Advocacia-Geral da União (AGU), "de nada adianta a criação de novos sistemas se a sua operacionalização parte de instrumentos antigos"; 41 e "diante do cenário de combate à Covid-19, é necessário que velhas rotinas sejam revistas. "’2

Desse modo, se é para abandonar velhas rotinas e instrumentos antigos em nome da eficiência, uma boa alternativa pode ser inovar a seleção de ofertas para contratação direta, por dispensa de licitação. Primeiro, é preciso reforçar que a dispensa da Covid-19 não se confunde com a antiga dispensa do art. 24 da Lei no 8.666/1993.

Ainda que haja eventualmente similaridades, as hipóteses de dispensa são material e faticamente distintas, devendo ser tratadas de forma independente. Não há que se falar em arrastamento dos entendimentos doutrinários e jurisprudenciais relativos ao artigo 24, IV, da Lei ㄲo 8.666/1993 para as contrataçóes destinadas ao atendimento da presente situação de emergência em saúde pública, tendo sempre em consideração esse caráter singular da contratação direta disciplinada pela Lei no $13.979 / 2020 .{ }^{43}$

Sendo, portanto, uma hipótese excepcional específica, que permite contratar diretamente, em função da relação do objeto com o enfrentamento da pandemia, pode-se selecionar, em primeira etapa ou estágio, todos os fornecedores que cumpram os requisitos mínimos e aceitem praticar limite de preço, definido previamente pelo contratante.

Dinamicamente, os fornecedores podem ofertar quantidades e preços conforme sua capacidade e interesse comercial, limitados ao preço-teto previamente definido.

41. Parecer no 00002/2020/CNMLC/CGU/AGU, de 26 de março de 2020.

42. Parecer no 00254/2020/CONJUR-MS/CGU/AGU, de 10 de abril de 2020.

43. Parecer $n^{\circ} 00002 / 2020 /$ CNMLC/CGU/AGU, de 26 de março de 2020.

62 
A cada demanda efetiva, pode-se pensar em duas modalidades de escolha, a exemplo do que ocorre nos acordos-quadro do Chile: $i$ ) pequenas compras: em que a seleção ocorre diretamente, com base nos preços dinâmicos de cada fornecedor e as quantidades disponíveis; ii) grandes compras: em que se abre um segundo estágio, com disputa rápida, processada eletronicamente, com base no preço e nas quantidades que cada fornecedor interessado oferece.

Veja-se que a contratação continua se baseando nas mesmas premissas da dispensa: justificativa fundamentada da escolha do fornecedor e justificativa do preço.

A escolha do fornecedor se baseia em dois estágios: primeiro, a pré-qualificação de todos que se interessem em atender às necessidades nas condiçóes definidas pelo contratante; segundo, no momento da demanda, escolhe-se o fornecedor com a melhor proposta no momento, o que já garante, também, a justificativa do preço.

Nas pequenas compras, o preço é o mais bem posicionado dinamicamente, com base nas ofertas que os próprios fornecedores cadastram a qualquer momento, nunca ultrapassando o limite previamente definido, obviamente balizado por pesquisa apropriada. Nas grandes compras, o preço é colocado em disputa, cujo único processamento se refere ao preço e às quantidades que cada fornecedor se dispóe a ofertar para aquela demanda específica.

Assim, não só é perfeitamente viável, juridicamente, mas também desejável, pelas vantagens que representa, operar as dispensas por meio de plataformas eletrônicas, preferencialmente do tipo marketplace, emulando registros de preços em dois estágios, com pagamento por cartão, mediante cumprimento da entrega pretendida.

\subsection{0 caso da Ebserh}

Como dito antes, a estratégia de contratação pública coordenada por empresas estatais pode ter como piloto a Ebserh, com experiência em compras conjuntas para os hospitais universitários federais (HUFs) geridos por essa empresa estatal.

A Ebserh foi criada pela Lei no 12.550, de 15 de dezembro de 2011 (Brasil, 2011a), como empresa pública dependente do Tesouro Nacional, vinculada ao Ministério da Educação (MEC). Possui como missão prestar serviços de assistência à saúde e apoiar o ensino e a pesquisa no campo da saúde pública, atuando na gestáo de, atualmente, quarenta HUFs pertencentes a instituiçôes federais de ensino superior (Ifes) que 
firmaram contrato de gestão com a estatal. A centralização das compras faz parte da trajetória da Ebserh e de seu modelo de gestão, construído para solucionar os desafios de aprimoramento e de reestruturação dos HUFs (Santos, 2019), cujos resultados têm sido considerados positivos, como redução do subfinanciamento crônico, ampliação real dos recursos destinados às unidades hospitalares, redução da mão de obra com vínculos precários, ampliação do número de colaboradores, profissionalização da gestão e aumento no número de leitos (Pereira Júnior, 2018).

A característica da Ebserh como campo de prática do ensino e da pesquisa implica, em um contexto de emergência de saúde pública, oportunidade de uso das estruturas hospitalares para desenvolver soluçóes para o enfrentamento da crise. Assim, a manutenção do funcionamento desses HUFs não visa somente a promoção de assistência à saúde no âmbito do SUS, mas também a disponibilização de meios para os pesquisadores se engajarem, por exemplo, na descoberta e na criação de rotinas e protocolos para prevenção e tratamento da Covid-19. ${ }^{44}$

Desse modo, o uso do acordo-marco como forma inovadora de viabilizar contrataçóes públicas centralizadas na Ebserh emerge como oportunidade de explorar a estatal como laboratório de inovação. Como forma de implementar o procedimento de compra em dois estágios, é necessário alterar o regulamento interno de compras da empresa.

Atualmente, as compras realizadas pela estatal são regidas pelo Regulamento de Licitaçóes e Contratos da Ebserh (RLCE), revisado em 24 de setembro de 2019 (Brasil, 2019). Há duas alternativas para incorporar os dispositivos dos acordos-quadro na empresa: uma alteração do RLCE para inclusão dos trechos referentes à nova sistemática, ou, considerando o caráter inicialmente temporário da solução posta, a aprovação de um anexo ao RLCE para tratar exclusivamente do tema.

A ideia do texto anexo, intitulado RLCE - dispositivos de enfrentamento da emergência da Covid-19, possibilita uso da sistemática dos acordos-marco em uma espécie de protótipo, com o registro de um prazo de vigência desses dispositivos, atrelado ao cenário nacional da crise da Covid-19. Nesse formato, o encerramento das açóes de enfrentamento da emergência pode ser seguido de uma incorporaçáo definitiva dos acordos-marco no RLCE, em um segundo momento, com espaço para aprimoramento dos dispositivos utilizados durante o teste da sistemática.

44. Ver exemplo em: <https://www.gov.br/ebserh/pt-br/comunicacao/noticias/rede-ebserh-participa-de-estudos-nacionais-e-internacionais-sobre-o-novo-coronavirus-1>. 
Por sua vez, uma solução definitiva também pode ser empreendida: a própria revisão do RLCE e inclusão dos dispositivos referentes à nova forma de aquisiçóes centralizadas, aproveitando-se o mesmo texto anexo. A ideia, nesse caso, é promover a assimilação da nova sistemática não com o escopo exclusivo do enfrentamento da crise da Covid-19, mas de forma definitiva. O modelo de prototipagem se mantém, dado o uso imediato como forma de buscar a manutenção do funcionamento das unidades hospitalares durante a emergência, mas aproveitar-se-ia a oportunidade para enraizar a nova dinâmica no arcabouço normativo da estatal. No caso da necessidade de aprimoramento pós-crise, com base nos ensinamentos do protótipo, seria possível pleitear nova atualizaçáo do RLCE, mantendo um ciclo de revisóes periódicas do regulamento.

De qualquer modo, verifica-se como possível o uso imediato dos acordos-marco como instrumento de centralização das compras na Ebserh, cabendo à estatal a promoção dos ritos de aprovação de uma atualizaçáo sobre o seu regulamento interno de compras. A partir disso, a operacionalizaçáo dos acordos-marco passa a ser o desafio, tendo em vista que os sistemas de compras governamentais disponíveis no país não estão adaptados a essa sistemática.

Assim, a dinâmica dos acordos-marco, principalmente a natureza de dois estágios, demanda a elaboração de ferramenta própria para sua operacionalizaçáo, especialmente com a possibilidade de sua expansão para um modelo de mercado eletrônico de compras/ marketplace. Para tanto, seria necessário conduzir um desenvolvimento próprio de sistema de informação ou buscar a adaptação de alguma ferramenta disponível no mercado.

Considerando a oportunidade de imprimir celeridade no uso dos acordos-marco, recomenda-se a realização de parceria com o mercado para captar uma ferramenta similar e buscar o seu desenvolvimento. Um chamamento público em busca de soluções, ou ainda um diálogo competitivo amplo nos moldes do RLCE, adaptado de rotinas concorrenciais internacionais, aparenta ser a solução mais célere para pactuar um desenvolvimento direto da ferramenta.

O ponto relevante é definir qual o escopo da ferramenta de marketplace a ser desenvolvida pelo mercado, conforme identificação de quais etapas do procedimento de contratação seriam retiradas do Siasg/ComprasNet e repassadas ao novo sistema. 


\section{CONSIDERAÇÕES FINAIS}

O Brasil e o mundo têm experimentado uma realidade dramática na obtenção de insumos básicos de saúde diante do cenário de ruptura das cadeias internacionais de suprimentos, causada pelo enfrentamento coletivo e descoordenado da emergência de saúde pública do coronavírus. O estado de calamidade pública instituído no país em fevereiro de 2020 propiciou o rápido surgimento de um direito provisório com vistas a suprir mais rápida e eficazmente as urgentes necessidades de aquisiçóes e contrataçóes.

Entre as medidas recentemente positivadas, destacamos a previsão de utilização da dispensa de licitação para seleçáo de fornecedores para atas de registro de preços, a ampliação do uso do Regime Diferenciado de Contrataçóes, o pagamento antecipado de despesas contratadas, e o aumento temporário do limite de valor de dispensa de licitação. Destaca-se que boa parte das dinâmicas inovadoras explicitadas na legislação provisória tem dispositivos análogos no PL no 1.292/1995, em tramitaçáo no Congresso Nacional como possível substituto do arcabouço legal geral de compras públicas no Brasil, a Lei no ${ }^{8} .666 / 1993$. Se por um lado tais inovaçóes apontam para um cenário experimentalista promissor (Justen Filho, 2020), a criação de novos regimes paralelos de contratação pode ser vista como um bypass institucional (Toledo, 2020), que acentua a falta de sistematicidade da legislação sobre compras públicas no país, já há muito caracterizado como uma "colcha de retalhos" (Oliveira, 2015).

Ademais, os avanços propiciados pelas novas medidas ofertadas aos gestores públicos podem não ser ainda suficientes para permitir uma pronta e adequada resposta no âmbito do funcionamento logístico das unidades de saúde. Como exemplo, a maior facilidade em realizar registros de preços potencializaria o uso das compras coordenadas de vários entes, mas subsistem os desafios desse modo de contratação de um único fornecedor, reduzindo as chances de garantir o abastecimento dos estoques, aumentando o risco de insucesso de um procedimento que representa custos (seja de tempo, seja de pessoal) para a administração e reduz seu espaço de resposta para eventuais contingências. Além disso, o SRP não assimila adequadamente flutuaçóes de preços, comuns durante a pandemia, por trazer valor e fornecedor fixos, definidos na etapa única de seleção.

Aparenta ser necessário estruturar uma sistemática inovadora para as contrataçôes públicas, como a adoção dos acordos-quadro multifornecedores, permitindo uma parceria com uma pluralidade de players do mercado, tornando maiores as chances de garantia de ressuprimento das estruturas assistenciais. A própria flutuação de preços se torna melhor assimilada por sua dinâmica de dois estágios, impedindo mergulhos de 
propostas em uma rodada única de disputa, gerando parcerias com riscos de inexecução por preços insustentáveis.

Em outro exemplo, os pagamentos antecipados de despesas contratadas aproximam o comprador público do comprador privado em possibilidade de transferência de recursos, mas requerem providências bastante cautelosas para se evitar prejuízo ao erário na contratação de empresas de reputação duvidosa, além de não solucionar a assimetria entre as duas esferas, visto que a retenção tributária obrigatória pelo poder público se apresentada como custo adicional aos fornecedores, que recebem essa verba nas vendas privadas e quitam suas obrigaçóes por seu planejamento tributário.

Por seu turno, a adoção do cartáo de pagamentos, sem retenção tributária, de fato traria incentivos à participação do mercado nas compras governamentais, reduzindo os riscos de liquidaçáo e pagamento das obrigaçóes estatais, além de promover transparência aos gastos e evitar corrupçóes no estágio de pagamento da despesa pública.

Entendemos que a coordenação das aquisições seria mais eficaz na presença de um comando centralizado e harmônico entre os membros do Pacto do SUS, que gerisse as intenções de registro de preço e estendesse o almoxarifado virtual federal em direção a um marketplace para as três esferas administrativas e, possivelmente, envolvendo também entidades a serviço do SUS. Isso permitiria:

1) Fazer grandes compras onde houvesse vantagem na distribuição centralizada inclusive possibilitando a formação de estoques estratégicos, como foi feito pela Comissão Europeia ${ }^{45}$ mas também

2) Fazer grandes acordos-marco, pelos quais uma unidade central credenciaria os fornecedores a fornecer com base num primeiro certame classificatório e eliminatório, seguindo critérios de preços, garantia, prazo de entrega, frete etc.; e em seguida as unidades compradoras fariam seus minicertames (call-offs) requerendo ofertas dos fornecedores já inscritos, usando os scores da primeira rodada como ponto de partida para os scores desses call-offs.

De fato, a resenha internacional mostra benefícios em compras conjuntas e no uso de licitações eletrônicas, mas não existe uma fórmula única. No Chile, por exemplo, demonstrou-se que o marketplace local não obtinha preços táo baixos quanto a central de abastecimento, mas não se levou em conta o custo de toda a cadeia logística nem os

45. Ver: <https://ec.europa.eu/commission/presscorner/detail/en/ip_20_476>. 
custos de estocagem. No Brasil, as grandes compras atraem poucos fornecedores. Elas podem obter preços bem baixos, mas, dependendo da estrutura de oferta do produto, pode acabar concentrando demais o mercado e inviabilizando a sobrevivência e ou entrada dos pequenos fornecedores, que são os que exercem pressão competitiva ao longo do tempo. O que temos no Brasil são muitas compras pequenas e poucas compras grandes.

Além da concentração de mercado, a solução de grandes armazéns dá ao órgão coordenador das compras conjuntas um grande poder, mas também uma grande responsabilidade, pois tem de gerenciar a logística de distribuição dos itens aos vários entes, o que representa um enorme desafio num país de dimensóes continentais como o Brasil. Uma solução de marketplace - ou de qualquer tipo de acordo-marco - resguarda o poder do órgão responsável de gerenciar filas de acesso a entregas dos itens comprados, mas dá mais opçóes: por exemplo, ao executar sua ordem de compra, a unidade compradora poderia optar por providenciar sua própria logística em relação ao centro de distribuição do fornecedor, contratá-la diretamente do fornecedor ou ainda utilizar um contrato máster mantido pelo portal ou vinculado ao acordo-marco. Este contrato máster, por sua vez, pode ser subdividido em lotes de logística regionais e nacional, dando mais oportunidades a operadores logísticos menores.

A coordenação das compras permitiria ao Estado gerenciar e balancear melhor seus objetivos, tais como o desenvolvimento regional, o atendimento a emergências e a promoção de pequenos negócios, além de viabilizar a extração de ganhos de escala, com incorporação de novas tecnologias nas suas operaçóes e tendo ao seu dispor produtos mais atualizados do mercado. Todavia, apesar de haver instrumentos legais que definem competências dos atores nos diferentes níveis e esferas governamentais e que colocam à sua disposição instrumentos de colaboração e unificação de esforços, deve-se reconhecer a ausência de uma atuação coordenada e de um protagonista que se ocupe de orquestrar os envolvidos, lacuna cujo preenchimento, além de fundamental para a implementação seja das propostas apresentadas neste texto, seja de outras inciativas correlatas, vem sendo demandado pelos agentes públicos locais. ${ }^{46}$

Mas não podemos esquecer que, em vários casos, os maiores ganhos de escala são na redução da replicação de custos de transação incorridos na realização de certames licitatórios e adjudicação de contratos e atas de registro preço. $\mathrm{O}$ particionamento de compras em vários fornecedores pode ter o condão de gerar dinamismo econômico nas

46. Disponível em: <https://www.cnnbrasil.com.br/politica/2020/06/25/governadores-querem-ajuda-do-governo-federal-para-comprar-sedativos $>$. 
várias regiôes do Brasil, maior celeridade na entrega, e também já foi utilizado como ferramenta de promoção de pequenas e médias empresas em países da OCDE. Combiná-lo com meios de pagamento mais ágeis, como cartôes de pagamento para pequenas compras, injetaria mais rapidamente capital nas cambaleantes empresas de pequeno porte do Brasil. O uso de um portal único de compras federais e sua integração com portais subnacionais traria um benefício adicional de grande importância: a redução dos custos de busca dos fornecedores por oportunidades de venda: atualmente cada fornecedor precisa assinar um serviço de alertas privado para dar conta de todos os portais eletrônicos, diários oficiais e grandes veículos de imprensa onde são publicados os avisos de dispensa e de processos licitatórios, ou então buscar, ele mesmo, em cada uma dessas fontes.

A pandemia pode ser uma ótima oportunidade de acelerarmos a convergência para essas compras coordenadas. Empresas estatais, como a Ebserh, podem ser o embriáo de um esforço concertado de compras nos três níveis de governo, demonstrando o ganho em economia e eficiência nas contrataçóes públicas e, viabilizando condiçóes para, após demonstrados os resultados e tratadas as necessidades mais imediatas de ajustes a esse modelo experimental, a expansão do marketplace para outros objetos de contratação, que carecem da mesma celeridade, transparência e efetividade. E, ainda, faz consolidar um modelo em que a cooperação entre os entes confirma sua importância e alinhamento com as práticas internacionais, e já constantes no PL no $1.292 / 1995$, de formação de centrais de compras e consórcios públicos pelos estados e municípios, respectivamente, como meio de reduzir despesas, concentrar esforços, desenvolver núcleos especializados em contrataçóes e potencializar o uso do poder de compras governamental como política pública de desenvolvimento e transformação.

\section{REFERÊNCIAS}

ADESINA, A.; WIRTZ, V. J.; DRATLER, S. Reforming antiretroviral price negotiations and public procurement: the Mexican experience. Health policy and planning, v. 28, n. 1, p. 1-10, 2013.

ALBANO, G. Contratación de emergencia: Un "test de estrés" para los sistemas de compras públicas. Apresentação no Tercer Diálogo Regional de Política y Gestión Fiscal Virtual (DRP). Compras Públicas y Soluciones Digitales: Desafíos en la emergencia Covid-19. Washington (DC): Banco Interamericano de Desenvolvimento, 2020.

ALBANO, G.; NICHOLAS, C. The Law and Economics of Framework Agreements. Cambridge: Cambridge U.P., 2016. 
AMARAL, S. M. S. D.; BLATT, C. R. Municipal consortia for medicine procurement: impact on the stock-out and budget. Revista de saúde pública, n. 45, p. 799-801, 2011.

ARAUJO, T.; MONTENEGRO, L. Pandemia, emergência e compras públicas: experiências de Brasil e União Europeia. 2020. Disponível em: <https:/www.jota.info/opiniao-e-analise/artigos/ pandemia-emergencia-e-compras-publicas-experiencias-de-brasil-e-uniao-europeia-21052020>.

AZZOPARDI-MUSCAT, N.; SCHRODER-BÄCK, P.; BRAND, H. The European Union Joint Procurement Agreement for cross-border health threats: What is the potential for this new mechanism of health system collaboration? Health Economics, Policy and Law, v. 12, n. 1, p. 3-59, 2017.

BALDI, S.; VANNONI, D. The impact of centralization on pharmaceutical procurement prices: the role of institutional quality and corruption. Regional Studies, v. 51, n. 3, p. 426-438, 2017.

BANCO MUNDIAL; BID - BANCO INTERAMERICANO DE DESENVOLVIMENTO. Colombia: Informe del Diagnóstico de la Adquisiciones del País. 2005. (CPAR Update Report n. 33260).

BARBER, S. L. et al. The reform of the essential medicines system in China: a comprehensive approach to universal coverage. Journal of Global Health, v. 3, n. 1, 2013.

BARBOSA, K. O Sistema Brasileiro de Registro de Preços. In: SALGADO, L. H.; FIUZA, E. P. S. (Orgs.). Marcos regulatórios no Brasil: aperfeiçoando a qualidade regulatória. Rio de Janeiro: Ipea, 2015.

BARBOSA, K.; FIUZA, E. P. S. Demand aggregation and credit risk effects in pooled procurement: evidence from the Brazilian public purchases of pharmaceuticals and medical supplies. São Paulo: EESP/FGV, 2012. (Texto para Discussão, n. 299 - C-Micro 14).

BARTELS, D. Centralizing procurement of medicines to save costs for Denmark. Eurohealth Observer, v. 22, n. 2, 2016.

BERNHEIM, B. D.; WHINSTON, M. D. Menu auctions, resource allocation, and economic influence. The quarterly journal of economics, v. 101, n. 1, p. 1-31, 1986.

BERGMAN, M. A.; GRANLUND, D.; RUDHOLM, N. Squeezing the Last Drop Out of Your Suppliers: An Empirical Study of Market-Based Purchasing Policies for Generic Pharmaceuticals. Oxford Bulletin of Economics and Statistics, v. 79, n. 6, p. 969-996, 2017.

BONACCORSI, A. et al. Auctions vs. Bargaining: An Empirical Analysis of Medical Device Procurement. Laboratory of Economics and Management (LEM). Pisa, Italy: Sant'Anna School of Advanced Studies, 1999.

BOSIO, E. et al. Public Procurement in Law and Practice. National Bureau of Economic Research, 2020. 
BRASIL. Substitutivo da Câmara dos Deputados ao Projeto de Lei no 1.292-E de 1995 do Senado Federal (PLS no 163/95 na Casa de origem), que altera a Lei no 8.666, de 21 de junho de 1993, que regulamenta o art. 37, inciso XXI, da Constituiçáo Federal, institui normas para licitações e contratos da Administração Pública e dá outras providências. Brasília, 1995. Disponível em: <https://www.camara.leg.br/proposicoesWeb/fichadetramitacao?idProposicao=16526>. Acesso em: 12 abr. 2020.

. Lei no 12.550 , de 15 de dezembro de 2011. Autoriza o Poder Executivo a criar a empresa pública denominada Empresa Brasileira de Serviços Hospitalares. Brasília: Congresso Nacional, 2011a. Disponível em: <http:/www.planalto.gov.br/ccivil_03/_Ato2011-2014/2011/ Lei/L12550.htm> . Acesso em: 12 abr. 2020.

Advocacia-Geral da União. Orientação Normativa nº 37, de 13 de dezembro de 2011. Brasília: Advocacia-Geral da União, 2011b. Disponível em: <http://www.agu.gov.br/ orientacao $>$. Acesso em: 6 jun. 2020.

. Decreto no 7.892, de 23 de janeiro de 2013. Regulamenta o Sistema de Registro de Preços previsto no art. 15 da Lei no 8.666, de 21 de junho de 1993. Brasília, 2013. Disponível em: <http:/www.planalto.gov.br/ccivil_03/_Ato2011-2014/2013/Decreto/D7892.htm\#art29>. Acesso em: 12 abr. 2020.

Escola Nacional de Administração Pública. Açóes premiadas no 20 o Concurso Inovaçáo na Gestáo Pública Federal. Brasília: Escola Nacional de Administração Pública, 2015.

Lei no 13.303 , de 30 de junho de 2016. Dispóe sobre o estatuto jurídico da empresa pública, da sociedade de economia mista e de suas subsidiárias, no âmbito da União, dos Estados, do Distrito Federal e dos Municípios. Brasília: Congresso Nacional, 2016. Disponível em: <http://www.planalto.gov.br/ccivil_03/_ato2015-2018/2016/lei/113303.htm>. Acesso em: 12 abr. 2020.

Empresa Brasileira de Serviços Hospitalares (Ebserh). Regulamento de Licitações e Contratos da Ebserh (1ª revisão). Brasília: Ebserh, 2019. Disponível em: <http://ebserh.gov. br/sites/default/files/paginas/201909/Anexo1_Regulamento_de_Licitacoes_e_Contratos__REVISAO_1_FINAL..pdf >. Acesso em: 12 abr. 2020.

BUCCIOL, A.; CAMBONI, R.; VALBONESI, P. Buyers' ability and discretion in procurement: a structural analysis of Italian medical devices. 2019. Mimeo. Disponível em: <https:// extranet.sioe.org/uploads/sioe2019/bucciol_camboni_valbonesi.pdf>. Acesso em: 6 maio 2020 .

BURNETT, F. Reducing costs through regional pooled procurement. Essential Drugs Monitor, v. 32, p. 7-8, 2003.

BURR-ORTUZAR, G. et al. Challenges in Chilean E-Procurement System: A Critical Review in Digital Governance and E-Government Principles Applied to Public Procurement. IGI Global, 2017. 
CHIPTY, T.; SNYDER, C. M. The Role of Firm Size in Bilateral Bargaining: A Study of the Cable Television Industry. Review of Economics and Statistics, v. 81, n. 2, p. 326-340, 1999.

CHOKSHI, M. et al. A cross-sectional survey of the models in Bihar and Tamil Nadu, India for pooled procurement of medicines. WHO South-East Asia Journal of Public Health, v. 4, n. 1, p. 78-85, 2015.

COSTA, C. C. M.; TERRA, A. C. P. Compras públicas: para além da economicidade. Brasília: Enap, 2019. 135 p. Disponível em: <https://repositorio.enap.gov.br/handle/1/4277>. Acesso em: 11 abr. 2020.

CURTO, S. et al. Regional tenders on biosimilars in Italy: an empirical analysis of awarded prices. Health Policy, v. 116, n. 2-3, p. 182-187, 2014.

DANZON, P. M.; MULCAHY, A. W.; TOWSE, A. K. Pharmaceutical pricing in emerging markets: effects of income, competition, and procurement. Health economics, v. 24, n. 2, p. 238-252, 2015.

DECAROLIS, F. et al. Rules, Discretion, and Corruption in Procurement: Evidence from Italian Government Contracting. CEPR, 2020. (Discussion Paper, n. 14794).

DI PIETRO, M. S. Direito Administrativo. Rio de Janeiro: Forense, 2018.

DUBOIS, P.; LEFOUILI, Y.; STRAUB, S. Pooled Procurement of Drugs in Low and Middle Income Countries. Mimeo. 2019. Disponível em: <https:/www.cgdev.org/sites/default/files/ pooled-procurement-drugs-low-and-middle-income-countries.pdf>. Acesso em: 6 maio 2020.

EBRD - EUROPEAN BANK FOR RECONSTRUCTION AND DEVELOPMENT. Public Procurement: Is open competition good for small and medium-sized enterprises? 2017. Disponível em: <www.ebrd.com/documents/ogc/public-procurement-is-open-competition-good-for-smes.PDF>.

ESPÍN, J. et al. How can voluntary cross-border collaboration in public procurement improve access to health technologies in Europe. Copenhagen: WHO Regional Office for Europe, 2016. (Policy Brief, n. 21).

EWEN, M. et al. Comparative assessment of medicine procurement prices in the United Nations Relief and Works Agency for Palestine Refugees in the Near East (UNRWA). Journal of pharmaceutical policy and practice, v. 7, n. 1, p. 13, 2014.

FERNANDES, C. A centralização das compras na administração federal: liçôes da história. In: CONGRESSO CONSAD DE GESTÃO PÚBLICA, 8., Brasília, 2015.

FERRARIO, A.; HUMBERT, T.; KANAVOS, P.; PEDERSEN, H. B. Strategic procurement and international collaboration to improve access to medicines. Bulletin of the World Health Organization, v. 95, n. 10, p. 720, 2017. 
FIUZA, E. Desenho institucional em compras públicas. In: FIUZA, E.; SALGADO, L. H. (Org.). Marcos regulatórios no Brasil: aperfeiçoando a qualidade regulatória. Rio de Janeiro: Ipea, 2013.

FIUZA, E. P. S.; MEDEIROS, B. A. A agenda perdida das compras públicas: rumo a uma reforma abrangente da lei de licitaçóes e do arcabouço institucional. (Texto para Discussão, n. 1990). Rio de Janeiro: Ipea, 2014.

FIUZA, E. P. S.; POMPERMAYER, F. M.; RAUEN, A. T. A retomada da agenda perdida das compras públicas: notas sobre o novo projeto de lei de licitaçóes da Câmara dos Deputados em 2018-2019. Brasília: Ipea, 2019. (Nota Técnica, n. 46).

FIUZA, E. P. S.; RAUEN, A. T. Recomendaçóes de alteração no texto do substitutivo ao Projeto de Lei no 1.292/1995. Brasília: Ipea, 2019. (Nota Técnica, n. 49).

FIUZA, E. P. S. et al. Revisáo do arranjo das compras públicas a partir de um contexto de crise. Rio de Janeiro: Ipea, 2020. (Nota Técnica, n. 68).

FORTINI, C.; PICININ, J. Pagamento antecipado por bens adquiridos pelos órgáos públicos durante a pandemia: oportunidade de repensar aspectos da contratação pública. 2020 . Disponível em: <https://ronnycharles.com.br/pagamento-antecipado-por-bens-adquiridos-pelos-orgaos-publicos-na-pandemia/>. Acesso em: 6 jun. 2020.

GALDAMES-PAREDES, F. J. Análisis econométrico del abastecimiento de medicamentos en el mercado público vía licitaciones, convenios Marco y Cenabast. Dissertação (Mestrado) - Universidade de Chile, Santiago, Chile, 2015. Disponível em: <http://repositorio.uchile.cl/ bitstream/handle/2250/134123/Analisis-econometrico-del-abastecimiento-de-medicamentos-en-el-mercado.pdf?sequence=1\&isAllowed=y>. Acesso em: 6 maio 2020.

GARATTINI, L.; VAN DE VOOREN, K.; CURTO, A. Pricing HPV vaccines, lessons from Italy. Pharmacoeconomics, v. 30, n. 3, p. 213-217, 2012.

GÓMEZ-DANTÉS, O. et al. A new entity for the negotiation of public procurement prices for patented medicines in Mexico. Bulletin of the World Health Organization, v. 90, p. 788792, 2012.

GRIMM, V. et al. Division in lots and competition in procurement. In: DIMITRI, D.; PIGA, G.; SPAGNOLO, G. (Eds.). Handbook of Public Procurement. Cambridge: Cambridge U.P., 2006.

GUCCIO, C.; PIGNATARO, G.; RIZZO, I. Efficiency of procurement procedures for medical devices. Rivista di politica econômica, v. 96, n. 1, p. 135-158, 2006.

KASTANIOTI, C. et al. Public procurement of health technologies in Greece in an era of economic crisis. Health Policy, n. 109, p. 7-13, 2013.

LUNTE, K.; CORDIER-LASSALLEB, T.; KERAVECA, J. Reducing the price of treatment for multidrug-resistant tuberculosis through the Global Drug Facility. Bulletin of the World Health Organization, v. 93, p. 279-282, 2015. 
GRUBERT, N. A landmark for international collaboration on HTA and pharmaceutical pricing. 2018. Disponível em: <https://www.linkedin.com/pulse/landmark-international-collaboration-hta-pricing-neil-grubert/>. Acesso em: 8 maio 2020.

GUERRA NETO, C. et al. Gestáo e inovaçáo em saúde: o que estamos fazendo na Ebserh. Natal: Universidade Federal do Rio Grande do Norte, 2018.

HECKERT, C.; FERNANDES, M.; FENILI, R. As contrataçóes da Lei das Estatais. In: Empresas estatais: políticas públicas, governança e desempenho. Brasília: Ipea, 2019.

HUFF-ROUSSELLE, M. The logical underpinnings and benefits of pooled pharmaceutical procurement: a pragmatic role for our public institutions? Social science $\boldsymbol{\alpha}$ medicine, v. 75 , n. 9, p. 1572-1580, 2012.

HUFF-ROUSSELLE, M.; BURNETT, F. Cost containment through pharmaceutical procurement: a caribbean case study. The International Journal of Health Planning and Management, v. 11, n. 2 , p. $135-157,1996$.

INDERST, R.; MONTEZ, J. Buyer Power and Mutual Dependency in Model Negotiations. Rand Journal of Economics, v. 50, n. 1, p. 29-56, 2019.

INDERST, R.; WEY, C. Buyer Power and Supplier Incentives. European Economic Review, v. 51, p. 647-667, 2007.

JEON, D.-S.; MENICUCCI, D. Buyer Group and Buyer Power When Sellers Compete. CEPR, 2017. (Discussion Paper, n. 12547).

JUSTEN FILHO, M. Comentários à Lei de Licitaçóes e Contratos Administrativos. 11. ed. São Paulo: Dialética, 2005.

. Um novo modelo de licitaçóes e contrataçóes administrativas? In: OLIVEIRA, J.;

PEREIRA; TALAMINI. Covid 19 e o direito brasileiro. 2. ed. 2020.

LUNTE, K.; CORDIER-LASSALLEB, T.; KERAVECA, J. Reducing the price of treatment for multidrug-resistant tuberculosis through the Global Drug Facility. Bulletin of the World Health Organization, v. 93, p. 279-282, 2015.

MIRANDA, H. S. Compra direta de passagens aéreas. Coleção Casos Seges: renovando a gestão pública. Brasília: Enap, 2018. Disponível em: <https://repositorio.enap.gov.br/handle/1/3460>. Acesso em: 12 abr. 2020.

NHS - NATIONAL HEALTH SERVICE. Better Procurement, Better Value, Better Care: A Procurement Development Programme for the NHS. London: Department of Health and NHS, 2013. Disponível em: <https://assets.publishing.service.gov.uk/government/uploads/system/uploads/attachment_data/file/226835/procurement_development_programme_for_NHS. pdf>. Acesso em: 19 jun. 2020.

74 
NÓBREGA, M.; TORRES, R. C. Licitaçôes públicas e e-marketplace: um sonho não tão distante. In: O Licitante. 2020. Disponível em: <http://www.olicitante.com.br/marketplace-sonho-distante/\#_ftn32>. Acesso em: 25 maio 2020.

OCDE - ORGANIZAÇÃO PARA A COOPERAÇÃO E DESENVOLVIMENTO ECONÔMICO. Colombia: Implementing Good Governance. OECD Public Governance Reviews, OECD Publishing, Paris, 2013. Disponível em: <http://dx.doi.org/10.1787/9789264202177-en>.

. Public Procurement in Chile: Policy Options for Efficient and Inclusive Framework Agreements, OECD Public Governance Reviews. Paris: OECD Publishing, 2017. Disponível em: <http://dx.doi.org/10.1787/9789264275188-en>.

SMEs in Public Procurement: Practices and Strategies for Shared Benefits. OECD Public Governance Reviews, OECD Publishing, Paris, 2018. Disponível em: <https://doi. org/10.1787/9789264307476-en>.

. Public Procurement responses to the Covid-19: lessons and experiences from countries. OECD Webinar. 2020a. Disponível em: <https://www.youtube.com/watch?v=QS3p5DYQ9rk>. Acesso em: 4 jun. 2020.

Centralised and Decentralised Public Procurement. Paris: OECD Publishing, 2020b. (Sigma Papers, n. 29). Disponível em: <https://doi.org/10.1787/5kml60w5dxr1-en>.

OLIVEIRA, R. Licitaçóes inclusivas: os impactos do Estatuto da Pessoa com Deficiência nas contrataçóes públicas. 2015. Disponível em: <http://genjuridico.com.br/2015/07/27/licitacoes-inclusivas-os-impactos-do-estatuto-da-pessoa-com-deficiencia-nas-contratacoes-publicas/>. Acesso em: 1으 maio 2020.

OLLAIK, L. G. TáxiGov: inovando no serviço de mobilidade de servidores. Coleção Casos Seges: renovando a gestão pública. Brasília: Enap, 2018. Disponível em: <https://repositorio. enap.gov.br/handle/1/3454>. Acesso em: 12 abr. 2020.

O’MAHONY, J. F. Beneluxa: What are the Prospects for Collective Bargaining on Pharmaceutical Prices Given Diverse Health Technology Assessment Processes? PharmacoEconomics 37, p. 627-630, 2019.

PEDRA, A.; OLIVEIRA, R.; TORRES, R. A mística da impossibilidade de pagamento antecipado pela administraçáo pública. 2020. Disponível em: <https://ronnycharles.com. br/a-mistica-da-impossibilidade-de-pagamento-antecipado-pela-administracao-publica/>. Acesso em: 6 jun. 2020.

PEREIRA JÚNIOR, N. Política, planejamento e gestão em Hospitais Universitários Federais. Tese (Doutorado em Saúde Coletiva) - Universidade Estadual de Campinas, Campinas, 2018.

PETROU, P.; TALIAS, M. A. Tendering for pharmaceuticals as a reimbursement tool in the Cyprus public health sector. Health Policy and Technology, v. 3, n. 3, p. 167-175, 2014. 
RIBEIRO, C. G.; INÁCIO JÚNIOR, E. O mercado de compras governamentais brasileiro (2006-2017): mensuração e análise. Brasília: Ipea, 2019. (Texto para Discussão, n. 2476).

RAVENTÓS, P.; ZOLEZZI, S. Electronic tendering of pharmaceuticals and medical devices in Chile. Journal of Business Research, v. 68, n. 12, p. 2569-2578, 2015.

RIZZO, C. G. G. P. I. Efficiency of procurement procedures for medical devices. Rivista di politica economica, v. 96, n. 1-4, p. 135, 2006.

ROSE-ACKERMAN, S.; YAN, Y. Corruption in the Procurement of Pharmaceuticals and Medical Equipment in China. UCLA Pac. Basin LJ, v. 32, n. 1, 2014.

SANTOS, F. Compras públicas centralizadas: a experiência da Empresa Brasileira de Serviços Hospitalares. 257 f. Dissertação (Mestrado Profissional em Governança e Desenvolvimento) Escola Nacional de Administração Pública, Brasília, 2019.

TOLEDO, R. Coronavírus e o laboratório das contrataçóes públicas. 2020. Disponível em: <https://www.jota.info/opiniao-e-analise/colunas/reg/coronavirus-e-o-laboratorio-das-contratacoes-publicas-16042020>.

UNCITRAL - UNITED NATIONS COMMISSION ON INTERNATIONAL TRADE LAW. Model Law of Public Procurement. 2011. Disponível em: <https://www.uncitral.org/ pdf/english/texts/procurem/ml-procurement-2011/2011-Model-Law-on-Public-Procurement-e. pdf .< Acesso em: 5 jun. 2020.

VOGLER, S. et al. Discounts and rebates granted for medicines for hospital use in five European countries. The Open Pharmacoeconomics \& Health Economics Journal, v. 5, n. 1, 2013.

WANING, B. et al. Global strategies to reduce the price of antiretroviral medicines: evidence from transactional databases. Bulletin of the World Health Organization, v. 87, p. 520-528, 2009. Disponível em: <https:/www.who.int/bulletin/volumes/87/7/08-058925/en/>.

WHO - ORGANIZAÇÃO MUNDIAL DA SAÚDE. Challenges and opportunities in improving access to medicines through efficient public procurement in the WHO European Region. Genebra, 2016.

Rational use of personal protective equipment (PPE) for coronavirus disease (Covid-19). Interim Guidance, 19 Mar. 2020. Disponível em: <https://apps.who.int/iris/ handle/10665/331498>. Acesso em: 4 jun. 2020.

WOUTERS, O. J. et al. The impact of pharmaceutical tendering on prices and market concentration in South Africa over a 14-year period. Social Science \& Medicine, n. 220, p. 362-370, 2019.

YAO, Y.; TANAKA, M. Price offers of pharmaceutical procurement in China: evidence from Guangdong province. The European Journal of Health Economics, v. 17, n. 5, p. 563-575, 2016. 


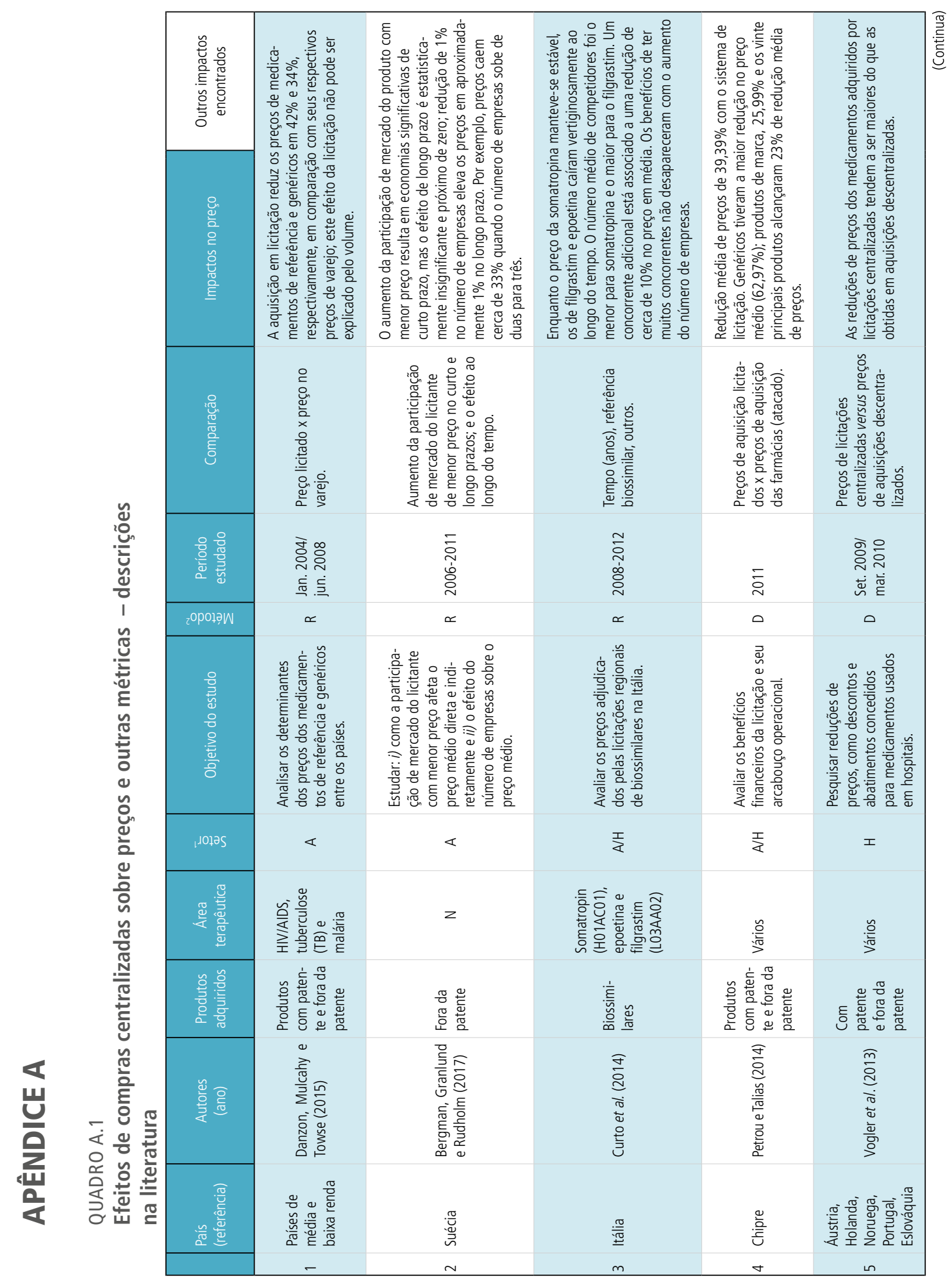




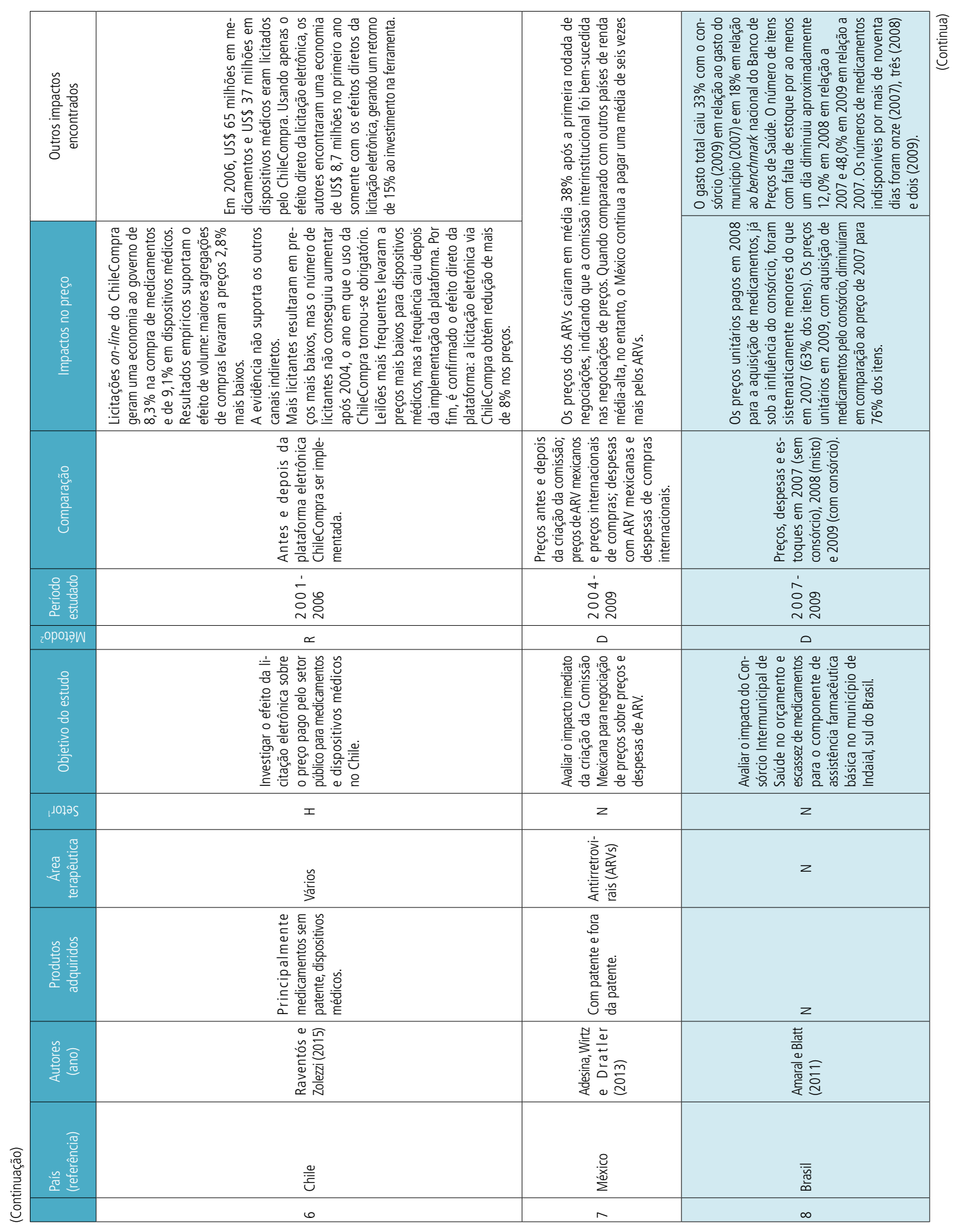




\begin{tabular}{|c|c|c|c|c|c|}
\hline 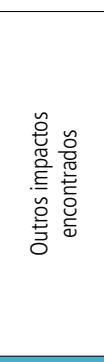 & 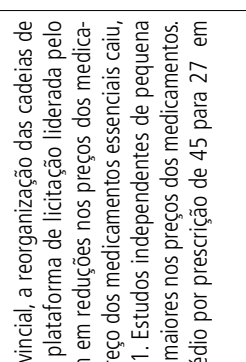 & 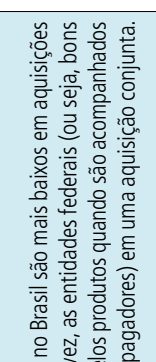 & 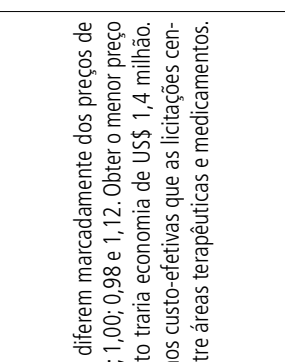 & 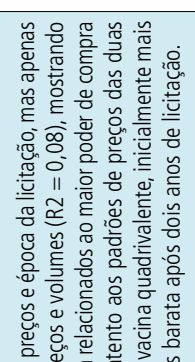 & 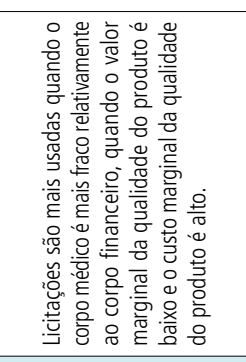 \\
\hline 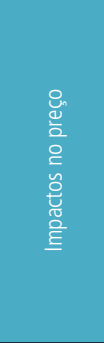 & 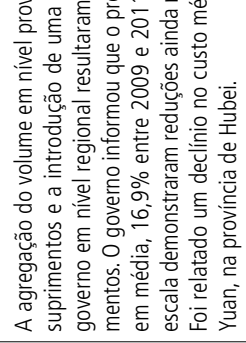 & 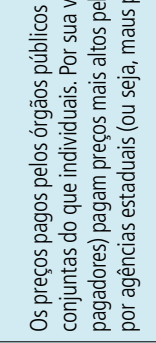 & 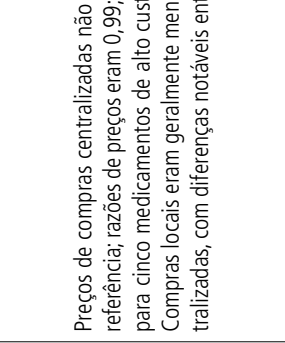 & 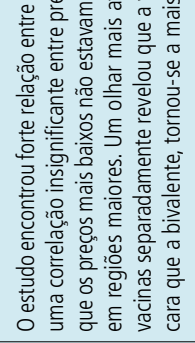 & \\
\hline 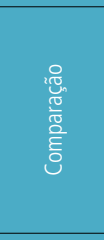 & 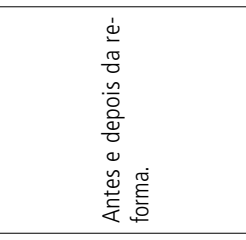 & 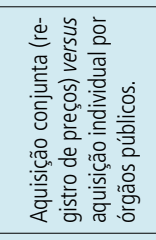 & 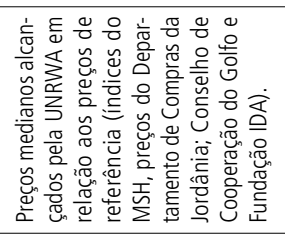 & 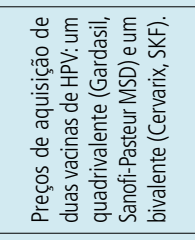 & 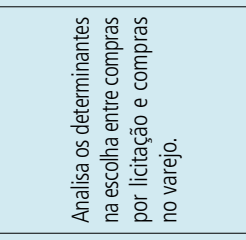 \\
\hline 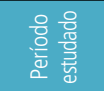 & $\frac{\pi}{z}$ & $\begin{array}{l}\dot{\dot{d}} \\
\stackrel{\circ}{\circ} \\
\stackrel{\circ}{\circ}\end{array}$ & $\stackrel{\circ}{\circ}$ & ì & 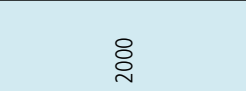 \\
\hline 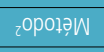 & 0 & $\propto$ & 0 & $\propto$ & $\propto$ \\
\hline 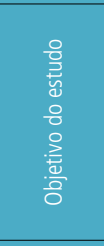 & 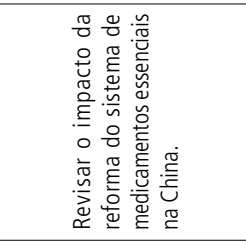 & 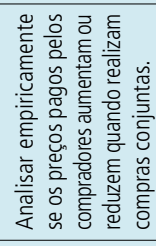 & 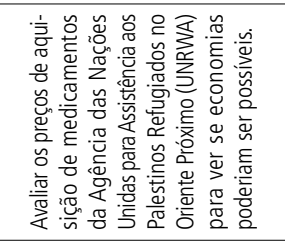 & 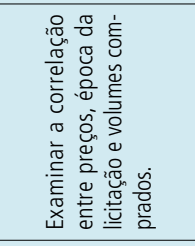 & 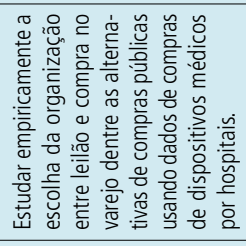 \\
\hline t.0ㄹㅇㅗ & $z$ & $z$ & $z$ & $z$ & $I$ \\
\hline 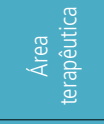 & $z$ & z & 总总 & 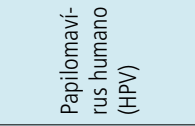 & $z$ \\
\hline & $z$ & $z$ & $z$ & 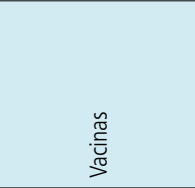 & 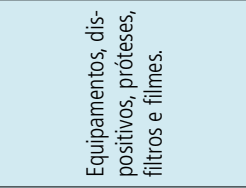 \\
\hline 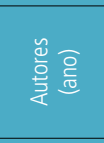 & 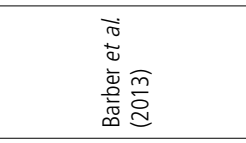 & 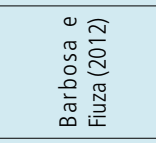 & 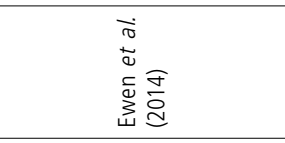 & 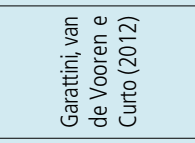 & 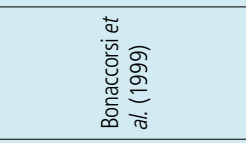 \\
\hline 恶 & 莺 & $\overline{\overline{\bar{m}}}$ & 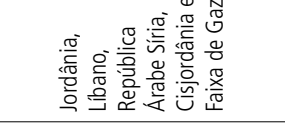 & $\frac{\sqrt{\frac{0}{\pi}}}{\underline{\underline{\pi}}}$ & $\frac{\sqrt{\frac{0}{\pi}}}{\underline{\underline{\pi}}}$ \\
\hline 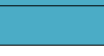 & $a$ & 으 & $=$ & $\simeq$ & $\stackrel{m}{\sim}$ \\
\hline
\end{tabular}




\begin{tabular}{|c|c|c|c|}
\hline 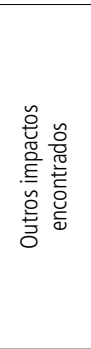 & 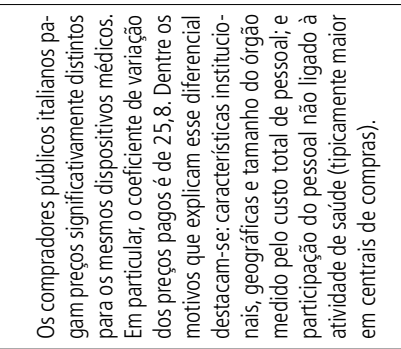 & \multirow{2}{*}{ 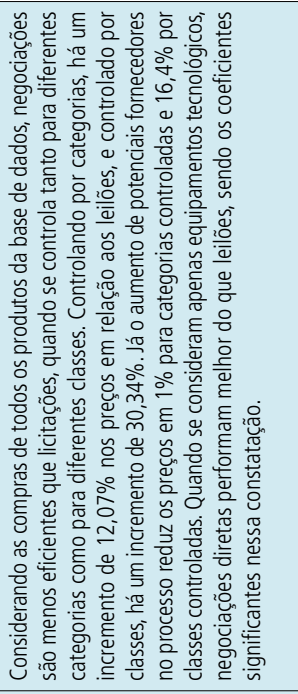 } & 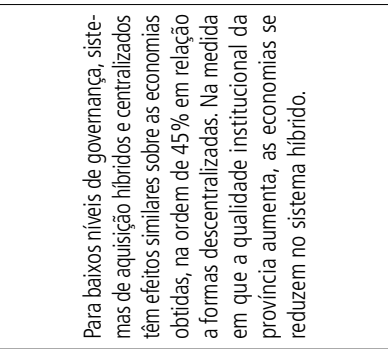 \\
\hline 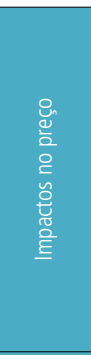 & 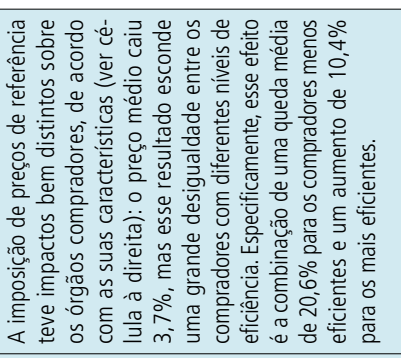 & & 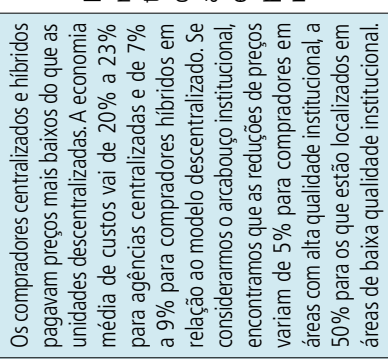 \\
\hline 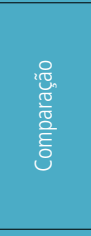 & 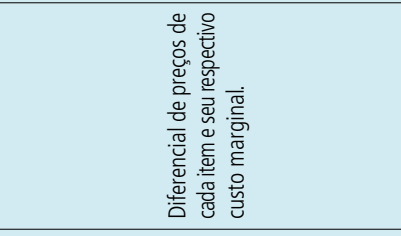 & 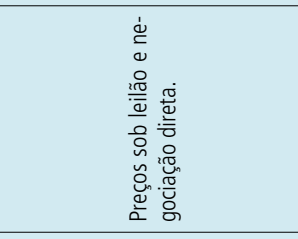 & 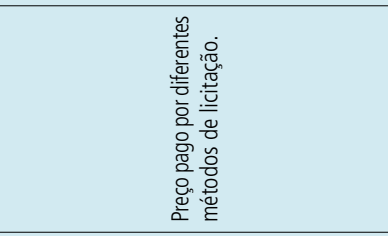 \\
\hline 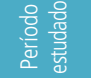 & 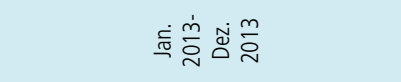 & 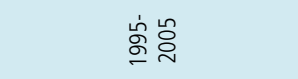 & 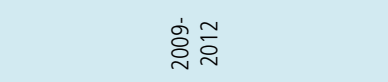 \\
\hline zopoləow & $\propto$ & $\propto$ & $\simeq$ \\
\hline 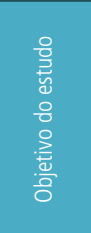 & 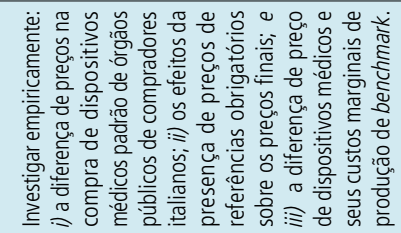 & 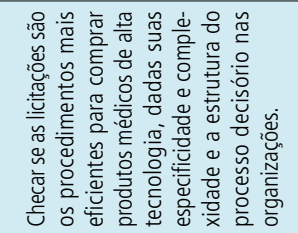 & 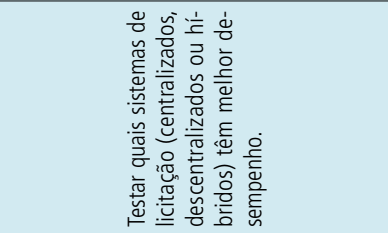 \\
\hline tolas & $z$ & I & \pm \\
\hline 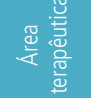 & $z$ & 茑 & $z$ \\
\hline 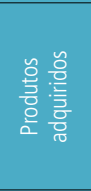 & 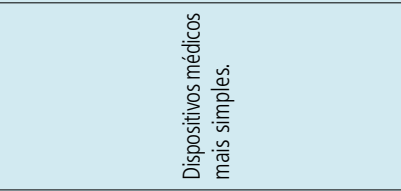 & 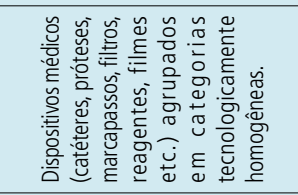 & $z$ \\
\hline 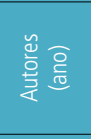 & 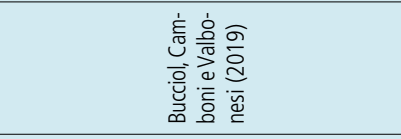 & 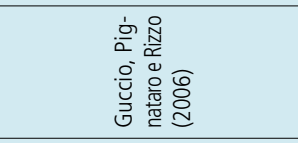 & 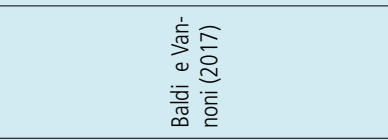 \\
\hline 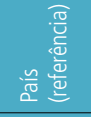 & : & 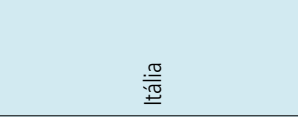 & $\frac{\underline{\underline{0}}}{\underline{\underline{\pi}}}$ \\
\hline & \pm & $\stackrel{n}{\check{n}}$ & 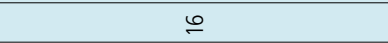 \\
\hline
\end{tabular}




\begin{tabular}{|c|c|c|}
\hline 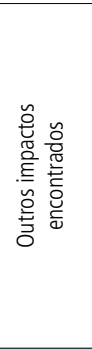 & & 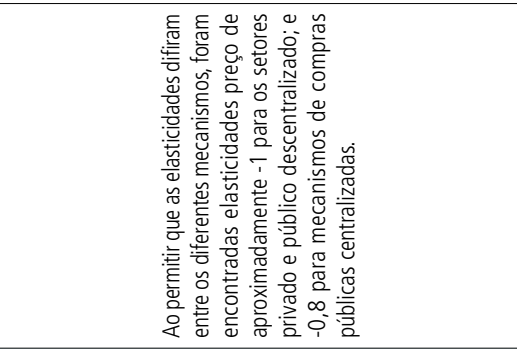 \\
\hline 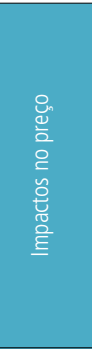 & 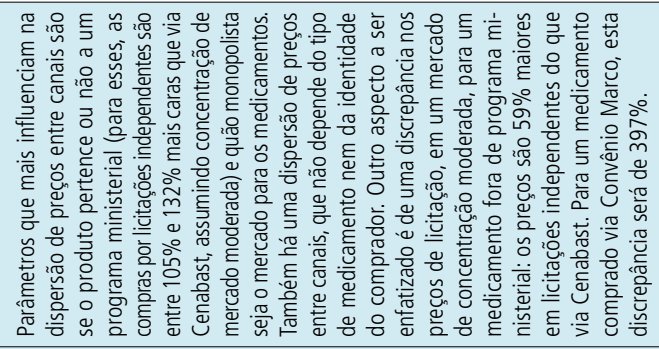 & 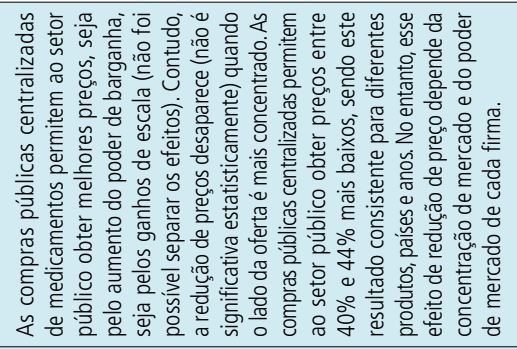 \\
\hline 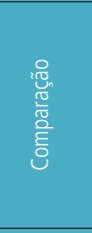 & 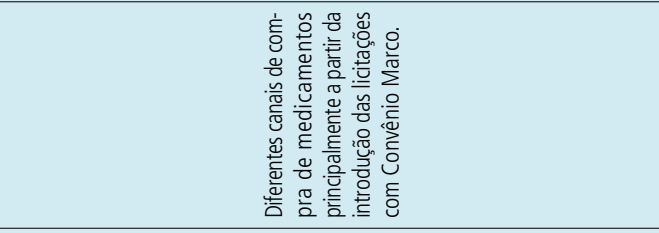 & 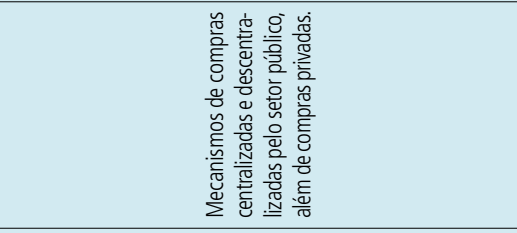 \\
\hline 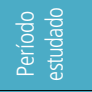 & 言总㤩空 & 官市 \\
\hline zopoləaN & $\propto$ & $\propto$ \\
\hline 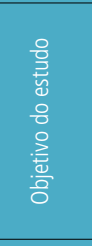 & 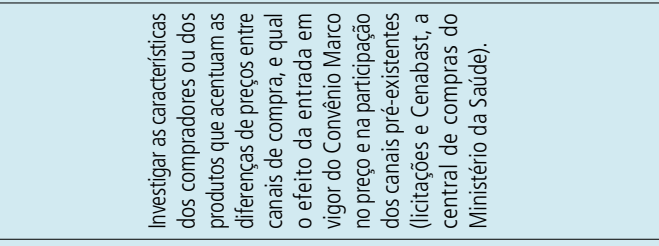 & 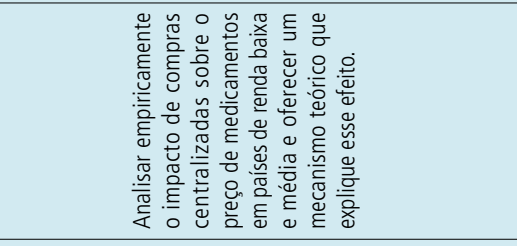 \\
\hline ¿이코 & $\varangle$ & 咅 \\
\hline 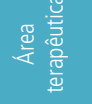 & 崖 & 芯 \\
\hline 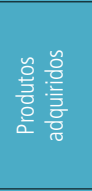 & 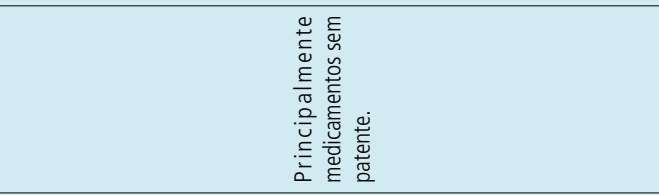 & 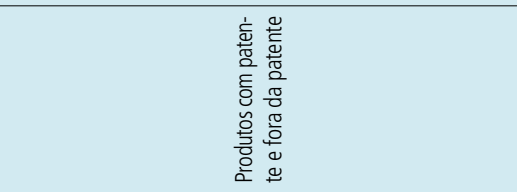 \\
\hline 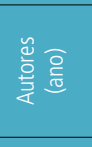 & 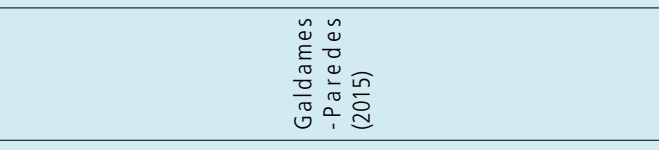 & 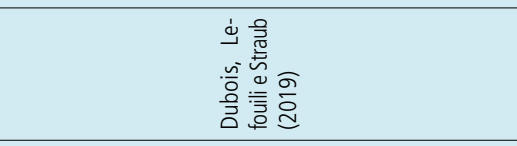 \\
\hline 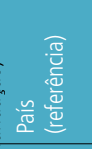 & 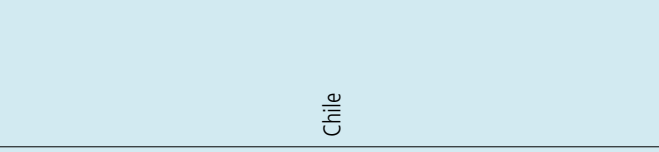 & 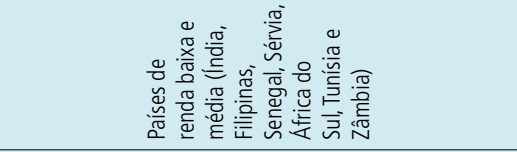 \\
\hline & $=$ & $\simeq$ \\
\hline
\end{tabular}




\begin{tabular}{|c|c|c|c|}
\hline \multirow[t]{2}{*}{ 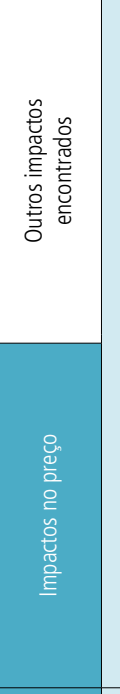 } & \multirow{2}{*}{ 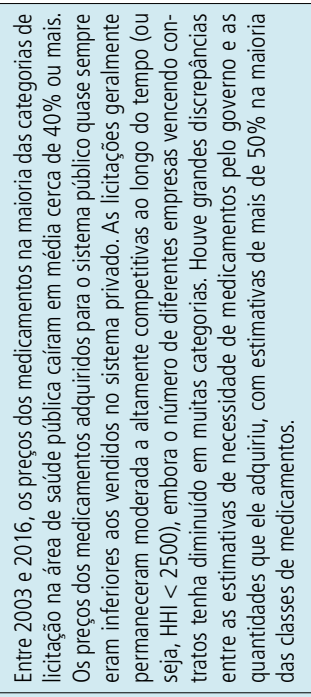 } & \multirow{2}{*}{ 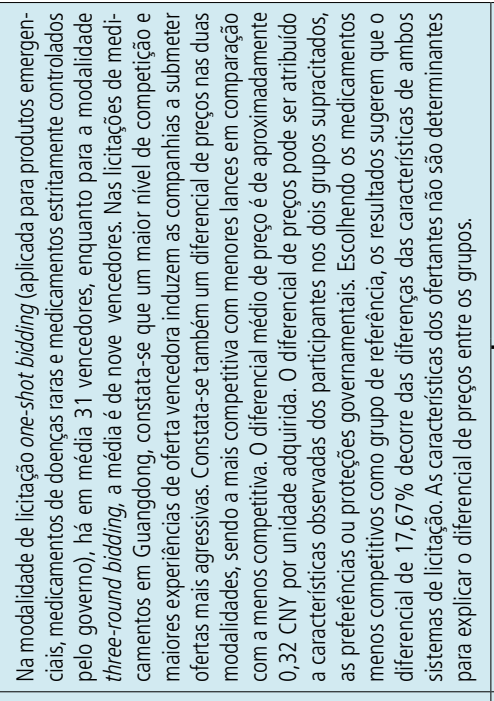 } & 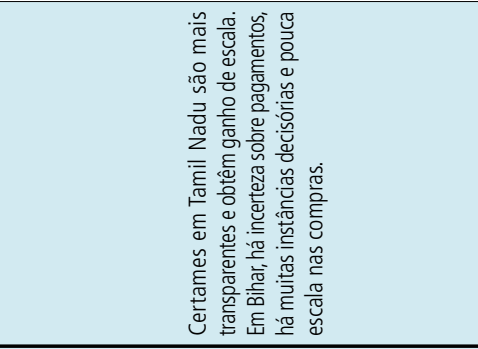 \\
\hline & & & 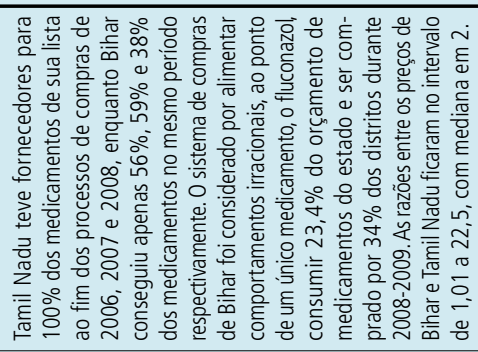 \\
\hline 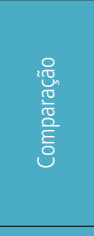 & 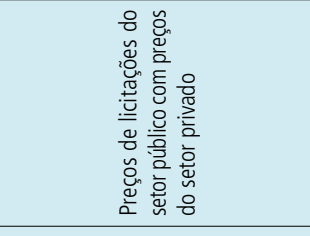 & 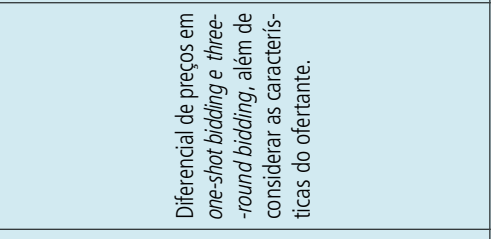 & 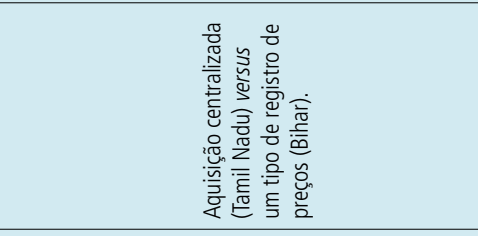 \\
\hline 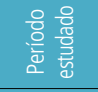 & ஜ்்̀ & 客宫 & 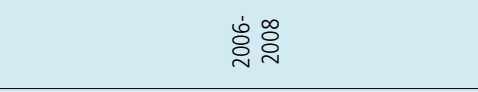 \\
\hline ¿0potian & 0 & $\propto$ & 0 \\
\hline 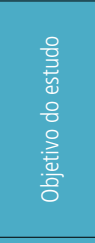 & 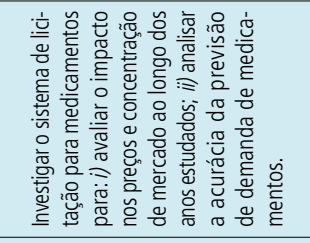 & 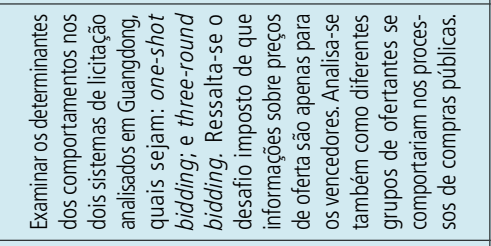 & 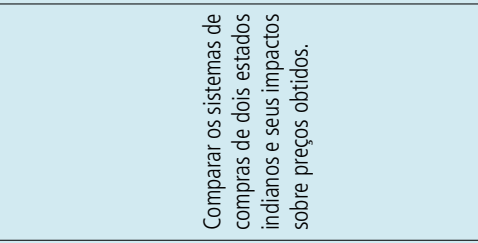 \\
\hline t.jas & $z$ & $z$ & $z$ \\
\hline 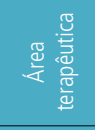 & 峁 & 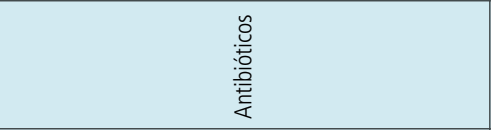 & 总 \\
\hline 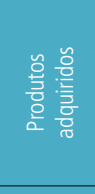 & 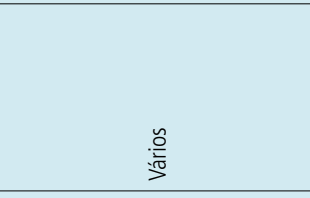 & 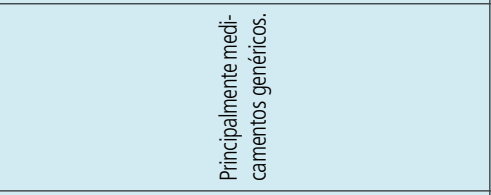 & 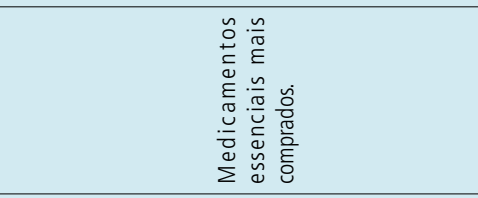 \\
\hline 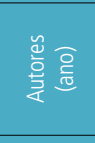 & 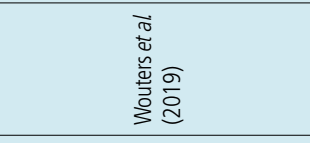 & 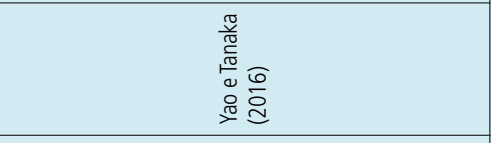 & 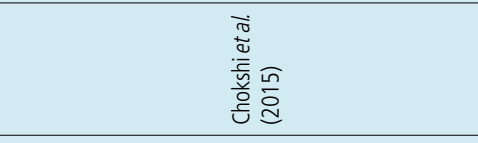 \\
\hline 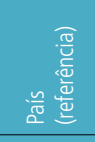 & 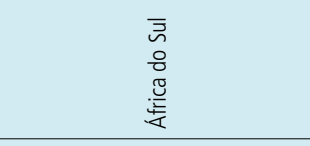 & 总 & 을 \\
\hline & $\stackrel{9}{2}$ & 2 & $\bar{\sim}$ \\
\hline
\end{tabular}




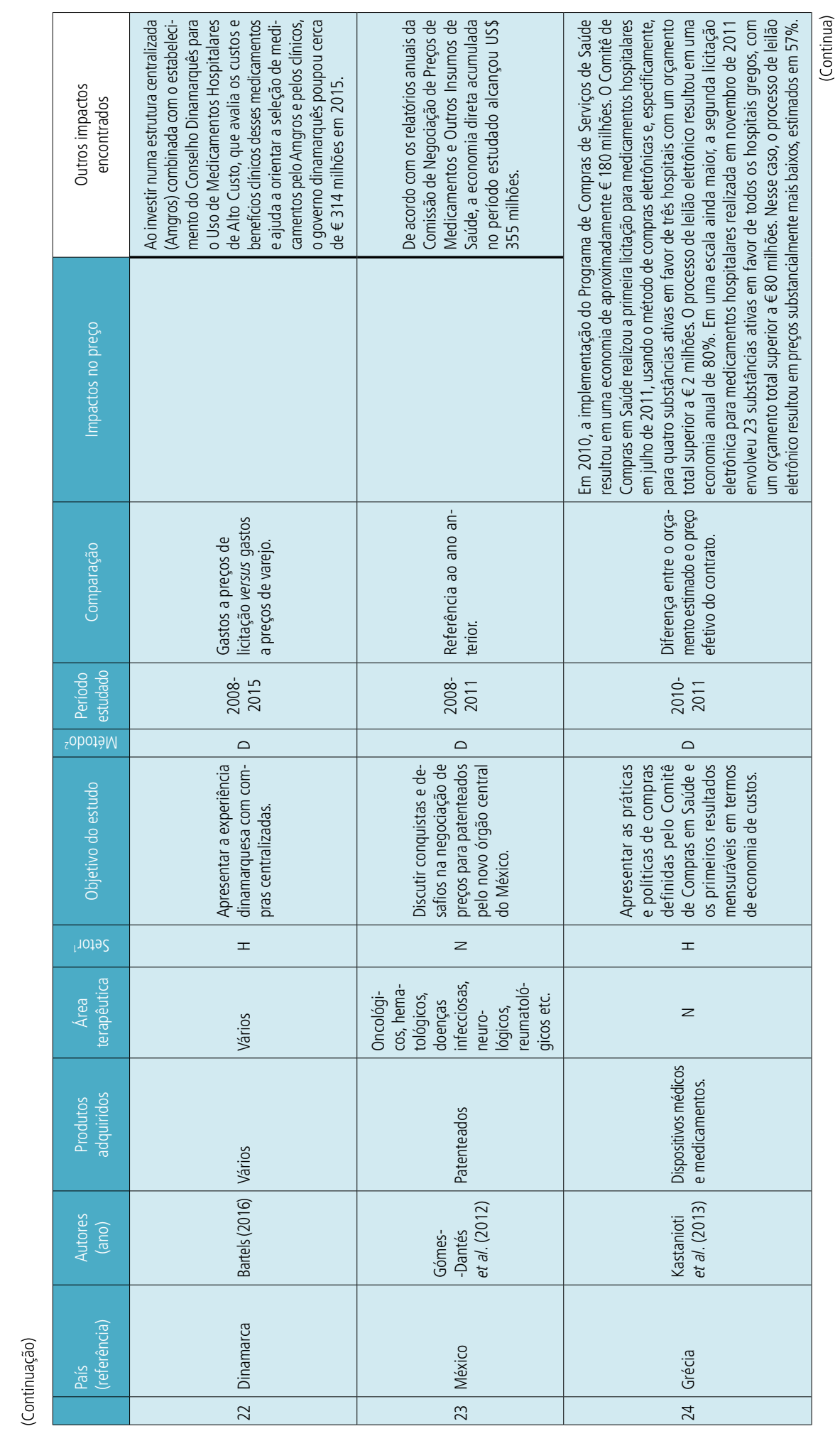




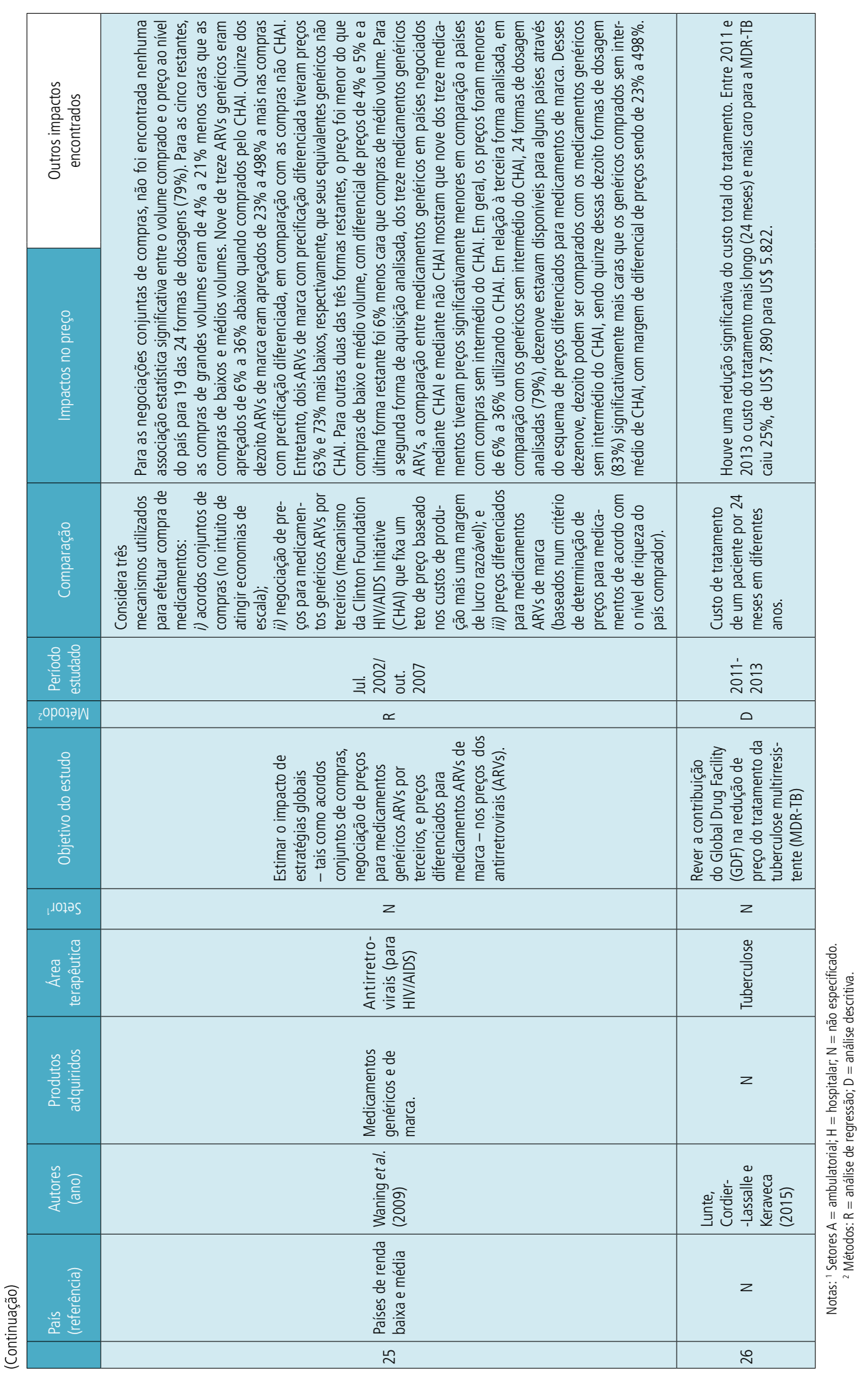

84 
FIGURA A.1

Quantidades de itens de compras/unidades participantes, por órgão - participação no total anual, por classe

Classe 14240 - Equipamento para segurança e salvamento
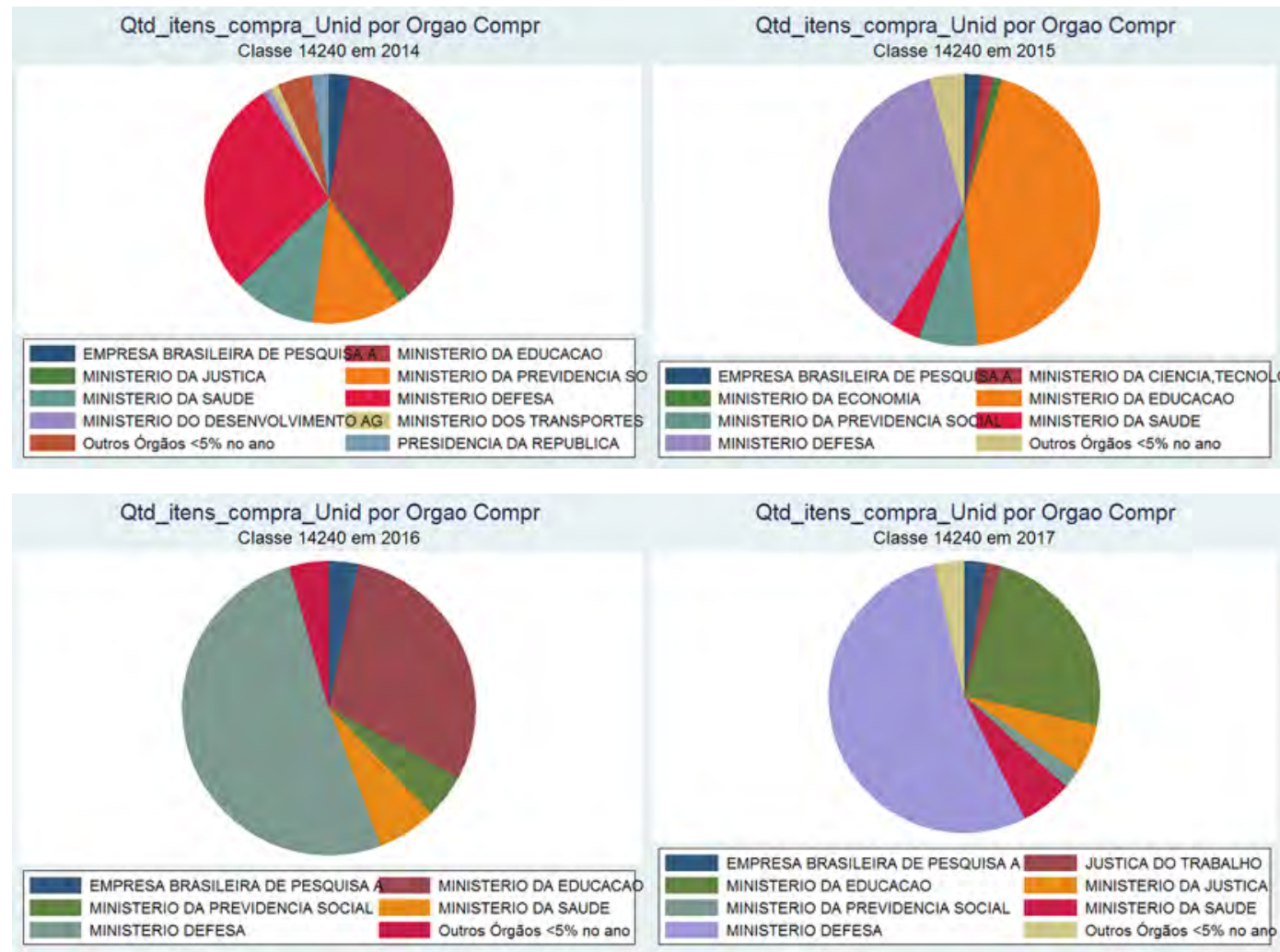

Qtd_itens_compra_Unid por Orgao Compr Classe 14240 em 2017
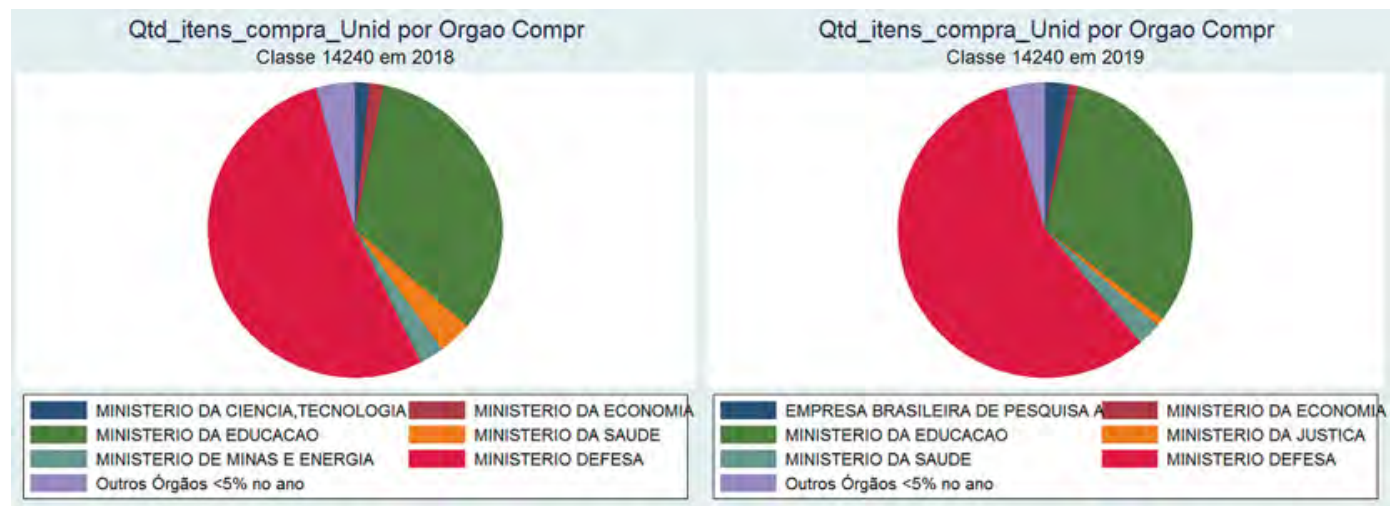
Classe 16505 - Drogas e medicamentos

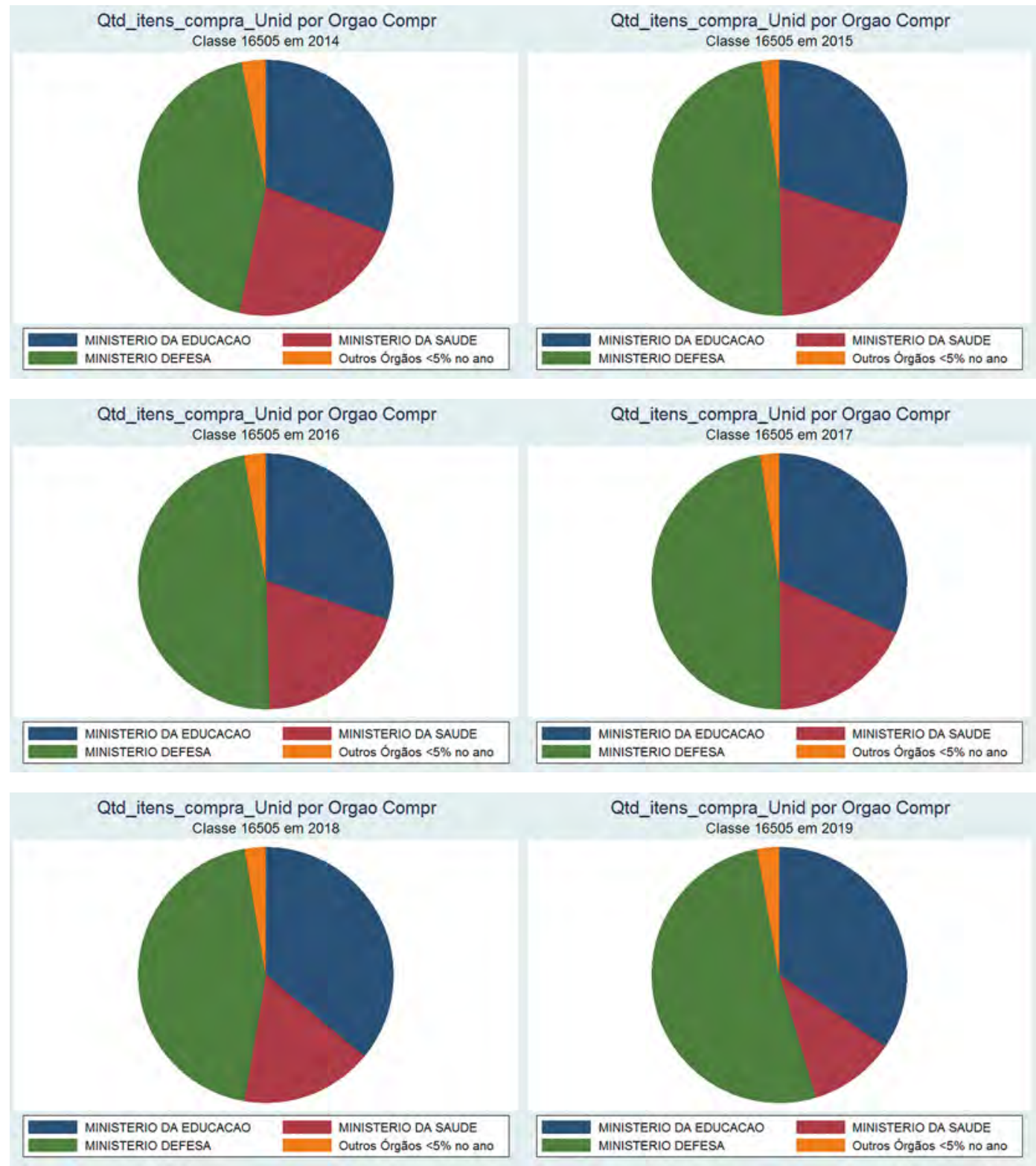


Classe 16515 - Instrumentos, equipamentos e suprimentos médicos e cirúrgicos
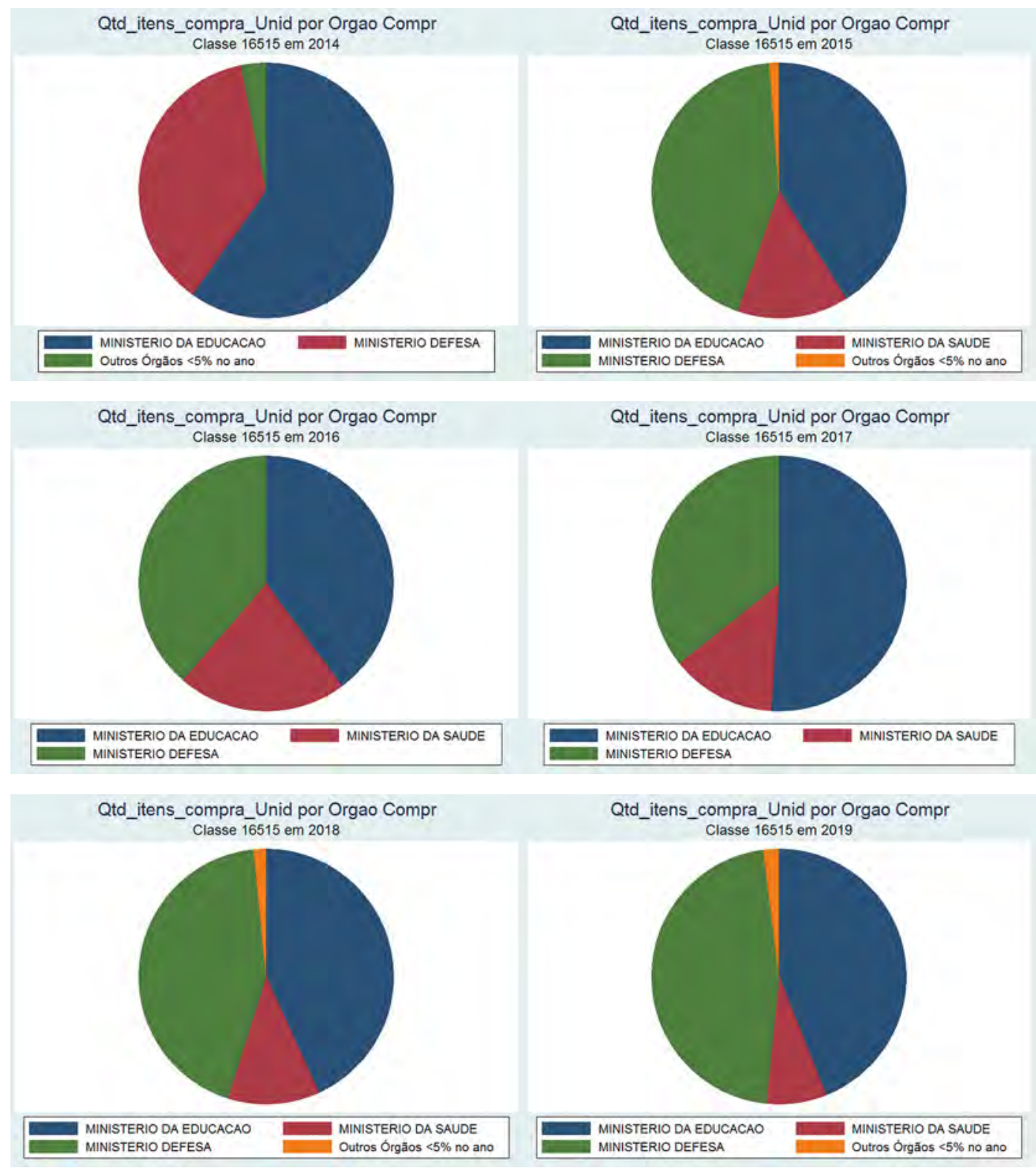
Classe 16532 - Vestuário hospitalar e cirúrgico e itens correlatos de finalidades especiais
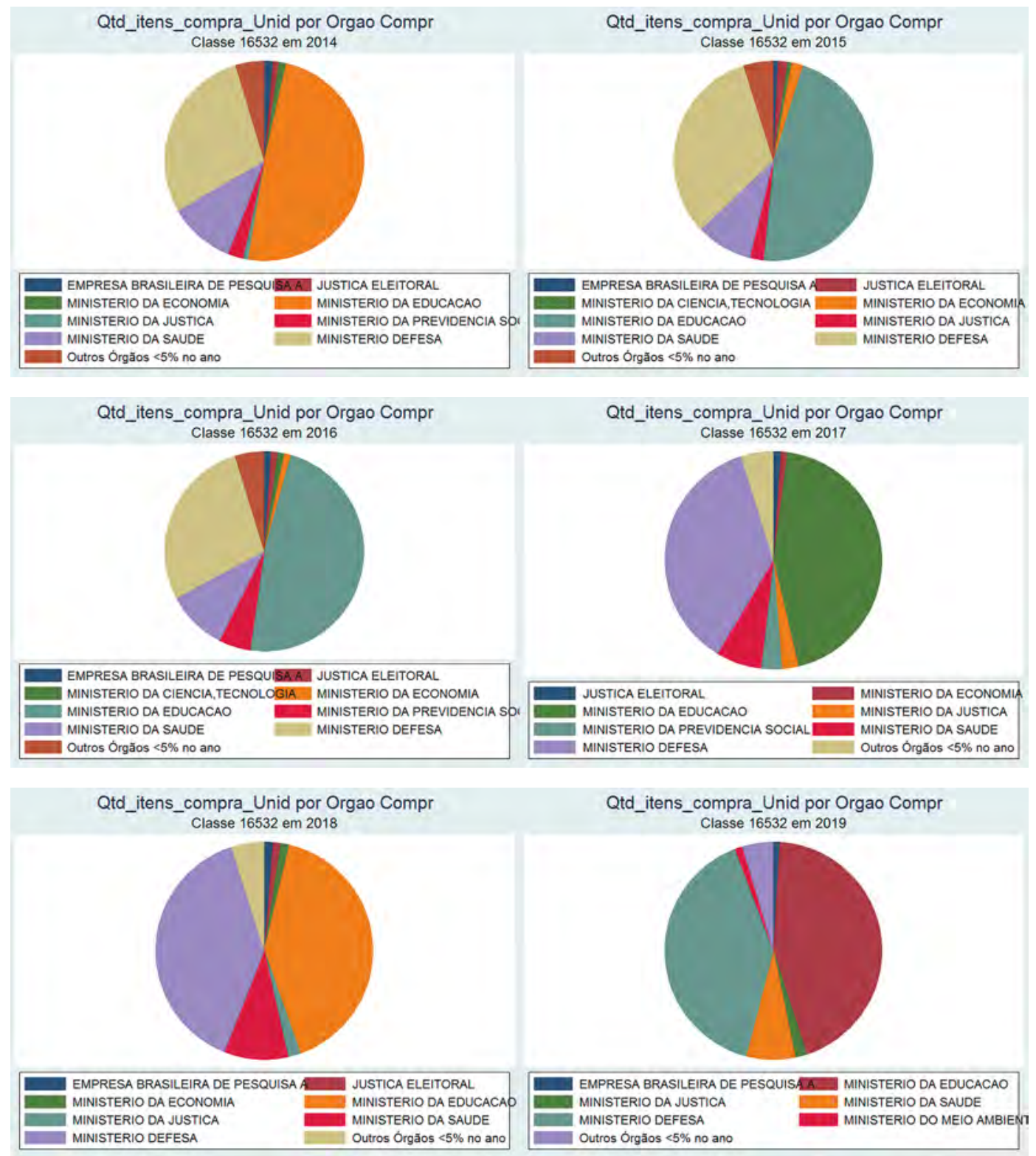
Texto para

Discussão

2575 Compras Públicas Centralizadas em Situações de Emergência e Calamidade Pública

Classe 16810 - Produtos químicos

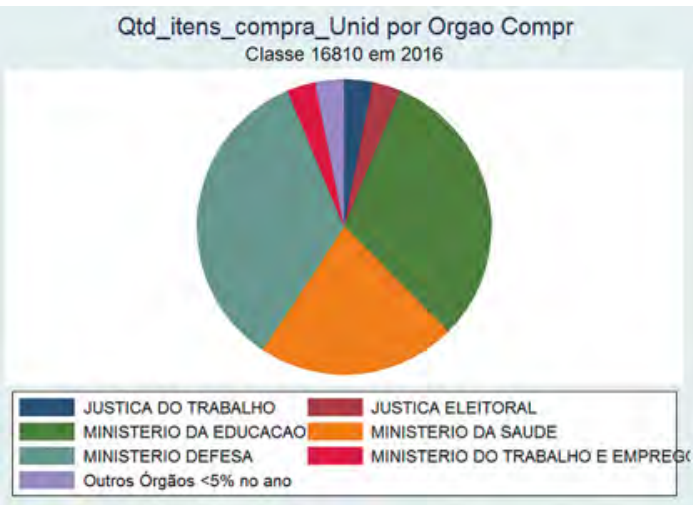

Qtd_itens_compra_Unid por Orgao Compr
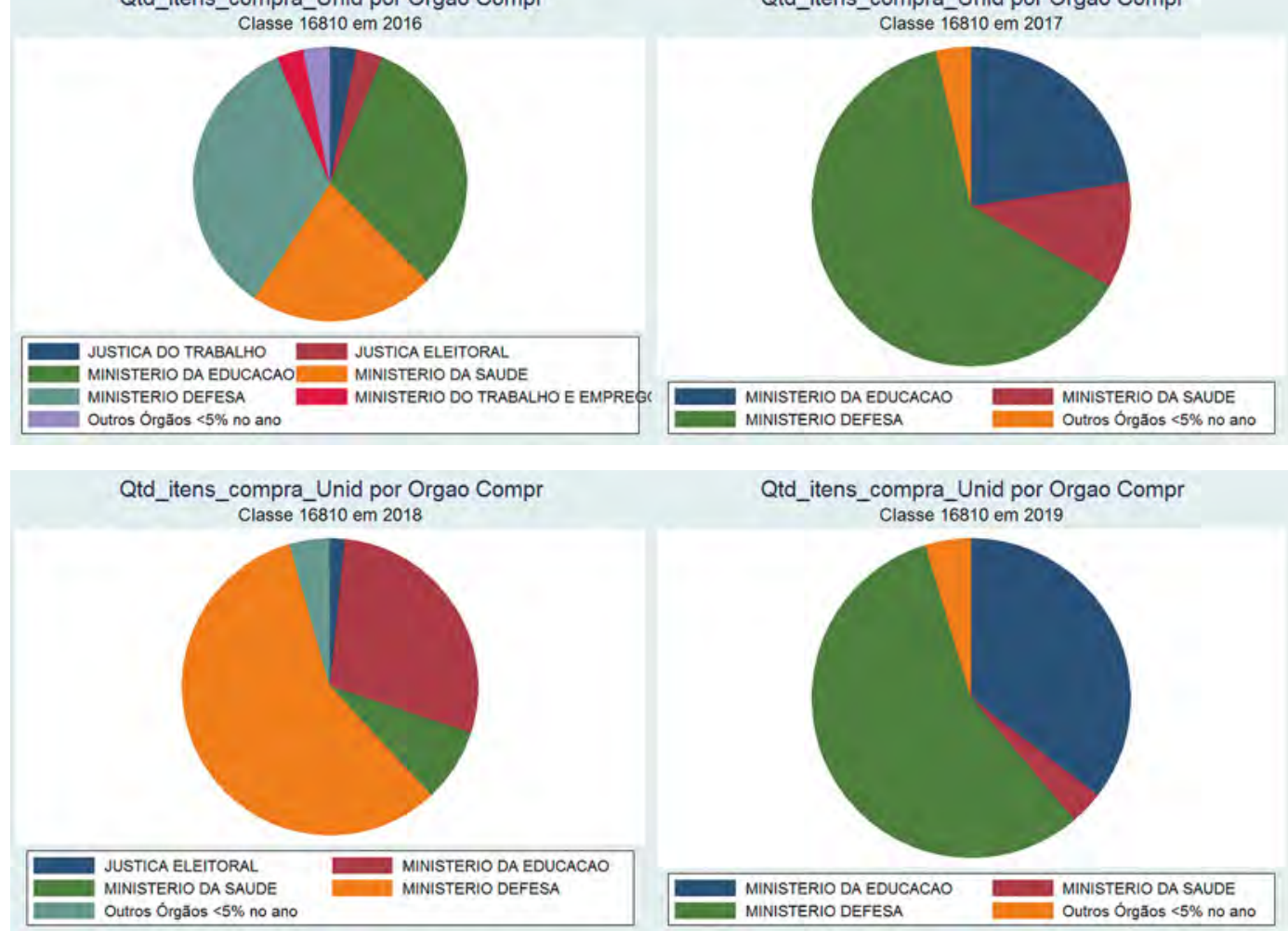
Classe 18105 - Sacos e bolsas

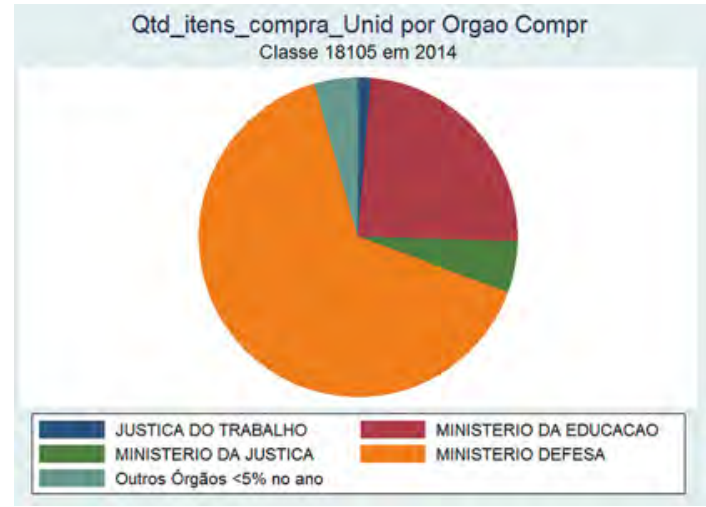

Qtd_itens_compra_Unid por Orgao Compr Classe 18105 em 2015

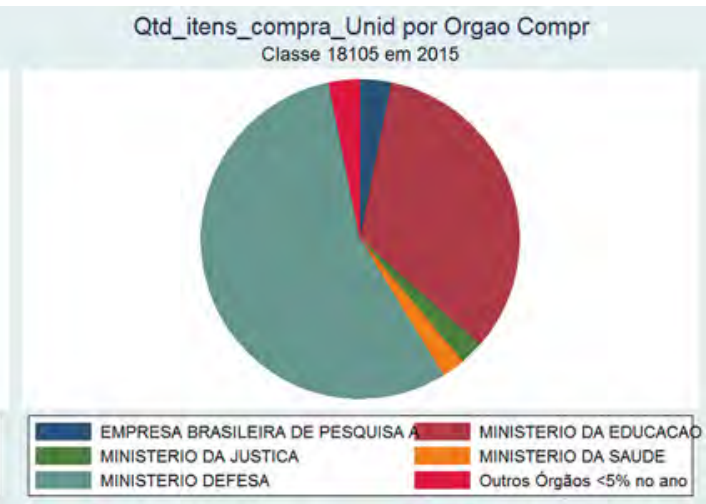

MINSTERIO DA EDUCACAO

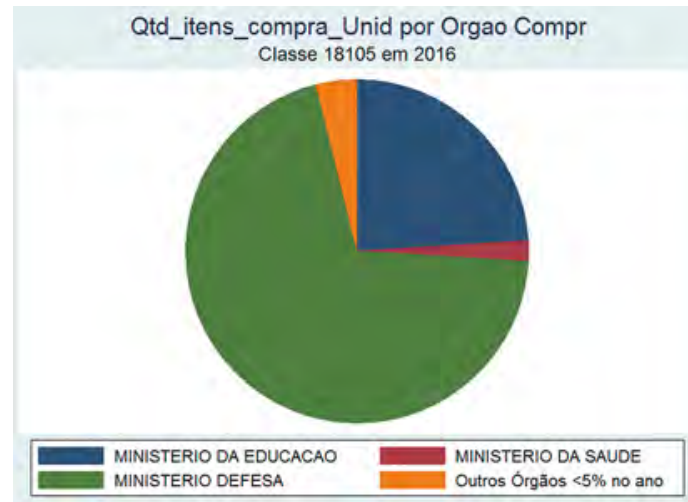

Qtd_itens_compra_Unid por Orgao Compr

MINISTERIO DEFESA

Outros Órgăos $<5 \%$ no ano

MINISTERIO DA EDUCACAO MINISTERIO DEFESA

Outros Örgăos $45 \%$ no ano

Qtd_itens_compra_Unid por Orgao Compr Classe 18105 em 2018

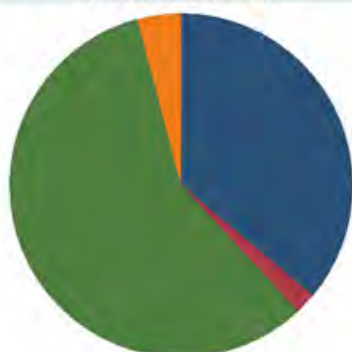

MINISTERIO DA EDUCACAO MINISTERIO DEFESA
Qtd_itens_compra_Unid por Orgao Compr Classe 18105 em 2019

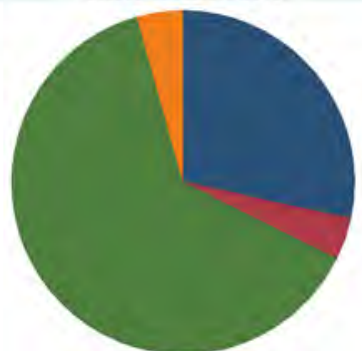

MINISTERIO DA EDUCACAO MINISTERIO DEFESA
MINISTERIO DA SAUDE Outros Órgăos $<5 \%$ no ano 
Classe 18520 - Sabonetes, artigos para barbear e dentifrícios

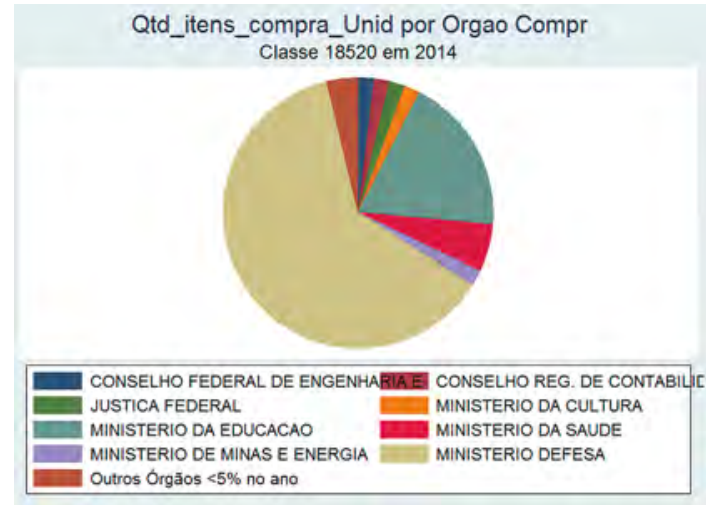

Qtd_itens_compra_Unid por Orgao Compr Classe 18520 em 2014
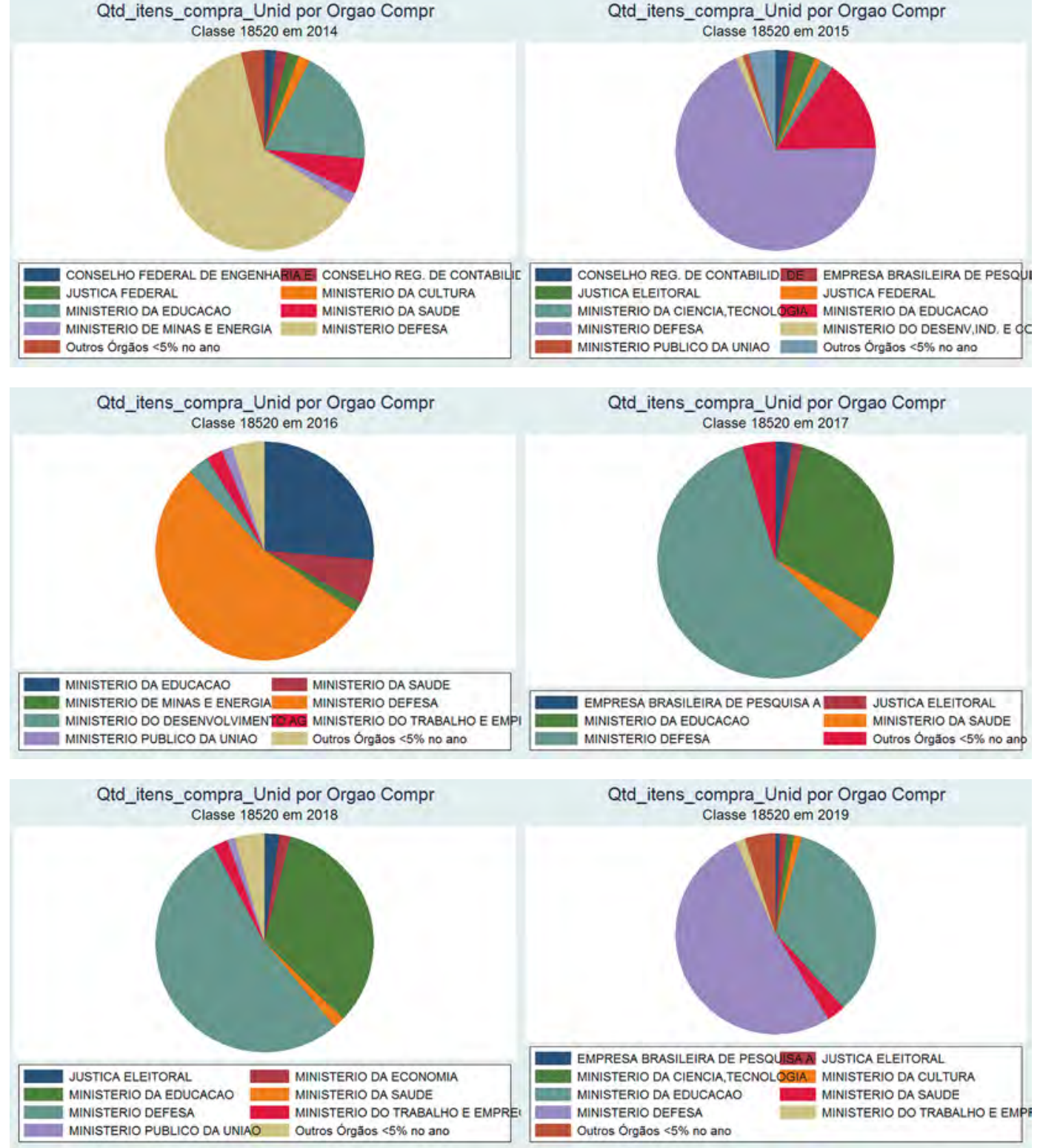
Classe 18540 - Artigos de papel para higiene

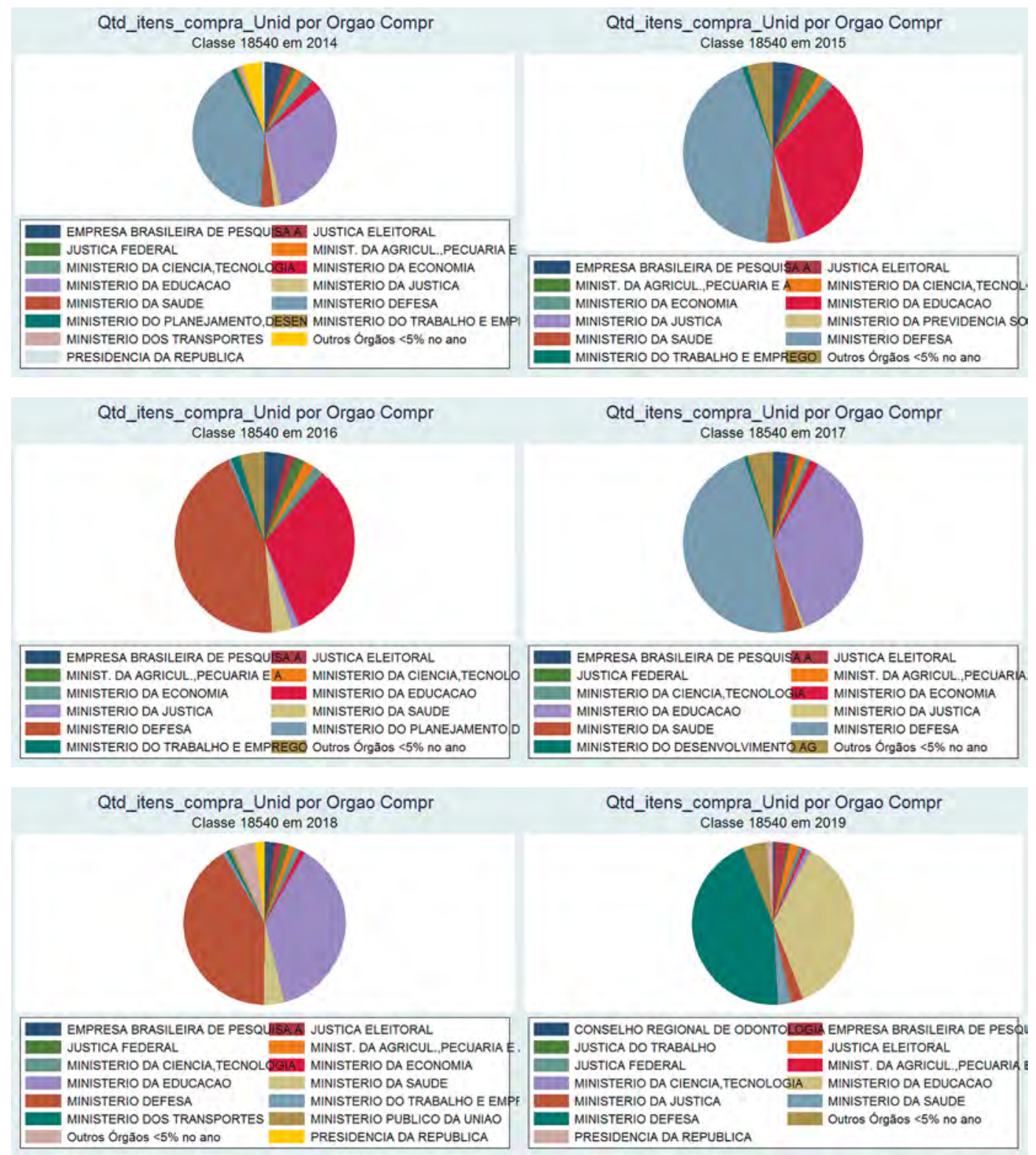


FIGURA A.2

Quantidades de itens de compras/unidades participantes, por órgão - participação no total anual, por classe

Classe 14240 - Equipamento para segurança e salvamento
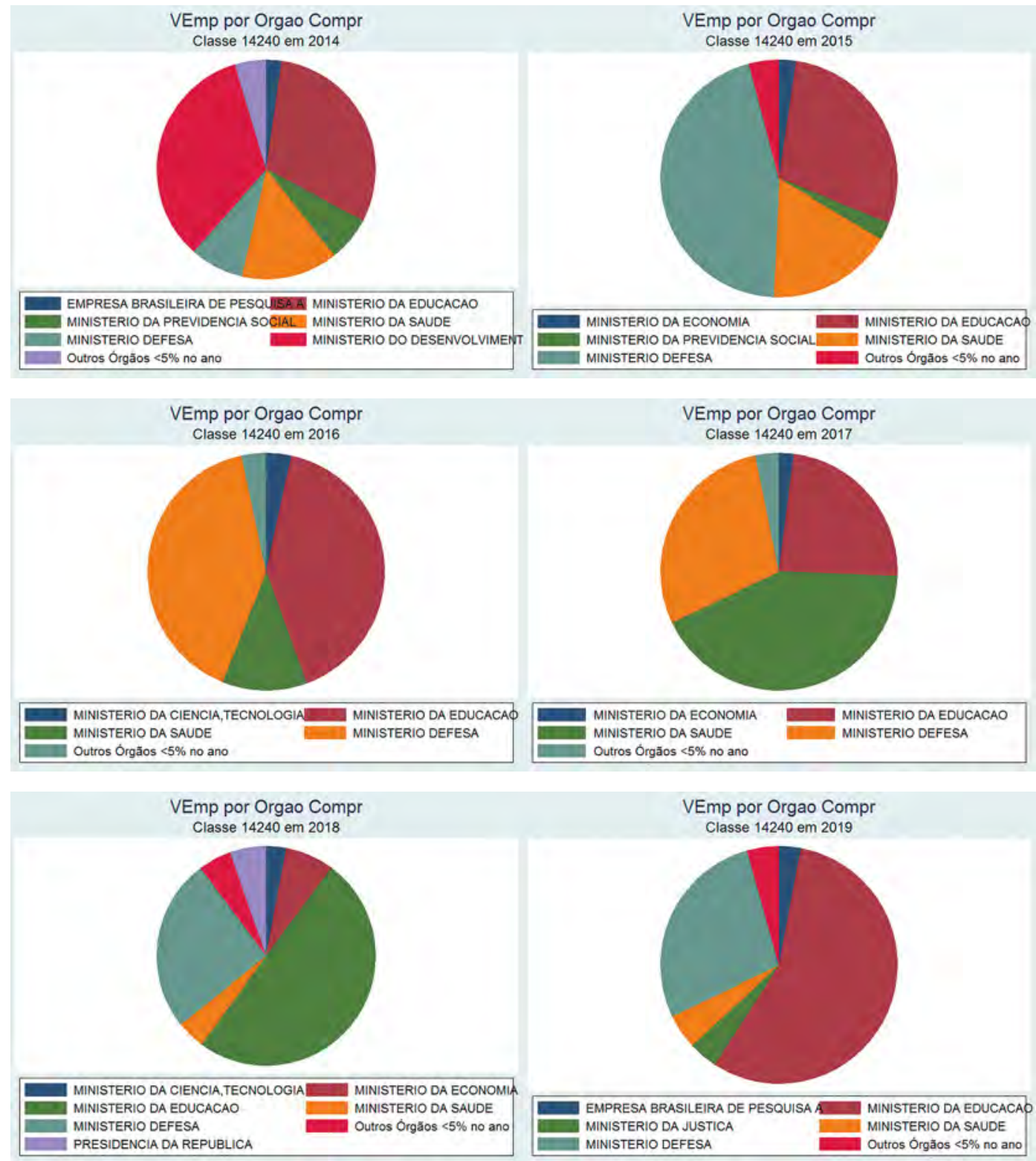
Classe 16505 - Drogas e medicamentos

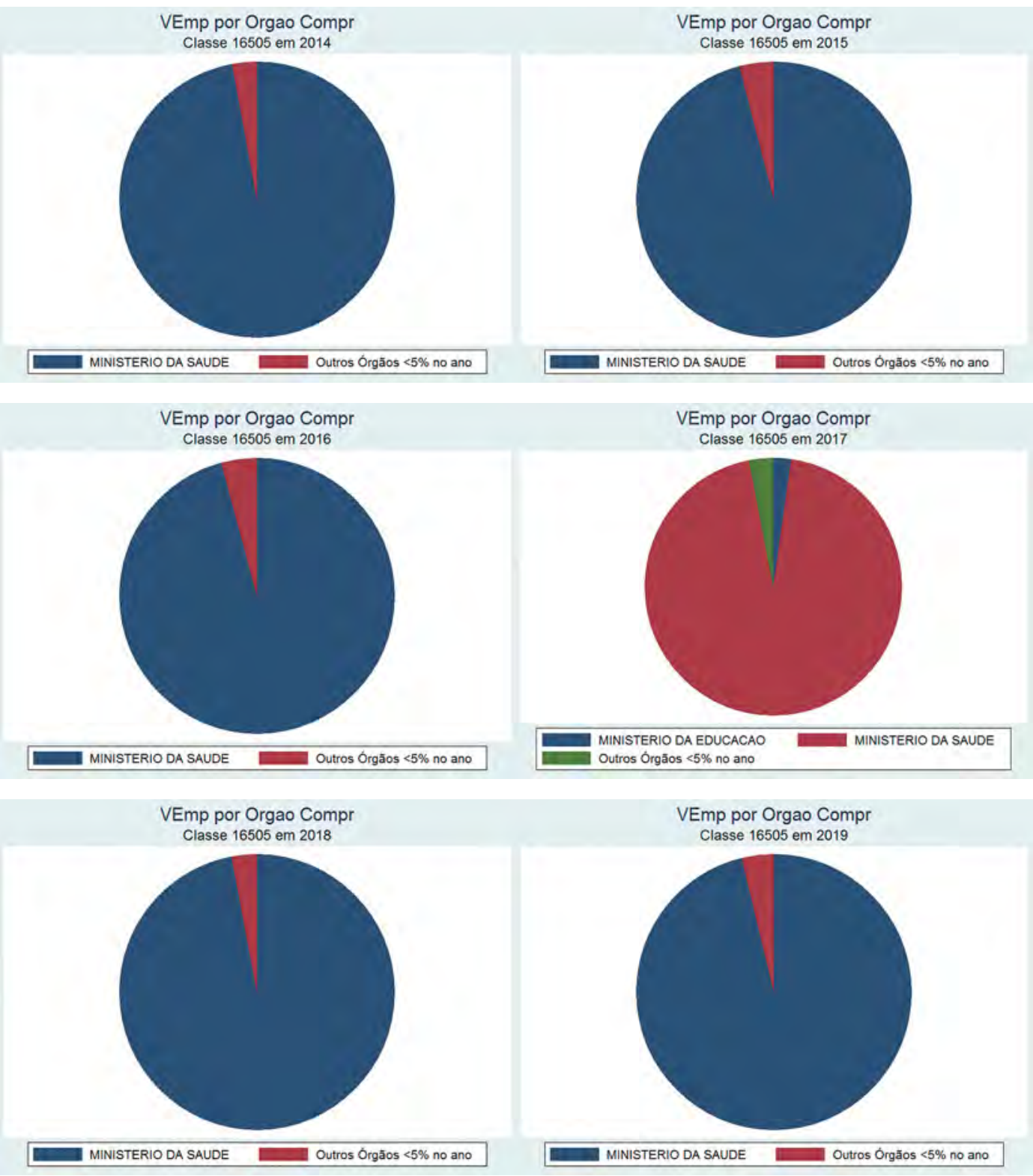

94 
Classe 16515 - Instrumentos, equipamentos e suprimentos médicos e cirúrgicos

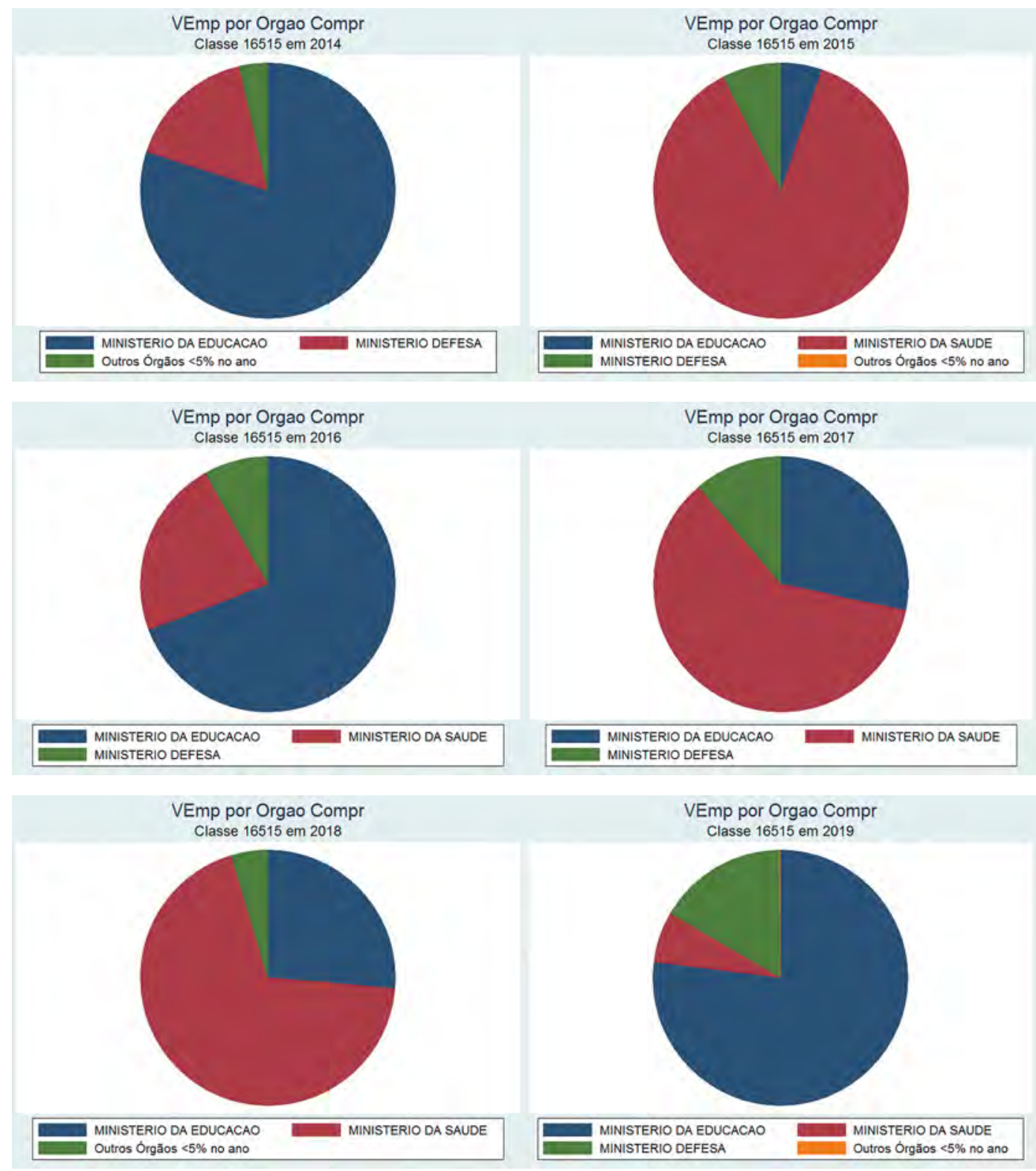


Classe 16532 - Vestuário hospitalar e cirúrgico e itens correlatos de finalidades especiais
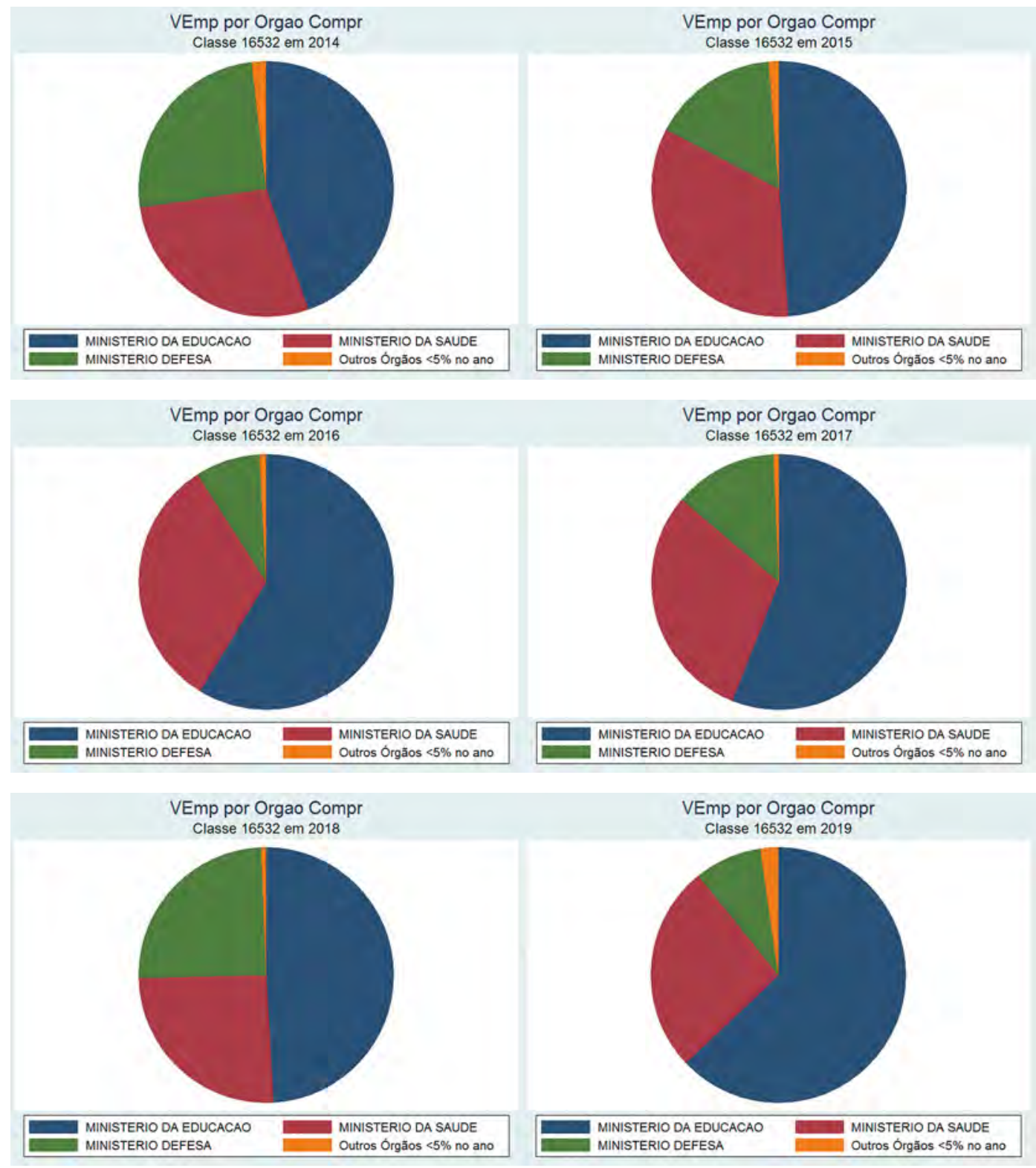
Texto para

Discussão

2575 Compras Públicas Centralizadas em Situações de Emergência e Calamidade Pública

Classe 16810 - Produtos químicos

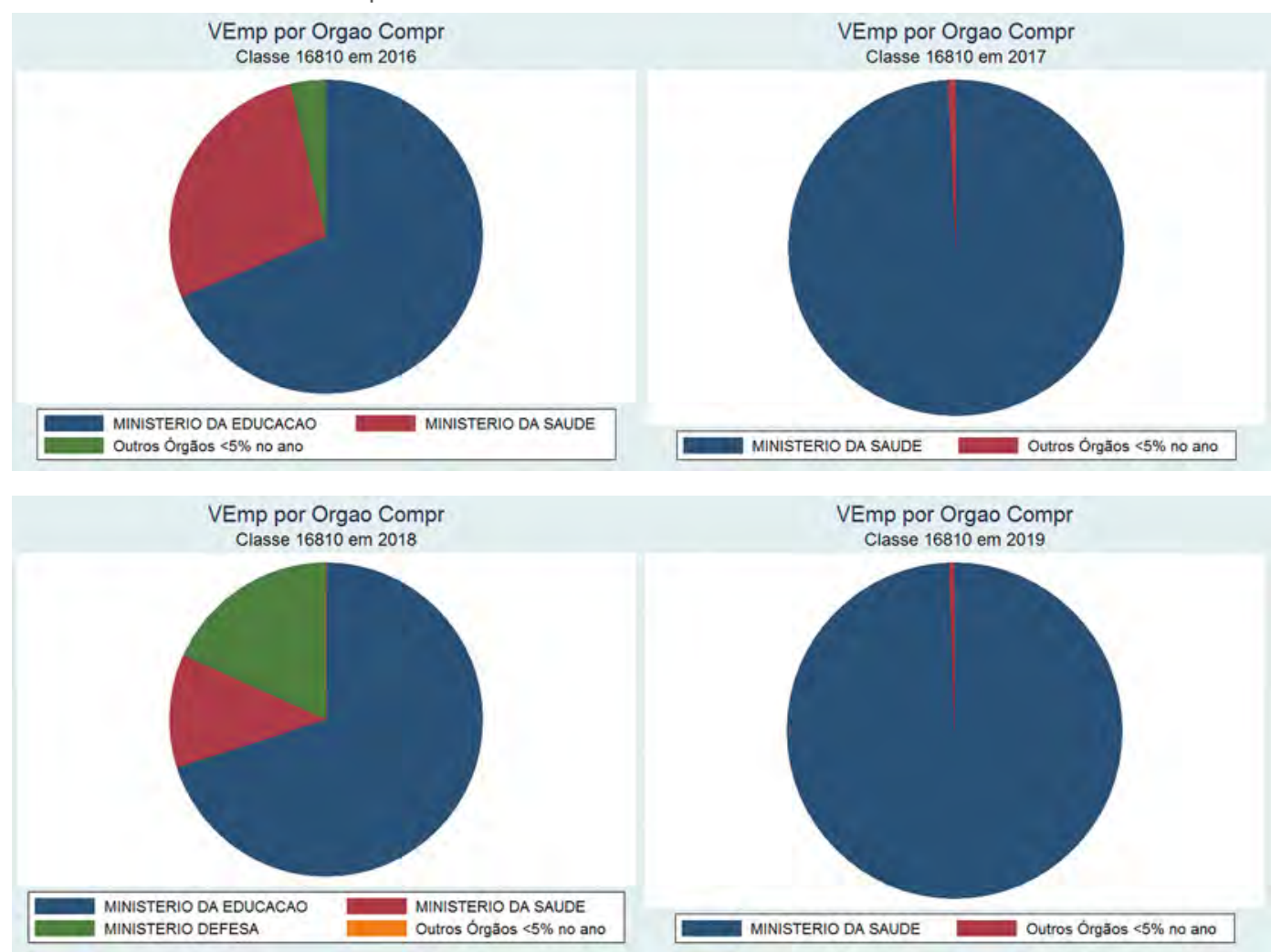


Classe 18105 - Sacos e bolsas

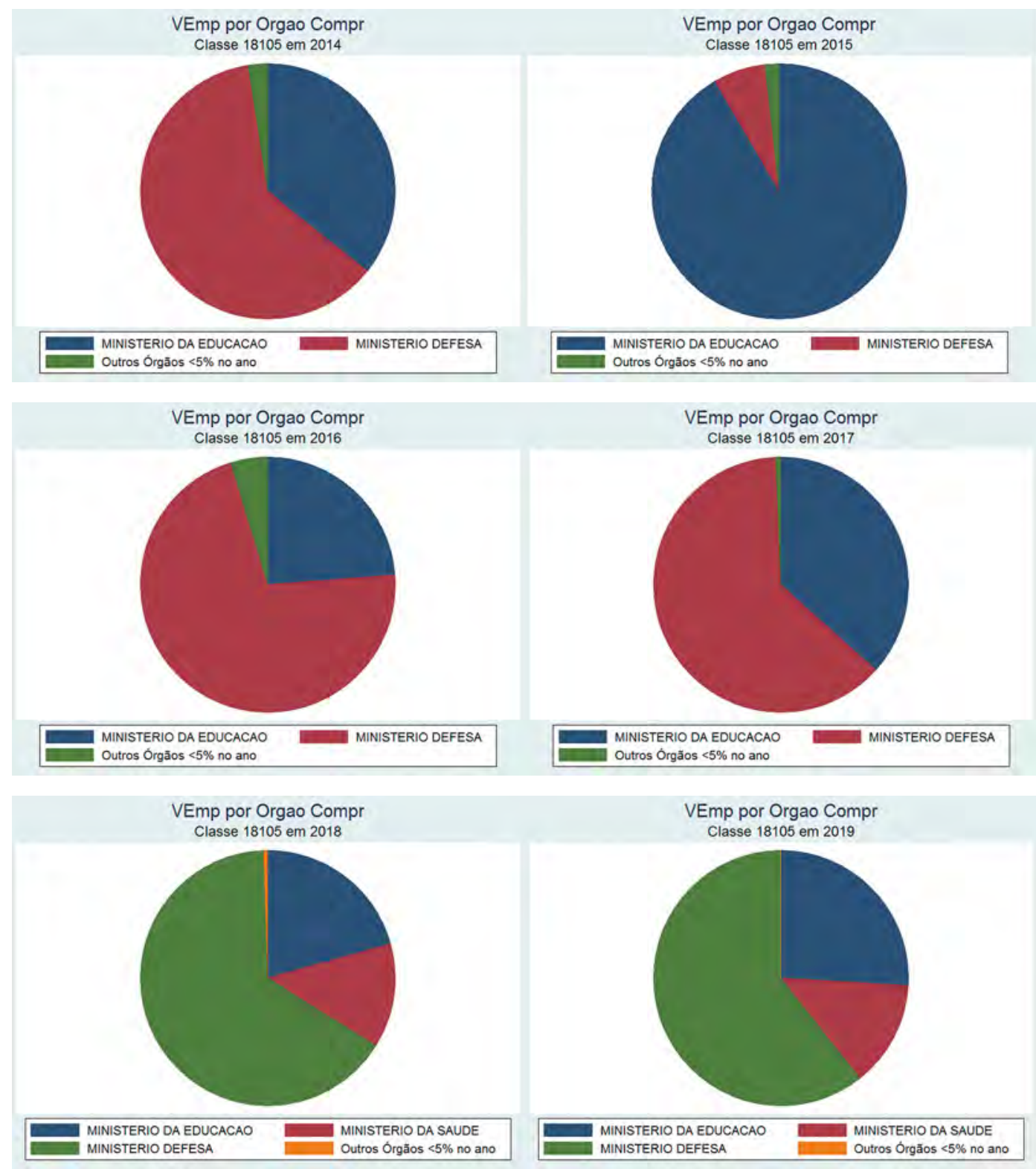


Texto para

Discussão

2575 Compras Públicas Centralizadas em Situações de Emergência e Calamidade Pública

Classe 18520 - Sabonetes, artigos para barbear e dentifrícios
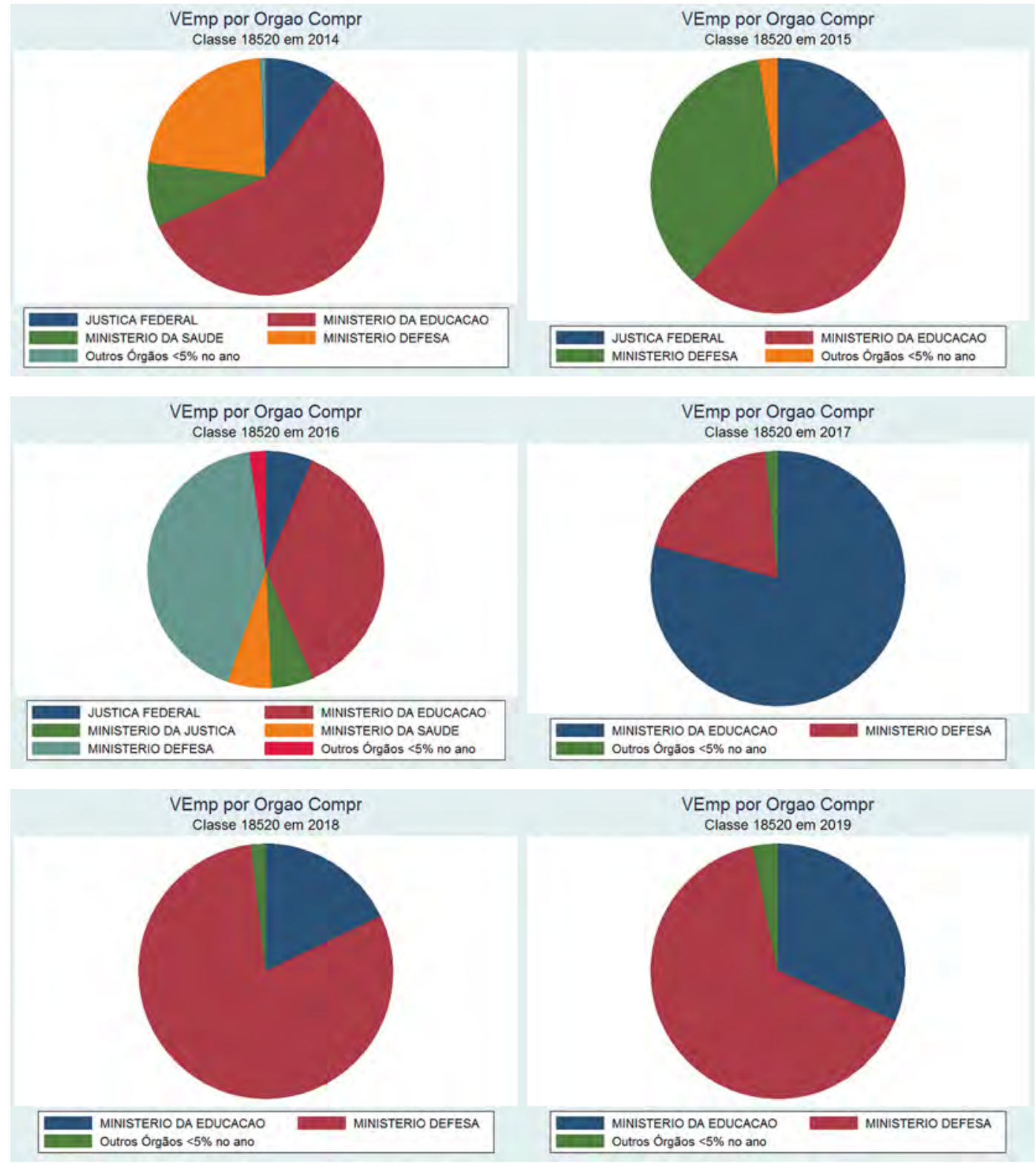
Classe 18540 - Artigos de papel para higiene
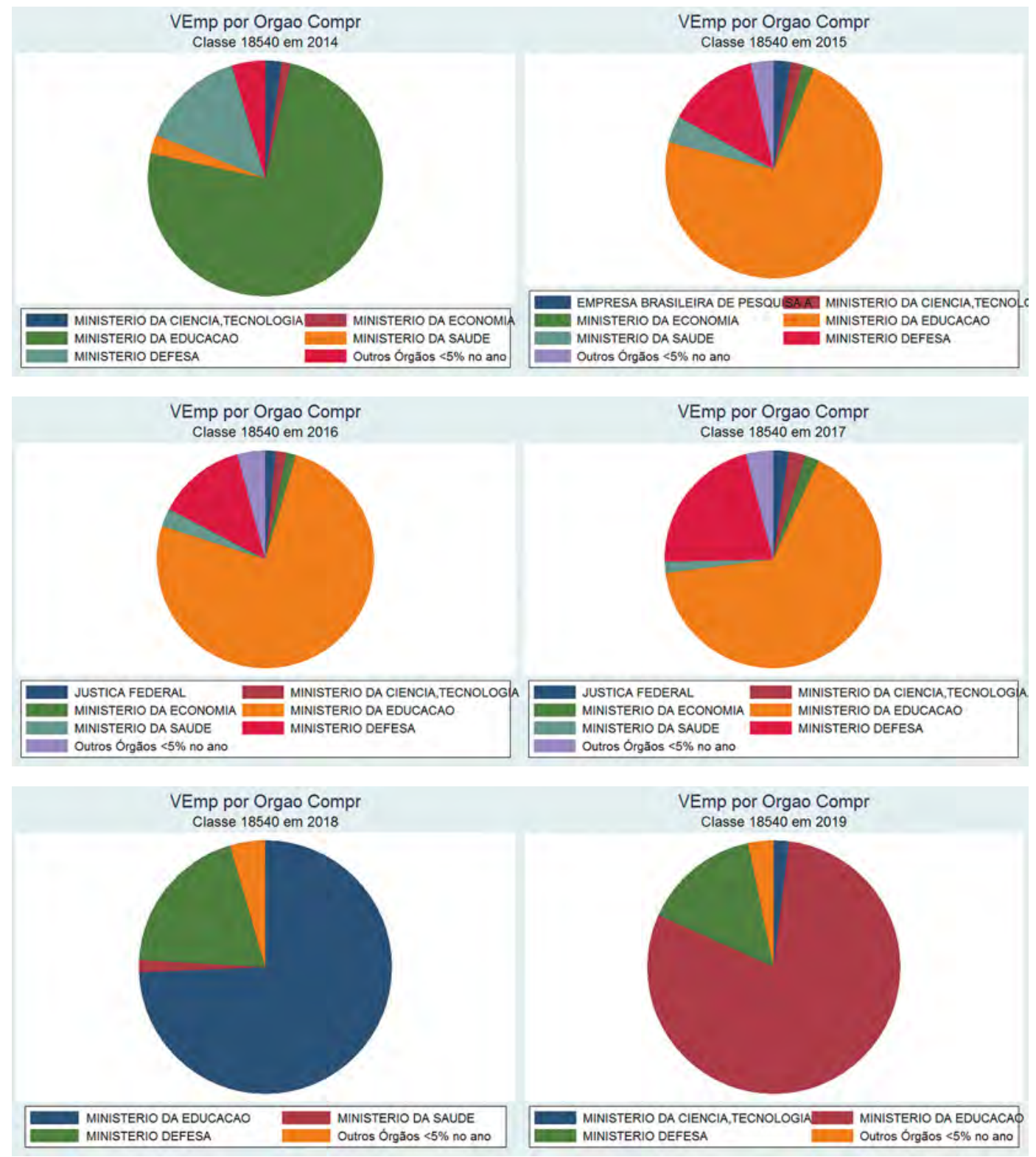
FIGURA A.3

Valor empenhado, por órgão responsável - participação no total anual, por classe

Classe 14240 - Equipamento para segurança e salvamento
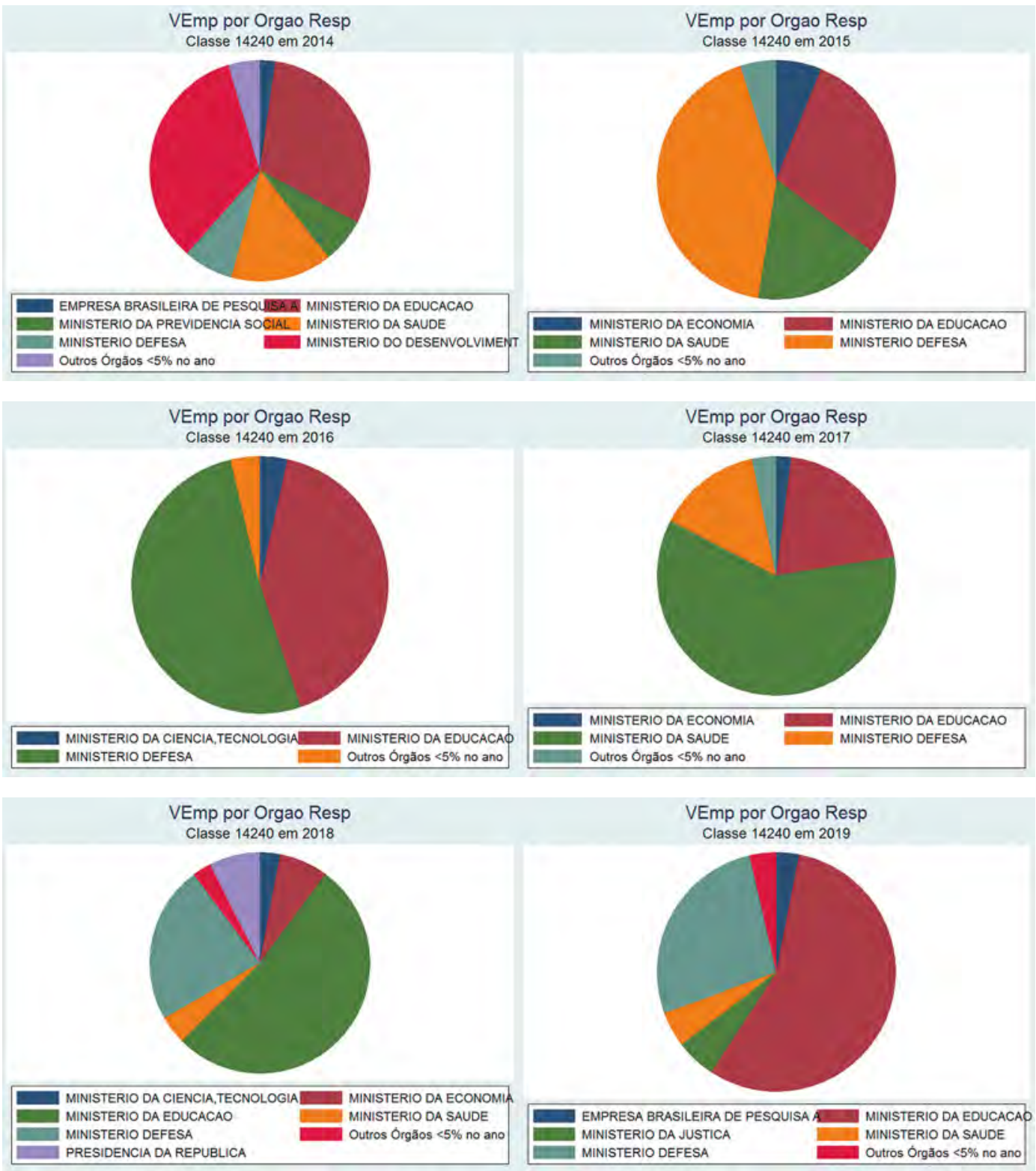
Classe 16505 - Drogas e medicamentos

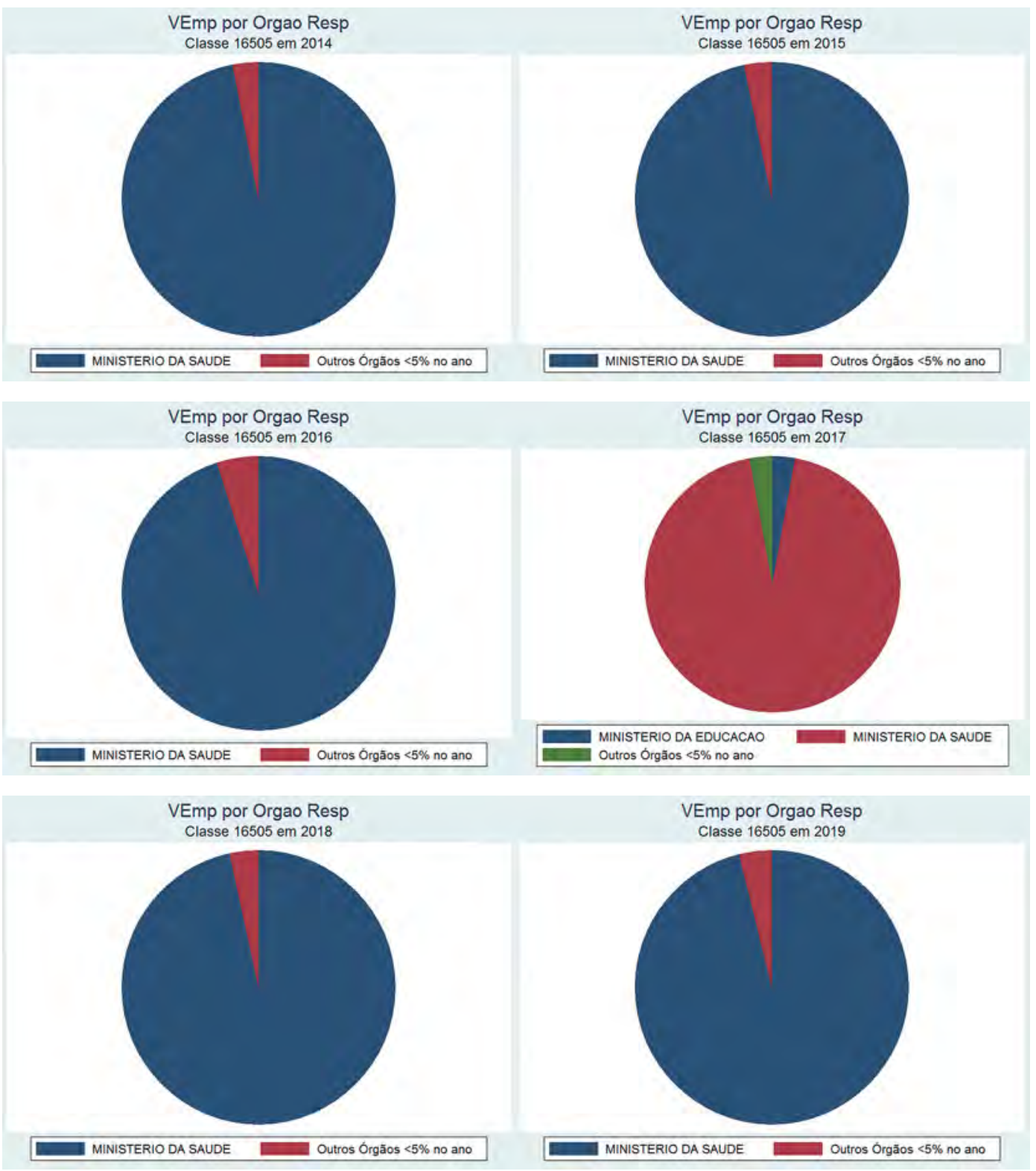


Classe 16515 - Instrumentos, equipamentos e suprimentos médicos e cirúrgicos

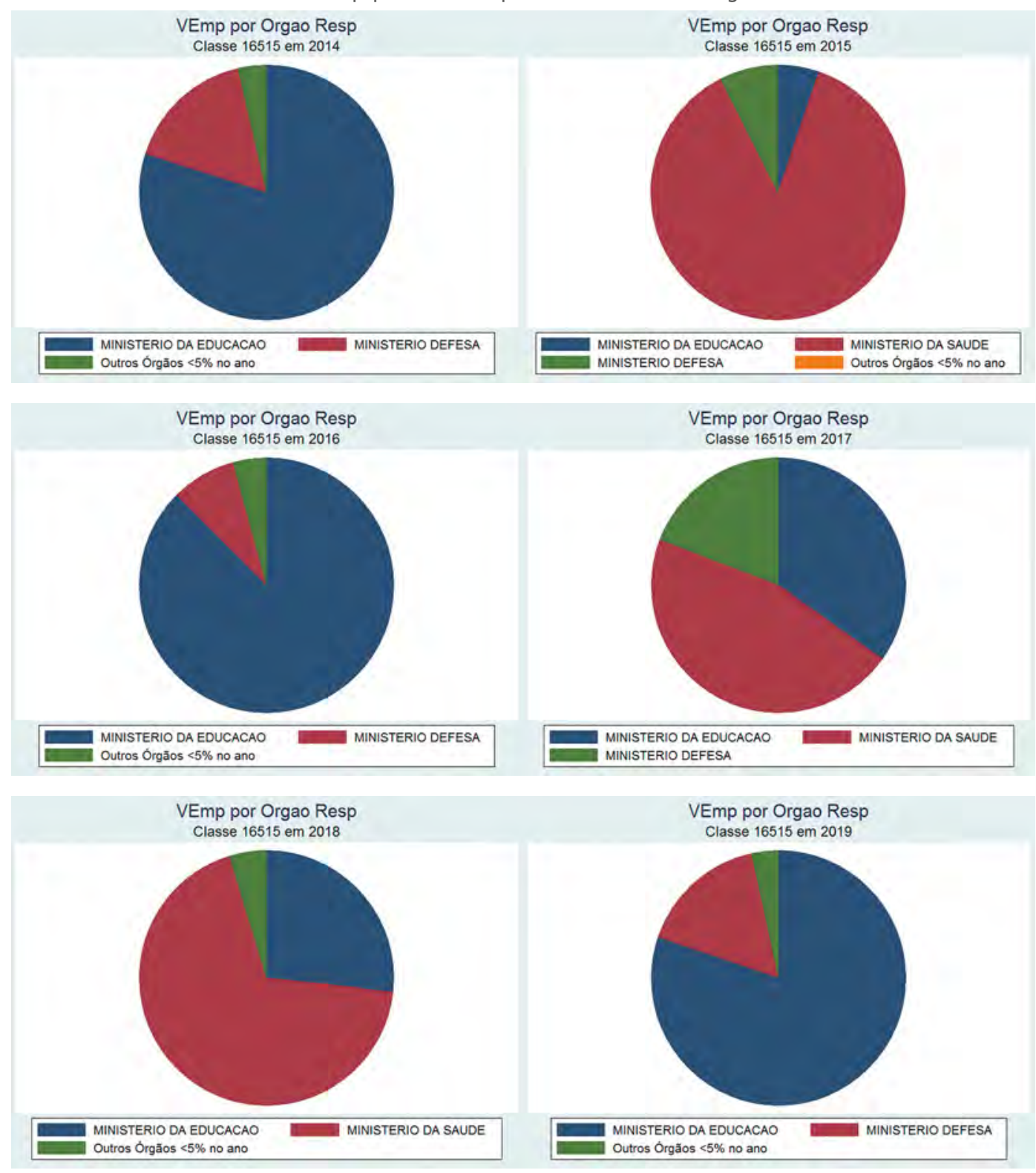


Classe 16532 - Vestuário hospitalar e cirúrgico e itens correlatos de finalidades especiais
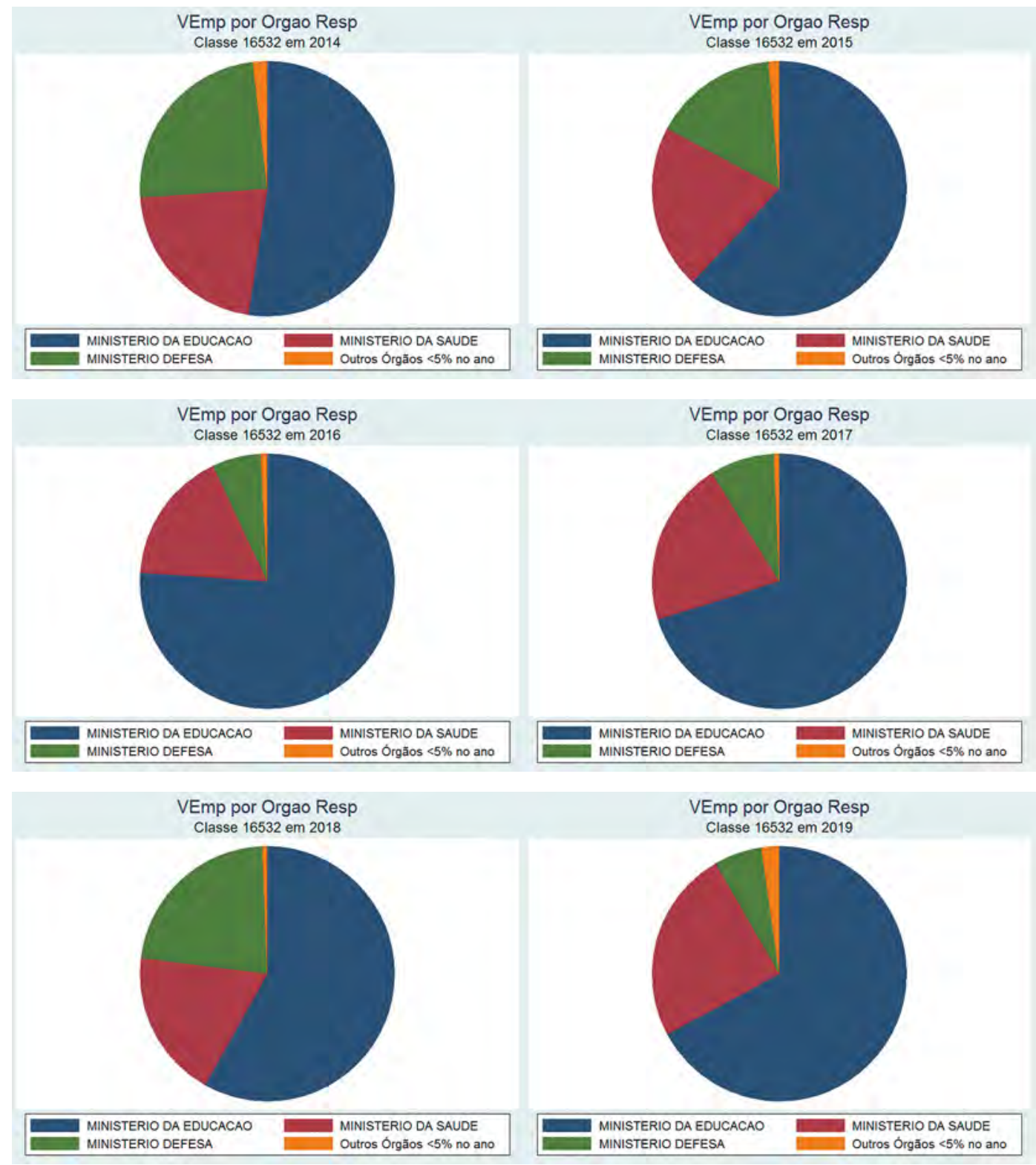
Texto para

Discussão

2575 Compras Públicas Centralizadas em Situações de Emergência e Calamidade Pública

Classe 16810 - Produtos químicos

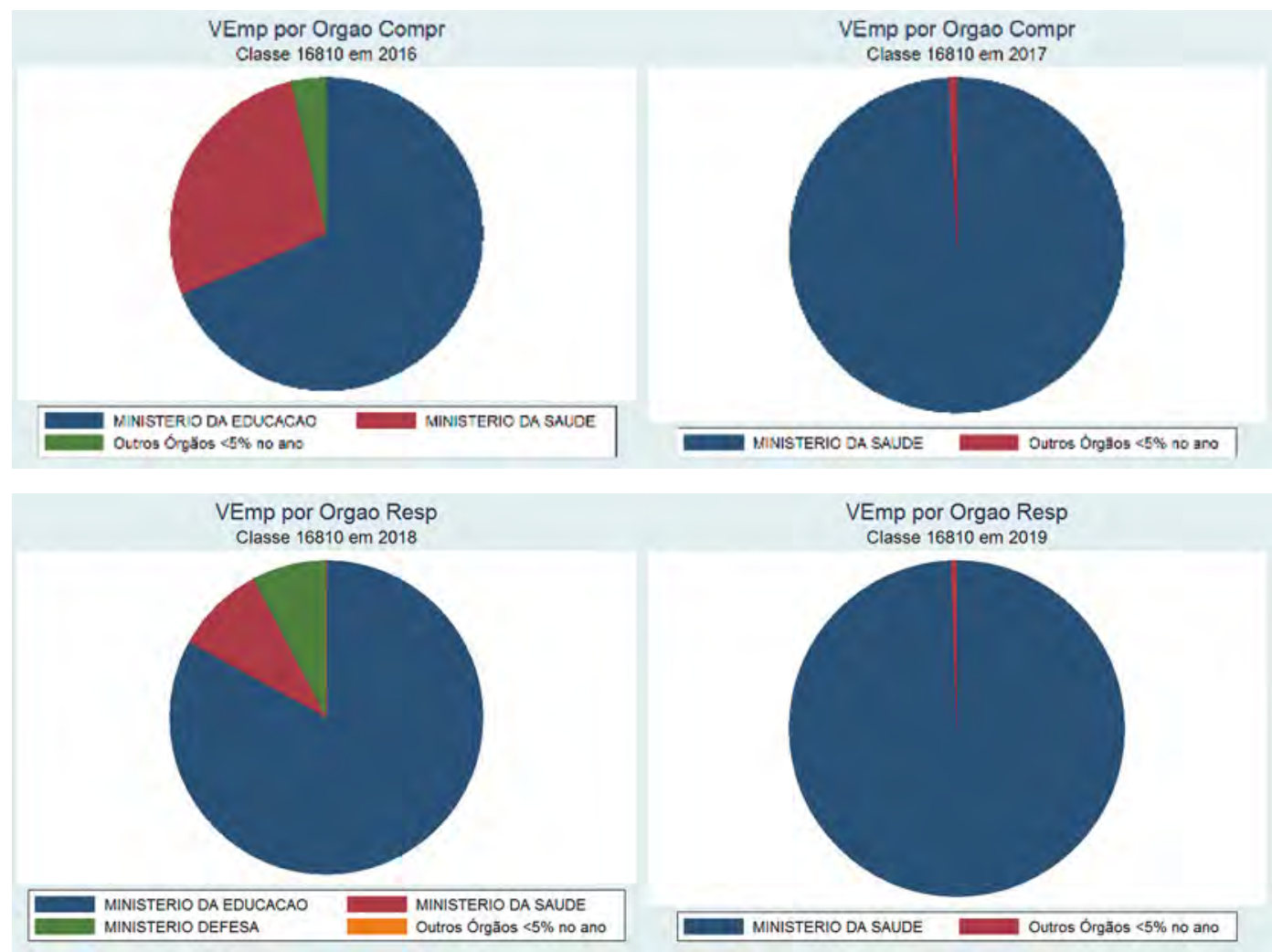


Classe 18105 - Sacos e bolsas

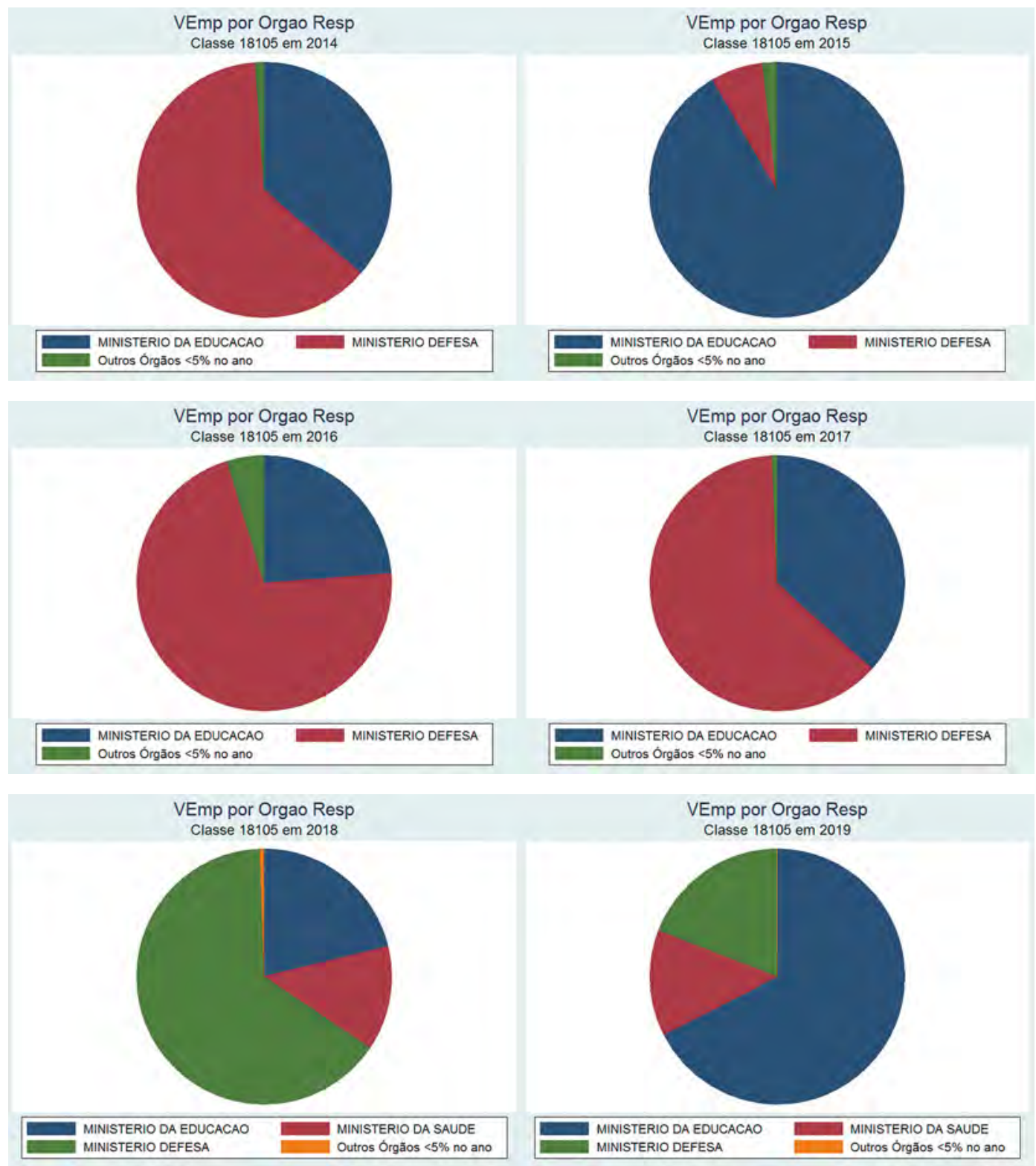


Texto para

Discussão

2575 Compras Públicas Centralizadas em Situações de Emergência e Calamidade Pública

Classe 18520 - Sabonetes, artigos para barbear e dentifrícios
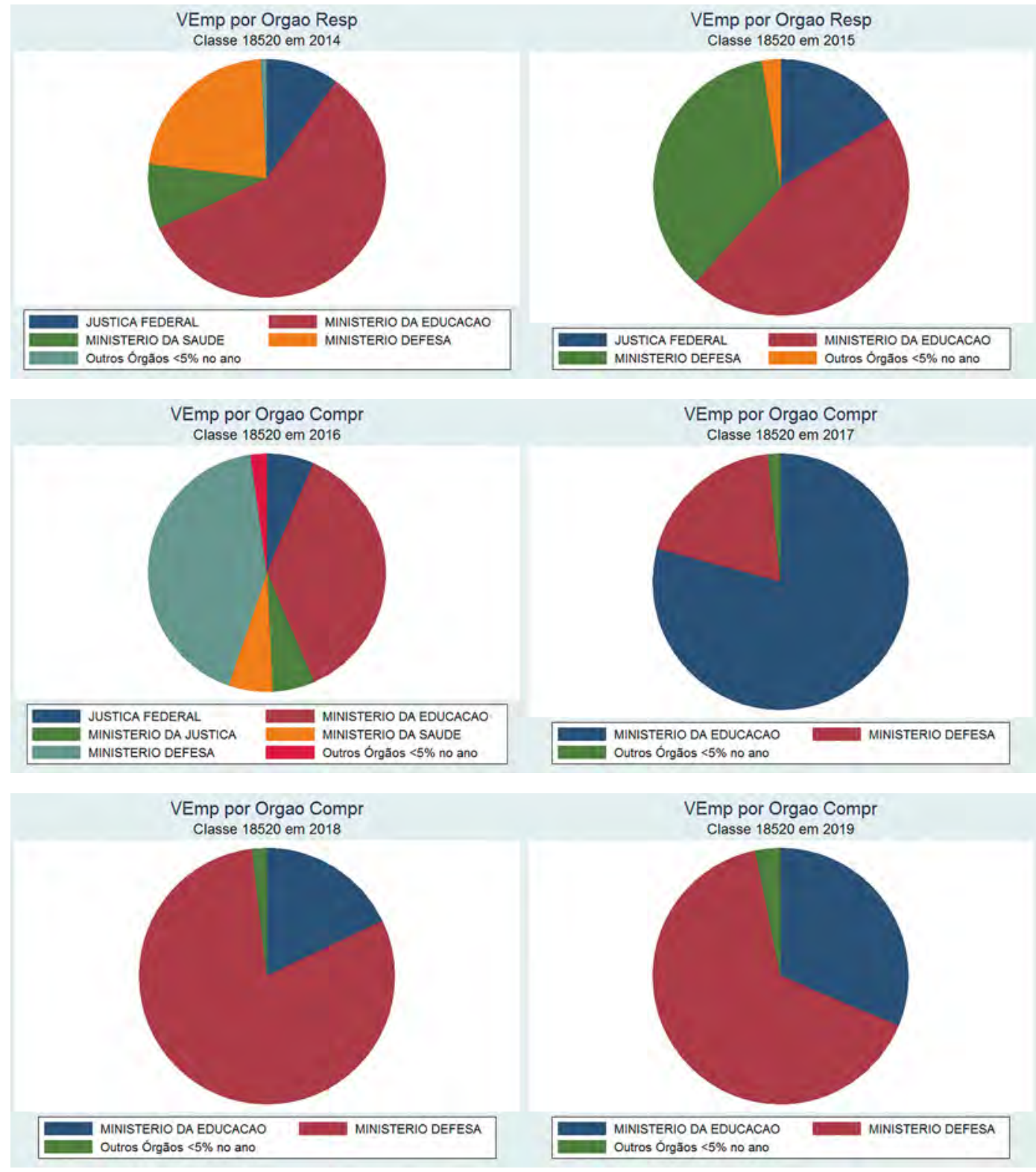
Classe 18540 - Artigos de papel para higiene
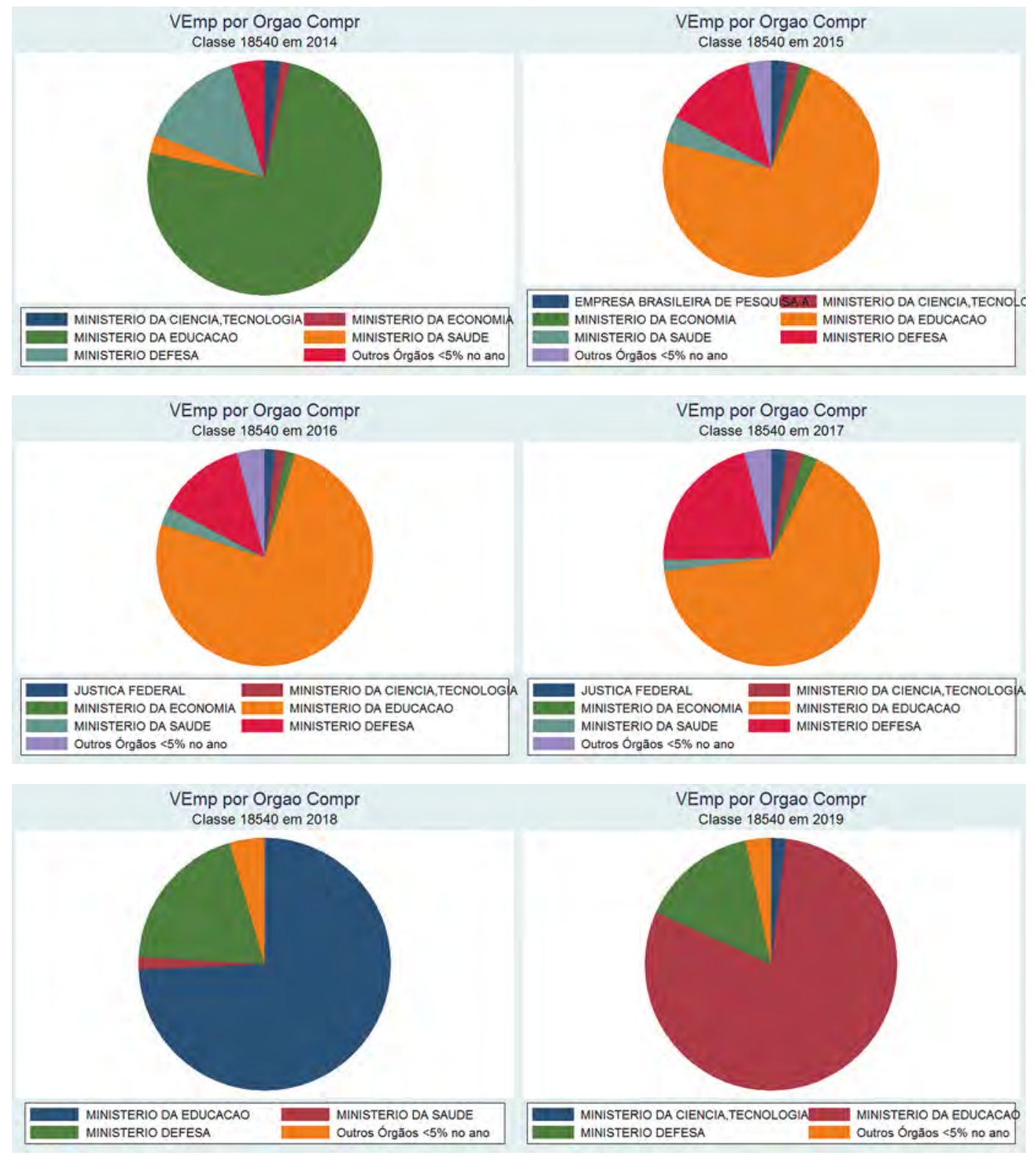
FIGURA A.4

VTH por órgão responsável - participação no total anual, por classe

Classe 14240 - Equipamento para segurança e salvamento
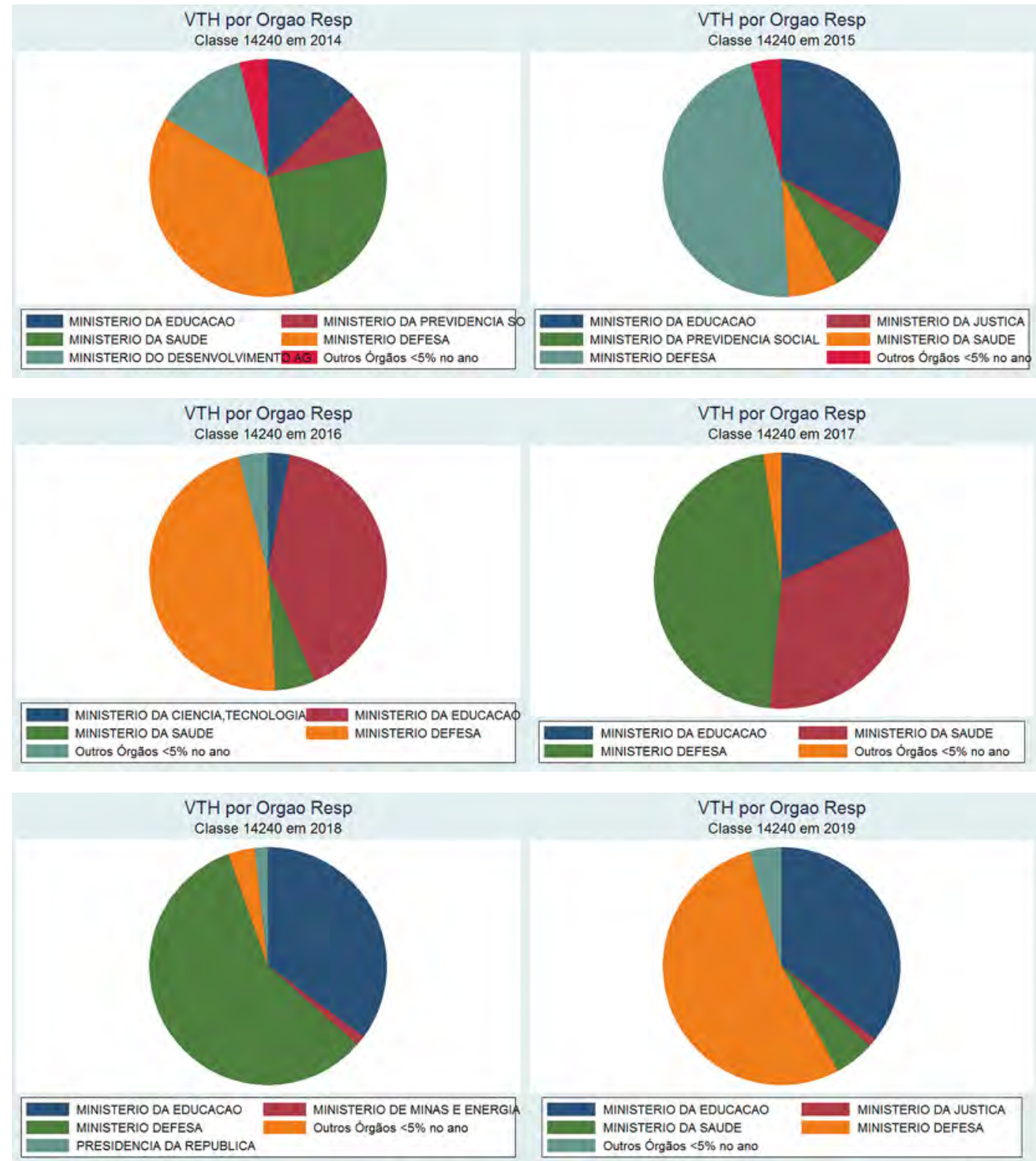
Classe 16505 - Drogas e medicamentos
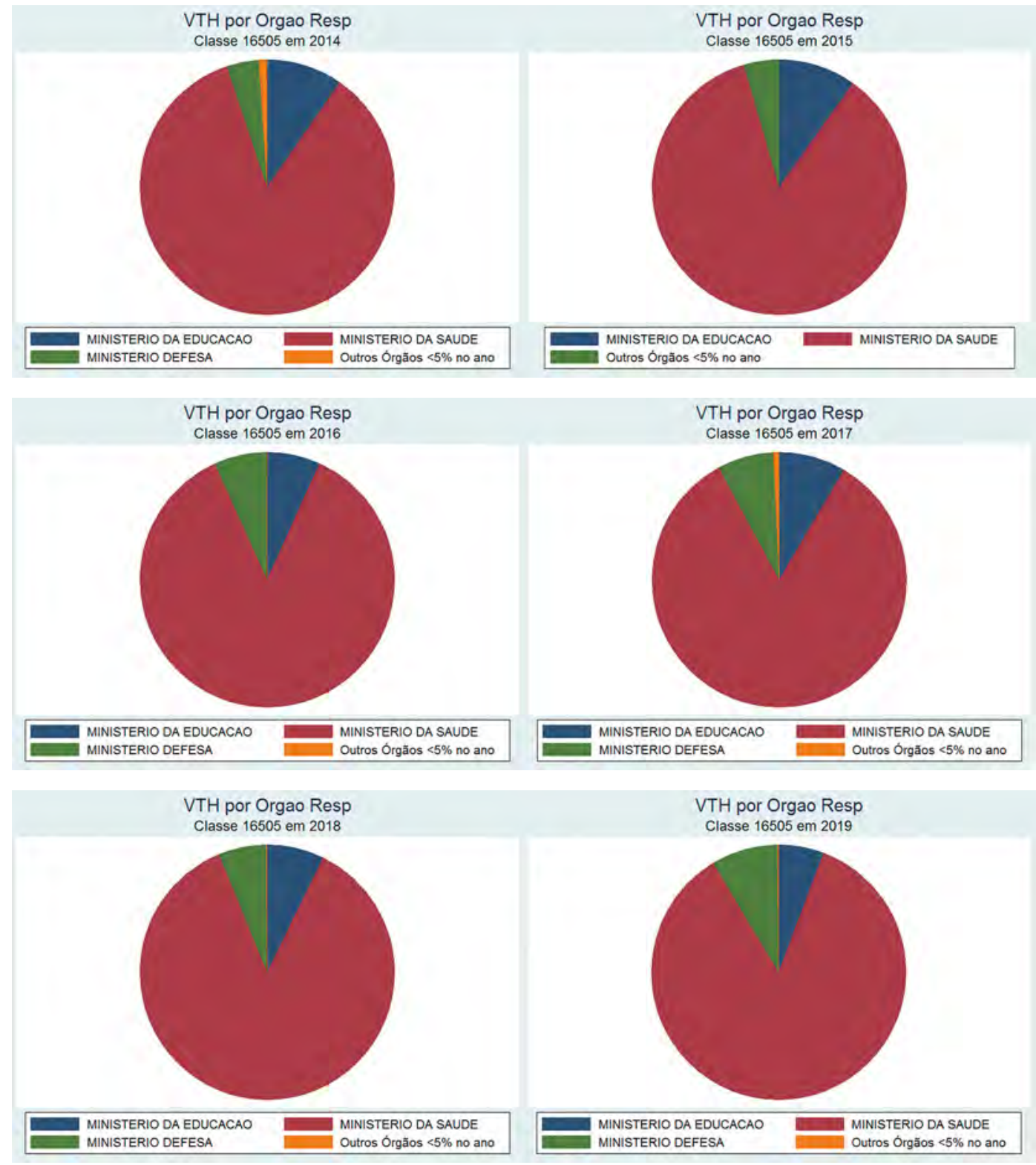
Texto para

Discussão

2575 Compras Públicas Centralizadas em Situações de Emergência e Calamidade Pública

Classe 16515 - Instrumentos, equipamentos e suprimentos médicos e cirúrgicos
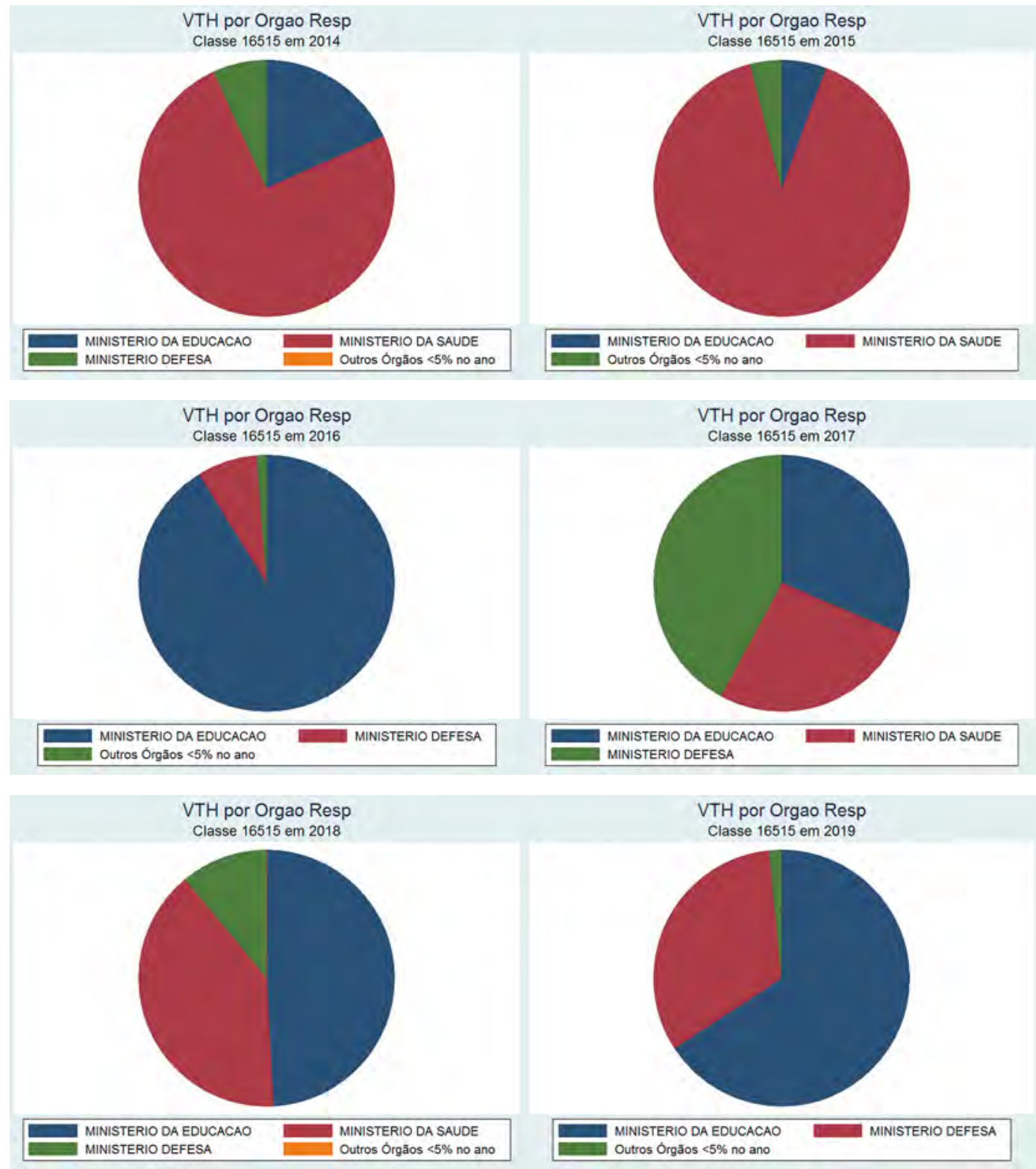
Classe 16532 - Vestuário hospitalar e cirúrgico e itens correlatos de finalidades especiais
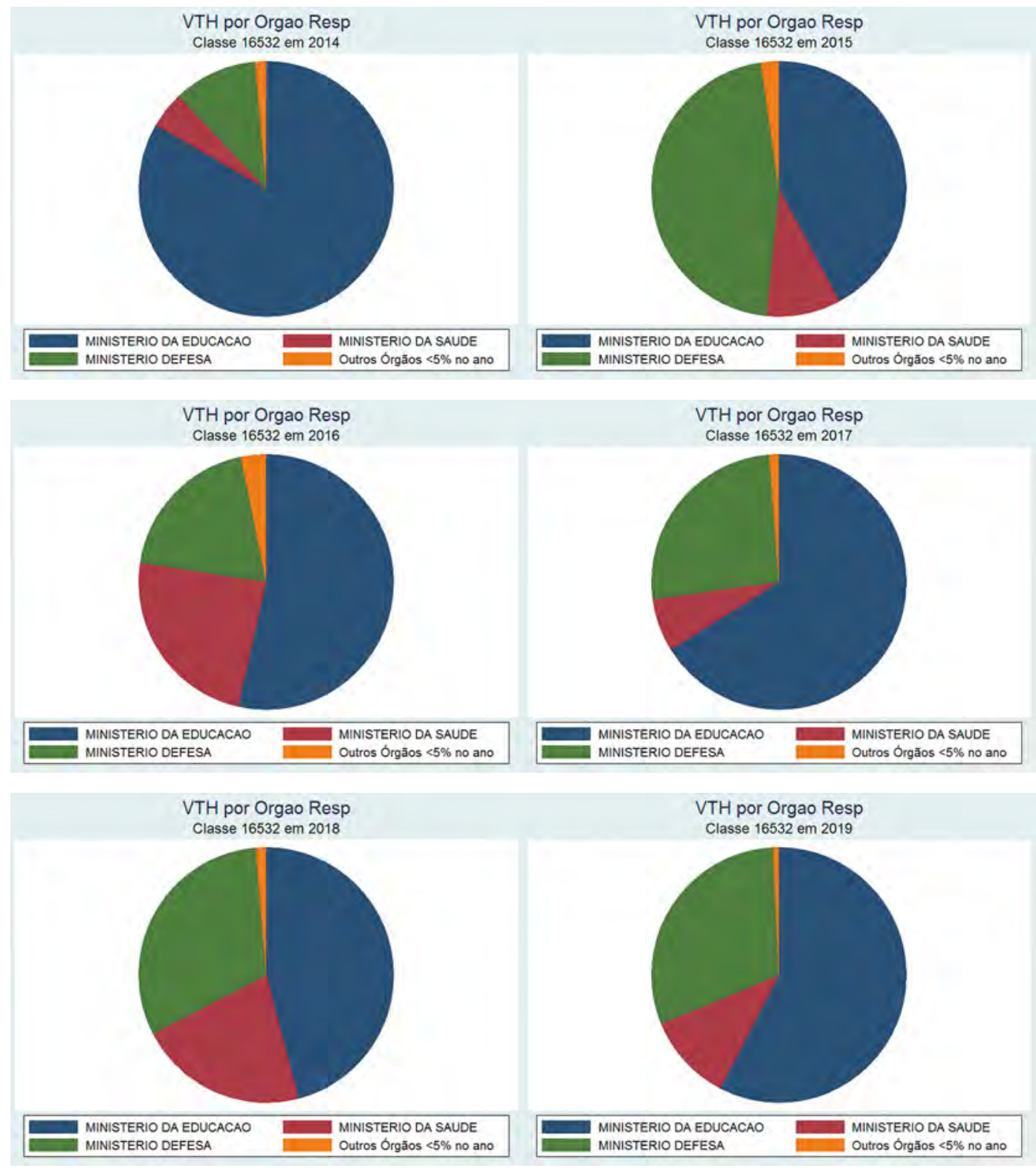
Texto para

Discussão

2575 Compras Públicas Centralizadas em Situações de Emergência e Calamidade Pública

Classe 16810 - Produtos químicos

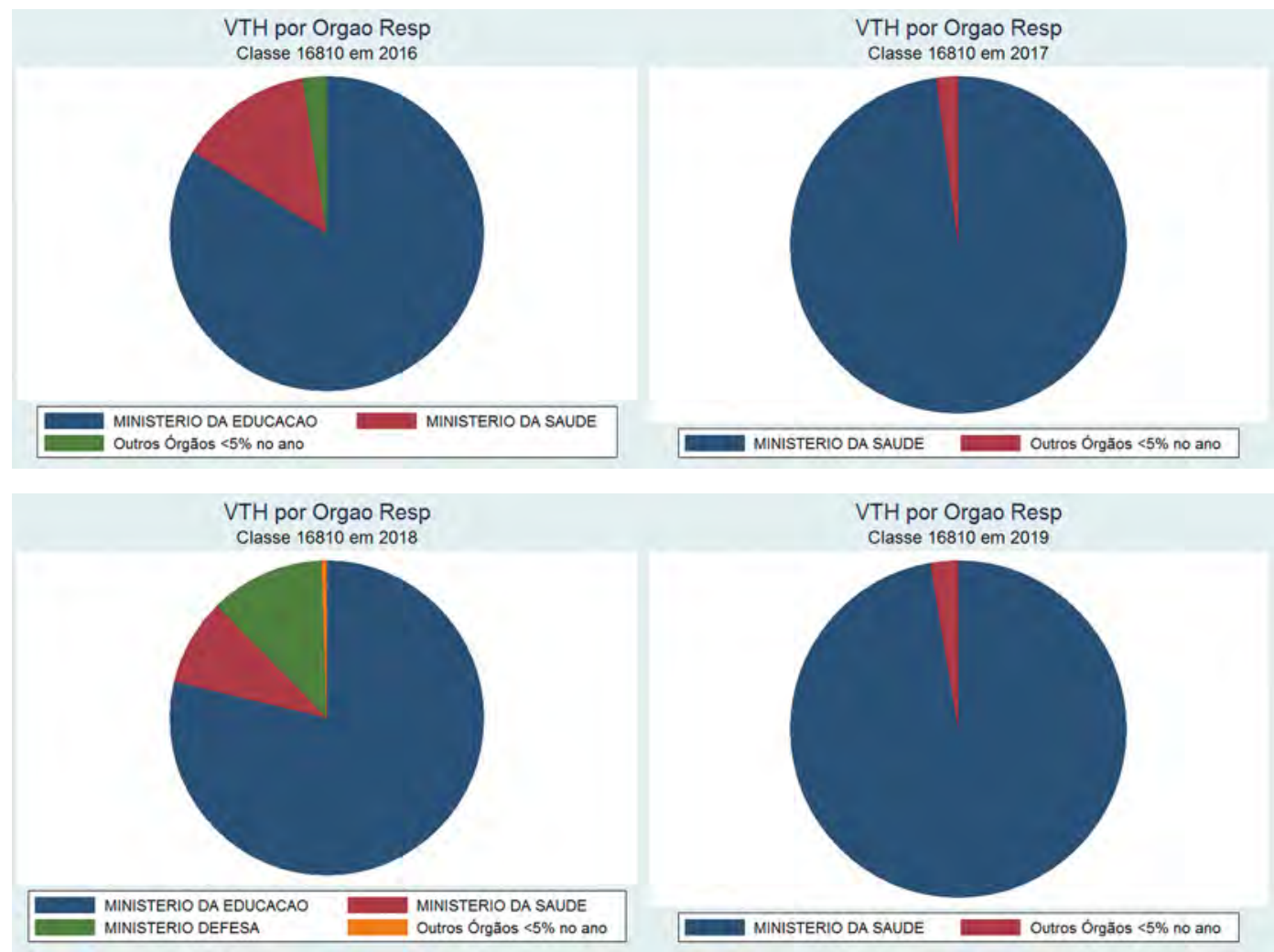


Classe 18520 - Sabonetes, artigos para barbear e dentifrícios
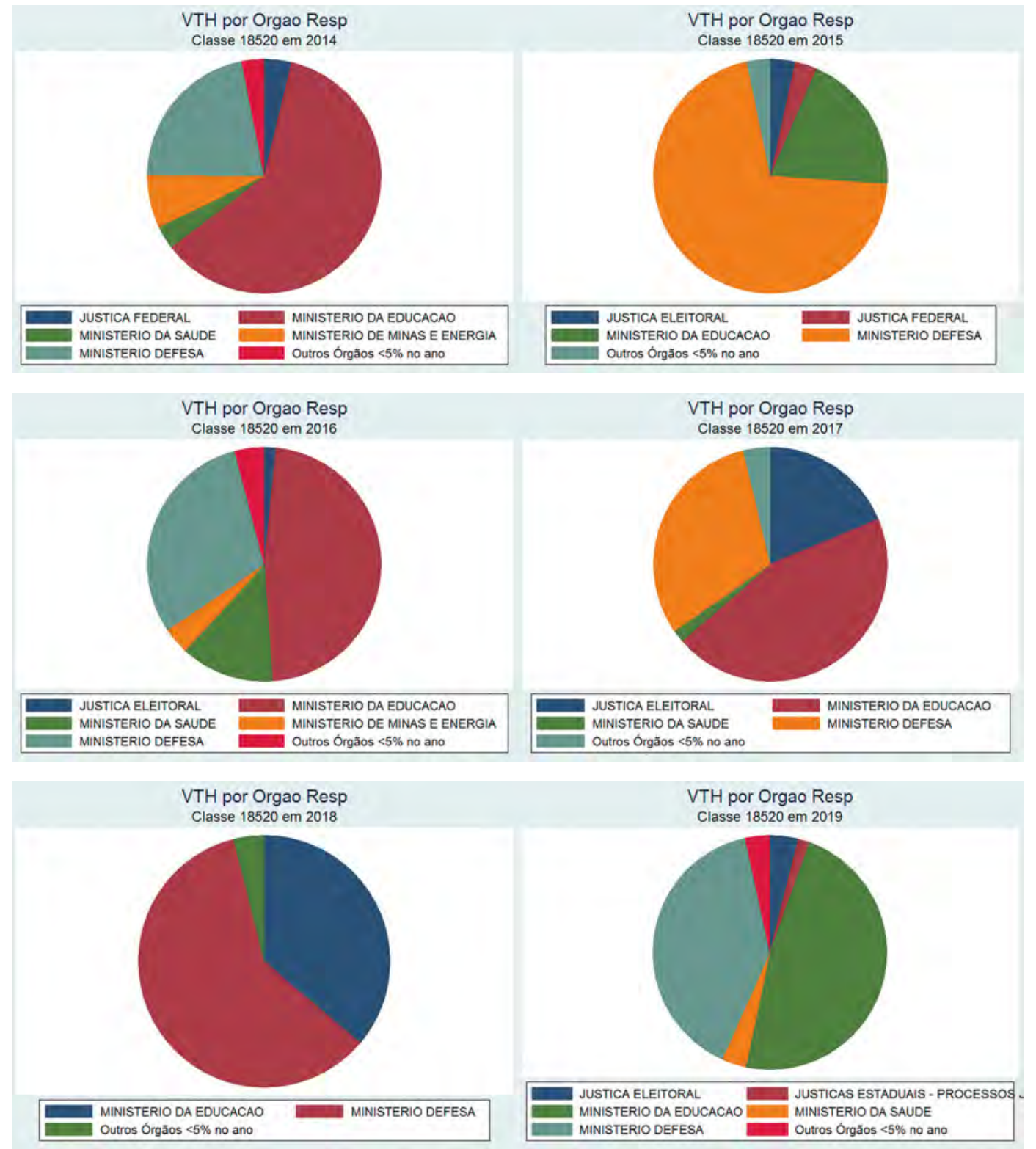
Texto para

Discussão

2575 Compras Públicas Centralizadas em Situações de Emergência e Calamidade Pública

Classe 18540 - Artigos de papel para higiene

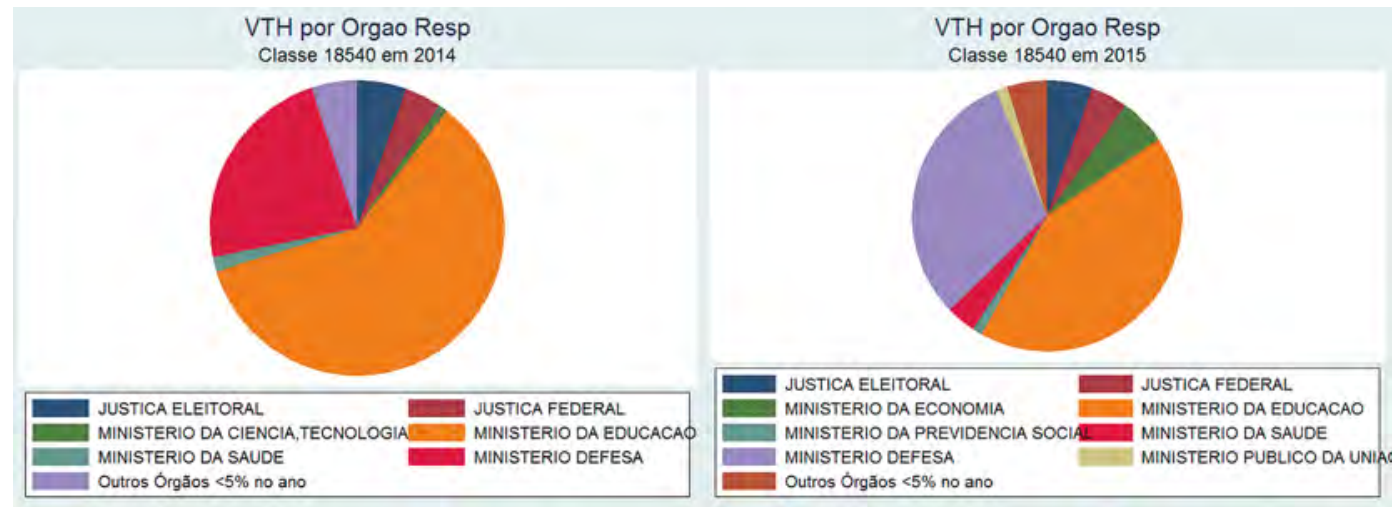
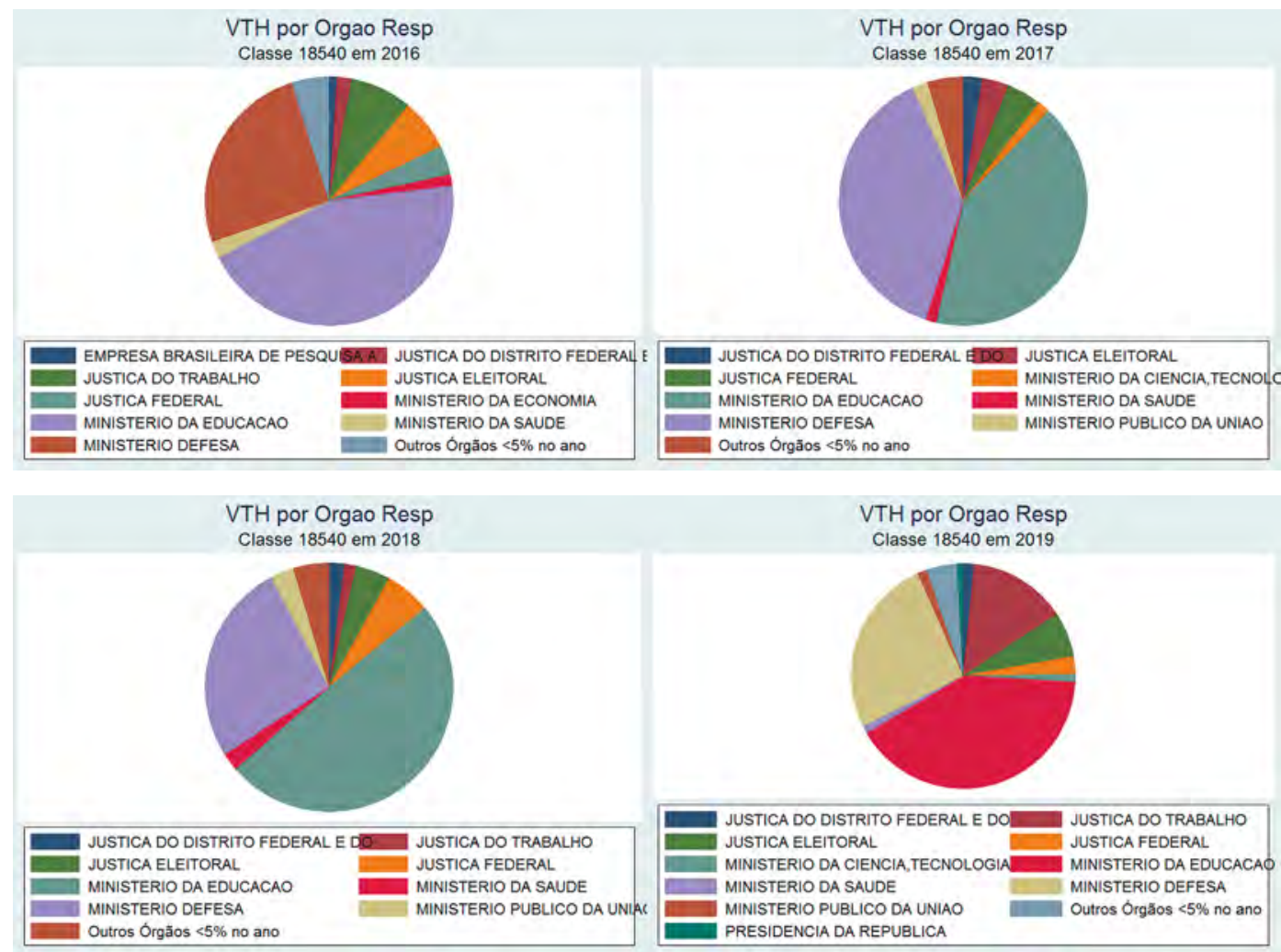
FIGURA A.5

Distribuição acumulada das quantidades de itens de compras conjuntas por unidade responsável pela compra, ano e classe ou segmento (2014-2019)

Classe 14240 - Equipamento para segurança e salvamento

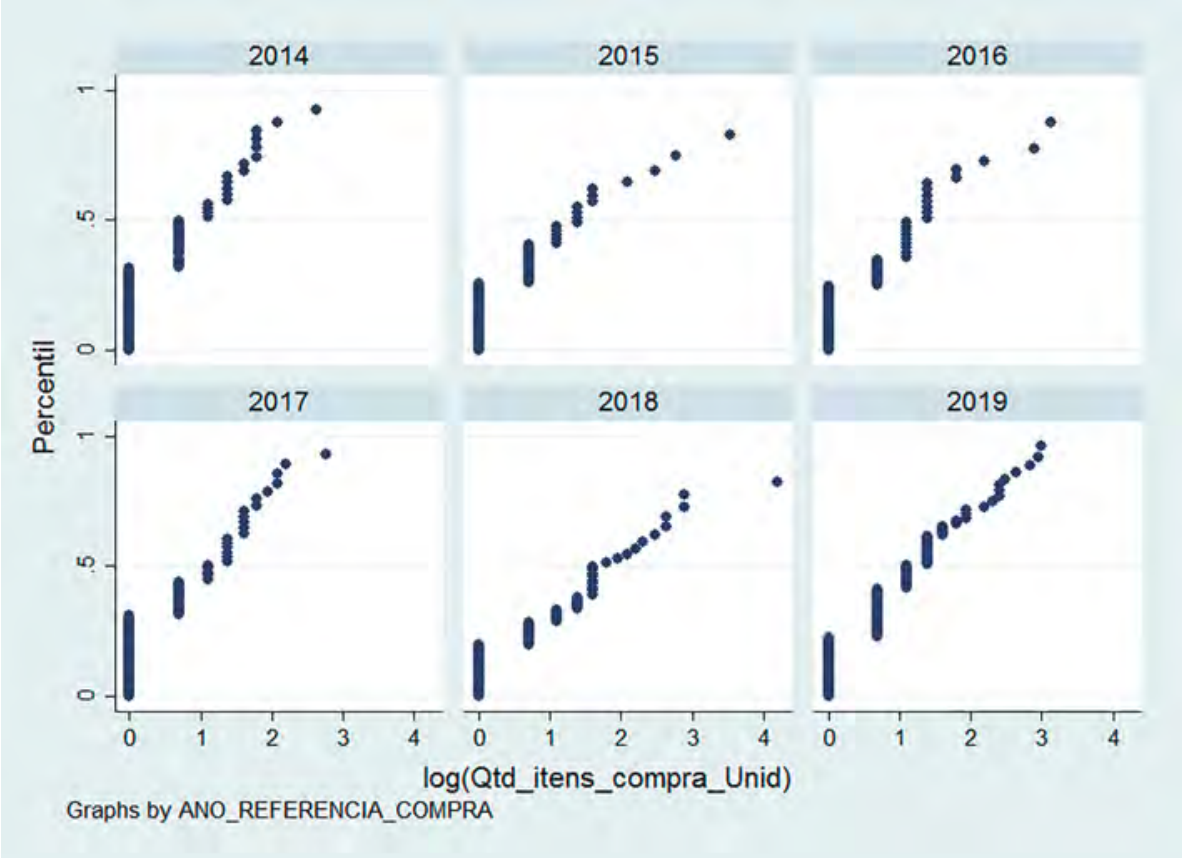

Classe 16505 - Drogas e medicamentos

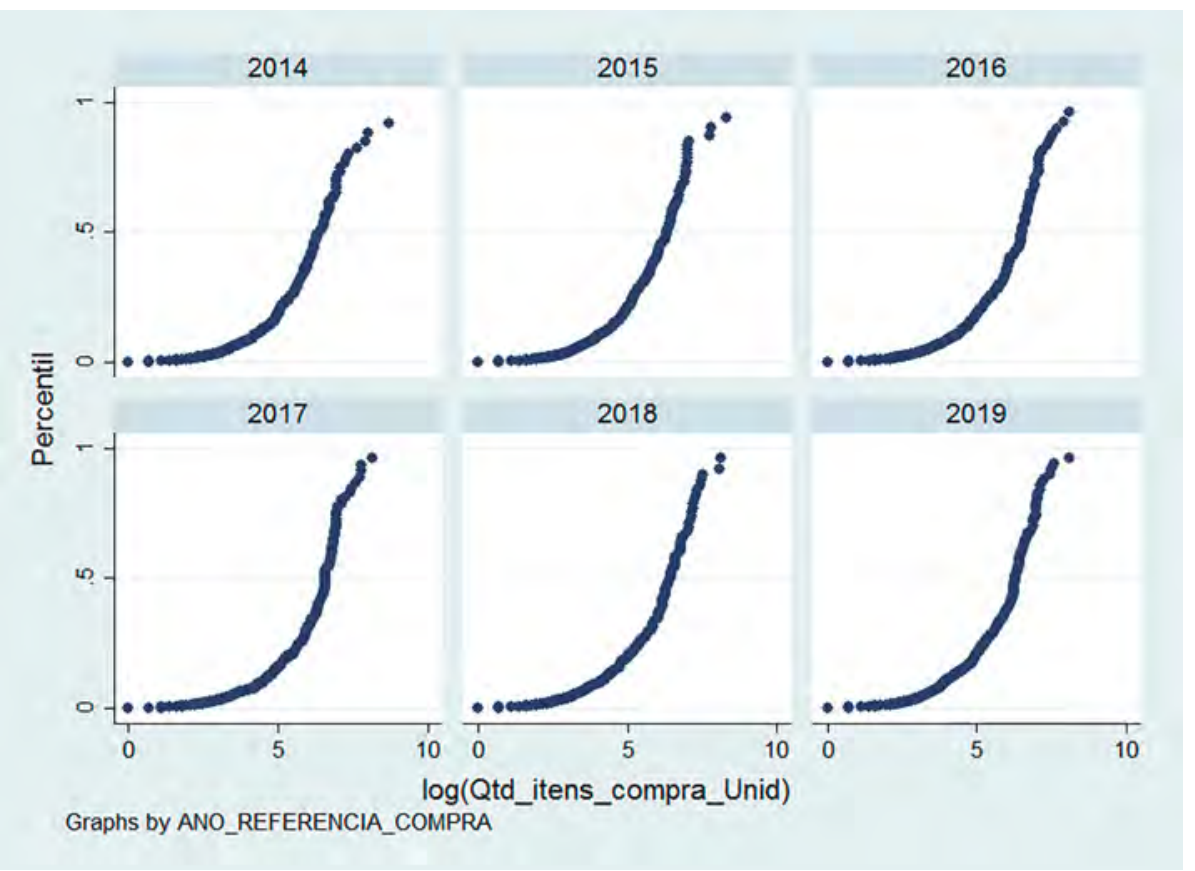


Classe 16515 - Instrumentos, equipamentos e suprimentos médicos e cirúrgicos

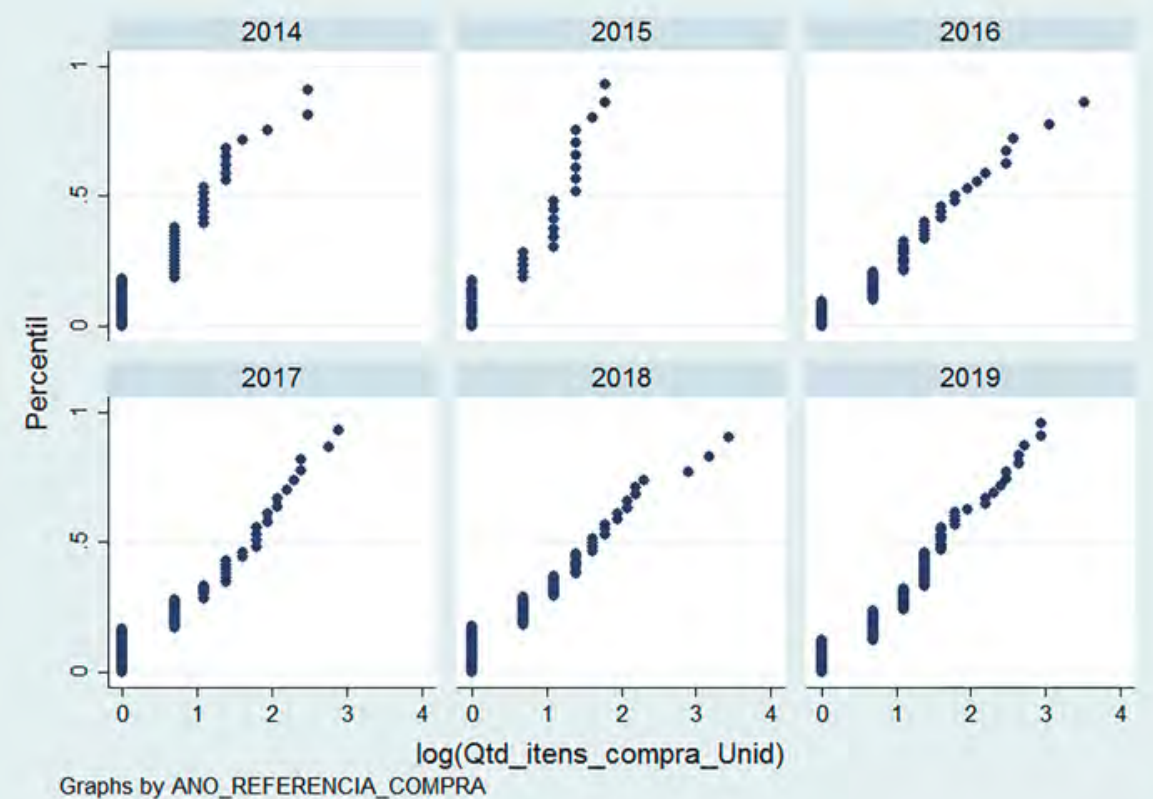

Classe 16532 - Vestuário hospitalar e cirúrgico e itens correlatos de finalidades especiais

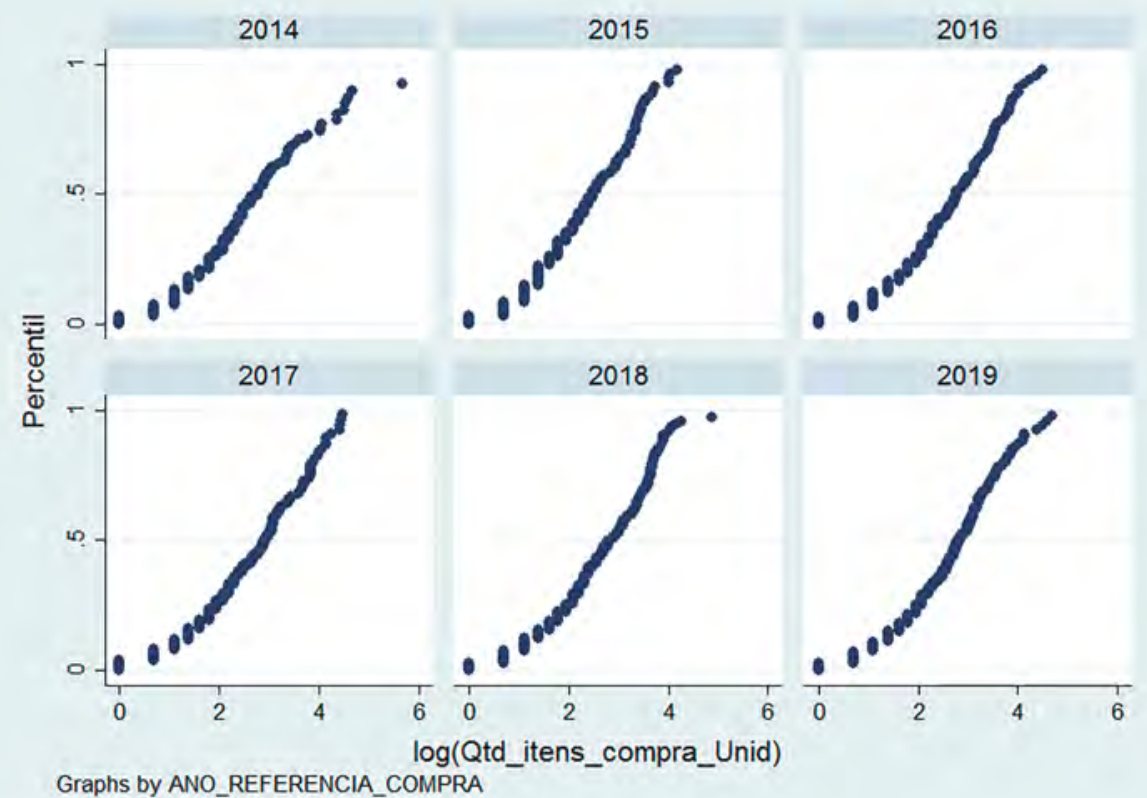


Classe 16810 - Produtos químicos

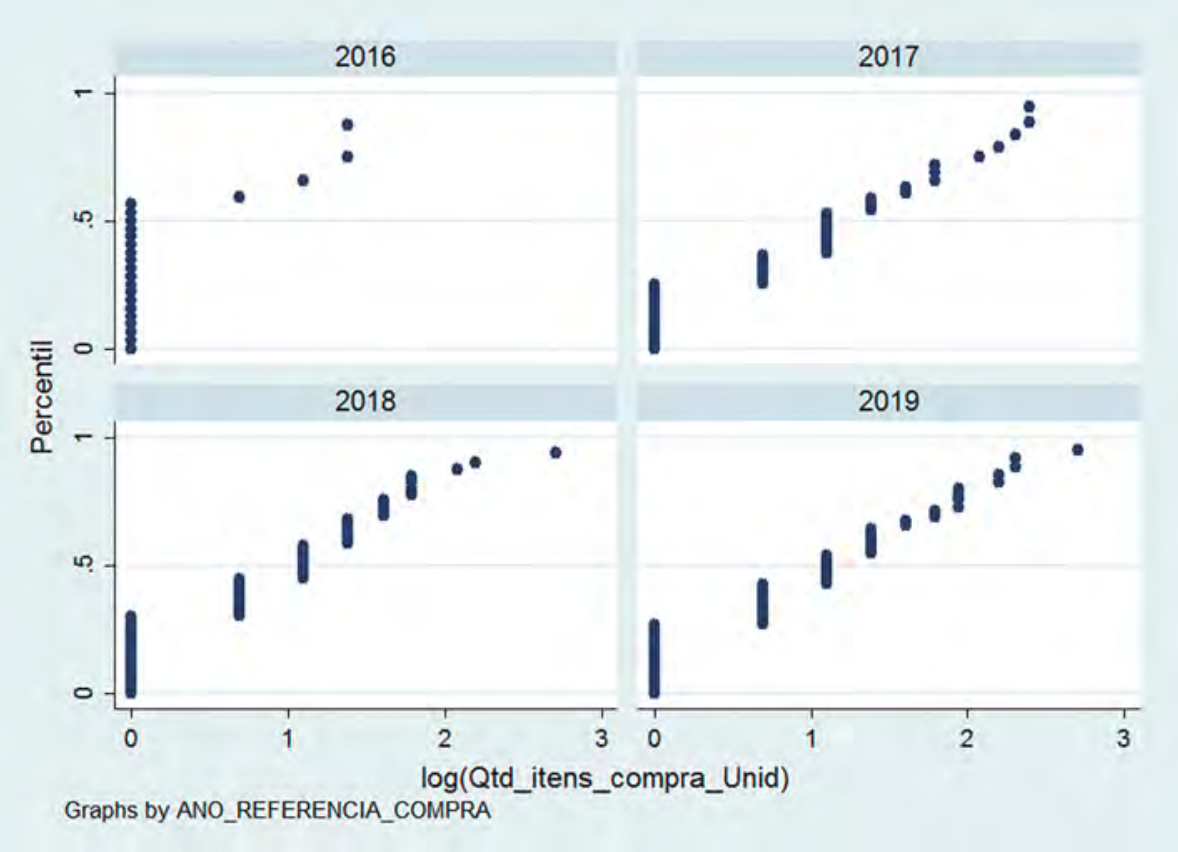

Classe 18105 - Sacos e bolsas

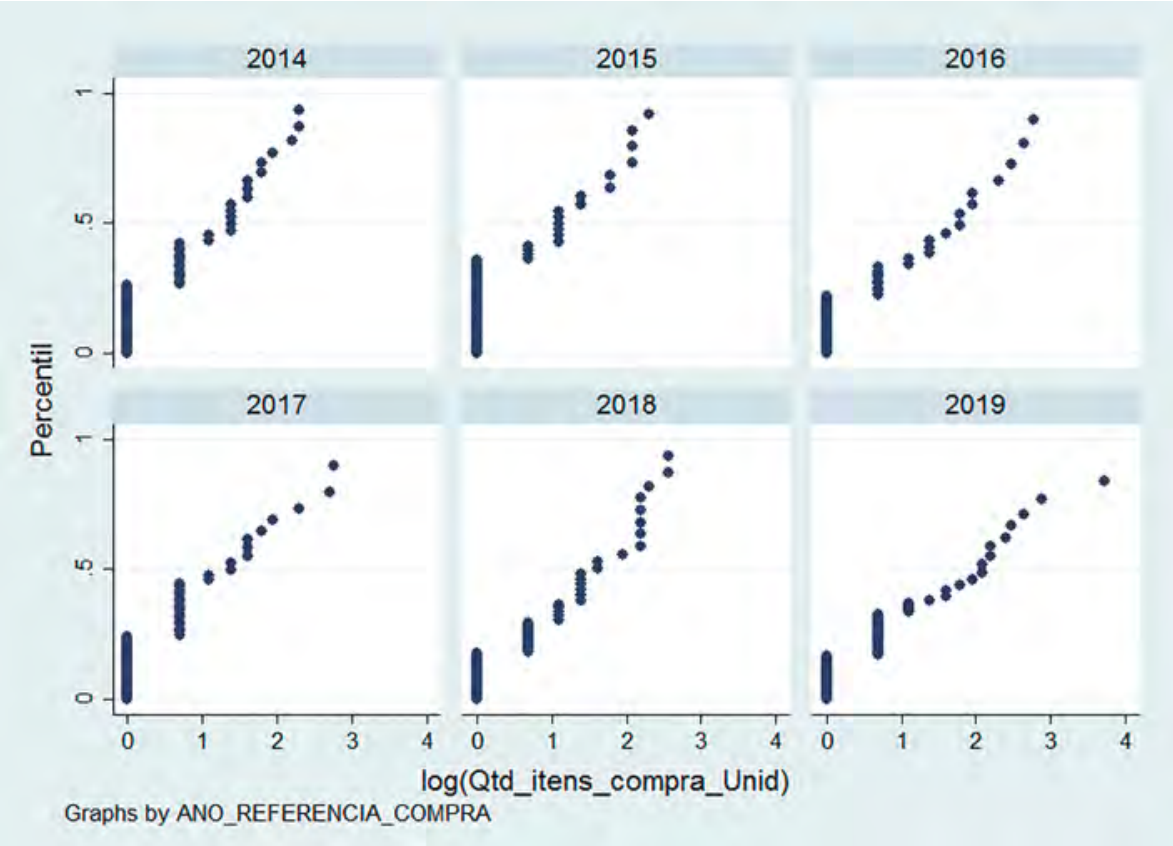


Classe 18520 - Sabonetes, artigos para barbear e dentifrícios

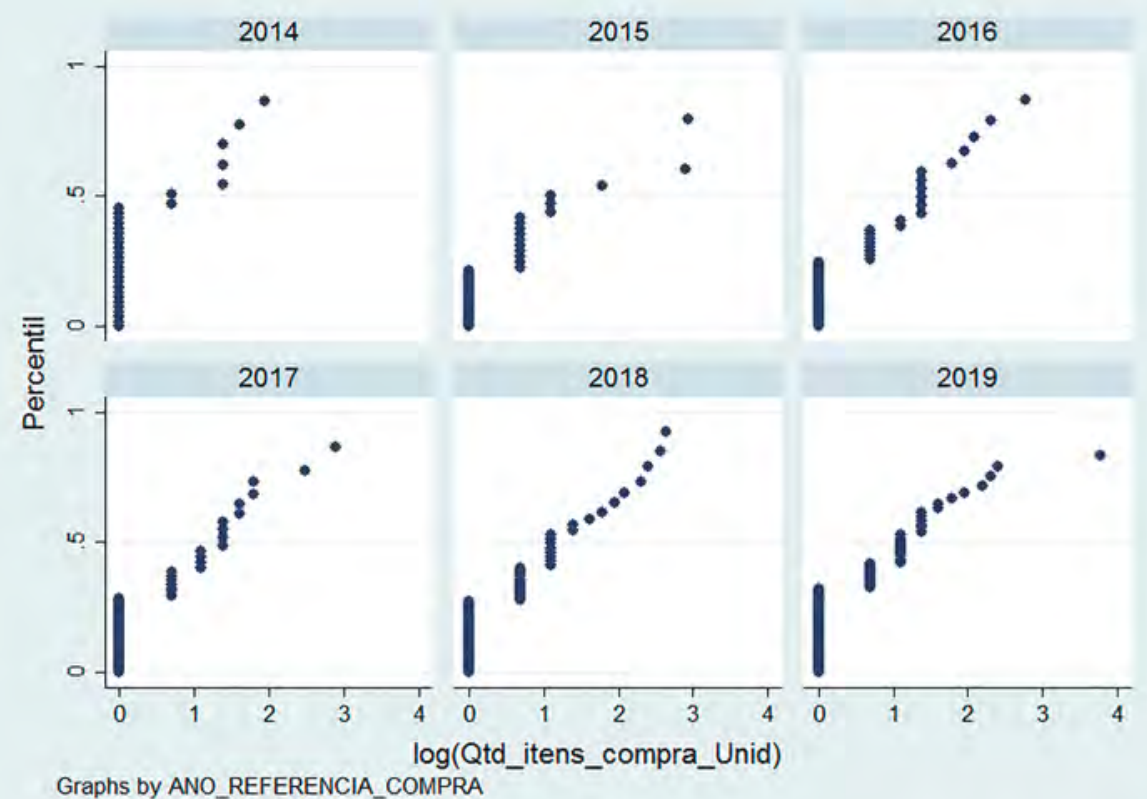

Classe 18540 - Artigos de papel para higiene

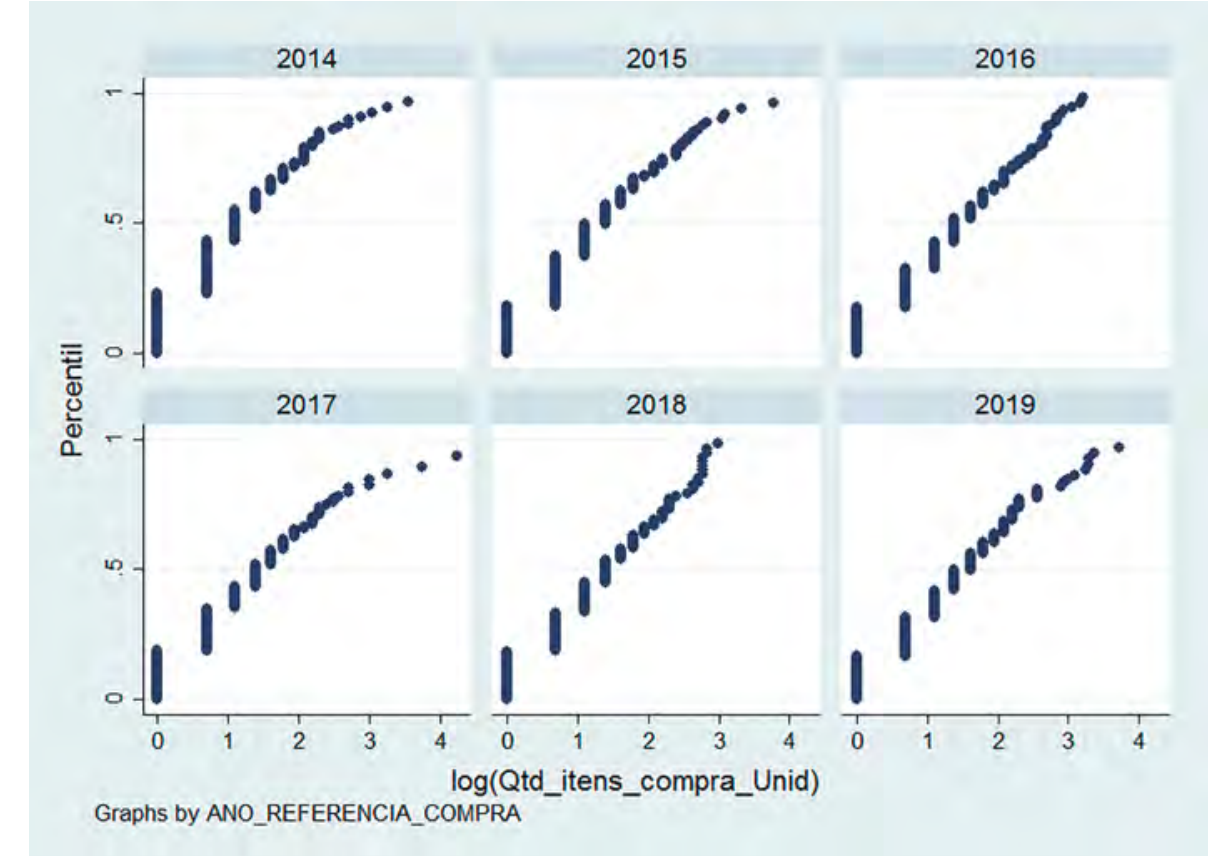

Graphs by ANO REFERENCIA COMPRA 
FIGURA A.6

Distribuição acumulada de valor empenhado por unidade compradora, por unidades compradoras (2014-2019)

Classe 14240 - Equipamento para segurança e salvamento

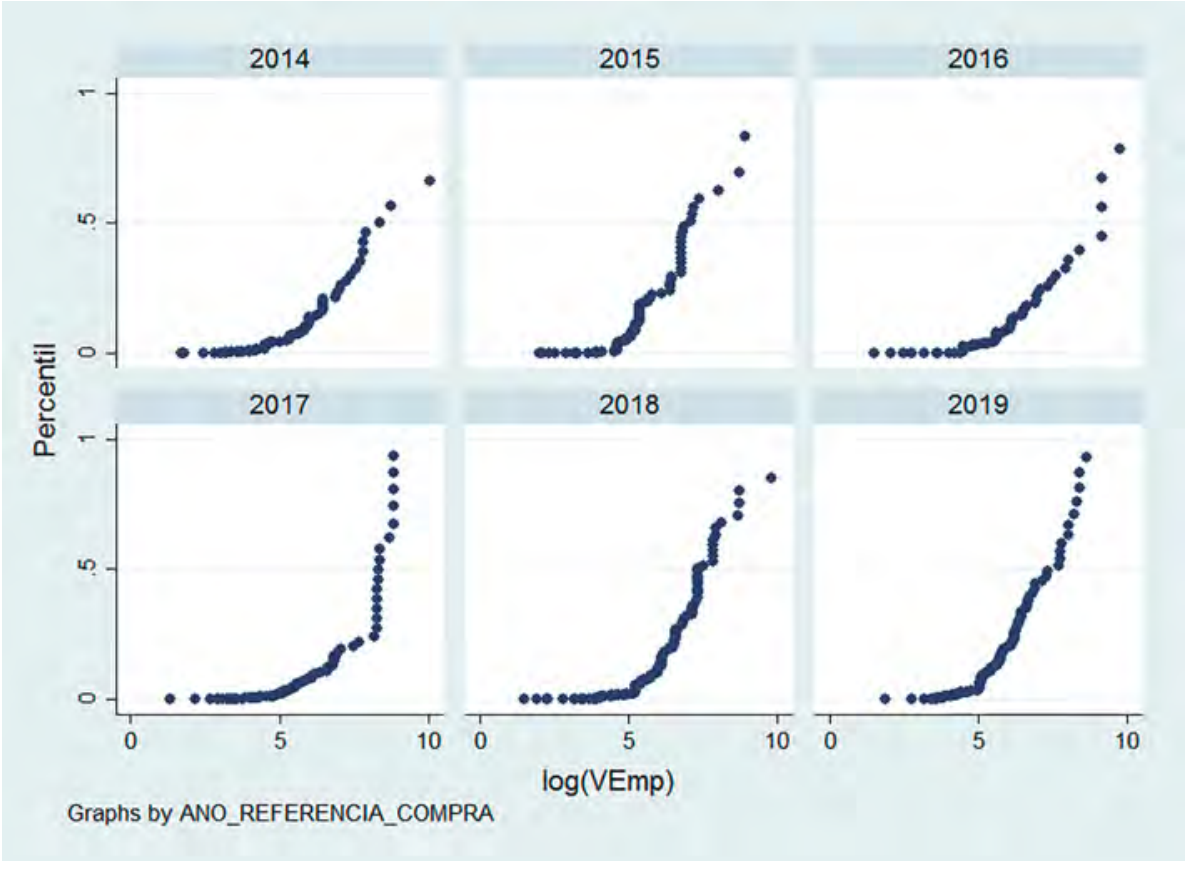

Classe 16505 - Drogas e medicamentos

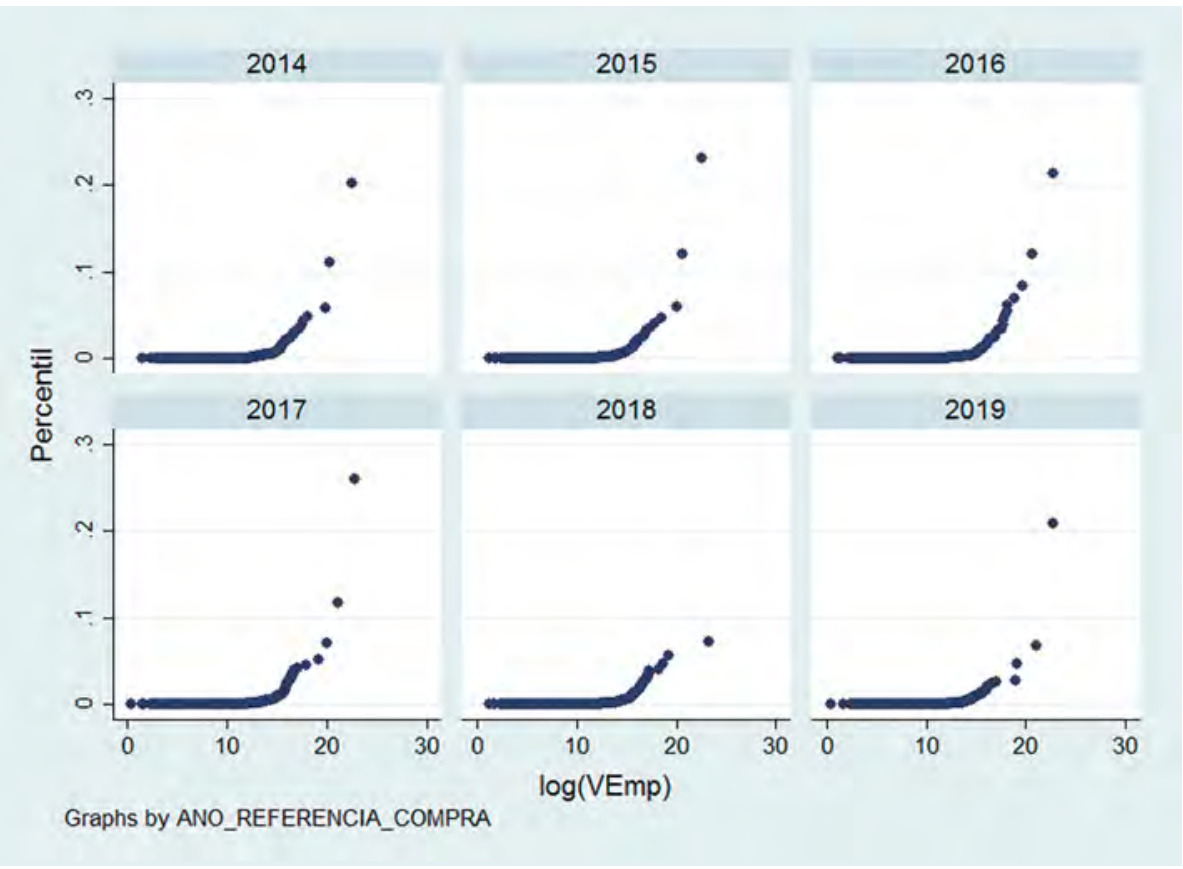


Classe 16515 - Instrumentos, equipamentos e suprimentos médicos e cirúrgicos

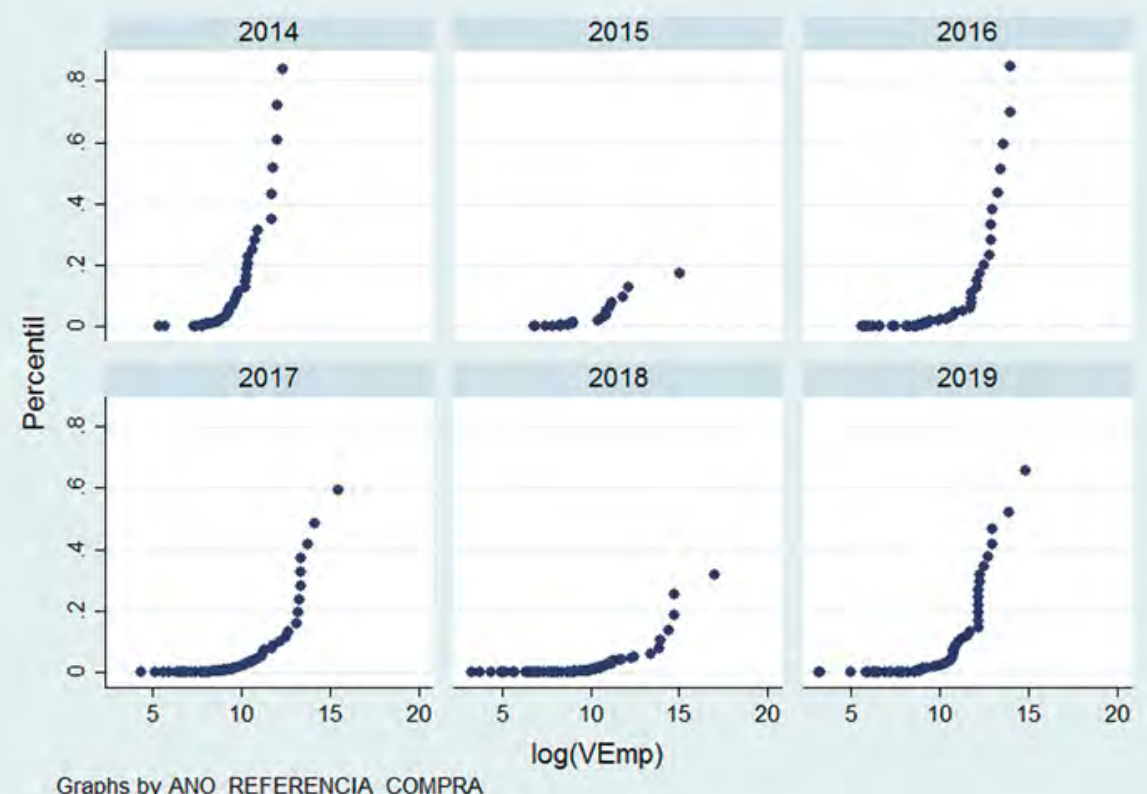

Classe 16532 - Vestuário hospitalar e cirúrgico e itens correlatos de finalidades especiais

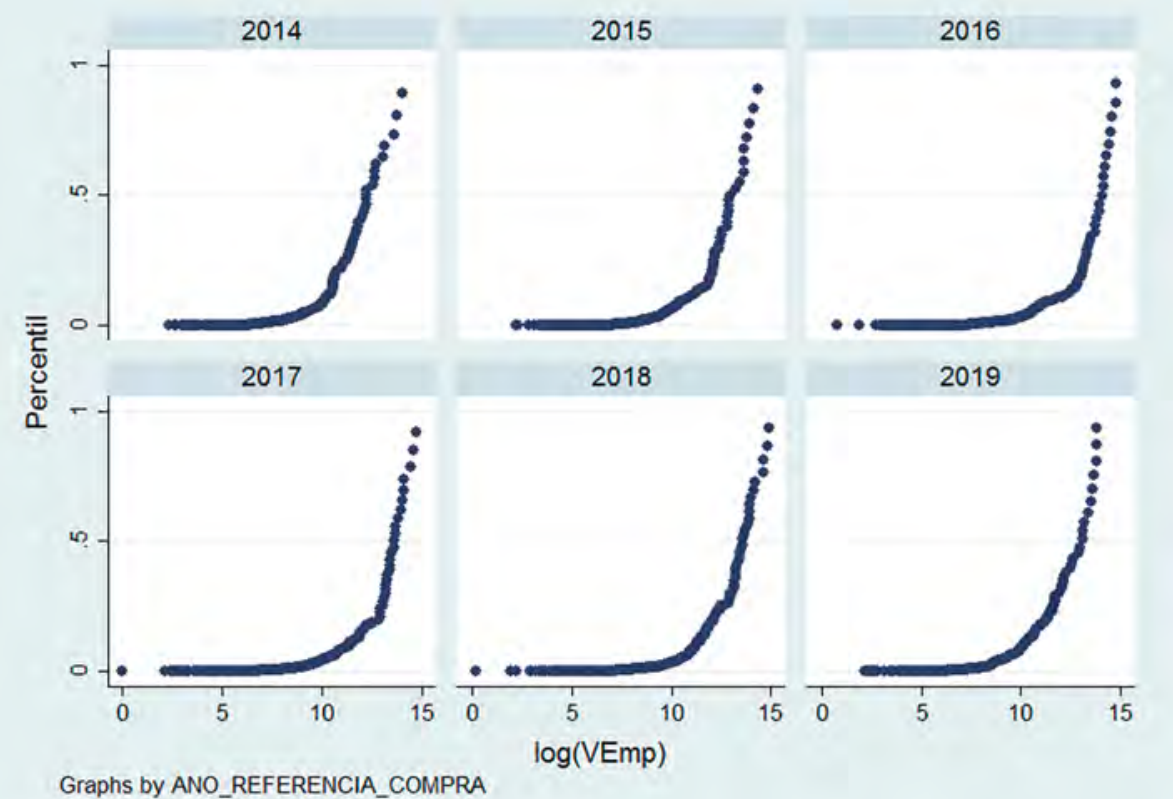


Classe 16810 - Produtos químicos

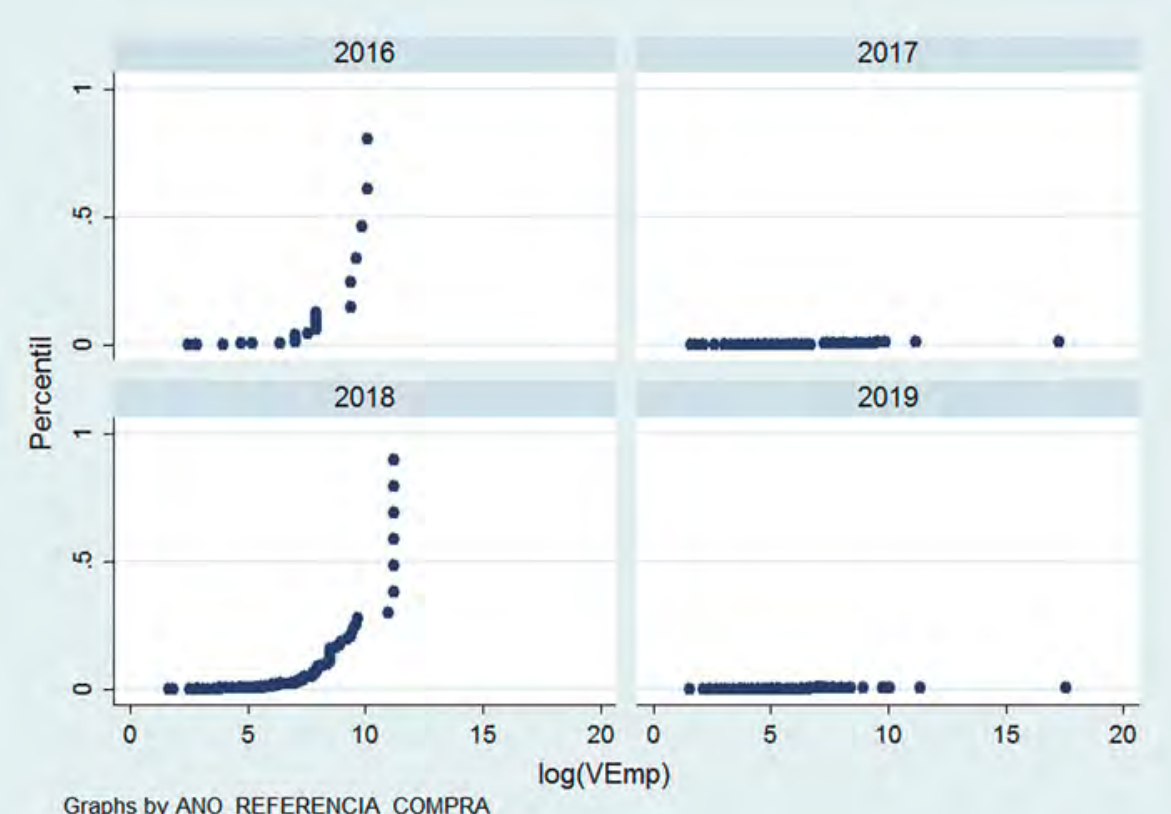

Graphs by ANO_REFERENCIA_COMPRA

Classe 18105 - Sacos e bolsas

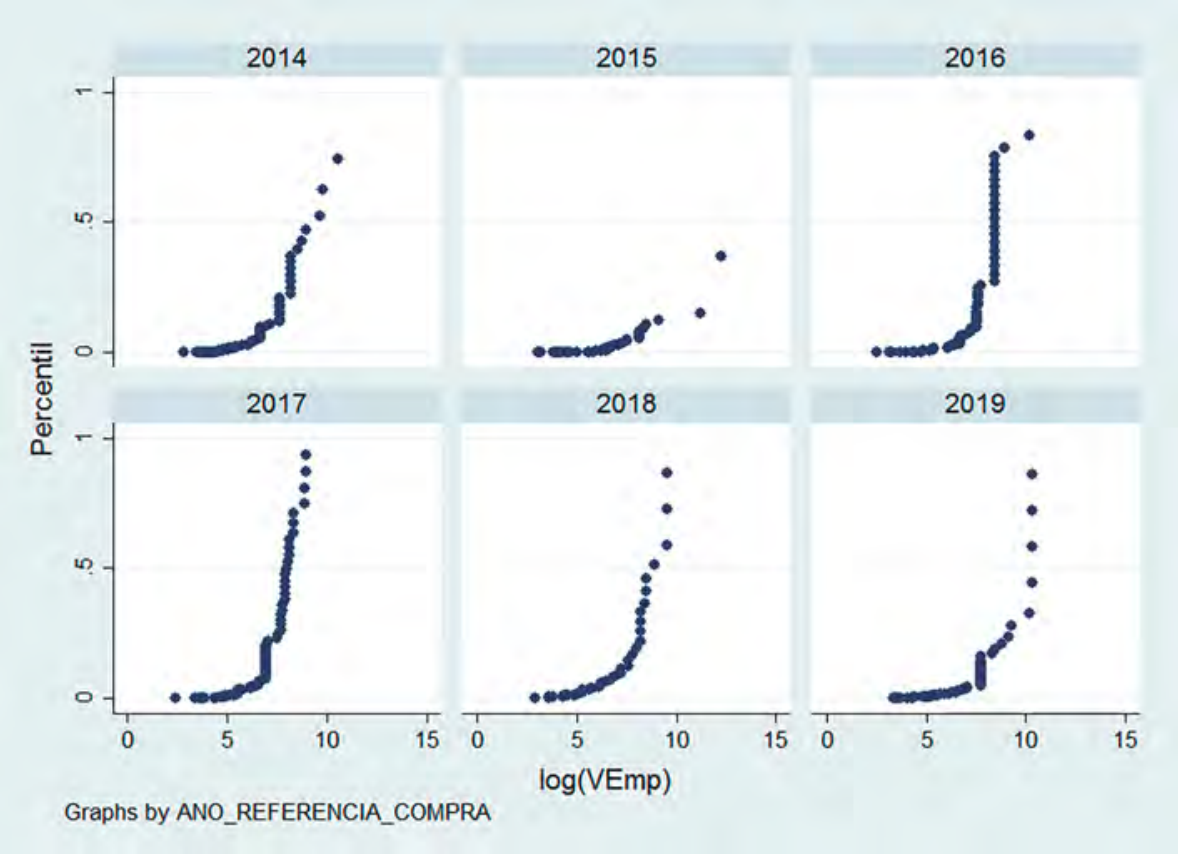


Classe 18520 - Sabonetes, artigos para barbear e dentifrícios

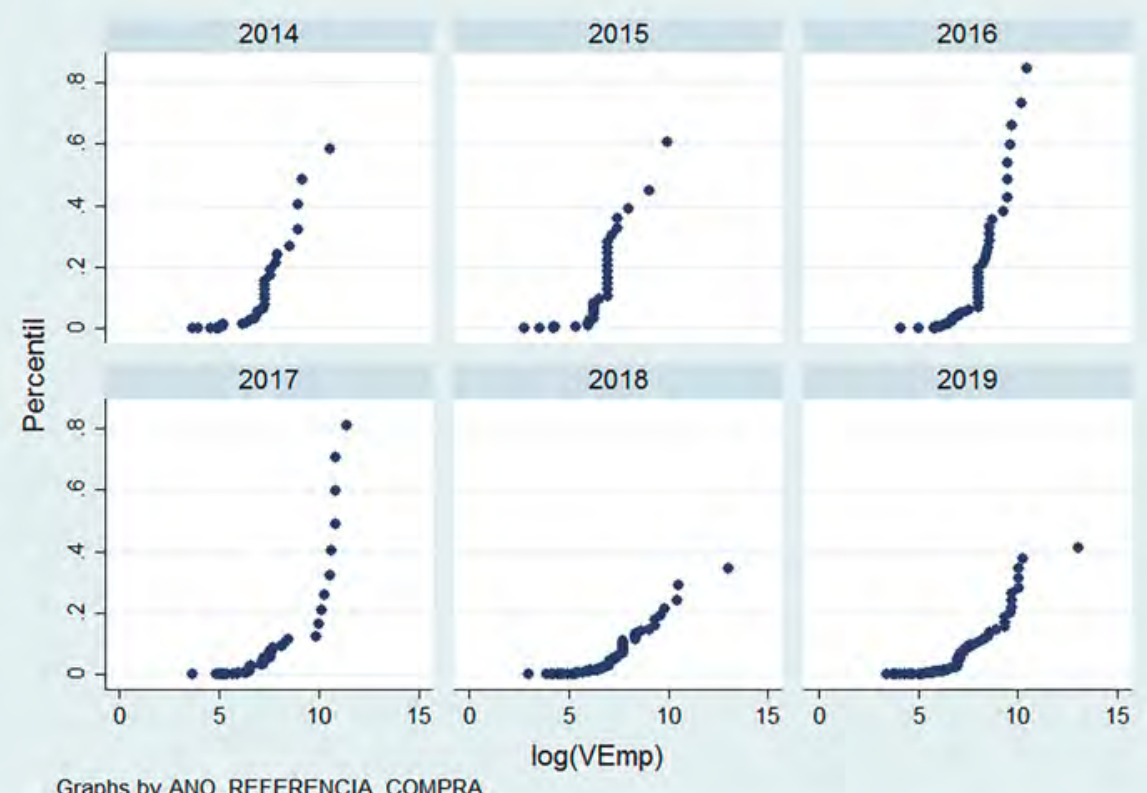

Classe 18540 - Artigos de papel para higiene

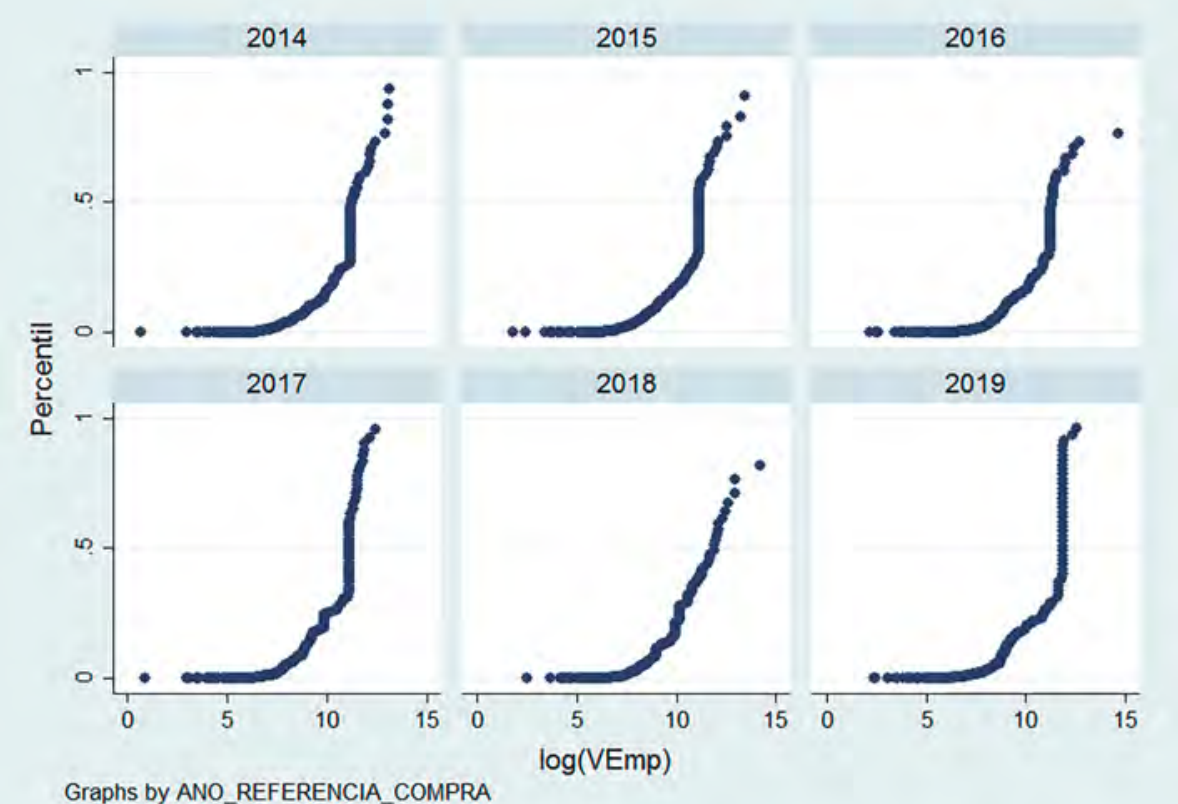


FIGURA A. 7

Distribuição acumulada do valor homologado de acordo com a unidade responsável pela compra

Classe 14240 - Equipamento para segurança e salvamento

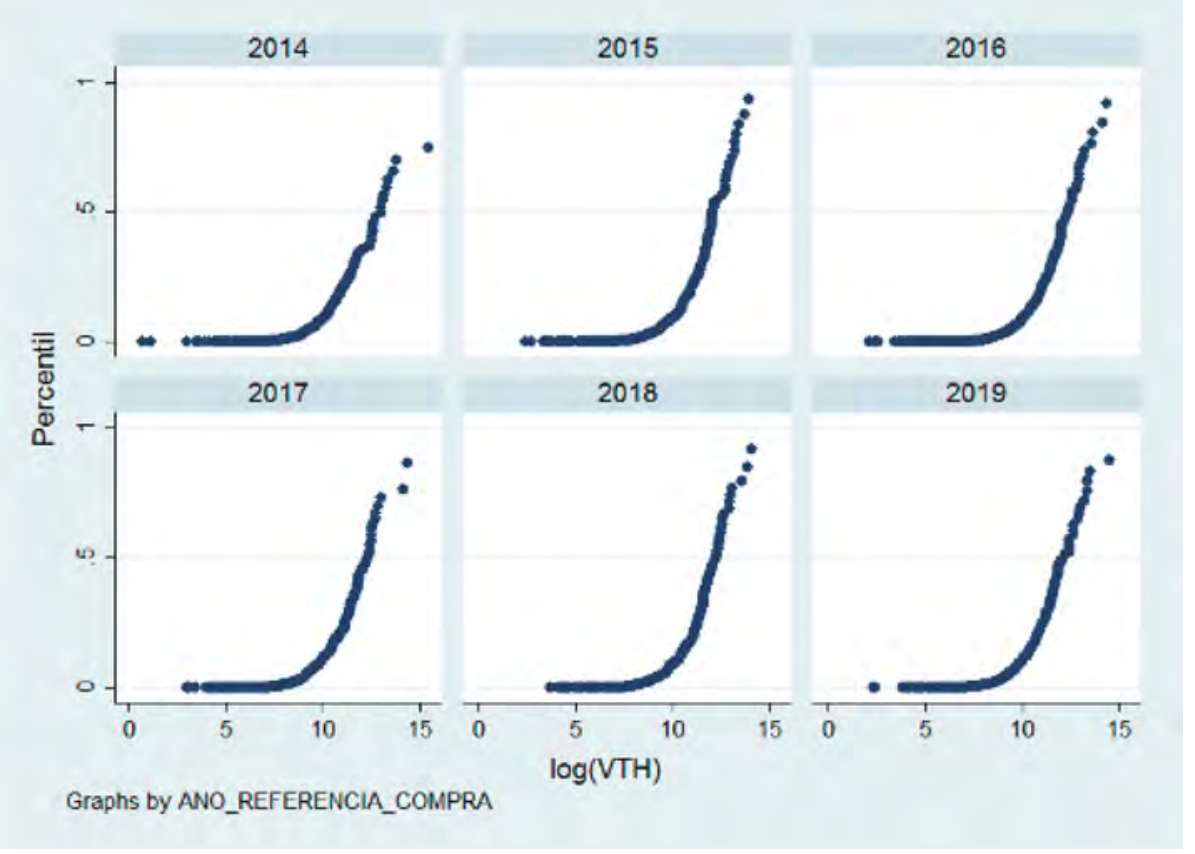

Classe 16505 - Drogas e medicamentos

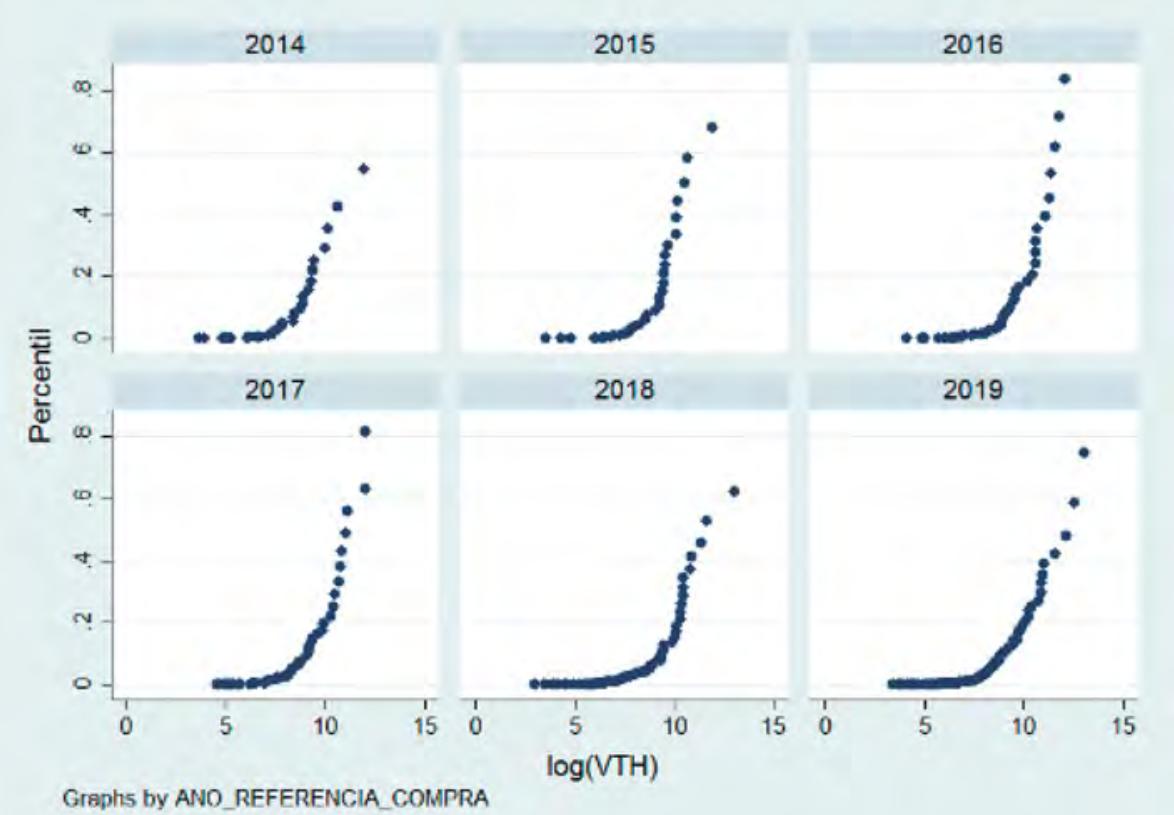


Classe 16515 - Instrumentos, equipamentos e suprimentos médicos e cirúrgicos

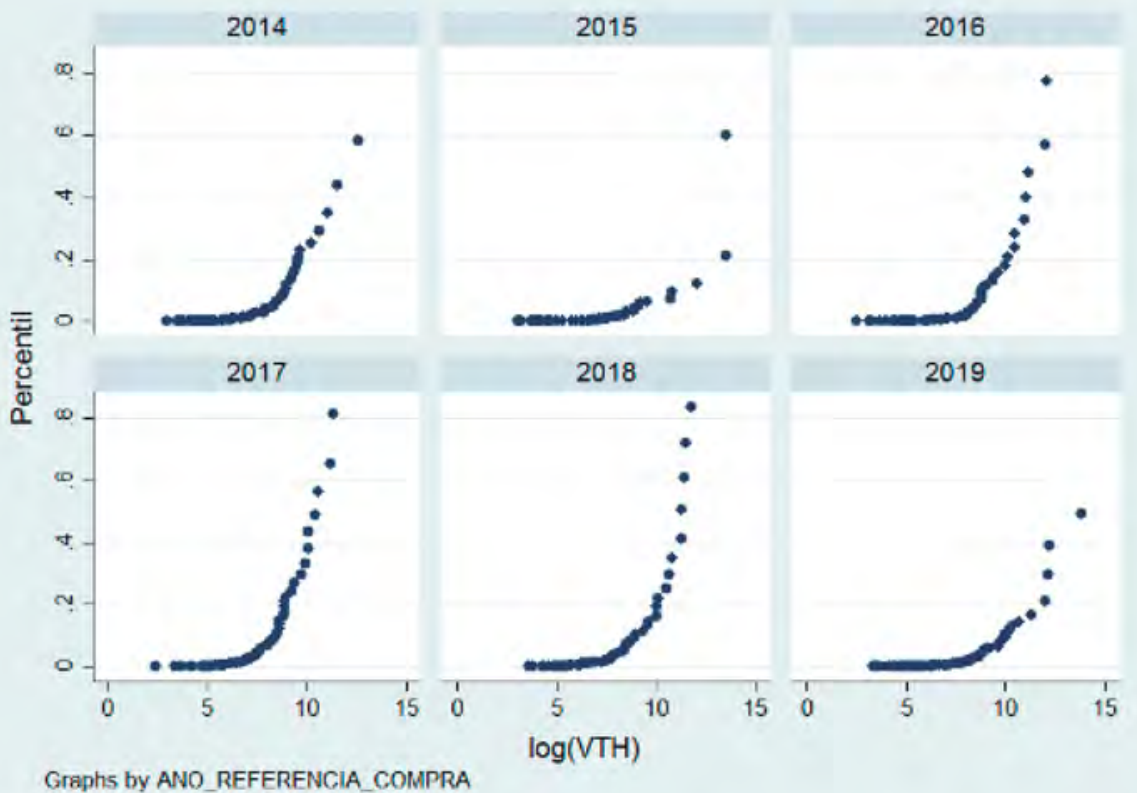

Classe 16532 - Vestuário hospitalar e cirúrgico e itens correlatos de finalidades especiais

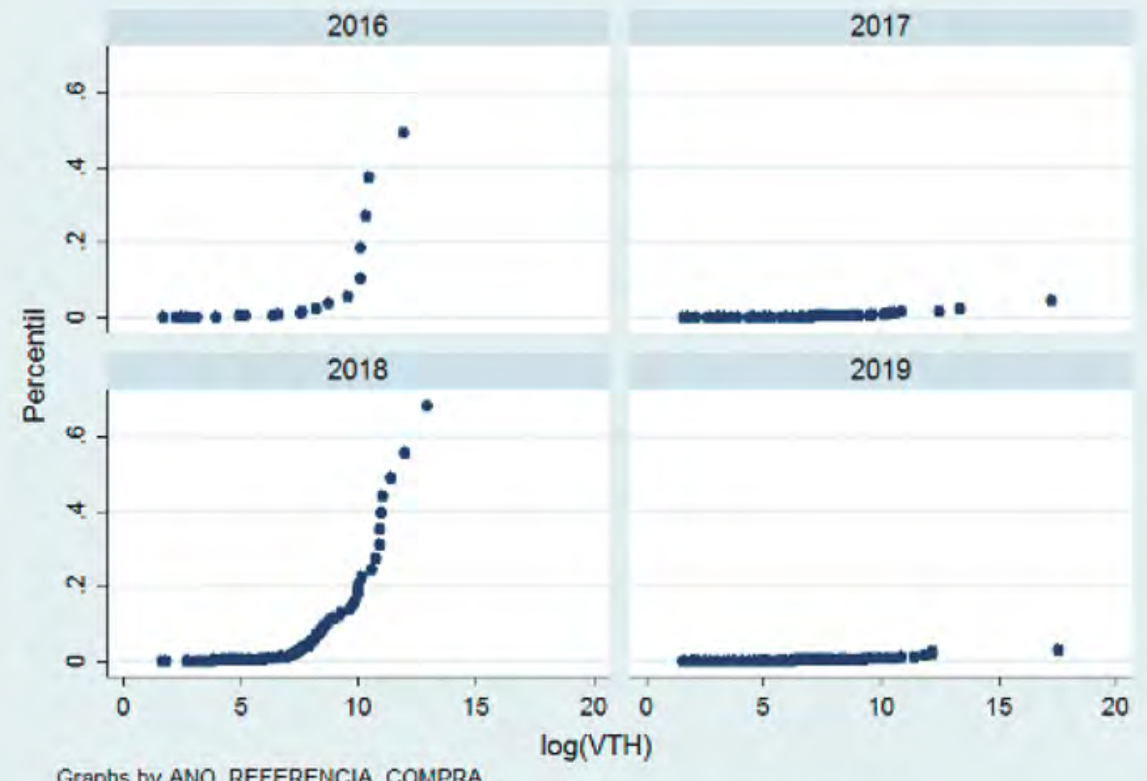

Graphs by ANO REFERENCIA COMPRA 
Classe 16810 - Produtos químicos

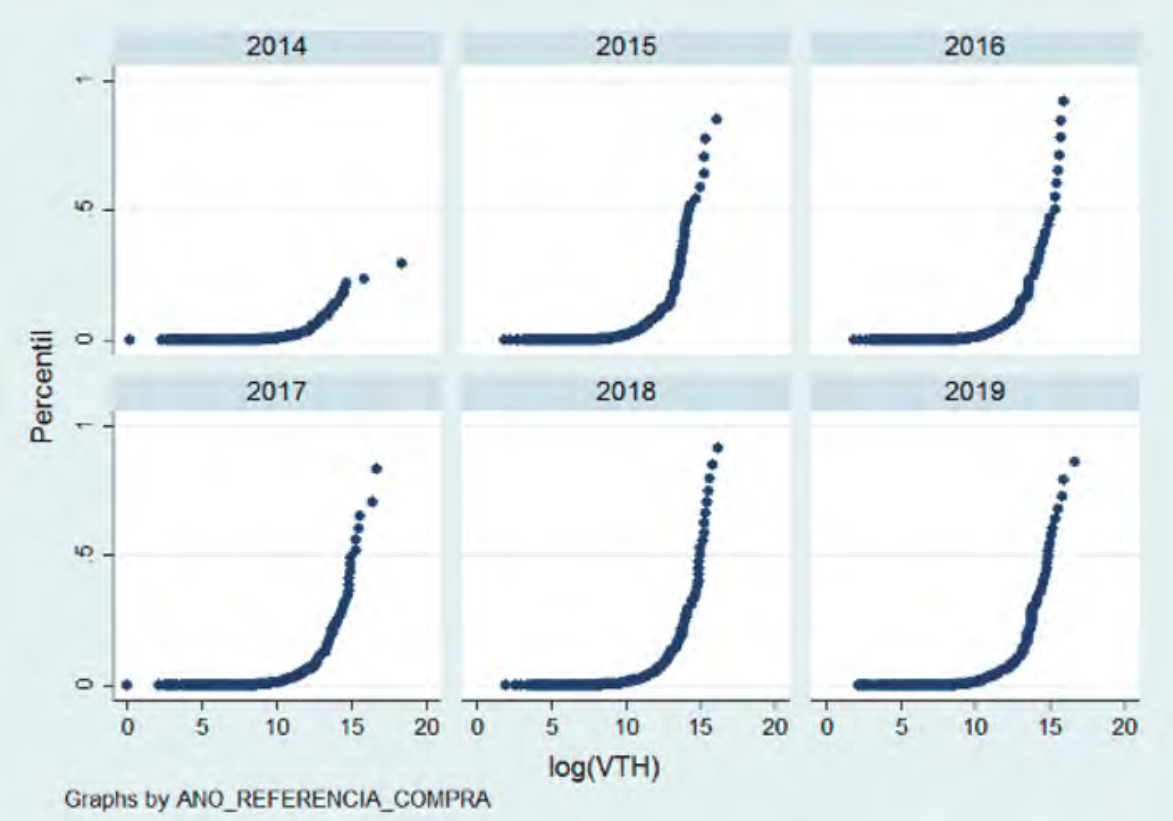

Classe 16505 - Drogas e medicamentos

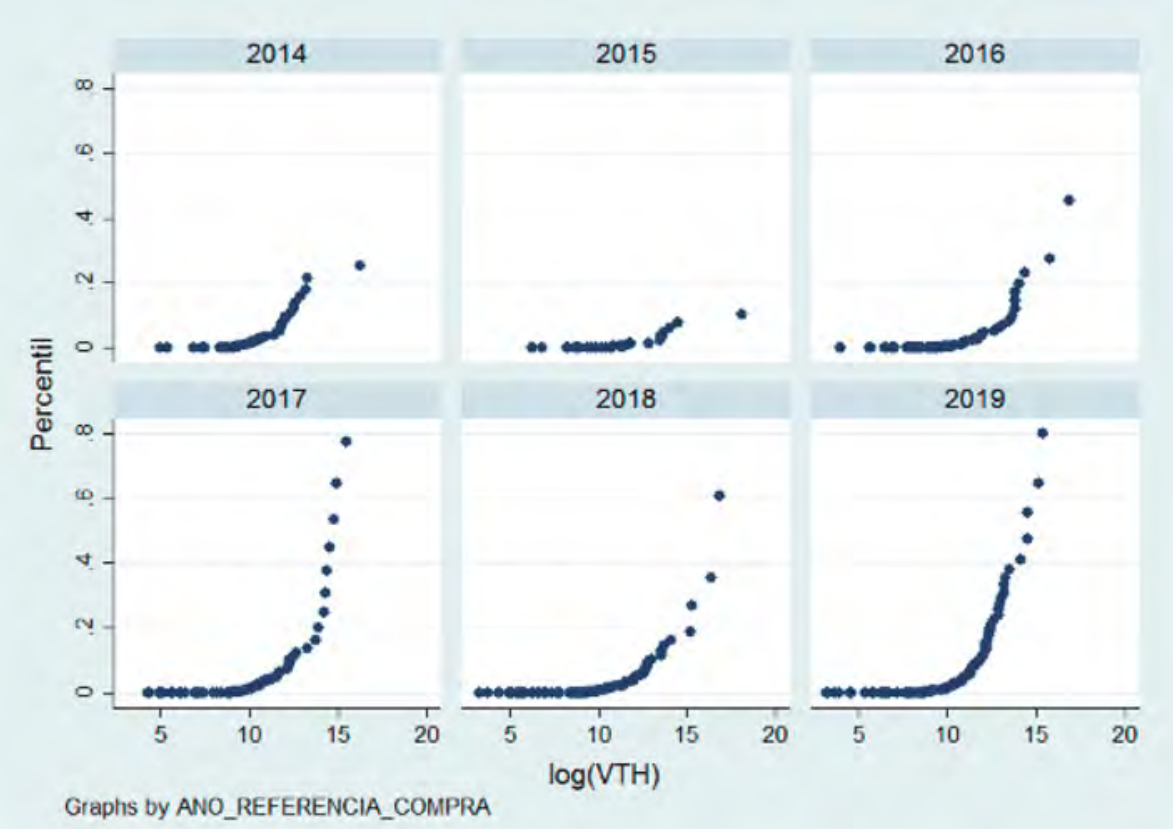


Texto para

Discussão

Classe 18520 - Sabonetes, artigos para barbear e dentifrícios
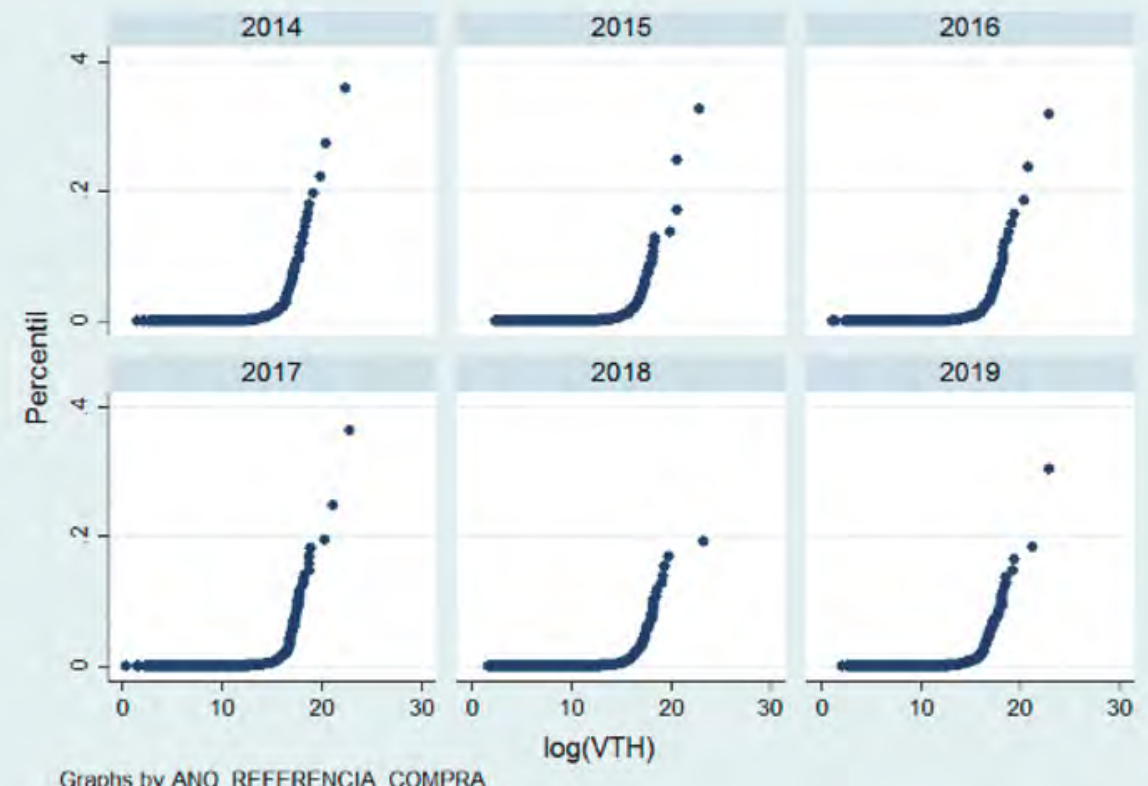

Graphs by ANO_REFERENCIA_COMPRA

Classe 18540 - Artigos de papel para higiene
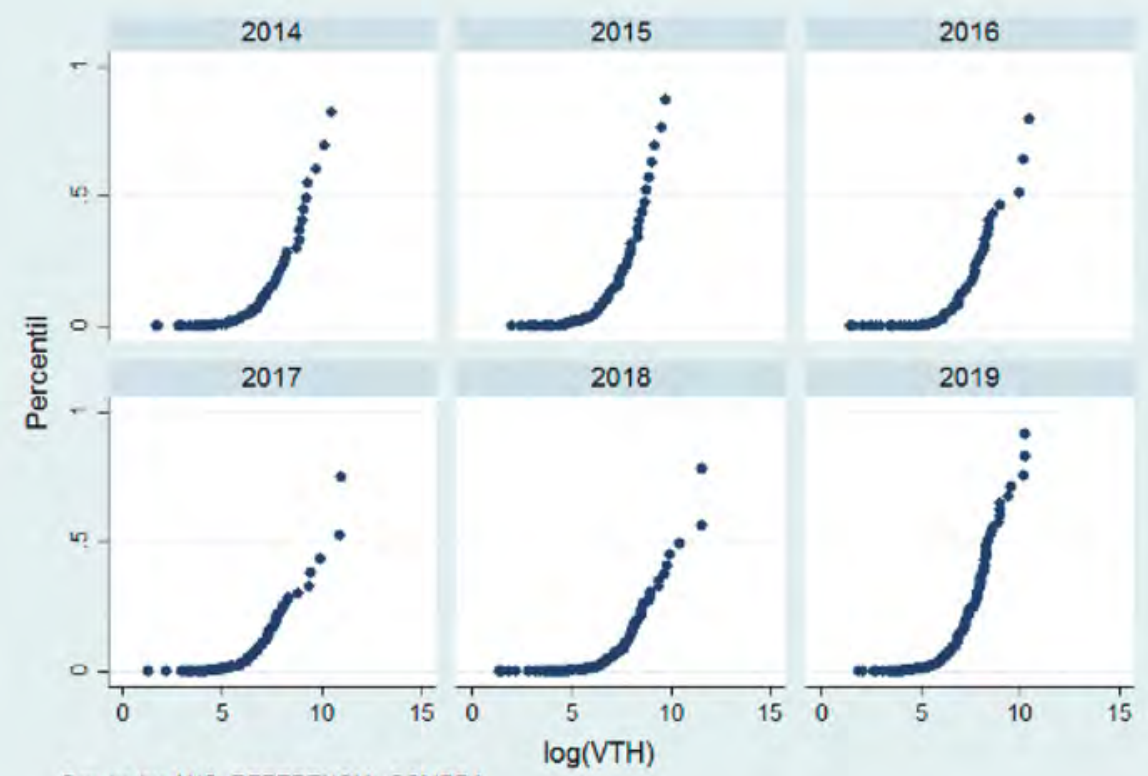

Graphs by ANO_REFERENCIA_COMPRA 


\section{ANEXO A}

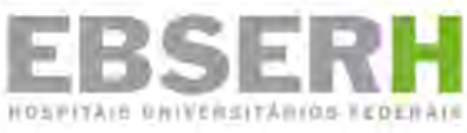

DOS ACORDOS-MARCOS

Art. XXX As unidades encarregadas de compras centralizadas poderão realizar, de ofício ou a pedido de uma ou mais entidades compradoras atendidas, licitação para firmar Acordo-Marco para compra de bens e serviços.

§ 190 Acordo-Marco é um acordo entre uma ou mais unidades contratantes e um ou mais fornecedores, cujo objeto é a fixação dos termos dos contratos a serem celebrados durante um determinado periodo.

$\S 2$ Cabe à Administração Central da Ebserh conduzir compras centralizadas para firmar AcordosMarcos ou autorizar a condução de etapas do processo de compras centralizadas por unidade hospitalar pertencente à estatal.

Art. XXX O Acordo-Marco firmado é de uso obrigatório pelas unidades atendidas, que deverão interagir diretamente com os fornecedores credenciados, conforme dinâmica de interação previamente pactuada.

Parágrafo único. As unidades atendidas por Acordos-Marcos somente podem efetuar compras por outras técnicas de contratação caso, por conta própria, obtenham condições locais mais vantajosas, situação sobre a qual deverá informar a respectiva unidade centralizadora, que adotará medidas para incorporar tais condições ao Acordo-Marco.

Art. XXX Os Acordos-Marcos devem preferencialmente gerar mercados eletrônicos de compras, contendo lista de bens e/ou serviços e suas correspondentes condições de contratação, previamente licitadas e adjudicadas pela Administração, através de Sistema de Informação, disponiveis para as unidades compradoras.

\section{Seção I}

Mecanismo de operação

Art. XXX As unidades centralizadoras de compras poderão realizar processos para firmar AcordosMarcos considerando, entre outros elementos, os Planos Anuais de Compra das entidades compradoras atendidas, bem como estudos de demandas mais comuns e padronizáveis.

Art. XXX As entidades compradoras podem solicitar à respectiva centralizadora a realização de um Acordo-Marco para objeto ou conjunto de objetos específicos, ficando a cargo da centralizadora a avaliação de oportunidade e conveniência de atender a demanda.

Art. XXX O Acordo-Marco vigentes será traduzido em um Catálogo, que conterá uma descrição dos bens e serviços oferecidos, suas condições de contratação e a identificação dos fornecedores credenciados. 


\section{EBSERH}

$\S 10$ Cada unidade compradora atendida será obrigada a consultar o Catálogo antes de realizar procedimento de licitação ou contratação direta.

$\S$ 2ㅇ Se o Catálogo contiver o bem e/ou serviço pretendido, a unidade compradora deverá adquirilo emitindo diretamente um pedido de compra ao respectivo fornecedor, a menos que obtenha diretamente condiçöes mais vantajosas, caso em que denunciará o Acordo-Marco vigente, nos termos do artigo XXX deste Regulamento.

Art. XXX Os pedidos de compra emitidos sob o Catálogo devem obedecer às condições e benefícios acordados no Acordo-Marco e serão emitidos através do Sistema de Informação.

Art. XXX A licitação dos Acordos-Marcos poderá prescindir, fundamentalmente, de garantias contratuais.

Art. XXX No caso de aquisições por meio de um Acordo-Marco maior que R\$50.000,00, regulamentado no artigo a seguir, as entidades deverão solicitar proposta aos fornecedores credenciados, por meio de procedimento de Grandes Compras, exigindo garantias.

\section{Seção II}

\section{Grandes Compras}

Art. XXX Nas aquisições acima de $\mathrm{R} \$ 50.000,00$, chamadas de Grandes Compras, as unidades devem comunicar, através do Sistema, a intenção de compra a todos os fornecedores selecionados na respectiva categoria do Acordo-Marco.

§ 1 으 A intenção de compra incluirá as condições especificas de fornecimento pretendidas, concedendo prazo razoável para a apresentação de ofertas, que não pode ser inferior a 5 dias úteis a partir da data de publicação.

§ 20 A intenção de compra indicará, no mínimo, a data da decisão de compra, os requisitos específicos da demanda, as condições e os critérios de entrega e os pesos aplicáveis à avaliação das ofertas.

§ 3 A unidade deve selecionar a oferta mais conveniente de acordo com o resultado da tabela comparativa, que deve ser feita com base nos critérios de avaliação e ponderações definidos na comunicação da intenção de compra, devendo a tabela ser anexada à ordem de compra emitida e servir de base para a aprovação da contratação.

Art. XXX As propostas recebidas no âmbito de um procedimento de Grandes Compras serão avaliadas de acordo com os critérios e pesos definidos com base no processo de licitação do AcordoMarco correspondente, sempre que aplicável.

Parágrafo único. A licitação do respectivo Acordo-Marco pode estabelecer critérios especiais de avaliação para Grandes Compras. 


\section{EBSERH}

Art. XXX Os fornecedores participantes do Acordo-Marco são obrigados a apresentarem propostas nos procedimentos de Grandes Compras, respeitado o preço máximo ofertado no procedimento de seleção dos fornecedores.

Art. XXX A unidade compradora pode deixar de usar o procedimento de Grandes Compras em casos de emergência, urgência imprevista, determinada por uma resolução fundada pelo chefe da entidade, sem prejuízo das disposições especiais para casos de terremotos e catástrofes contidas na legislação.

\section{Seção II}

\section{Condições locais mais vantajosas}

Art. XXX A unidade contratante que obtiver condiçöes locais mais vantajosas em relação ao catálogo deverá informar a unidade centralizadora que gerencia o Acordo-Marco.

$\S 10$ As condições mais vantajosas devem se referir a situações objetivas, demonstráveis e sustentáveis para a unidade, como entrega, condições de entrega, garantias, qualidade do objeto e melhor custo/benefício.

$\S 2$ - As condições podem ser verificadas por intermédio de vários mecanismos diferentes, como: processos de consulta ao mercado, publicidade, listas de preços ou catálogos públicos, entre outros.

Art. XXX Caso a unidade contratante identifique condições locais mais vantajosas, poderá realizar processo de compra de acordo com outras regras licitatórias, mantendo o respectivo registro para revisão e controle futuros.

Parágrafo único. A unidade centralizadora correspondente poderá exigir a documentação comprobatória, afim de avaliar se as condições justificam alteração do Acordo-Marco vigente.

\section{Seção II}

\section{Formalizaçăo dos Acordos-Marcos}

Art. XXX O processo de seleção de fornecedor para credenciar o fornecedor de um Acordo-Marco será realizado de acordo com este Regulamento, podendo ser empreendido por intermédio de licitação ou de contratação direta, conforme o caso.

Parágrafo único. Os preços ofertados pelos licitantes durante a etapa de seleção do fornecedor serão considerados preços máximos. 
Art. XXX O edital para Acordo-Marco deve estabelecer os critérios de avaliação que a Administração considera relevantes para o contrato especifico e, entre outras coisas, deve levar em conta o preço, as condições comerciais, a experiência dos concorrentes, a qualidade técnica, as considerações ambientais e o frete.

Art. XXX Os Acordos-Marcos vigentes serão formalizados por intermédio de Contratos-Marco, compreendidos como contratos centralizados com execução descentralizada.

$\S 100$ prazo de vigência dos Contratos-Marco será de até quatro anos.

$\S 2$ Os Contratos-Marco devem regulamentar os direitos e as obrigações das partes, assim como orientar como a unidade centralizadora manterá a supervisão adequada dos Acordos-Marcos.

§ 3ำ A formalização da execução descentralizada poderá ocorrer por intermédio de assinatura de contratos, por emissão de notas de empenho ou por outro meio igualmente válido.

Art. XXX As falhas no cumprimento de suas obrigações sujeitam os fornecedores às penalidades descritas neste Regulamento e no Contrato-Marco.

$\S 1^{\circ}$ A ausência de apresentação de propostas nas intenções de compra durante os procedimentos de Grandes Compras implica em apuração de irregularidade na execução contratual.

$\S 20$ As rescisões antecipadas de Contratos-Marco devem ser deliberadas pela unidade centralizadora e são motivadas por falhas no cumprimento de suas obrigações.

$\S 3$ No caso de rescisões de Contratos-Marco, a unidade centralizadora deve avaliar a decisão de manutenção dos Contratos-Marco restantes no cada Acordo-Marco, de forma a manter a competitividade da sistemática pela existência de um número adequado de fornecedores. 
Ipea - Instituto de Pesquisa Econômica Aplicada

\title{
EDITORIAL
}

\section{Coordenação}

Reginaldo da Silva Domingos

Assistente de Coordenação

Rafael Augusto Ferreira Cardoso

\section{Supervisão}

Camilla de Miranda Mariath Gomes

Everson da Silva Moura

\section{Editoração}

Aeromilson Trajano de Mesquita

Bernar José Vieira

Cristiano Ferreira de Araújo

Danilo Leite de Macedo Tavares

Herllyson da Silva Souza

Jeovah Herculano Szervinsk Junior

Leonardo Hideki Higa

\section{Capa}

Danielle de Oliveira Ayres

Flaviane Dias de Sant'ana

\section{Projeto Gráfico}

Renato Rodrigues Bueno

The manuscripts in languages other than Portuguese published herein have not been proofread.

\author{
Livraria Ipea \\ SBS - Quadra 1 - Bloco J - Ed. BNDES, Térreo \\ 70076-900 - Brasília - DF \\ Tel.: (61) 2026-5336 \\ Correio eletrônico: livraria@ipea.gov.br
}



Composto em adobe garamond pro 12/16 (texto) Frutiger 67 bold condensed (títulos, gráficos e tabelas) Brasília-DF 



\section{Missão do Ipea}

Aprimorar as políticas públicas essenciais ao desenvolvimento brasileiro por meio da produção e disseminação de conhecimentos e da assessoria ao Estado nas suas decisões estratégicas.

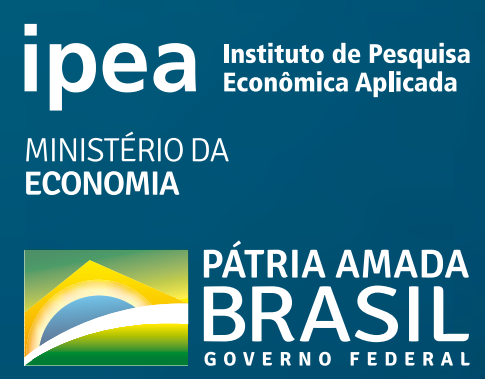

